\title{
$1^{0}$ simpósio de pesquisa técnico-científica do Mestrado Profissional em Design da Univille: relatos
}

ORGANIZAÇÃO:

João Eduardo Chagas Sobral

Marli Teresinha Everling

Adriane Shibata Santos

Anna Luiza Moraes de Sá Cavalcanti

Elenir Carmen Morgenstern

Victor Rafael Laurenciano Aguiar

Fernando Pereira Pruner

\section{Blucher Open Access}




\section{0 simpósio de pesquisa técnico-científica do Mestrado Profissional em Design da Univille: relatos}

ORGANIZAÇÃO:

João Eduardo Chagas Sobral

Marli Teresinha Everling

Adriane Shibata Santos

Anna Luiza Moraes de Sá Cavalcanti

Elenir Carmen Morgenstern

Victor Rafael Laurenciano Aguiar

Fernando Pereira Pruner 
$1{ }^{\circ}$ simpósio de pesquisa técnico-científica do Mestrado Profissional em Design da Univille: relatos

(c) 2016 João Eduardo Chagas Sobral, Marli Teresinha Everling, Adriane Shibata Santos, Anna Luiza Moraes de Sá Cavalcanti, Elenir Carmen Morgenstern, Victor Rafael Laurenciano Aguiar, Fernando Pereira Pruner (organizadores)

\section{Editora Edgard Blücher Ltda.}

\section{Diagramação}

Ricardo Steiner

\section{Projeto gráfico e capa}

\section{Ricardo Steiner}

com base na identidade visual desenvolvida por Haro Schulenburg para o Primeiro Simpósio de Pesquisa TécnicoCientífica do Mestrado Profissional em Design da Univille.

\section{Blucher}

Dados Internacionais de Catalogação na Publicação (CIP) Angélica llacqua CRB-8/7057

Rua Pedroso Alvarenga, $1245,4^{\circ}$ andar 04531-934 - São Paulo - SP - Brasil

Tel 5511 3078-5366

\section{contato@blucher.com.br} www.blucher.com.br

Segundo Novo Acordo Ortográfico, conforme 5. ed. do Vocabulário Ortográfico da Língua Portuguesa, Academia Brasileira de Letras, março de 2009.

É proibida a reprodução total ou parcial por quaisquer meios, sem autorização escrita da Editora.

Todos os direitos reservados pela Editora Edgard Blücher Ltda.
Simpósio de pesquisa técnico-científica do mestrado profissional em design da Univille (1. : 2015 : Santa Catarina)

Relatos [livro eletrônico] / Univille ; [organizado por João Eduardo Chagas Sobral... et al.]. - São Paulo : Blucher, 2016.

328 p. il. color. ; PDF.

Bibliografia

ISBN 978-85-8039-185-5 (e-book)

ISBN 978-85-8039-186-2 (impresso)

1. Desenho industrial 2. Desenho (Projetos) I. Título. II. Universidade da Região de Joinville. III. Sobral, João Eduardo Chagas. 


\section{Prefácio}

A publicação dos resultados da Primeira Edição do Simpósio de Pesquisa Técnico-Científica em Design da Univille tem por objetivo socializar conhecimentos gerados no Programa de Pós-Graduação em Design - PPGDesign, em conjunto com o setor produtivo e a comunidade em geral. A relevância desta produção está na elaboração e disseminação do conhecimento promovido pelas instituições envolvidas, em uma ação conjunta para valorizar o conhecimento aplicado, seja no campo técnico, seja no campo científico.

O evento, que originou a publicação, ocorreu em fevereiro de 2015 como uma iniciativa inédita, pois reuniu em uma mesma semana, as defesas dos trabalhos de conclusão, mesas redondas com temas voltados ao conhecimento produzido, além de um ciclo de palestras. Configurou-se assim em importante estratégia para a formação de redes de pesquisa, além da integração entre empresas e academia; ações estas que se desenham, também, como prioridade em um Mestrado Profissional, comprometido em responder à problemas do cenário industrial, social e econômico no contexto regional.

Uma das funções dos mestrados profissionais é estimular a formação de mestres habilitados a desenvolver atividades e trabalhos técnicocientíficos em temas de interesse público. Os trabalhos de conclusão de curso podem ser apresentados em diferentes formatos, incluindo dissertação, patente, registro de propriedade intelectual, projeto 
técnico, publicação tecnológica; desenvolvimento de materiais instrucionais, produtos, processos e técnicas, dentre outros.

A partir destas observações, o PPGDesign da Univille, em sua proposta de criação (2012)' considera que o "projeto final poderá consistir em dissertação, projeto técnico específico, estudo de caso, propriedade intelectual, patentes, depósito de patentes, projeto de produto ou serviço, trabalho científico de pesquisa em design, desenvolvimento de instrumentos, equipamentos e protótipos".

Esta iniciativa do PPGDesign da Univille vem ao encontro da procura por caminhos que possam responder aos grandes desafios com os quais os mestrados profissionais se defrontam. Desafios que vão desde o fortalecimento de canais de diálogo e colaboração mútua entre empresas e universidades, até o próprio estranhamento da comunidade acadêmica em relação ao formato dos trabalhos de conclusão de curso. No entanto, o PPGDesign tem enfrentado esses novos caminhos os vendo como oportunidade para o fortalecimento da produção técnico-científica significativa para o conjunto da sociedade, contribuindo para a constituição de um círculo virtuoso entre academia e setor produtivo, a exemplo do que ocorre com os programas de pós-graduação de outros países, que possuem forte compromisso com a conversão do conhecimento em benefícios para a sociedade.

Por fim, reafirma-se que esta obra compila resultados derivados dos primeiros trabalhos de conclusão de curso do Mestrado Profissional em Design da Univille, além das reflexões dos professores convidados

\footnotetext{
${ }^{1}$ UNIVILLE. APCN do Curso de Mestrado Profissional em Design. Código da Proposta: 8123. Joinville, Maio de 2012.
} 
para as bancas, mesas redondas e palestras. O arcabouço teórico que estimulou os debates sobre a estreita relação entre teoria científica e práticas profissionais voltadas à sociedade, apresentado nesse trabalho, caracteriza-se como um esforço conjunto do PPGDesign da Univille em direção à disseminação do conhecimento técnico-científico. 


\section{Sumário}

Introdução

Vinte anos da pós-graduação em Design no Brasil: novos rumos

Luiz Antonio Luzio Coelho

Criatividade e inovação

Ligia Maria Sampaio de Medeiros

Design de produto médico-hospitalar: projeto e desenho coletor de urina sistema fechado para perna Andréia Bordini de Brito | Uda Souza Fialho| José Fialho de Oliveira Júnior

Design industrial na Whirlpool Latin America: filosofia e resultados

Rota segura para dias de inundações: desenvolvimento de elementos visuais para auxiliar na locomoção, alertas e localização da população Jean Fabyano Andrighi | Virginia Grace Barros

Design de superfície: a valorização do Museu Nacional do Mar por meio da criação de artefatos

Design \& embalagens: um estudo de caso da indústria Itálica 


\section{A imersão em uma indústria joinvilense possibilitando um}

153 diagnóstico para a busca de uma nova atuação de mercado Larissa Angeoleti Schulenburg | Victor Rafael Laurenciano Aguiar

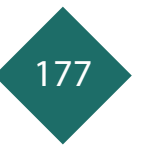

Diretrizes de design de interfaces para terceira idade: guia projetual para o desenvolvimento de interfaces em refrigeradores voltados ao público idoso

Victor Henrique Fagundes | Adriane Shibata Santos

\section{O protagonismo do design}

\section{5 e suas contribuições no terceiro setor}

Rosangela Canônica | Rita Inês Petrykowski Peixe | Adriane Shibata Santos

\section{Design de moda e artesanato:}

\section{9 uma relação social recíproca}

Rita de Cássia Rothbarth Lorenzi | Elenir Carmen Morgenstern

\section{Desenvolvimento de produtos a partir do reúso}

\section{9 de materiais metálicos descartados}

Sidnei Luiz Zamberlan | Anna Luiza Moraes de Sá Cavalcanti

Resíduos da construção civil em pequenas obras: uma análise sob a ótica do design

Mateus Szomorovszky | Anna Luiza Moraes de Sá Cavalcanti | Marli Teresinha

Everling

O processo criativo, a arquitetura e o design na vivência da

279 experiência Refúgio Criativo

Miguel Canãs Martins | Marli Teresinha Everling

\section{A linguagem visual e a percepção:}

\section{9 um estudo de caso em crianças}

Eloah Maria Oliveira Acauan | João Eduardo Chagas Sobral 


\section{Introdução}

A trajetória do Programa de Mestrado Profissional em Design da Univille inicia-se em 2013 com a intenção de preencher uma lacuna existente na capacitação profissional na área de Design de Produto e Serviços, em nível de mestrado na região norte de Santa Catarina. Caracterizada pelo diversificado e forte parque fabril da região, estende-se da agroindústria à indústria têxtil, da cerâmica à indústria metalmecânica, além de um crescente desenvolvimento no setor de serviços.

2015 foi um ano simbólico para o Programa devido ao fechamento do ciclo da primeira turma com a defesa dos trabalhos de conclusão de curso (TCC). Para celebrar esse momento, planejamos a Primeira Edição do Simpósio de Pesquisa Técnico-Científica do Mestrado em Design da Univille. Essa edição objetivou a socialização de conhecimentos técnico-científicos gerados na academia e no setor produtivo com a comunidade em geral, promovendo aproximações interinstitucionais (com o setor produtivo, terceiro setor e outras universidades) por meio de palestras, mesas-redondas e apresentação dos TCCs. 
Dentre os palestrantes destacamos a presença do Prof. Dr. Ricardo Triska (UFSC), Prof. Dr. Luiz Antônio Coelho (PUC-Rio), Prof. Dr. Alberto Cipiniuk (PUC-Rio), Prof. a Dra. Lígia Medeiros (ESDI/UFRJ), Prof.a Dra. Andreia Bordini (UFPEL), Prof. Msc. Fernando Pruner (Whirlpool Latin America). Este livro conta com a participação dos relatos da primeira turma do PPGDesign da Univille, bem como alguns artigos relacionados às palestras apresentadas no evento. Agradecemos ainda aos participantes das mesas-redondas, Prof. Dr. Carlos Sacchelli, Prof. Dr. Doalcei Ramos (UDESC), Prof. Dr. Eugênio Merino (UFSC), Prof. Dr. Guilherme Santa Rosa, Prof. a Dra. Marion Pozzi (UFRGS), pela sua contribuição como membros externos das bancas e sua disponibilidade em conversar com a audiência ao final da banca.

Destacamos que, devido a natureza do PPGDesign da Univille, que se configura como mestrado profissional, a primeira edição do Simpósio pretende ser reflexo do movimento docente e discente realizado na produção do conhecimento técnico-científico integrando o setor produtivo, o contexto sóciocultural e a academia. 



\section{Vinte anos da pós-graduação em Design no Brasil: novos rumos}

Luiz Antonio Luzio Coelho (Currículo Lattes)

\section{ESTE TRABALHO ESTÁ DIVIDIDO EM CINCO PARTES:}

1. Integração GRA e PÓS;

2. A pós-graduação em Design na PUC-Rio;

3. A importância da pesquisa no Design;

4. Precursores do desenvolvimento da formação dos cursos em Design;

5. O atual paradigma da pesquisa em Design: perspectivas de estudo.

O tempo deixa suas marcas e por meio destas conhecemos o percurso trilhado. Como é natural, essas marcas podem constituir o norte para se decidir o que é preciso fazer, vez que representam 
carências e desafios passados que apontam para o que está à frente. Desta forma, este texto busca trazer o contexto do Design no momento da criação do primeiro programa de pós-graduação no país, com algumas informações que marcaram tal experiência'. Não o queremos apenas a título de registro, mas como memória que possa constituir vetor para novas estratégias de desenvolvimento da área.

\section{GRA E PÓS: COMPETIR OU INTEGRAR?}

Quando se cria um programa de pós-graduação, considera-se, às vezes, que a PÓS compete e, de certa forma, prejudica a graduação, já que se trata de um curso que exige mais investimento na formação de massa crítica e tem uma relação aluno/docente menos favorável e mais onerosa, carreando energia e recursos financeiros, sobretudo quando a GRA está repleta de problemas a resolver. Eu diria que problemas sempre existem e são, em realidade, o reflexo de nossos sonhos de aprimoramento. Vão sempre existir e sempre nos veremos atrás da busca de suas soluções. Somos seres que problematizam, e essa dinâmica de busca está em nossa natureza. Em realidade, muitas das soluções para uma GRA estão no salto para a PÓS. Melhoria de infraestrutura e apoio das agências de fomento para ações de ensino, pesquisa e produção científica, para citar dois casos, desembocam em soluções das lacunas da GRA. Portanto, projetos de pesquisa da PÓS representam oxigenação para o curso como um todo.

Se o projeto representa a oxigenação financeira, o graduando representa a oxigenação de mão de obra, a continuidade para a pesquisa e o reforço para manter o fluxo contínuo de pesquisadores.

\footnotetext{
${ }^{1}$ Neste texto, a palavra design (em caixa baixa) é usada para designar a atividade do designer enquanto projetista, sendo a palavra Design (em caixa alta) utilizada para referirse à disciplina e ao corpo de conhecimento que compreende a área dentro do ramo das Ciências Sociais Aplicadas.
} 
Pecando, talvez, por certo simplismo, eu diria que a integração entre alunos de GRA e PÓS e destes com docentes que atuam nos dois níveis é a pedra de toque do sucesso de um programa de Design. Pelo menos é uma das variáveis para a qualidade do programa, algo reconhecido pelo MEC e pela CAPES quando contabilizam a integração dos dois níveis na avaliação dos programas.

A integração entre graduação e pós-graduação não apenas é recomendada, mas dela depende o nível das pesquisas, uma vez que pesquisadores principiantes têm a oportunidade de atingir excelência com maior rapidez. Quanto mais cedo o aluno da graduação, com potencial para o trabalho investigativo-científico, tiver contato com grupos mais maduros de pesquisa, maior o rendimento do trabalho e melhor o nível dos resultados obtidos. A troca entre pesquisadores iniciantes e veteranos torna-se, assim, essencial.

O profissional que sai da graduação nesse ambiente de trocas com a PÓS ganha a perspectiva da crítica para além da simples produção. Passa a ser um profissional antenado, que vai querer saber dos desdobramentos de seu trabalho. Não fecha o projeto no protótipo, que acaba, muitas vezes, sendo o ponto final dos TCCs.

Para atingir o estágio consolidado de sua pesquisa, um programa de PÓS necessita de estratégias de desenvolvimento da investigação científica na GRA:

1. Identificando onde estão as excelências a partir do que já se vem fazendo (quais os grupos de pesquisa existentes e quais os projetos isolados);

2. Tomando providências de incentivar a pesquisa na GRA (implica vontade política);

3. Identificando pesquisadores em potencial dentre os alunos da GRA;

4. Criando e promovendo pontos de escoamento, quer tornando público os espaços e veículos de divulgação (revistas, congressos, 
exposições, concursos etc.), quer fomentando a geração de produtos, relatórios de pesquisa ou patentes resultantes da pesquisa ou facilitando a clássica produção científica (artigos, palestras, oficinas, livros etc.);

5. Buscando mecanismos de alargamento de possibilidades de fomento: bolsas de iniciação científica (tais como PIBIC, do CNPq, ou as ICs, das FAPs), bolsas internas, bolsas de fundações privadas, bolsas de projeto integrado, bolsas por cota etc. ou por meio de sistema de disciplina que dá créditos de pesquisa na grade da GRA (Introdução à Pesquisa ou Atividades Complementares);

6. Buscando mecanismos automáticos de manutenção desse processo por meio de funções especiais e equipes voltadas para gerir o sistema (coordenações específicas de pesquisa, desenvolvimento, iniciação científica, entre outras).

As oportunidades de um programa de pós-graduação constituem um catalizador positivo não somente para a GRA, mas para o curso como um todo. Os alunos da GRA de um programa que mantém a PÓS passam a contar com conhecimento e estrutura física potenciais que lhes abrem exponencialmente inserções no mercado, pois têm à disposição pessoal e recursos para uma formação diferenciada, mais individualizada, algo que a grade curricular da GRA não permite per se. Isso significa customização funcional para cada mercado e maiores oportunidades de colocação neste, independentemente de o aluno seguir a PÓS. É óbvio que a PÓS, pela titulação e conhecimentos que faculta, amplia oportunidades de ascensão salarial. Muitos dos mestrandos da PUC-Rio hoje - diferentemente do início de nossa PÓS, quando havia uma visível demanda reprimida de formação para a academia - são egressos da indústria ou do setor de serviços, que procuram o mestrado para fins de ascensão empresarial. 
Finalmente, a busca da consolidação se faz por meio da conscientização da importância da pesquisa para a IES e para o aluno e cria uma cultura de pesquisa, com especial atenção à ética e aspectos de recepção, desuso e sustentabilidade.

\section{PARA ALÉM DA INTEGRAÇÃO}

A excelência de um programa acadêmico como um todo, independentemente do foco isolado na graduação ou na pósgraduação, pressupõe que os egressos do curso sejam incentivados em direção a outras buscas e conquistas. Esse objetivo é atingido por meio de:

1. Fomento da relação do Design com outros campos de pesquisa, conforme já valorizado neste texto. A formação hoje deve ser multifacetada. Sem perder foco na especialização enquanto opção de determinado programa de GRA (formação profissional com ênfases específicas), não se deve deixar de considerar um fato da contemporaneidade: as convergências, em especial nas convergências de tecnologia e de serviços (JENKINS, 2009). No design, por exemplo, é o caso do profissional multimídia, que trabalha dentro de um concerto de tecnologias;

2. Busca pela associação interinstitucional, assim como a cooperação entre pesquisadores nacionais e estrangeiros. Há hoje no Brasil, patrocinados pela CAPES, programas de redes de pesquisa com grande número de países e de IES renomadas na área do design. Lançar mão dessa integração ajuda na obtenção de melhores resultados;

3. Incentivo do aluno a participar de associações científicas e seus encontros periódicos, o que resulta em potencial para redes interuniversitárias e caminho para a formação de grupos 
de pesquisa de excelência internacional. Os esforços dessas associações, que mantêm relações com acadêmicos de outros países e promovem a ponte entre estes e pesquisadores brasileiros, ajudam na mudança do patamar da pesquisa em Design.

\section{O IMPACTO DA CRIAÇÃO DA PÓS-GRADUAÇÃO NO DESIGN DA PUC-RIO}

A história da pós-graduação na PUC-Rio passou por algumas fases e representou vontade política da instituição e o esforço do corpo docente e administração do Departamento de Artes \& Design, aliados ao empenho dos pós-graduandos que passaram pelo programa nesses vinte anos.

$1^{\text {a }}$ fase (1994-1996): apesar de termos a ideia clara do que seria um programa de pós-graduação em face da experiência de formação dos próprios doutores que constituíram o programa e do feedback com a experiências de outros departamentos da universidade, não poderíamos imaginar como seria lidar com um campo que ainda não havia sido experimentado no Brasil; como seria trabalhar com o Design em nível de PÓS diante da percepção que outros tinham da área com base na prática profissional, o único balizador que se tinha até então. Foi este, sobretudo, um período de adaptação ao sistema da pós-graduação definido pela CAPES, algo que era novo para nós.

$2^{\text {a }}$ fase (1997-1999): com os primeiros mestres formados, esse foi o período de integração formal. O ingresso de novos alunos, anualmente, somados aos pós-graduandos que já estavam no programa, constituiu o fluxo de formação pós-graduada e o aglutinamento em torno do orientador, simultaneamente à criação de alguns laboratórios e estabelecimentos de projetos isolados dos docentes do programa (patrocinados ou não). 


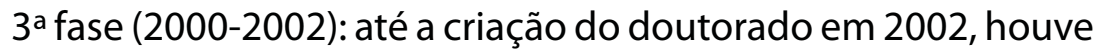
o aumento da massa crítica com a admissão de novos docentes no programa e a inauguração do Instituto de Pesquisa em Design (IPD), com laboratórios de PÓS e seus núcleos, além da organização de projetos que vieram integrar pesquisadores de diferentes laboratórios.

$4^{\text {a }}$ fase (2003-atual): esta vem sendo a fase da integração continuada, com maior organicidade entre alunos de GRA, PÓS e docentes do programa do DAD e de outras unidades da universidade e instituições de naturezas diversas fora da PUC-Rio. Foi o período do oferecimento de Doutorado interinstitucional (DINTER) e de estágios pós-doutorais, com mais intensa cooperação internacional. Também tivemos a criação do Programa de Graduação em Arquitetura e Urbanismo em conjunto com o Departamento de Engenharia Mecânica da PUC - hoje com mestrado stricto sensu reconhecido pela CAPES e constituindo um departamento independente do Design no organograma da universidade.

\section{A PESQUISA COMO BALIZADOR}

A ideia de design está intimamente ligada à de projeto, e a ideia deste, por sua vez, sugere aspectos de pesquisa aplicada compreendida em dado processo de concepção e fabricação. Mas por que mencionar aqui pesquisa associada ao design quando é comum ouvir-se dizer que design refere-se a um fazer, a um projetar, em vez - ou antes - de ser pensado enquanto um ramo particular do conhecimento com seu amplo espectro de indagações envolvendo a investigação científica? Eis, então, que me refiro a essa ideia de projeto como uma película que envolve a prática do design, mas que muitas vezes compreende aquilo que entendemos por pesquisa 
no sentido acadêmico. Não me refiro, obviamente, a um fazer baseado na repetição de um processo de fabricação. Repetir pode justificar um projeto, assim como um projeto pode sintetizar-se em se querer realizar um trabalho qualquer, em querer fazer algo para fins de aprendizagem. Em tais acepções, todavia, projeto não implica pesquisa, quando muito um processo com etapas planejadas. Em contraste, a pesquisa acadêmica representa, além de busca em si, geração de conhecimento por meio de análise cuidadosa de todo o processo: da relação entre variáveis à reflexão sobre causas e consequências da criação e da racionalização da metodologia com consciência dos porquês dos passos adotados até a consecução dos objetivos. Essa noção de pesquisa apaga os limites do que se entende por pesquisa pura e aplicada, restando apenas uma ideia de pesquisa. E é a essa noção de pesquisa a que me refiro. Tratase do tipo de pesquisa que percebo em boa parte dos projetos do Design realizados na academia. E aqui desejo deixar patente que estou convencido de que o Design pressupõe pesquisa científica não apenas nos cursos de pós-graduação, como seria pacífico de se aceitar, mas também em nível de graduação.

Hoje, em meados da segunda década do século XXI - e após vinte anos de história de pós-graduação em Design no Brasil - podese afirmar que não há dúvidas sobre a importância da pesquisa albergada pelo Design no país. Tanto para a comunidade acadêmica dos dezenove programas de PÓS - quinze stricto sensu e quatro lato sensu - comprometidos com a investigação científica diretamente, quanto para as agências governamentais ${ }^{2}$. Mas não foi assim no princípio, na época em que se começou a pensar na necessidade de criação de um mestrado stricto sensu a partir de meados dos anos

\footnotetext{
${ }^{2}$ Apenas a região Norte não possui PÓS em Design, lato ou stricto sensu: são seis na região Nordeste, um na região Centro-Oeste, cinco na região Sudeste e sete na região Sul.
} 
oitenta do século passado. O primeiro programa de pós-graduação stricto sensu em Design começou a funcionar na PUC-Rio em 1994. Naquela época, contudo, a formalização da PÓS pareceu não ter sido suficiente para atestar o foro investigativo-científico a que nos referimos em relação ao Design. A título de ilustração, narro um episódio ocorrido em agosto de 1995, quando dos seminários do PIBIC na instituição. Imediatamente após as apresentações dos bolsistas de Design - e em visível comparação aos trabalhos ali anteriormente apresentados por bolsistas de outras áreas, como Letras e Filosofia a avaliadora do CNPq elogiou nossos projetos do ponto de vista utilitário, mas indagou onde estaria assinalada a pesquisa científica além da práxis. Foi preciso que alguns docentes da área levantassem em defesa do método projetual e seus componentes de investigação pura e aplicada. Foi preciso dizer que adotamos, de fato, métodos científicos na condução de nossos trabalhos acadêmicos. Em realidade, sabemos nós que os projetos oriundos dos bancos das escolas de Design envolvem princípios semelhantes a qualquer projeto acadêmico, inclusive lançando mão de procedimentos tanto da área tecnológica quanto das áreas humana e social. E que talvez introduzam o estudante da graduação no processo de pesquisa mais cedo do que em outras áreas acadêmicas. Apesar disso, a visão do design como atividade profissionalizante impedia que se percebesse tal característica com clareza. O que, acredito, parecia constituir um óbice na obtenção de apoio por parte das agências de fomento. A não ser que - no momento de criação de nosso programa de pósgraduação - optássemos em criar um mestrado profissionalizante. ${ }^{3}$

\footnotetext{
${ }^{3}$ LEALI, Francisco. A lista negra da pós-graduação brasileira, Jornal do Brasil, Seção Brasil, de 29 out. 1995, p. 16, em que se lê que a CAPES previa apoio a programas que demonstrassem interesse nessa direção.
} 
Pouco antes da criação do mestrado em Design da PUC-Rio, surgiu um movimento coeso de um grupo de escolas de Design em torno da demonstração de seus métodos em questões de pesquisa. Criaram-se fóruns científicos para discutir o tema e decidir como sensibilizar os governos federal, estadual e municipal na adoção de políticas públicas. O movimento teve o propósito de dar rumo seguro à condução do ensino e pesquisa do Design. Um exemplo é o grupo de trabalho que organizou o primeiro congresso brasileiro de Design constituído por acadêmicos, com apoio do periódico científico Estudos em Design - cujo segundo número foi lançado nesse congresso - e por componentes da embrionária Associação de Ensino e Pesquisa de Nível Superior de Design do Brasil (AEnDBrasil), formalmente criada anos mais tarde, em 2005. Foi este o I P\&D Design, Congresso Brasileiro de Pesquisa e Desenvolvimento em Design, realizado em São Paulo em 1994, onde aconteceu um encontro com representantes da CEEARTES e onde se discutiu uma pauta de temas que subsidiariam o II e III Fóruns de Avaliação e Reformulação do Ensino Superior de Artes e Design. O II Fórum foi realizado em Campo Grande, MS, em 1994, e identificou a necessidade de critérios homogêneos de avaliação dos cursos de Design do país. Após elaborar um questionário-padrão, optou-se por sua aplicação, a título experimental, em onze IES que se voluntariaram para tal fim. Já o III Fórum aconteceu em Salvador, no mesmo ano.

Ao final do encontro em São Paulo, saiu-se com uma lista de mais de vinte itens, dos quais gostaria de citar cinco: 1) necessidade do estabelecimento de uma teoria e crítica do design; 2) necessidade do estabelecimento de uma teoria do projeto; 3 ) estabelecimento de infraestrutura adequada ao desempenho das atividades de ensino, pesquisa e prestação de serviços à comunidade nas instituições de ensino; 4) necessidade de discussão pormenorizada sobre o papel da 
pesquisa em Design; e 5) promoção do Design. Esses pontos foram retomados em foros específicos de encontros posteriores, como o P\&D (em sua décima quarta edição em 2014).

Cada fase dessa história, dentro e fora do âmbito acadêmico, vem representando cunhas de conquista de espaço com ministérios, agências de fomento, associações patronais e governos regionais, que, por sua vez, também vêm respondendo com ações induzidas para a oxigenação do Design enquanto campo de saber e investigação e enquanto profissão.

Seguiram-se outras associações e encontros, como o Encontro Nacional de Ensino Superior de Design (ENESD) ou o Congresso Internacional de Pesquisa em Design (CIPED), promovendo o incremento da pesquisa e buscando maior visibilidade e melhores condições para o desenvolvimento do ensino do Design no Brasil e no exterior. Hoje temos dezenas de grupos formados por pesquisadores e alunos do Design de diferentes subáreas, que promovem eventos regionais e internacionais. Para citar apenas alguns, temos o Congresso Internacional de Ergonomia e Usabilidade de Interfaces Humano-Tecnologia: Produto, Informações, Ambiente Construído e Transporte (ERGODesign-USIHC) ou o Congresso Internacional de Design de Informação e Congresso de Iniciação Científica em Design de Informação (CIDI-CONGIC), organizado pela Associação Brasileira de Design de Informação (SBDI), que também criou o periódico InfoDesign.

Fora do âmbito do Design, a própria academia percebia a atividade apenas como uma prática, que não carecia de abordagens investigativas de natureza científica, como acontecia com as áreas do chamado núcleo duro das ciências. Era também a época em que se discutiam os MBAs no país. 
A luta em direção ao stricto sensu e à validação do campo como pesquisa científica foi intensa. A decisão institucional era pelo stricto sensu. Havia uma clara e grande demanda reprimida de docentes para os cursos de Design que já existiam e que começavam a surgir na universidade brasileira. Muitos dos docentes que estavam compondo os novos programas de Design vinham de outras áreas da academia. Era preciso abrir espaço para que o Design pudesse adensar seus quadros acadêmicos e criar sua própria massa crítica para programas de pós-graduação emergentes. E assim se fez o PPGDesign da PUC-Rio.

\section{PARA ALÉM DA UNIVERSIDADE}

Seria injusto simplificar o assunto da investigação científica no ensino do Design somente a partir da investidura na criação de programas pós-graduados dos anos oitenta do século XX. A luta iniciase na formalização dos cursos superiores de graduação em Design no país, ocorrida nos anos cinquenta e sessenta do século passado e no processo de reconhecimento e posterior regulamentação da profissão de designer. Luta pelo amadurecimento da área e da atividade ainda em curso sob certos aspectos - liderada por associações e pessoas tenazes, sem as quais não teríamos alcançado as conquistas acadêmicas de hoje. Faz-se mister mencionar, outrossim, outro marco fora do âmbito universitário a partir da segunda metade dos anos setenta. Trata-se das atuações do Centro Nacional de Referência Cultural (CNRC), Fundação Nacional Pró-memória (FNPM), Secretaria de Cultura do MEC e Instituto do Patrimônio Histórico e Artístico Nacional (IPHAN), tendo à frente um designer, Aloísio Magalhães, dando relevo ao valor cultural do produto brasileiro e também contribuindo para a visibilidade da atividade e do profissional. Foi 
esse o embrião do atual movimento em relação a políticas públicas no âmbito do MinC, com repercussão positiva tanto para a academia quanto para a profissão de designer.

$\mathrm{Na}$ estrutura do MinC, existem hoje órgãos setoriais que elaboram planos específicos para submeter ao Conselho Nacional de Políticas Culturais (CNPC) e subsidiar a elaboração do Plano Nacional de Cultura (PNC). Em 2009, o design, moda, arte digital, artesanato, arquitetura e urbanismo foram incorporados ao plano de colegiados setoriais do Ministério da Cultura, e em 2010, deuse a I Pré-conferência Setorial de Design para, em 2012, criar-se o Colegiado Setorial de Design, cuja primeira reunião, em julho de 2013, elaborou o Plano Setorial de Design, depois incorporado à III Conferência Nacional de Cultura (CNC) em novembro de 2013, e definiu políticas públicas do PNC. Além das Conferências Nacionais, com participação de representantes locais e regionais, tem havido, as Conferências Estaduais de Cultura articuladas com as CNCs e com pautas exclusivas para o design (CARDOSO et al., 2014).

No caso do Rio de Janeiro, tem havido as Semanas do Design promovidas pelo setor privado com apoio do governo do estado. Tem havido ações induzidas por parte dos governos estadual e municipal tendo o Design como área estratégica de desenvolvimento regional. Criou-se, por exemplo, o Centro Carioca de Design, iniciativa do governo municipal, o Edital Pró-Design lançado pela Prefeitura do Rio ou Centro Design Rio (CDR), parceria entre os governos estadual e municipal e entidades patronais, MCT, SEBRAE, associações profissionais e instituições de ensino.

É preciso salientar, ainda, o trabalho desenvolvido pelo Laboratório Brasileiro de Desenho Industrial (LBDI). Esse órgão é o resultado da política do Ministério da Indústria, Comércio e Turismo, juntamente com o CNPq e a FINEP, que criaram, em 1984, três 
laboratórios regionais com a missão de cuidar da formação básica em Design para o setor produtivo. A ideia era que esses laboratórios pudessem atuar com empresas para aumentar a competitividade dos produtos e serviços nacionais, visando à substituição de importados e, assim, equilibrando a balança de pagamentos. Os órgãos foram criados no Sul, em Florianópolis; no Sudeste, em São Carlos; e no Nordeste em Campina Grande. Depois de três anos, sem demonstrar os resultados esperados, as entidades de São Paulo e da Paraíba foram extintas e, em 1988, o Laboratório Associado de Desenvolvimento de Produto/Desenho Industrial de Santa Catarina, então dirigido por Gui Bonsiepe, ganha o nome de LBDI, passa e a ser liderado por Eduardo Barroso Neto. Nesse tempo, o LBDI projeta-se nacionalmente, dando cursos e prestando assessoria técnica a empresas. Eventualmente, o CNPq afasta-se do projeto e transfere o LBDI para o SENAI. Em 1995, o governo federal cria o Programa Brasileiro de Design (PBD) aproveitando o know-how do LBDI, e em 1997 o SENAI absorve as ações do laboratório e o extingue (PEREIRA et al., 2010).

\section{O ATUAL PARADIGMA NA PESQUISA}

A grande maioria dos trabalhos de fim de semestre e monografias de pós-graduação - mestrado e doutorado - tem seu foco em temas específicos relativos a ramos clássicos do Design, tais como Comunicação ou Programação Visual, Comunicação Gráfica e Projeto de Produto. Por outro lado, percebe-se o despontar de subáreas de estudo que buscam equacionar aspectos relativos ao Design não ventilados até então. São trabalhos que tratam de enfoques simbólicos ou epistemológicos na recepção, emoção, espiritualidade, subjetividade, retórica etc. 
Que se diga que esse não vem a ser um fenômeno apenas do Design. Essas subáreas representam, na realidade, preocupações globais e também são verificadas em outros campos de conhecimento. Marcam, isto sim, um paradigma contemporâneo da ciência. O amadurecimento da pesquisa é um pré-requisito nesse contexto. É ele quem favorece incursões que acontecem quando já existe uma comunidade formada, que se interessa pelo tema, que o compartilha e que o alimenta no desdobramento da discussão. Vinte anos de pesquisa contínua, por meio dos programas de pós-graduação do Design e seus desdobramentos lógicos - eventos científicos, acordos interinstitucionais e publicações -, sem dúvida respondem pela expansão e qualidade dos trabalhos que vêm se somando nesse tempo.

O novo paradigma também advém do incremento e interesse no estudo das fronteiras semânticas e pragmáticas de determinado campo de conhecimento. Por sua vez, esse interesse promove o alargamento da abordagem desse campo para aspectos intra e extradisciplinares. No caso do Design, especificamente, não bastaria pensar na interface que a área tem em sua própria esfera de ação como, por exemplo, verificar como se dá o relacionamento entre o Design de Produto e o Design Gráfico ou entre estes e ciências ou matérias já incorporadas ao conjunto de disciplinas que figuram nas grades curriculares dos programas de graduação, como Proxemia, Biônica, Ergonomia, Semântica etc. As relações extradisciplinares têm evidenciado espaços potenciais privilegiados de investigação para nossos pesquisadores. Ao se examinar os desdobramentos de subáreas, como as mencionadas acima nos recentes eventos científicos do Design e nos assuntos neles tratados, notam-se tais preocupações e interesses. É natural que com o lastro de massa crítica expandido com que hoje contamos no Brasil, esses desdobramentos ocorram. 
Muito se tem discutido sobre abrangência do Design, a começar pela própria terminologia. Encontros acadêmicos mais recuados no tempo - antes mesmo da criação dos programas de pós-graduação em Design - buscaram palavras que melhor caracterizassem o campo de conhecimento por meio de um termo global que o tipificasse. A questão de se evitar palavras estrangeiras foi bastante discutida nesses foros. Falou-se em Projética, por exemplo. Apesar da intenção, o termo Design tornou-se mais proeminente, e eventualmente trabalhou-se a relação entre Design e Desenho Industrial, ambos termos aceitos, guardadas nuanças de sentido. Mais adiante, discutiuse sobre a abrangência do Design multi e transdisciplinarmente e agora se fala na transversalidade e na complexidade do Design, termos que abrangem a questão da polissemia - o morfema design enquanto substantivo ou verbo ou o termo enquanto carreira ou ofício etc. - que examinam a articulação entre profissão e atividade, e estabelecem relações com outras atividades e profissões, além de com outros campos do saber.

A complexidade no Design pode ser uma vantagem para o campo, sobretudo para a pesquisa, pois que diante do desafio das interfaces de profissões e atividades vizinhas e absorvidas pelo Design vislumbramos uma vasta temática a ser mais trabalhada, espaços potenciais privilegiados, conforme registro acima.

Outra questão sobre complexidade e transversalidade, resultante da natureza líquida do Design, diz respeito ao entendimento por parte das agências de fomento e a classificação do Design nas tabelas de áreas de conhecimento (BAUMAN, 2001). No CNPq, estamos situados em área própria (Desenho Industrial, com duas subáreas: Programação Visual e Desenho de Produto) dentro do grupo da Engenharia de Produção (com Metodologia de Projeto e do Produto, Gerência do Projeto e do Produto, Desenvolvimento 
de Produto), na grande área das Engenharias e no COENG para o Comitê de Assessoramento e Avaliação. Na CAPES, por outro lado, estamos localizados dentro das Ciências Sociais Aplicadas, com área independente (Desenho Industrial) e com a Arquitetura e Urbanismo para fins de avaliação.

Poder-se-ia alegar aqui que nos expandimos para outros campos de reflexão, que extrapolamos nossas fronteiras de ação, que "invadimos" searas alheias. A razão do "protesto" estaria no argumento de que tais campos constituíam domínios de saber e práticas de outras áreas acadêmicas. Entretanto, a expansão do Design deu-se por força de novas percepções e pelo surgimento de oportunidades a partir do adensamento da pesquisa, conforme apontado. Outros campos do saber e profissões, inclusive os mais tradicionais, também expandiram suas fronteiras, o que relativiza a afirmação de que o Design é mais interdisciplinar que outras áreas de conhecimento e ação. Assim, outras áreas, em diferentes graus de interdisciplinaridade, também "invadem" novos campos de interesse, o que parece contribuir para se deixar de lado a ideia de que Design caberia em todo lugar e, portanto, nenhum lugar e que não teria sua especificidade. Concluímos, então, que hoje o paradigma científico é outro e a questão das fronteiras parece tornar-se secundária ou sem sentido no atual cenário.

Vizinho das Artes, das Engenharias, da Comunicação Social, da Arquitetura, do Artesanato, por exemplo, o Design, desenvolveu sua própria práxis e elaborou seu corpo teórico a partir de reflexões anteriores. Passou a gerar conceitos próprios e práticas que o peculiarizam. Mas não em função de limites e fronteiras, mas em função do olhar e da sensibilidade que o designer desenvolve a partir de sua educação formal e dessas práticas. O que acontece com qualquer esfera de atividade humana. Sendo mais específico, 
eu diria que a peculiaridade do olhar do designer está, por exemplo, na preocupação com a identidade ou na combinação desta com aspectos como leiturabilidade e legibilidade, apenas duas marcas evidentes desse olhar.

Em relação à semântica dos termos que gravitam em torno do Design, o Programa de Design da PUC-Rio fez uma opção quando manteve a palavra Artes no título de seu departamento (Artes \& Design). Há algum tempo a unidade era chamada de Departamento de Artes e abrigava as habilitações de Comunicação Visual, Projeto de Produto e Licenciatura em Artes (Arte-educação). Eventualmente deixou de oferecer a licenciatura e criou as habilitações de Mídia Digital e Moda. Pouco antes dessa decisão, passou a adotar a palavra Design em seu título e não abriu mão do binômio Artes e Design. Outros programas, por meio do nome da unidade ou das áreas e subáreas de concentração, as Engenharias ou a Arquitetura e Urbanismo optaram por distintas denominações.

\section{NOVOS RUMOS...}

Ao se pensar nos novos caminhos do Design, ter-se-á de considerar não apenas o campo de atividade e o conhecimento que o envolve, isoladamente, mas a contemporaneidade com suas transformações. Diante dos olhos de uma realidade plasmada surgem denominações que nos indicam rumos diferentes para os profissionais e para a pesquisa; preparam-nos para interstícios do saber e zonas de ação até então inexistentes. Vislumbramos novos atores de uma realidade desconhecida para nós. Hoje o designer já está projetando para a Biotecnologia, criando artefatos que suprirão necessidades alimentares. O mercado fusionado vem ganhando seu contorno há algum tempo. Nesses vinte anos que nos separam do surgimento 
da pós-graduação no Design no Brasil, surgiram vários nichos de atividade projetual e de reflexão teórica. Sem entrar em detalhes do que são ou como surgiram para não agigantar este trabalho, citamos apenas alguns termos que se tornaram proeminentes no período: design de gestão, design estratégico, design de comunicação, design de informação, design de interação, design de interfaces, design de serviços, design universal, ecodesign, less is more, design centrado no usuário, design thinking, branding, open innovation, ideação no projeto, entre outros.

Considerando as mudanças contemporâneas, Daniel Bell fala no pós-industrialismo para caracterizar as transformações de ordem econômica, social e política vividas pelo século XX, chanceladas pelo desenvolvimento tecnológico. $O$ impacto deu-se nas relações sociais, nas relações de trabalho e na maneira como o cidadão passou a interagir com as instituições, inclusive o Estado (BELL, 2008).

Além de Bell, outros autores como Lyotard (1979), Giddens (1990) e Bauman (2000) falam na instabilidade que afetou a sensibilidade contemporânea após um período de certezas patrocinado pela Modernidade. Para Hall (2006), o século XX fragmentou noções de raça, etnia, sexualidade, nacionalidade e classe - e a própria noção da subjetividade - tidas como devidamente mapeadas e certificadas no período moderno (HALL, 2006). Para Sudjic, os novos modos de produção industrial e a publicidade inauguraram o darwinianismo no consumo: artefatos que existiam e eram largamente utilizados foram transformados radicalmente ou extintos, dentro de um sistema de substituição baseado na crença de que o novo é melhor e mais evoluído do que o antigo (SUDJIC, 2009). A substituição é tão célere que frustra a possibilidade identificação entre dono e objeto do período anterior, conforme aponta-se em outro texto (COELHO, 2002). 
Enquanto Bell (2008) acentua a noção de pós-industrialismo a partir da segunda metade do século $X X$, facultado pelo desenvolvimento da tecnologia da informação e comunicação, Giddens (1990) fala na globalização do mesmo período como o motor dessas transformações. A globalização vai responder pelo novo padrão de consumo e de relações sociais, que abole distâncias e antigas noções de tempo. O local e o global fundem-se e a relação de causa e efeito cede espaço para a reciprocidade de impactos. Embora a noção de centro e periferia permaneça, ditada pelo poder econômico, culturalmente a hegemonia desses centros de poder é abalada pelas novas possibilidades de troca. Nesta atmosfera cambiante, profissionais e pesquisadores precisam adequar-se e buscar caminhos.

É difícil antecipar os paradigmas que se avizinham. Temos certeza, entretanto, de que eles virão e que a tecnologia torna-se a molamestra nessa transformação. No atual ambiente profissional, em que já se vive a situação das multicarreiras, a tendência é a de que o movimento se amplie no futuro. $O$ designer de amanhã talvez venha a combinar sua formação projetual a outra que melhor represente seus anseios e perfil expandidos. Em meios às céleres mudanças que se avizinham, é de se imaginar que novos paradigmas surgirão - e mais rapidamente do que em momentos históricos anteriores. Com certeza, as pesquisas do Design continuarão a impulsionar mudanças no panorama acadêmico contribuindo para novas conquistas científicas. 


\section{REFERÊNCIAS}

BAUMAN, Z. Modernidade líquida. Rio de Janeiro: Zahar, 2001.

BELL, D. The Coming of Post-industrial Society. New York: Basic Books, 2008.

CARDOSO, E.; CURTIS, M.; SILVA, T.; ROLDO, L.; LINDEN, J. O papel do design(er) nas políticas públicas culturais.

COELHO, L. A. Tal objeto, tal dono. In: LOPES, L. P. M.; BASTOS, L. (Org.). Identidades, recortes multi e interdisciplinares. Campinas: Mercado das Letras, 2002, v. 1, p. 69-81.

ENSAIO. AVALIAÇÃO E POLÍTICAS PÚBLICAS EM EDUCAÇÃO. Rio de Janeiro: Fundação CESGRANRIO, v. 3, n. 6, jan./mar. 1995. Ensaios.

GIDDENS, A. The Consequences of Modernity. Stanford, CA: Stanford University Press, 1990.

HALL, S. A Identidade Cultural na Pós-Modernidade. 11.Ed. Tradução: Tomaz Tadeu da Silva; Guacira Lopes Louro. Rio de Janeiro: DP\&A Editora, 2006.

JENKINS, Henry. Cultura da convergência. 2. ed. São Paulo: Aleph, 2009.

LEALI, F A lista negra da pós-graduação brasileira. Jornal do Brasil, Rio de Janeiro, 29 out. 1995, Seção Brasil, p. 16.

LYOTARD, J. La condition postmoderne: rapport sur le savoir. Paris: Les Éditions de Minuit, 1979 (Collection Critique).

Ministério da Educação e do Desporto, Secretaria de Educação Superior, Comissão de especialistas de ensino de Artes e Design. Projeto de Avaliação dos cursos superiores de Artes e Design Relatório de 1994. Brasília, dezembro de 1994. 
PEREIRA, L. M; MEDEIROS, Maria Carolina; SILVA, José Carlos Plácido da. Laboratório Brasileiro de Design: uma revisão da sua importância histórica para o Design brasileiro. In: P\&D DESIGN, 9, 2010, São Paulo, ANAIS.

SUDJIC, D. The Language of Things: Design, Luxury, Fashion, Art: how we are seduced by the objects around us. London: Penguin Books, 2009. 


\section{Criatividade e inovação}

Ligia Maria Sampaio de Medeiros (Currículo Lattes)

\section{INTRODUÇÃO}

O presente capítulo registra parte do conteúdo da palestra "Criatividade e inovação" ministrada na primeira edição do Simpósio de Pesquisa Técnico-Científica do Mestrado em Design da Univille. Após a palestra, já no momento dedicado a perguntas e comentários, estudantes da plateia manifestaram dúvidas muito semelhantes às que escuto dos meus próprios alunos hoje em dia e há muitos anos. $\mathrm{O}$ assunto criatividade e inovação, assim eu confirmo, ainda suscita atitudes contraditórias entre estudantes. Se por um lado eles não vacilam ao responderem que conhecem essas palavras, e 
que estão familiarizados com elas, por outro expressam hesitação quando indagados, por exemplo, "como reconhecem o resultado da criatividade?".

As conversas sobre esse assunto, portanto, nunca são monótonas, mas podem ser infrutíferas se não se estabelecem alguns pontos de referência. Foi o que me dispus a fazer no Simpósio, e registrarei na primeira parte deste capítulo. Na segunda parte, apresentarei um material elaborado com um dos meus estudantes de pós-graduação entre 2007 e 2008, ainda não devidamente divulgado. As figuras, que foram originalmente desenhadas por André Nasi (2008) para compor monografia em curso de especialização, são muitas vezes utilizadas por mim pela sua atualidade e relevância. Aproveitei a oportunidade da escrita deste texto para ampliar o alcance daquela contribuição.

As etapas do processo criativo foram interpretadas por Nasi a partir das denominações estabelecidas por Gomes (2004). Os "Cartões" (aqui redesenhados e ilustrados nas Figuras 1 a 7) apresentam linguagem acessível e empática àqueles que lidam com atividades projetuais. Podem perfeitamente acompanhar a estruturação de trabalhos acadêmicos, o projeto de produtos ou o planejamento de campanhas publicitárias. A intenção de Nasi (que orientava estagiários na Agência Experimental de Publicidade e Propaganda da FAMECOS/PUCRS) era sugerir um roteiro com as etapas do processo criativo e sua descrição, para que os estudantes identificassem em que ponto se encontravam no caminho até a conclusão do projeto.

Ao observarmos a rotina de trabalho em escritórios de design e agências de publicidade, muitas vezes constatamos que tarefas são concluídas sem que os problemas tenham sido plenamente compreendidos. Identificamos também que o desconhecimento sobre o próprio processo criativo gera em estudantes, e até em profissionais experientes, desgaste emocional prejudicial à qualidade 
do trabalho e à confiança do indivíduo nas suas próprias capacidades e competências. Para esses casos, lembretes coloridos do percurso do processo criativo associado ao processo projetual, na forma de cartões, poderia ser proveitoso. O diagrama da Figura 8 se apresenta como uma explicação também humorada dos riscos de se pular etapas no processo criativo. A metáfora do diagnóstico a partir dos sintomas causados por essa omissão deu origem ao "Dr. Pulo".

\section{A CRIATIVIDADE É UM FENÔMENO HUMANO. A INOVAÇÃO, UM FENÔMENO SOCIAL}

Criatividade é uma potência humana que permite que nos ajustemos às demandas da vida, sejam elas automotivadas, ou sejam impostas por circunstâncias. Inovação depende da criatividade de indivíduos que, por sua vez, compõem uma vasta rede técnica, econômica e política, portanto é social. A inovação exige criatividade tanto no nível projetual quanto gerencial de quem propõe, de quem financia e de quem consome. Uma empresa inovadora valoriza a criatividade como um agente catalisador: aquilo que acelera uma reação, diminuindo a energia de ativação, sem se consumir durante o processo.

Empresas são feitas de pessoas, portanto criatividade e inovação devem ser estudadas em conjunto. $O$ interesse sobre a criatividade não é recente, mas alcançou fortemente o mundo dos negócios, seja pelo interesse na análise da inventividade depositada em produtos e processos, seja na gestão e nos serviços. Atualmente, a discussão se volta para a singularidade da criatividade humana, num contexto que inclui a inteligência artificial e a possibilidade de máquinas executarem tarefas. Se, no passado, a criatividade já esteve associada à loucura, hoje ela é considerada atributo desejável do 
trabalhador, pois representa a capacidade do indivíduo de solucionar problemas. Mas será que os recrutadores nos departamentos de recursos humanos sabem mesmo o que é um "profissional criativo"? O que se espera num concurso que vai premiar "a frase mais criativa"? E quando nos dizem "ese sua criatividade!" o que pretendem?

\section{COMO RECONHECER A CRIATIVIDADE?}

A partir do conceito de pensamento divergente desenvolvido por Guilford (1967), Torrance (1974) elaborou testes para reconhecer o pensamento criativo. Até hoje esses testes podem ser utilizados como referência quando se trata de identificar respostas e atitudes criativas. Guilford distinguia o pensamento divergente do convergente da seguinte maneira: enquanto o último é focado em uma única e correta ou convencional solução, o primeiro se expande em várias direções. Essa amplitude de respostas é potencialmente benéfica para a construção de soluções criativas. Guilford desenvolveu um grande número de testes visando identificar e classificar os diferentes tipos de pensamento. Os mais conhecidos são:

1. Atribuição de título: o maior número de títulos a uma pequena história;

2. Antecipação de consequências: efeitos para eventos hipotéticos;

3. Utilização alternativa: múltiplos usos para um objeto corriqueiro. As pesquisas de Torrance indicavam que, sendo um processo mental, a criatividade reúne um grupo de capacidades relacionadas. É na presença delas, em conjunto, que se reconhece a criatividade. Segundo Torrance (1974) essas capacidades são:

1. Fluência, que se revela pelo grande número de ideias e soluções propostas, em determinado tempo, a partir de um estímulo. Por exemplo, listar o que é vermelho ou fica vermelho; 
2. Flexibilidade, número de diferentes classes de respostas relevantes. A diversidade nas categorias de respostas se desenvolve por contraste, oposição, contiguidade, sucessão, emulação, afinidade ou semelhança;

3. Originalidade, raridade das soluções, isto é, sua baixa probabilidade de ocorrência, ou diferença estatística. São ressaltadas as respostas inesperadas, que vão além do óbvio, imediato e trivial;

4. Elaboração, grau de detalhamento das respostas, o investimento realizado no aprofundamento e na expansão de conceitos, das relações entre partes e conjuntos, entre causa e efeito, entre tempo e lugar.

Quem insiste, seja no teste, seja em qualquer outra atividade, até completar o maior número possível de respostas, quem tenta associar classes diferentes de respostas, quem corre o risco do salto imaginativo e quem persevera na elaboração demonstra características louváveis. Mas isso não é suficiente para se reconhecer o produto da criatividade. Além de aptidão, motivação, conhecimento, a criatividade é condicionada ao reconhecimento de outros: da família, dos professores, dos chefes, dos clientes, do próprio momento sócio-histórico, que filtram o que não é assimilável naquele contexto.

Aqui então se compreende por que criatividade e inovação se entrelaçam. Inovação é um produto novo ou melhorado que alcançou o estágio de comercialização. Pode ser também um processo ou sistema que alcançou o estágio de implementação. A inovação se cumpre a partir dos princípios da relevância e da contextualidade, pois não basta ser tecnologicamente viável, ela deve ser efetivamente comercializada e difundida e, para isso, precisa ser compreendida pelos usuários como suficientemente relevante para ser adotada, 
assimilada, aceita e considerada como preferível quando comparada com o que existia anteriormente num determinado contexto geográfico e temporal. A inovação, portanto, requer criatividade tanto no nível projetual quanto gerencial de quem propõe e desenvolve, de quem apoia e financia e de quem compra e consome.

Bruce Archer (1974) lembrou que toda criatividade - apesar de admirável em si mesma - demanda um considerável grau de imaginação e receptividade por parte daqueles que lhe darão suporte técnico, empresarial e de consumo.

\section{ETAPAS DO PROCESSO CRIATIVO, CARTÕES E DR. PULO}

Gomes (2004-2011), que tem se dedicado ao estudo da criatividade aplicada à educação projetual e ao ensino de desenho industrial/design, explica como o processo criativo percorre as etapas de Identificação, Preparação, Incubação, Esquentação, Iluminação, Elaboração e Verificação. Com base na descrição dessas etapas, na sua associação com fases metodológicas do processo projetual e os estágios da expressão gráfica, os cartões das Figuras 1 a 7 foram elaborados. O objetivo inicial foi conjugar a experiência profissional de André Nasi na Agência Experimental da Faculdade de Comunicação Social da PUCRS com a realização da monografia de conclusão de curso de especialização, na mesma universidade.

Os cartões contém uma explicação objetiva das características de cada etapa do processo criativo, divididas em ações esperadas, objetivos, desvios comuns e indesejados e condições posteriores. Originalmente, estavam escalonados em linhas denominadas "Antes", "Faça", "Procure", "Evite" e "Depois". As figuras que se seguem resultam de atualização dos termos que agora são: "Antes", "Ação", "Reflexão", "Atenção" e "Depois". A Figura 8 mostra o "Dr. Pulo", complementar 
aos "Cartões". Destina-se a identificar causas da desorganização no processo criativo e ajudar o estudante ou profissional a analisar seu próprio processo criativo e diagnosticar possíveis causas de seus bloqueios. As dicas podem ser úteis para divertir o leitor e, quem sabe, minimizar a angústia que por vezes aflige o profissional criativo. 
Figura 1 - Cartão de identificação

\section{Identificação}

气 Bom, se existisse Etapa Zero, seria algo como: leia muito, pratique exercícios físicos, cuide da alimentação, durma bem, beba água... Dicas que valem sempre.

Leia o enunciado do projeto (também chamado

- de briefing, PIT, JOB, Ordem de Serviço). Ele deve

«্ produto ou serviço, o público, o prazo. Não existe solução sem problema. Leia o problema.

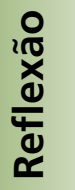

Responda as perguntas o que, quando, onde, por que, para quem com base no enunciado. Se as respostas não estiverem ali, procure completálas com o professor ou o cliente que solicitou o trabalho (algo como: "volte 1 casa").

Evite simplificar o problema. É possível que isso

芯 torne o trabalho mais rápido, mas é provável também que a solução fique óbvia, banal. Se o problema é grande, merece uma grande solução. E se for um problema pequeno, melhor!

$\frac{n}{\circ}$

Você deve ter feito várias perguntas, respondido a todas e compreendido de verdade as respostas. Para prosseguir com segurança você ser capaz de formular a definição do problema. 
Figura 2 - Cartão de preparação

\section{Preparação}

Tenha em mente a definição do problema.

Descubra o que já foi feito sobre o produto ou serviço,

ঙ্ত্রে como funciona, como as pessoas querem que ele funcione. Pesquise os concorrentes, os pontos de venda, como se comportam os usuários. Entenda o contexto.

을 Analise as informações que reunir. Anote o que for percebendo e verbalize pensamentos (vale falar sozinho...). Não deixe as ideias soltas. Falar e escrever são maneiras de organizar os conceitos, e você voltará a eles mais tarde.

Evite fazer uma pesquisa infinita. Com o problema

'્্ّ definido, você sabe o que está procurando. Durante a d pesquisa, aparecem coisas interessantíssimas, mas que não têm relação com o problema. Deixe para outra hora.

$\frac{n}{8}$

Para prosseguir, você deve ter condições de discursar por alguns minutos sobre o problema e o seu contexto. 
Figura 3 - Cartão de incubação

\section{Incubação}

ఋ Tenha anotado em lugar fácil de encontrar o que reuniu e descobriu durante a Preparação.

Mude de ambiente, nem que seja por quinze

- minutos. Levante da cadeira, se espreguice,

荧 fale sobre outros assuntos, tire o trabalho da cabeça (ou a cabeça do trabalho). Tome banho, saia com o cachorro, vá ao cinema.

i̊ి Dê à mente algum tempo para a acomodação das ideias. Guarde seu material e relaxe. Muita coisa na cabeça faz qualquer um pirar e travar. Boas ideias precisam de ar, água, café, chocolate, chimarrão, música...

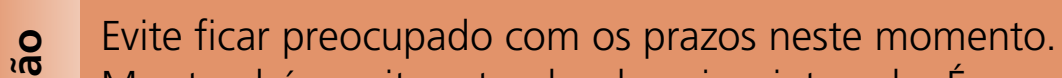

空 Mas também evite estender demais o intervalo. É para

๕ relaxar, não para fugir. O objetivo é ganhar ânimo

$\varangle$ e rapidez para as próximas etapas do trabalho.

$\frac{n}{\circ}$

Você estará mais preparado para trabalhar na solução criativa. 
Figura 4 - Cartão de Esquentação

\section{Esquentação}

气 Pegue lápis e papel. Respire fundo.

¿ Oxigene os pulmões e o cérebro.

Comece lembrando e escrevendo o que já sabe sobre

i⿱乛龰 O problema e rabisque, decalque, recorte, cole, dobre.

\& importante é registrar as ideias que estão na sua cabeça. Elas já estão lá. Puxe o fio da meada.

20 Permita-se experimentar, arriscar novas e estranhas conexões. O objetivo desta etapa é romper a inércia, aquecer a máquina, alongar os músculos, melhorar a flexibilidade mental e a agilidade manual.

$\therefore$ Evite excluir ideias. Mesmo o que não parece bom no

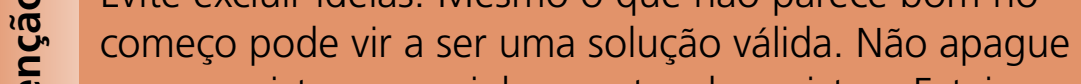

Ф o que registrou nem julgue antes de registrar. Esteja preparado para gastar muito lápis e papel. Faz parte.

$\because$ Você trabalhou com várias possibilidades

de solução, uma delas deve ser mais

promissora do que as outras, mas qual? 
Figura 5 - Cartão de iluminação

\section{Iluminação}

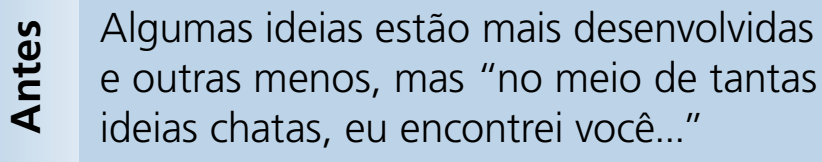

Atenda o chamado daquela ideia que puxa o seu

- olhar, que não sai da sua cabeça, que sussurra

ণ্তু no seu ouvido. Ela pode ser revolucionária, algo ninguém imaginou, ou a que é mais bonita. Siga em frente com aquela na qual mais acredita.

iீ Procure converter intuição em razão e ser honesto em seus argumentos para a escolha do caminho de solução. Apressar-se neste momento pode fazer com que você tenha que "voltar várias casas".

Evite ficar esperando por uma iluminação única

20. e fulgurante, com sinos tocando, estrelinhas piscando, lâmpadas acendendo. Ao longo de um projeto existem pequenas e grandes iluminações. Algumas são bem discretas.

․ㅡㅇ A iluminação discreta vem acompanhada de um

: sorriso, de uma melhora no humor. A iluminação

ospetacular vem com um "eureka!". Comemore! 
Figura 6 - Cartão de elaboração

\section{Elaboração}

气 Com a sua ideia na cabeça e no papel, prepare-

se para botar a mão na massa. Se fosse o poeta

\& Olavo Bilac, chamaria isso de Profissão de fé.

Defina tamanhos, cores, formas, fontes, escolha o

20․ papel, escreva e reescreva textos, títulos, legendas, estude as dobras, as facas, encontre as fotos, tire as fotos, faça as ilustrações, diagrame tudo.

i) Procure deixar o trabalho o mais próximo do que pode mudar e, se for para melhor, você está no caminho certo. Capricho, cuidado, persistência e tenacidade são as palavras de ordem.

Evite voltar às ideias anteriores para compará-

胥 las. Se quiser fazer isso, volte MESMO. Não fique lamentando ter deixado alguma ideia para trás. Se isso estiver acontecendo, talvez valha a pena parar tudo e reconsiderar.

$\frac{n}{\circ}$

Você deve estar com o trabalho pronto ou faltando pouco para terminar. Então só falta a... 
Figura 7 - Cartão de verificação

\section{Verificação}

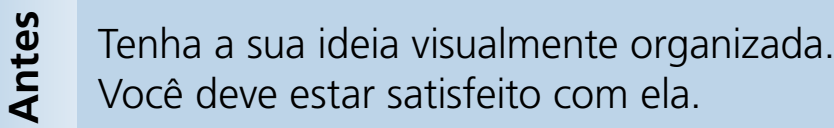

Volte ao enunciado do projeto. Sim, ele guiou você

을 durante todo o processo, mas se algo escapou, é melhor ouvir reclamação do briefing, PIT, JOB, Ordem de Serviço do que do cliente ou do professor.

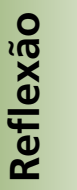

Além de rever periodicamente o enunciado, procure manter comunicação com o cliente ou professor, para verificações parciais. A Verificação é a "última etapa" apenas para fins de descrição do processo criativo.

Evite tomar as críticas como ataques pessoais. Você tem

¿్ָ consciência de que realizou o trabalho com máxima

Фे qualidade, mas pode ter falhado em algum aspecto.

$\varangle$ Se tiver sido este o caso, disponha-se a melhorar já.

\section{$\frac{n}{\circ}$}

Ideia boa, bem executada, passou por todos os testes! Trabalho concluído, volte à Etapa Zero: leia muito, pratique exercícios, cuide da alimentação, durma bem, beba água ... Dicas que valem sempre. 
Figura 8 - Dr. Pulo e o diagnóstico do criativo (parte 1)

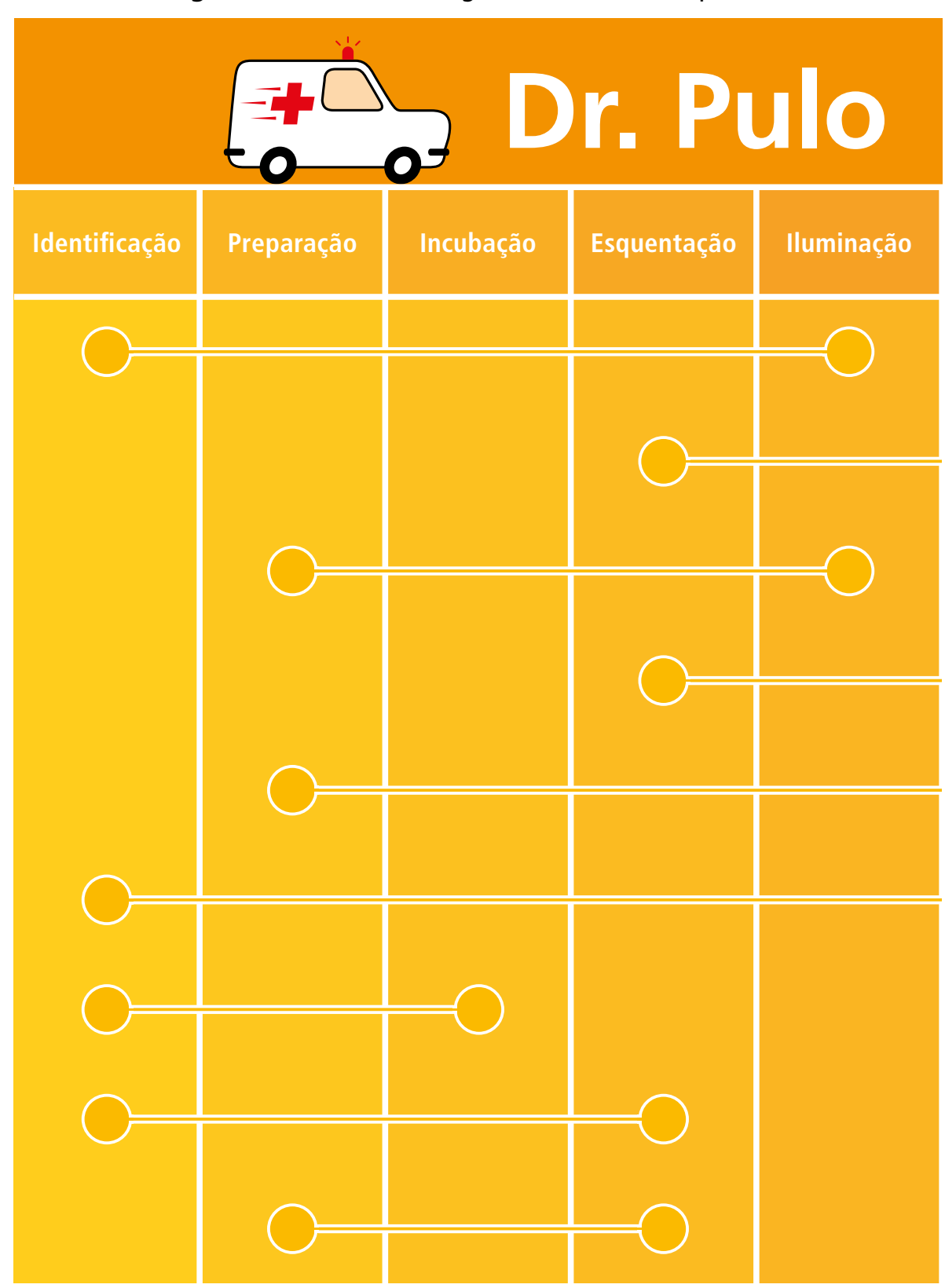


Figura 8 - Dr. Pulo e o diagnóstico do criativo (parte 2)

\section{O diagnóstico do criativo}

\begin{tabular}{|l|l} 
Elaboração & Verificação \\
\hline & Sintomas \\
incriveis! E só. E ainda fica dando palpite. \\
O paciente tem a dúvida permanente \\
se está no caminho certo e \\
trabalha com a melhor ideia. \\
As soluções são óbvias. O processo de \\
criação se baseia em alguma informação \\
encontrada na Preparação. \\
As ideias são avaliadas antes mesmo \\
de se tornarem alguma coisa. Bloqueio \\
criativo por medo do julgamento. \\
O paciente vê algo que serve; se \\
gostou, faz. Quase uma cópia. Não \\
tem como ficar diferente. \\
Macarrão instantâneo - o popular \\
miojo. É o próprio briefing, em \\
outro formato (e mais caro). \\
Estático. É como tentar entrar em casa \\
sem saber onde fica a porta. Síndrome \\
da folha em branco. Tábua rasa. \\
Muitos riscos aleatórios e nenhum sabe \\
de que não vai dar tempo. \\
\hline \hline
\end{tabular}




\section{REFERÊNCIAS}

ARCHER, B. Design awareness and planned creativity in industry. London: The Design Council, 1974.

GOMES, L. V. N. Criatividade \& Design. Porto Alegre: sCHDs, 2011.

Criatividade: projeto $<$ desenho $>$ produto. Santa Maria: sCHDs, 2004.

GUILFORD, J.P. The Nature of Human Intelligence. Nova lorque: McGraw-Hill, 1967.

NASI, A. Aplicação da metodologia do processo criativo na Agência Experimental de Publicidade e Propaganda da Famecos. 2008. 56 f. Trabalho de conclusão de curso (Especialização em Expressão Gráfica) - PUCRS, Porto Alegre, 2008.

TORRANCE, E.P. Torrance Tests of Creative Thinking. Benseville, IL. Scholastic Testing Service, Inc, 1974. 



\section{Design de produto médico-hospitalar: projeto e desenho | coletor de urina sistema fechado para perna}

Andréia Bordini de Brito (Currículo Lattes)

Uda Souza Fialho (Currículo Lattes)

José Fialho de Oliveira Júnior (Currículo Lattes)

\section{A ÁREA DE PRODUTOS MÉDICO-HOSPITALARES NO BRASIL: COLETOR DE URINA SISTEMA FECHADO PARA PERNA}

A água que circula no organismo é resultado da ingestão de líquidos e alimentos sólidos e dos processos metabólicos de oxidação. Ainda que o excesso de água seja eliminado pela pele, pulmões e sistema gastrointestinal, o sistema urinário é o principal responsável pela eliminação da água do organismo. O processo de eliminação da urina envolve reflexos inconscientes e comandos voluntários. Quando a bexiga enche, os receptores da sua parede mandam a mensagem ao cérebro de que a urina precisa ser eliminada, provocando o desejo 
de urinar. Para que esse processo ocorra de maneira efetiva são necessários vários elementos, como os nervos que levam a mensagem dos receptores da parede da bexiga até o cérebro, a função cerebral para inibir o reflexo, os nervos que irão enviar a mensagem de inibição e os músculos envolvidos no processo de reter e eliminar a urina, como os do assoalho pélvico e o esfíncter uretral.

A falha de algum desses elementos pode comprometer 0 funcionamento do sistema urinário de forma transitória e facilmente tratável ou de forma duradoura ou permanente, afetando indivíduos de qualquer idade ou nível sócioeconômico. Para solucionar os diversos problemas no trato urinário, pode-se citar, de forma geral, medidas não invasivas, empregadas na tentativa de estimular a micção, ou medidas invasivas, em que há inserção de uma sonda para esvaziamento da bexiga. A sondagem ou cateterismo vesical é um exemplo de medida invasiva que tem por finalidade a remoção da urina por meio da inserção de uma sonda ${ }^{1}$ ou cateter $^{2}$ na bexiga, através da uretra ou por via suprapúbica.

As causas que levam uma pessoa à necessidade da sondagem vesical são variadas, como situações cirúrgicas (antes, durante e após a cirurgia), incontinência urinária, obstrução da saída da bexiga, entre outras (GOULD, 2009). As sondas podem ser inseridas por um curto período de tempo e removidas logo após o uso (sondas de alívio) ou mantidas no local no período de dias ou mais (sondas de demora), quando há a necessidade de sua permanência.

A sonda de alívio pode ser utilizada para drenar uma bexiga distendida, obter uma amostra de urina estéril, medir a urina residual ou esvaziar a bexiga antes da cirurgia. Enquanto a sonda de demora

\footnotetext{
${ }^{1}$ Tubo que se introduz em canal do organismo, natural ou não para reconhecer-lhe o estado, extrair ou introduzir algum tipo de matéria.

${ }^{2}$ Instrumento tubular que é inserido no corpo para retirar líquidos, introdu-zir sangue, soro, medicamentos e efetuar investigações diagnósticas
} 
é usada para propiciar drenagem vesical contínua ou alternada, introduzir gota a gota uma substância medicamentosa ou líquidos para irrigação, monitorar e contornar a produção de urina dos pacientes (ATKINSON; MURRAY, 1989); assim, as sondas de demora possuem saída dupla: uma saída tem a finalidade de drenar a urina, e a outra serve para inflar o balão próximo à extremidade da sonda, que a mantém presa no interior da bexiga.

Nesse contexto, o tempo de permanência da cateterização vesical é o fator decisivo para o surgimento de infecções (ANVISA, 2013). Conforme apontam Mike e Tambyah (2001), a contaminação por bactérias pode ocorrer durante a inserção do cateter ou posteriormente quando as bactérias ascendem pela superfície externa do cateter (Contaminação Extraluminal) ou quando há refluxo de micro-organismos que estão na bolsa de urina (Contaminação Intraluminal) devido à falha do sistema de drenagem fechada ou pela urina contida na bolsa. Dessa forma, as sondas de demora devem ser utilizadas com um sistema fechado de drenagem urinária, que permite a introdução de uma solução sem a abertura do sistema, reduzindo assim o risco de infecção.

No sistema fechado de drenagem urinária, também conhecido como coletor de urina sistema fechado, a urina que se encontra na bexiga flui através da sonda para a bolsa coletora devido à ação da gravidade (método de drenagem direta). Sua estrutura é composta por uma sonda ou cateter de demora, um tubo de conexão e uma bolsa coletora, que é esvaziada através de uma válvula de saída. Os coletores de urina podem ser classificados em dois grandes grupos:

I) Coletor de urina sistema fechado (Figura 1): possui capacidade para maiores volumes de urina (por volta de $2.000 \mathrm{ml}$ ) e é utilizado em leitos hospitalares e domésticos, geralmente suspenso na cama do paciente. 
II) Coletor de urina sistema fechado para perna (Figura 2): possui capacidade para volumes pequenos (em torno de $500 \mathrm{ml}$ ) e fica localizado por baixo da roupa, fixo à perna do usuário por meio de correias, permitindo seu deslocamento para a realização de atividades ao longo do dia.

Figura 1 - Coletor de urina sistema fechado para leito

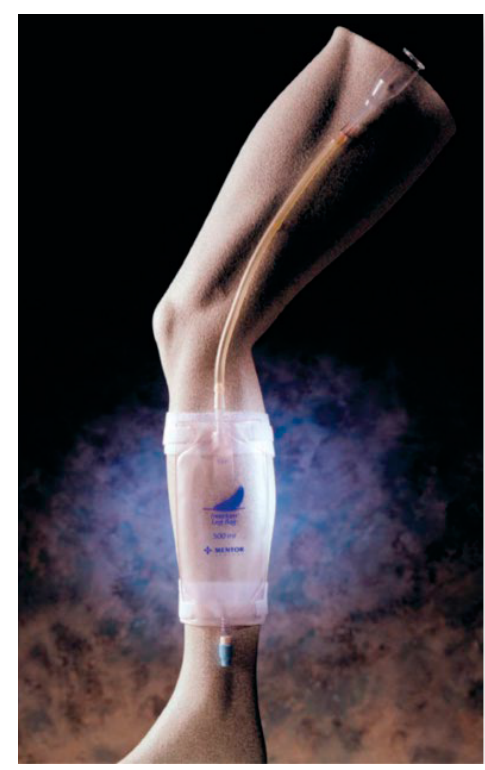

Fonte: www.medscape.com
Figura 2 - Coletor de urina sistema fechado para perna

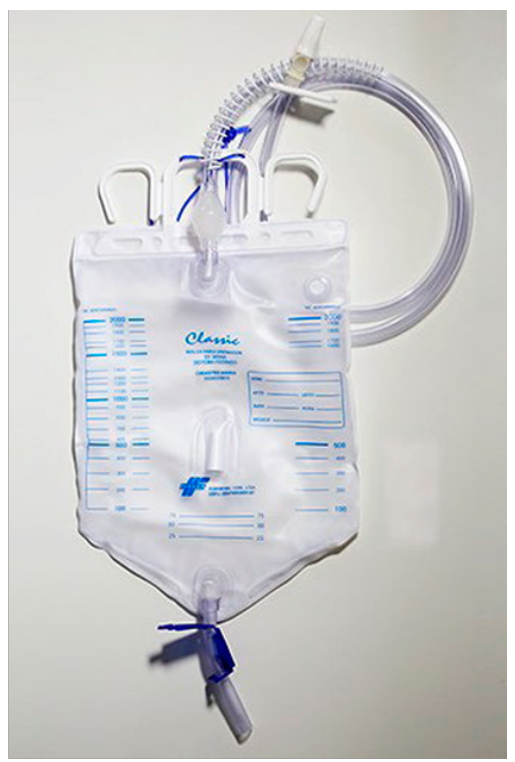

Fonte: www.flexor.ind.br

As pessoas utilizam o coletor de urina para perna, principalmente, devido a problemas de saúde que ocasionaram incontinência urinária. Contudo, essas pessoas buscam conduzir sua rotina da forma mais natural possível, realizando as atividades diárias de forma segura e confortável. De acordo com Cottenden (2009), o desafio para as pessoas que possuem incontinência urinária é descobrir a forma de lidar com esse problema para que os impactos causados na sua qualidade de vida sejam mínimos. Isso envolve a utilização 
de um produto que aja no controle da continência, na contenção de vazamentos de urina ou no gerenciamento da retenção urinária.

A empresa $X$ atua no setor de produtos médico-hospitalares e desenvolve, entre outros produtos, uma linha descartável de coletores de urina sistema fechado para leitos de hospitais, destinada ao público adulto e infantil. A empresa identificou que os coletores de urina para perna existentes no mercado apresentam-se similares e não indicam que há uma busca por melhorias no produto para atender e acompanhar o estilo de vida dos usuários. Assim, a empresa $X$ propôs o desenvolvimento desse produto, buscando atender à demanda do âmbito de mercado em que atua. $O$ objetivo deste estudo foi desenvolver um coletor de urina sistema fechado para perna, disponibilizando ao mercado um produto que atenda melhor às necessidades do usuário em termos funcionais, estéticos e simbólicos.

\section{PROCESSO DE DESENHO PROJETUAL: FASES DO PROJETO PARA DESENHO DE PRODUTO MÉDICO-HOSPITALAR}

O levantamento de dados e as análises foram realizados com a utilização de produtos cedidos pela empresa, de produtos encontrados no mercado e de buscas na internet. As análises, baseadas nos subsistemas do produto, foram realizadas para conhecer a estrutura, as funções, a ergonomia, os atributos semânticos e estéticos, entre outras características dos coletores de urina analisadas em função do público-alvo em questão. As técnicas utilizadas foram documentação/análise fotográfica, desenhos esquemáticos e estruturais e prototipagem rápida. 


\section{Análise denotativa e conotativa}

Conforme Brito (2004, p. 6), "as técnicas de análise denotativa e conotativa dizem respeito ao reconhecimento de termos, expressões e conceitos relacionados com o tema projetual". A análise denotativa (Figura 3) aborda os significados literários, contidos em dicionários, compêndios e afins, que independem do contexto em questão. Enquanto a conotativa (Figura 3) busca os significados que as coisas vão adquirindo ao longo do tempo, realizada por meio de revisão literária; o significado está ligado a um contexto específico. A análise denotativa foi realizada com as palavras coletor e bolsa, que não estão ligadas ao contexto específico, e sim à função de armazenamento. Para a conotativa, considerou-se o termo bolsa de drenagem urinária, inserido no contexto do problema estudado.

Figura 3 - Análise denotativa e conotativa

\begin{tabular}{|c|c|c|c|}
\hline & \multicolumn{3}{|c|}{ Análise denotativa } \\
\hline & Aurélio & Larousse & Michaelis \\
\hline$\stackrel{\mathscr{D}}{\circ}$ & $\begin{array}{l}\text { 1. Cavidade que contém secreção, ou outro } \\
\text { fluido. 2. Bolsa de colostomia. Recipiente } \\
\text { destinado a coletar matéria fecal eliminada } \\
\text { através de colostomia. }\end{array}$ & $\begin{array}{l}\text { 1. Saco de pequena dimensão, } \\
\text { selado, para embalar produtos } \\
\text { líquidos ou pastosos. }\end{array}$ & $\begin{array}{l}\text { 1. Recipiente de pano, couro ou matéria } \\
\text { plástica, cuja boca possui, às vezes, um } \\
\text { sistema qualquer de fechamento, como } \\
\text { ziper, botöes etc. }\end{array}$ \\
\hline \multirow[t]{2}{*}{$\frac{\bar{g}}{\mathrm{o}}$} & $\begin{array}{l}\text { 1. Que colige, compila, reúne. } 2 \text {. Diz-se de } \\
\text { cano principal de esgoto, ou de águas pluviais, } \\
\text { no qual se entroncam os canais secundários. }\end{array}$ & $\begin{array}{l}\text { 1. Todo recipiente em que se } \\
\text { juntam coisas. }\end{array}$ & $\begin{array}{l}\text { 1. Aparelho ou recipiente destinado a } \\
\text { recolher alguma substância. }\end{array}$ \\
\hline & \multicolumn{3}{|c|}{ Análise conotativa } \\
\hline$\frac{\sqrt[\pi]{\frac{\pi}{2}}}{2}$ & Weber et al. (2004) & Não identificado & Williams \&Wilkins \\
\hline 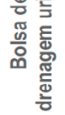 & $\begin{array}{l}\text { 1. Dispositivo pequeno que se adere à perna } \\
\text { mediante bandas elásticas. }\end{array}$ & $\begin{array}{l}\text { 1. Dispositivo utilizado para cortar } \\
\text { fluidos, é utilizada presa na perna. }\end{array}$ & $\begin{array}{l}\text { A bolsa de perna armazena menos urina } \\
\text { que a bolsa de drenagem (a que se usa } \\
\text { deitado), mas permite que a pessoa se } \\
\text { movimente com maior facilidade. }\end{array}$ \\
\hline
\end{tabular}

Fonte: elaborada pelos autores

\section{Análise diacrônica}

A análise diacrônica consiste na investigação da origem e evolução do produto em questão. Para a realização dessa análise foram tomados como referência os produtos desenvolvidos para 
incontinência urinária que possuem registros históricos, assim como mostra a Figura 4.

Figura 4 - Análise diacrônica

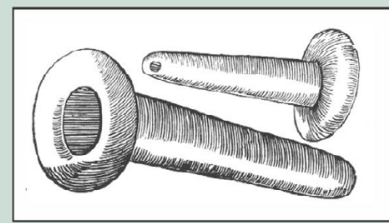

Artificial Yard, 1564

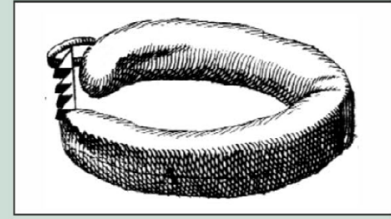

Pinça peniana, 1747

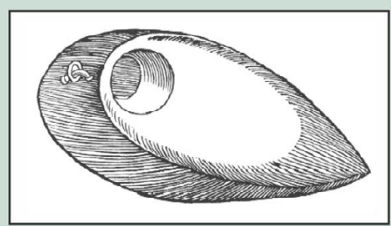

Urinol masculino, 1564

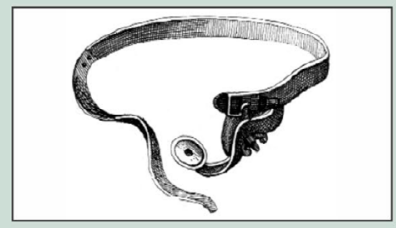

Cinto de compressão, 1747

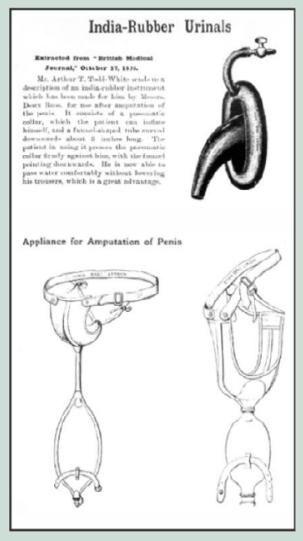

Catálogo, 1906

Fonte: elaborado pelos autores, baseada em Schultheiss (2009)

\section{Análise sincrônica}

O objetivo da análise sincrônica é conhecer e compreender o mercado onde o produto será inserido, possibilitando a descoberta de problemas em produtos concorrentes, que devem ser solucionados no novo produto; além disso, evita o desenvolvimento de um produto que já existe, proporcionando ao usuário um produto aperfeiçoado em relação aos disponíveis.

Lobach (2001) destaca que a análise comparativa de produtos deve representar o estado real dos produtos existentes, determinar suas deficiências e valores, para estabelecer a melhoria possível do produto em desenvolvimento. A Figura 5 apresenta os coletores de urina para perna cedidos pela empresa x para a realização da análise. Foram analisados sete coletores que possuem capacidade para 500 $\mathrm{ml}(2,3,5$ e 7$)$, para $750 \mathrm{ml}$ (4 e 6) e para $2.000 \mathrm{ml}(1)$. 
Figura 5 - Análise sincrônica

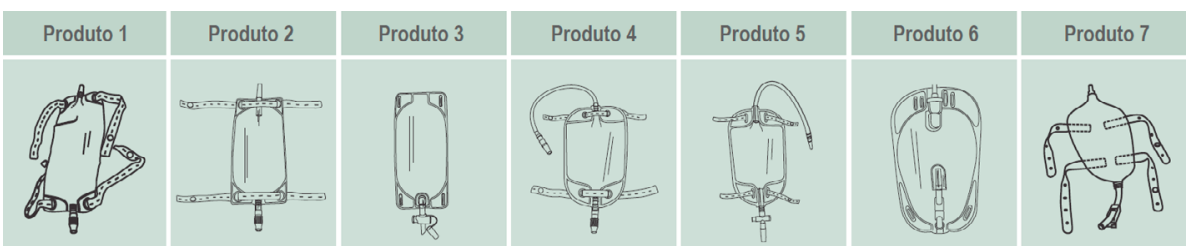

Fonte: elaborada pelos autores

A maioria dos coletores possui bolsas de PVC descartáveis e custa valores similares, com exceção do produto 7, que é feito de látex e é reutilizável, assim, possui custo mais alto em relação aos demais.

Os coletores apresentam pouca variação de cores, geralmente em tons frios. Embora as estruturas dos produtos sejam semelhantes entre si, pode-se destacar alguns componentes que exercem papel importante e, assim, estão presentes na estrutura do novo produto: o filtro de ventilação, a válvula antirrefluxo e o coldre protetor.

\section{Análise estrutural e funcional}

O objetivo das análises estrutural e funcional é reconhecer e compreender tipos e o número de componentes, subsistemas, princípios de montagem e tipologia das uniões, bem como os aspectos funcionais e de uso do produto que será desenvolvido (BONSIEPE, 1984).

Devido à semelhança estrutural dos coletores, essa análise teve como produto referência o coletor da marca Convatec (produto número 7 da análise sincrônica), considerado pela empresa $x$ aquele que possui as características mais próximas do desejado. Dessa forma, como mostra a Figura 6, a estrutura do coletor de urina para perna foi dividida em quatro subsistemas: (1) conector de sonda, (2) tubo extensor, (3) bolsa e (4) conector de saída, entre os quais alguns foram divididos ainda em subsubsistemas. 
A função principal do produto é armazenar a urina, cujo volume máximo é $500 \mathrm{ml}$. A função secundária do coletor de urina para perna é permitir a locomoção do usuário. A divisão dos subsistemas foi baseada na distribuição espacial dessas partes na estrutura como um todo e nas funções que exercem.

Figura 6 - Análise estrutural e funcional do coletor de urina para perna

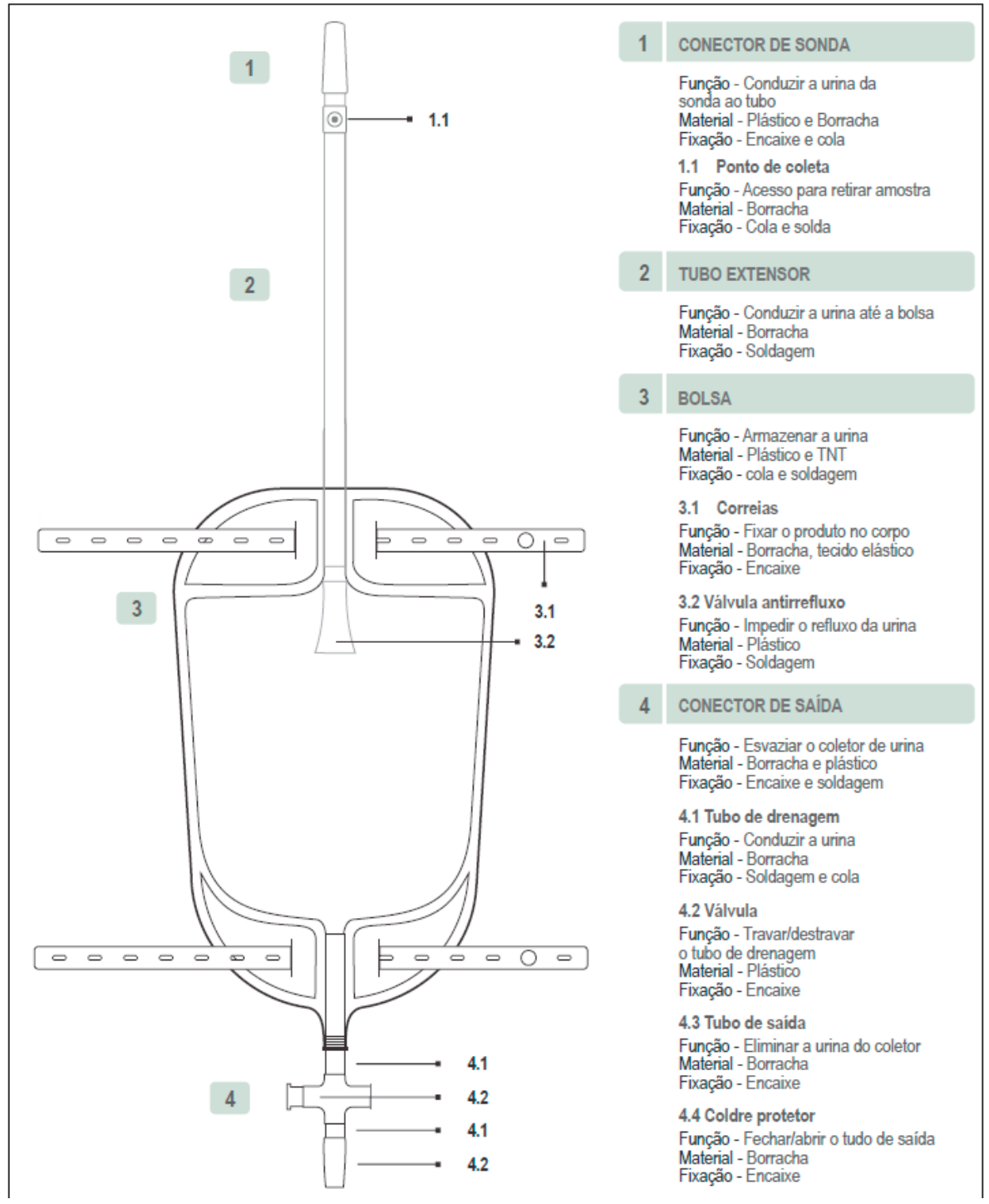

Fonte: elaborada pelos autores 


\section{Análise ergonômica}

Esta análise aborda requisitos de segurança, conforto e usabilidade do produto e possibilita a identificação das dificuldades do usuário ao utilizar o produto. A análise foi composta pela ordenação hierárquica das partes do produto (Figura 7), pela descrição da tarefa (Figura 8), pela definição das medidas antropométricas (Figura 9), pelo estudo de pegas e manejos (Figura 10) e pela definição dos requisitos e restrições da tarefa (Figura 11).

Figura 7 - Ordenação hierárquica

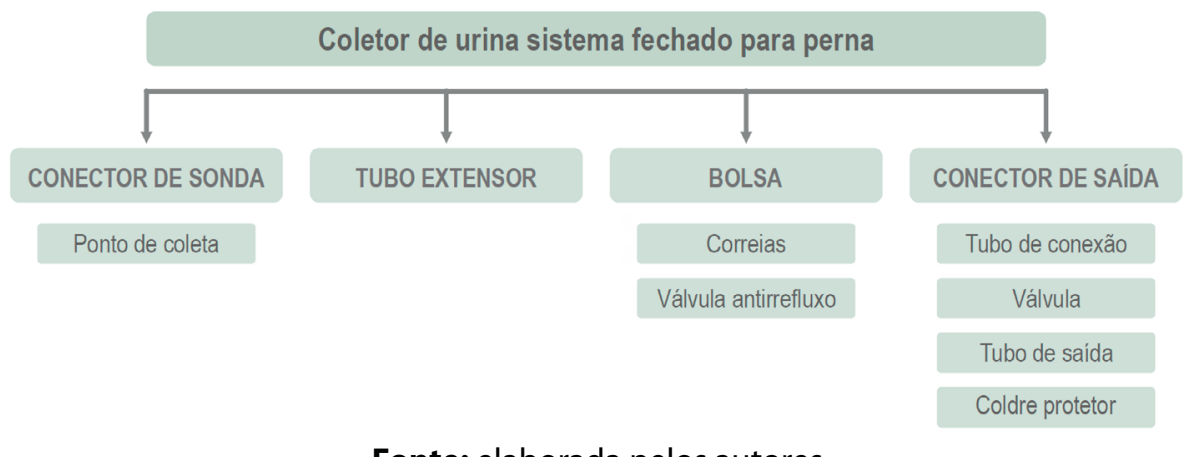

Fonte: elaborada pelos autores

Figura 8 - Descrição da tarefa

Objetivo
Utilização do coletor com
a finalidade de armazenar
a urina e permitir fáceis
locomoção e manuseio
para o usuário.

\section{Operadores}

Homens e mulheres, sem faixa etária especifica, com problemas no sistema urinário (retenção ou incontinência urinária).

\section{Condições operacionais}

O operador utiliza o produto realizando ações sentado ou em pé. O desconforto acontece porque o local onde o coletor fica acoplado (perna) fica longe dos membros que controlam seu uso - as mãos, forçando o usuário a dobrar o corpo para manuseá-lo.

Fonte: elaborada pelos autores

As dimensões do produto foram determinadas conforme as medidas antropométricas de homens e mulheres (Figura 9) de percentil 99, que abrange $99 \%$ da população. O tamanho do tubo extensor foi 
definido conforme o percentil 1, pois, como é fixo à perna, deve abranger desde o mínimo ao máximo tamanho.

Figura 9 - Medidas antropométricas

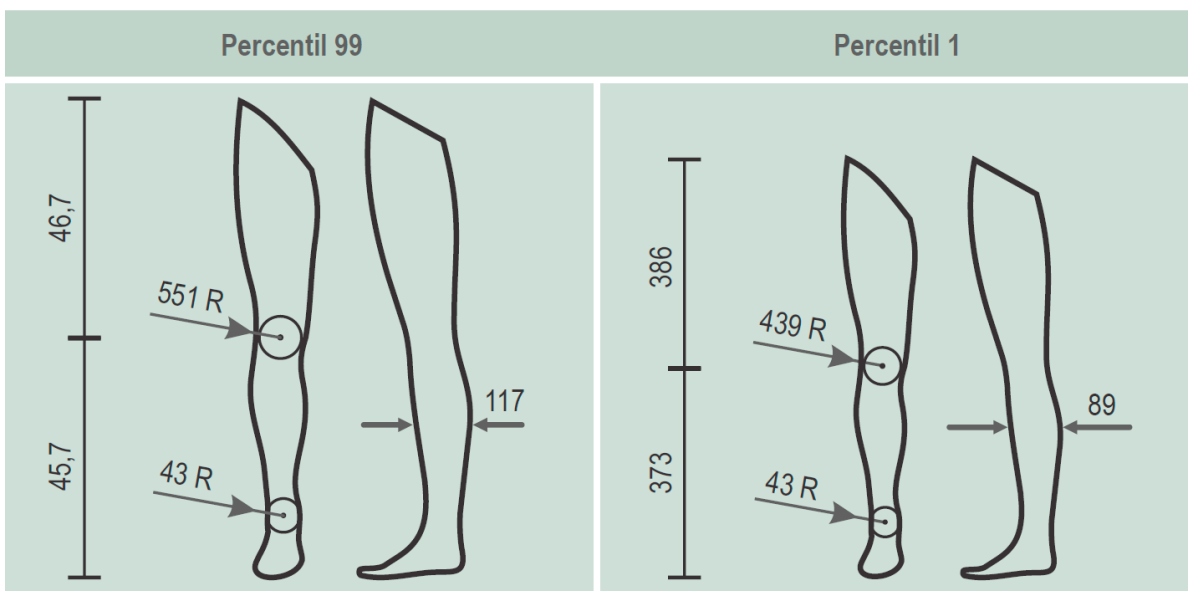

Fonte: elaborada pelos autores, baseada em Dreyfuss (2005)

Figura 10 - Análise de pegas e manejos

1 Acessar o coletor

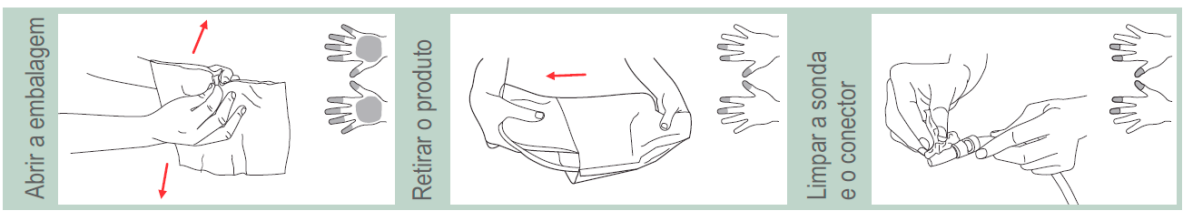

2 Vestir o coletor

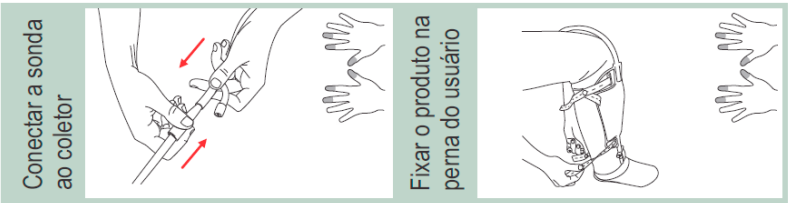

3 Esvaziar o coletor

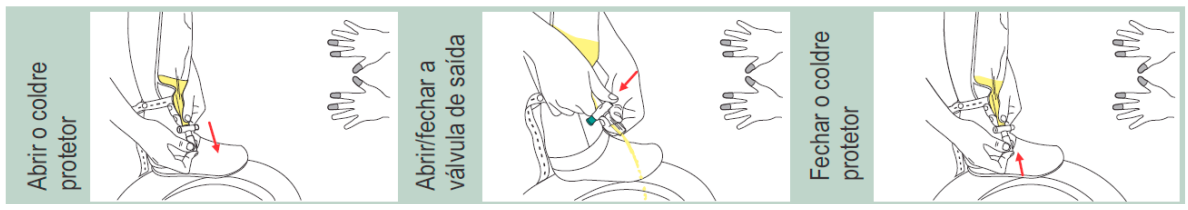

Fonte: elaborada pelos autores 
Os requisitos e restrições da tarefa (Figura 11) determinam, consecutivamente, o que o produto deve possuir para que a tarefa seja realizada com conforto e segurança pelo usuário e os fatores que podem dificultar a obtenção do produto ergonomicamente ideal.

Figura 11 - Requisitos e restrições da tarefa

\begin{tabular}{|c|c|}
\hline Requisitos & Restrições \\
\hline $\begin{array}{l}\text { - Aestrutura deve ter capacidade para } 500 \mathrm{ml} \text {. } \\
\text { - O produto deverá possuir uma estrutura que distribua de } \\
\text { maneira uniforme a urina, e que se mantenha estável com o } \\
\text { passar do tempo durente o uso do produto. } \\
\text { - As correias deverão ser reguláveis e antitranspirantes; } \\
\text { não devem provocar escaras, beliscões, nem problemas de } \\
\text { circulação e transferência de calor. } \\
\text { - O material deverá ser hipoalergênico; manter a } \\
\text { temperatura constante quando a urina é armazenada na } \\
\text { bolsa; impedira passagem de odor e vazamentos. } \\
\text { - o produto deverá ser adequado as medidas } \\
\text { antropométricas referenteao percentil } 97 \text {. } \\
\text { - O conector de saida deverá ser protegido do meio } \\
\text { externo. }\end{array}$ & $\begin{array}{l}\text { O material não ser de boa qualidade e desfavorecer a } \\
\text { estabilidade da bolsa. } \\
\text { - As correias causarem algum tipo de lesão para os } \\
\text { usúarios. } \\
\text { - A válvula de saída não vedar totalmente ocasionando } \\
\text { vazamentos. } \\
\text { - O conector de saída ficar exposto ao meio externo e } \\
\text { contaminarousuário. } \\
\text { - O material causaralergias ao usuário. } \\
\text { medidas antropométricas limitando os movimentos do } \\
\text { usuário. }\end{array}$ \\
\hline
\end{tabular}

Fonte: elaborada pelos autores

\section{Análise morfológica}

Os coletores possuem baixa complexidade em relação à forma. Como mostra a Figura 12, os coletores foram separados em dois grupos que diferem, basicamente, pela forma da bolsa -parte principal da estrutura, cuja configuração apresenta visíveis elementos geométricos, simetria, bidimensionalidade e leitura no sentido vertical. O primeiro grupo caracteriza-se por possuir estrutura retangular com arestas definidas, enquanto o segundo apresenta bordas arredondadas que deixam a estrutura mais orgânica em relação ao primeiro grupo. 
Figura 12 - Análise morfológica

GRUPO 1 | Produtos 1, 2 e 3

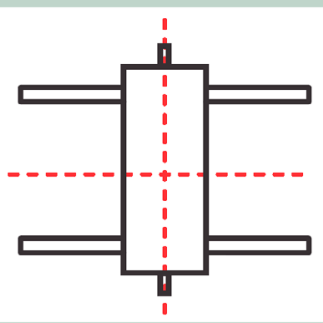

GRUPO 2 | Produtos 4, 5, 6 e 7

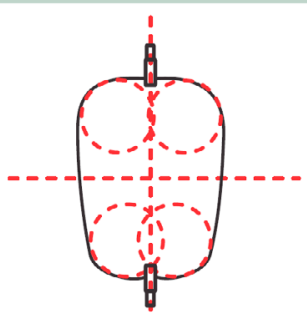

Fonte: elaborada pelos autores

\section{Análise da relação social, econômica e cultural do usuário e produto}

O público-alvo do produto abrange homens e mulheres que possuem algum problema no funcionamento do sistema urinário que levou à incontinência urinária. Os usuários podem apresentar ainda problemas no sistema neurológico que tenha afetado a locomoção. O produto é distribuído por hospitais e também pode ser adquirido em lojas de produtos médico-hospitalares. A Figura 13 apresenta produtos que indicam o estilo de vida do usuário, e a Figura 14 mostra diferentes representações físicas de possíveis usuários do coletor de urina para perna.

Figura 13 - Representação de produtos do usuário

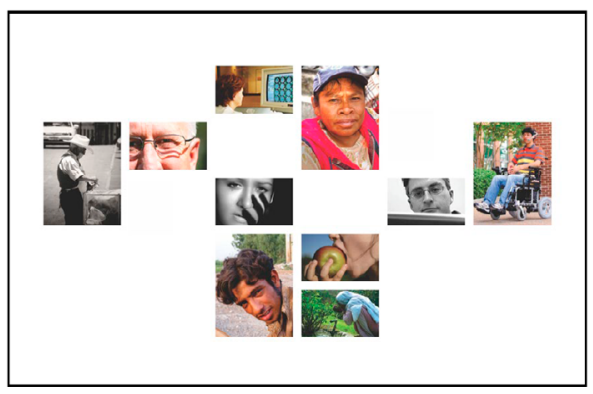

Fonte: elaborada pelos autores
Figura 14 - Representação do público-alvo

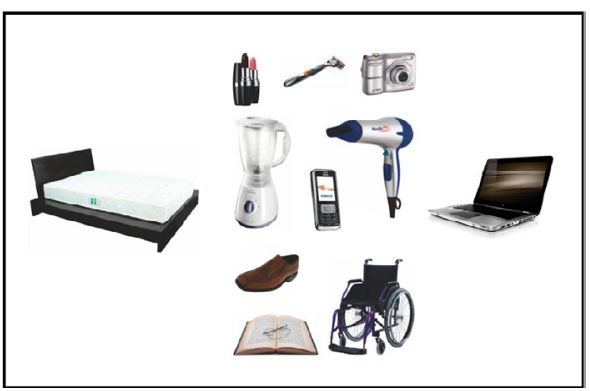

Fonte: elaborada pelos autores 


\section{Diretrizes do projeto}

Figura 15 - Diretrizes para o desenvolvimento do coletor de urina sistema fechado para perna

\begin{tabular}{|c|c|c|c|}
\hline ஜ्) & $\begin{array}{l}\text { - Utilizar correias que regulem. } \\
\text { - Utilizar a válvula de saída que obteve melhor } \\
\text { desempenho na análise da tarefa. }\end{array}$ & 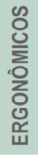 & $\begin{array}{l}\text { - Adequar as medidas antropométricas do percentil } 95 . \\
\text { - Possuir forma anatômica, adaptada à perna do usuário. }\end{array}$ \\
\hline 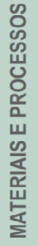 & $\begin{array}{l}\text { - Possuir materiais hipoalergênicos, isotérmicos e } \\
\text { impermeáveis. } \\
\text { - O conector de sonda, o tubo extensor e a válvula } \\
\text { de saida serão os determinados pela empresa X. } \\
\text { - Utilizar processos de fabricação, já presentes na } \\
\text { produção da empresa } X \text {, que vedem totalmente as } \\
\text { partes e as suas junçôes. }\end{array}$ & 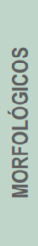 & $\begin{array}{l}\text { - As transições deverão ser cilindricas de modo que } \\
\text { conduzam a urina pelo coletor. } \\
\text { - Apresentar cores que transmitam sensação de limpeza. } \\
\text { - As partes serão configuradas de forma que a estrutura } \\
\text { final siga a orientação do corpo humano. }\end{array}$ \\
\hline 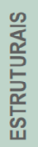 & $\begin{array}{l}\text { - A bolsa deverá possuir divisórias que } \\
\text { mantenham a urina distribuida uniformemente. } \\
\text { - O produto deverá conter todas as partes fixas a } \\
\text { sua estrutura principal. }\end{array}$ & 总 & $\begin{array}{l}\text { - Utilizar símbolos que indiquem como o produto } \\
\text { será utilizado. } \\
\text { - O conector de saída deverá possuir indicação de } \\
\text { uso. }\end{array}$ \\
\hline
\end{tabular}

Fonte: elaborada pelos autores

\section{REALIZAÇÃO DO PROJETO DE PRODUTO MÉDICO-HOSPITALAR: DESENVOLVIMENTO DO COLETOR DE URINA PARA PERNA}

Foram realizadas as seguintes atividades durante o processo criativo:

Primeiramente foram feitos rabiscos desordenados em busca de novas formas-técnica conhecida por graforrismo que gerou vários módulos utilizados posteriormente nos conceitos; as operações elementares de desenho estavam presentes na geração de algumas alternativas (Figuras 16 e 17). Em seguida foram buscados na natureza animais com estrutura semelhante ao do coletor de urina; essas estruturas foram decompostas em formas básicas - círculos, quadrados e triângulos-para assim originar novas formas, que são os conceitos e suas variações (Figuras 18). 
Figura 16 - Desenvolvimento do conceito 1
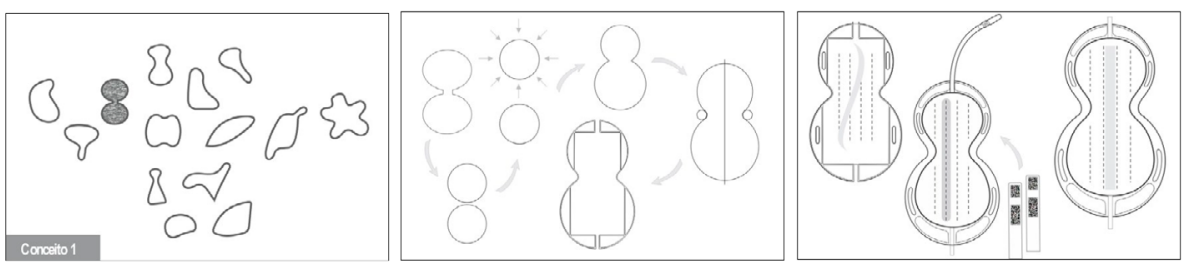

Fonte: elaborada pelos autores

Figura 17 - Desenvolvimento do conceito 2
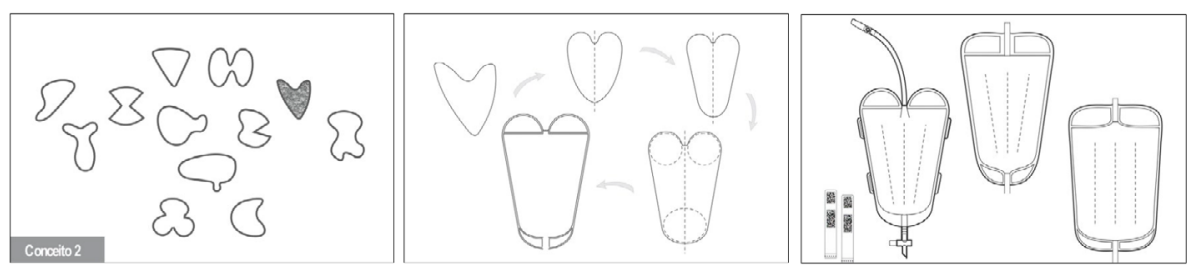

Fonte: elaborada pelos autores

Figura 18 - Desenvolvimento do conceito 3

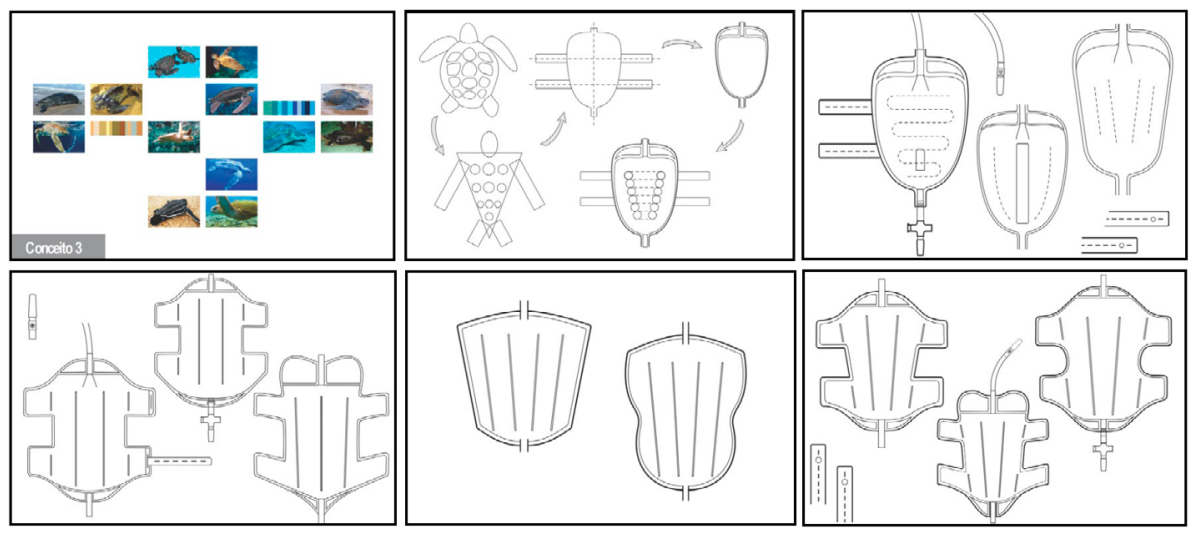

Fonte: elaborada pelos autores

Foi realizada uma pesquisa com profissionais da área de física para entender a ação da gravidade e o equilíbrio das forças atuantes 
para que o produto fosse deslocado o mínimo possível durante o uso. Também pelo fato do produto ser considerado um sistema de vasos comunicantes (i.e. recipiente formado por diversos ramos que se comunicam), foi preciso verificar qual o espaço mínimo entre os vasos para que a urina pudesse ser distribuída igualmente pela bolsa.

Após gerar algumas formas foi necessário testar os volumes para confirmação dos cálculos realizados por meio de fórmulas de volumes cilíndricos e tronco de cone. Os conceitos foram desenhados em tamanho real e em seguida foram produzidos modelos de plástico para teste do volume, simulando as formas das bolsas com as soldas. Os testes também possibilitaram observar o comportamento das soldas e a reação da estrutura com a entrada de água e definir o espaço para a comunicação das partes divididas pelas soldas. Foi produzido um modelo antropométrico (perna de isopor), com medidas do percentil 99, para observar a localização da bolsa na perna do usuário e testar os tamanhos limites.

\section{Conceito escolhido}

O conceito 3 foi selecionado por apresentar o maior número de características pertinentes aos requisitos do projeto. $O$ conceito foi fundamentado na biomimética a partir do estudo de formas e outros aspectos da natureza, que serviram de inspiração para o desenvolvimento do projeto. Considerando que a estrutura do produto é semelhanteà maioria dos animais quadrúpedes, o ambiente marinho foi selecionado para delimitar as espécies envolvidas. Em seguida, foram buscados os significados de alguns desses animais. Observou-se que os significados atribuídos a tartarugas-estabilidade, longevidade, paciência e resistência-eram coerentes tanto em relação ao produto quanto ao usuário. Assim, a tartaruga foi selecionada, e suas formas básicas-círculos, triângulos e quadrados, foram 
modificadas, originando a nova forma do coletor de urina e suas variações. Partindo do conceito 3, foram desenvolvidas alternativas, que evoluíram conforme os resultados dos testes volumétricos; assim, a variação 11 foi a estrutura selecionada (Figura 19).

Figura 19 - Conceito 3 variação 11

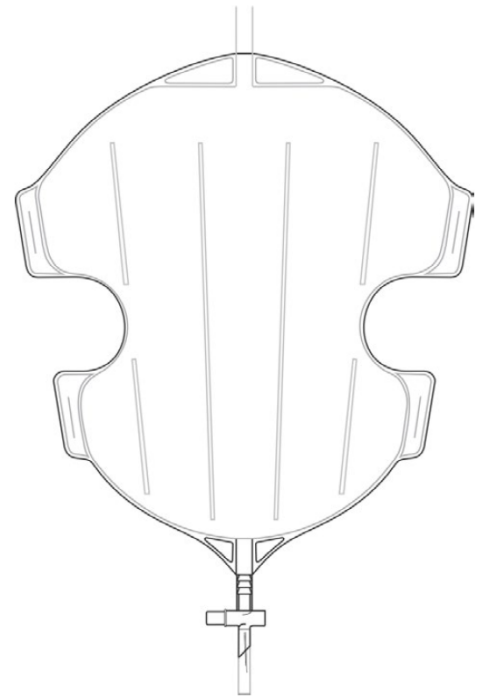

Fonte: elaborada pelos autores

A estrutura do conceito escolhido segue a mesma orientação do corpo humano, ou seja, orientação vertical com correias na direção horizontal, sendo a parte superior maior que a inferior, assim como a forma da perna humana. Possui formas e bordas arredondadas que atribui à estrutura configuração ergonômica, adaptando-se melhor ao corpo do usuário. $O$ conceito escolhido atende aos requisitos do projeto e apresenta o equacionamento dos fatores ergonômicos, perceptivos, tecnológicos e econômicos que determinam um produto bem solucionado.

Definiu-se que a bolsa deve possuir partes soldadas para melhor distribuir o líquido e evitar a dilatação da bolsa. Ao distribuir 
uniformemente o líquido (ver Figura 20), o usuário utilizará o produto com mais conforto, uma vez que o peso da urina será distribuído e diminuirá o deslocamento das correias. Como a bolsa pode dilatar-se até determinado ponto, será mais confortável para o usuário utilizála por baixo da calça, ficará menos perceptível. A parte frontal da bolsa é feita de PVC branco e possui uma área transparente para o monitoramento da urina.

As áreas soldadas da bolsa (Figura 20) solucionam importantes problemas detectados durante a análise da tarefa, no entanto, limitam o espaço que o líquido vai ocupar na bolsa, já que limitam a dilatação. Assim, as variações foram evoluindo de acordo com esse fator determinante. Durante o desenvolvimento das alternativas foram produzidos modelos para testar os espaços das bolsas, sendo necessário o espaço para volume de $500 \mathrm{ml}$.

Figura 20 - Conceito 3

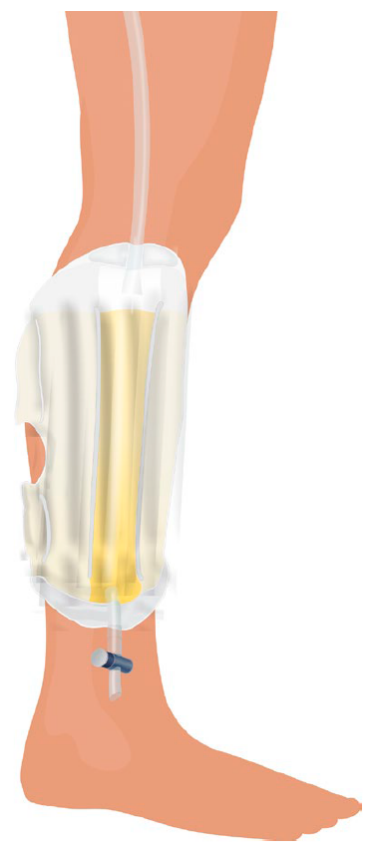

Fonte: elaborada pelos autores 
Pode-se perceber que nesse conceito a forma torna-se mais ergonômica, e também pelo fato do espaço ser maior que do que nas bolsas anteriores, já que o líquido pode ocupar ainda os espaços laterais.

Figura 21 - Modelo final do coletor de urina sistema fechado para perna

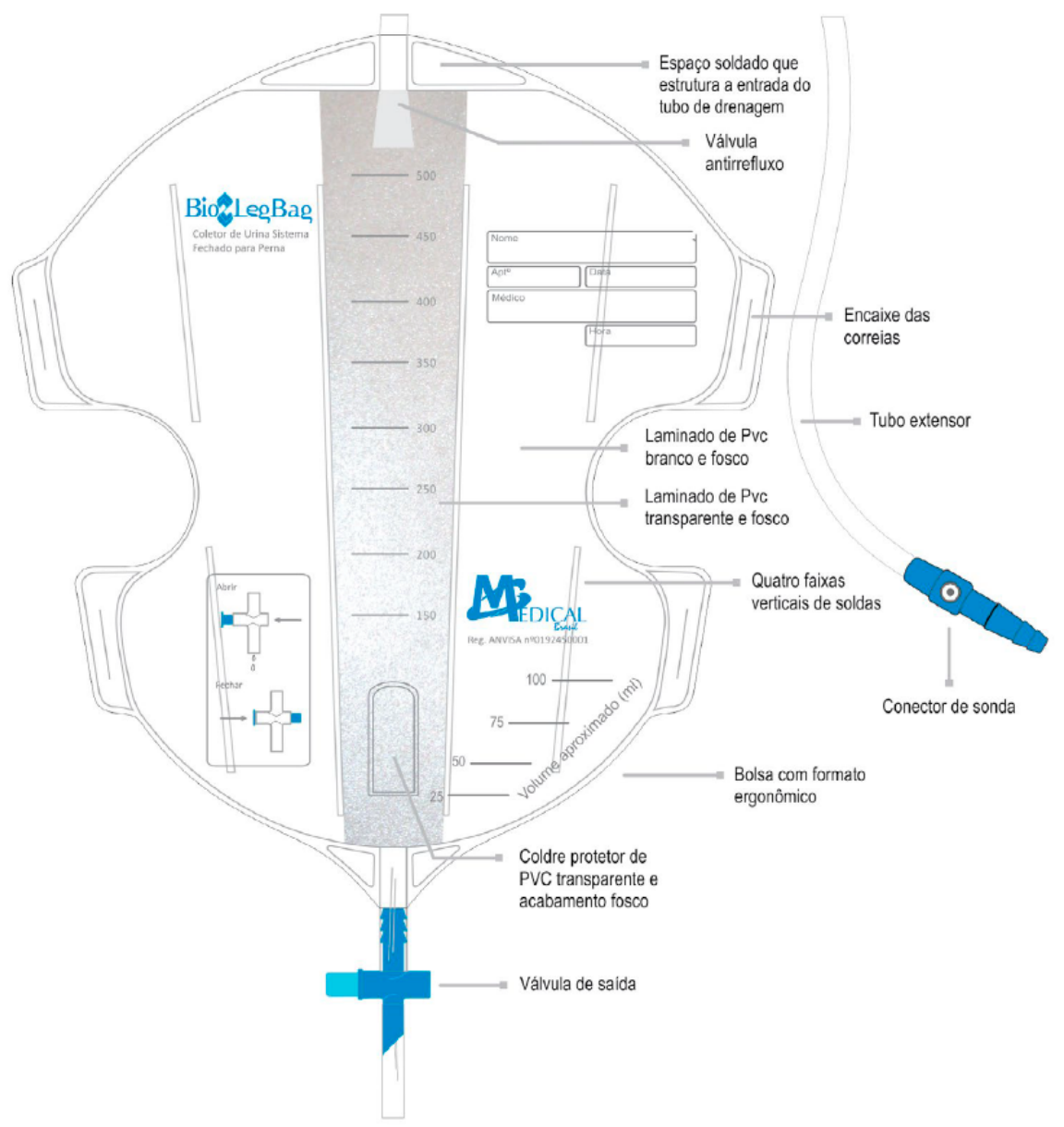

Fonte: elaborada pelos autores 


\section{REFERÊNCIAS}

ANVISA. Medidas de Prevenção de Infecção Relacionada à Assistência à Saúde. 2013. Disponível em: <http://www20.anvisa. gov.br/>. Acesso em: 14 mai. 2014.

Athikson e Murray. Fundamentos de Enfermagem: introdução ao Processo de Enfermagem. Rio de Janeiro: Guanabara, 1989.

BONSIEPE, G. Metodologia experimental - desenho industrial. Brasília: CNPQ/Coordenação Editorial, 1984.

BRITO, A. Ampliação do Vocabulário em Desenho Industrial: considerações para projeto de produto. 2004. 123 f. Dissertação (Mestrado em Engenharia de Produção) - Universidade Federal de Santa Maria, Rio Grande do Sul, 2004.

CONTTENDEN, A.; BLISS, D.; BUCKLEY, B.; FADER, M.; GETLIFFE, K.; PATERSON, J.; PIETERS, R.; WILDE, M. Management Using Continence Products, 2009, Paris. Proceedings... Paris: Editions 21, 2009.

DREYFUSS, Henry. As Medidas do Homem e da Mulher. Porto Alegre: Bookman, 2005.

GOULD, C.; UMSCHEID, C.; AGARWAL, R.; KUNTZM G.; PEGUES, D. The Healthcare Infection Control Practices Advisory Committee. 2009. Disponível em: <http://www.cdc.gov/>. Acesso em: mar. 2015.

LOBACH, Bernd. Diseño Industrial. Barcelona: Gustavo Gilli, 2001.

MAKI, D.; TAMBYAH, P. Engineering Out the Risk for Infection with Urinary Catheters. Emerging Infectious Diseases. [S. I.], v. 7, n. 2, p. 342-347, 2001. 
SCHULTHEISS, Dirk. A Brief History of Urinary Incontinence and its Treatment. Disponível em: <http://www.icsoffice.org $>$. Acesso em: 20 ago. 2014. 



\section{Design industrial na Whirlpool Latin America: filosofia e resultados}

Fernando Pereira Pruner (Currículo Lattes)

\section{INTRODUÇÃO: WHIRLPOOL S.A.}

Tendo iniciado suas atividades nos Estados Unidos em 1911 como Upton Machine Company, a Whirlpool Corporation opera na América do Sul com as marcas Brastemp, Consul, Whirlpool, Eslabon de Lujo e KitchenAid.

Em 2013, a Whirlpool faturava US\$ 19 bilhões, empregava 69.000 pessoas e possuía 59 unidades espalhadas pelo globo. $\mathrm{Na}$ América do Sul e Central, eram 14.800 colaboradores, espalhados pela sede e diversas unidades, escritórios e centros de distribuição.

Especificamente quanto ao design industrial, a empresa possui estúdios nos Estados Unidos, México, Brasil, Itália, Índia e China, 
totalizando mais de 250 pessoas. No Brasil, são 10 pessoas em Rio Claro (SP) e 35 pessoas em Joinville (SC). A equipe é em sua maioria composta por designers de produto, gráfico e de interface. Mas também participam engenheiros de alimentos, psicólogos e jornalistas.

\section{POSICIONAMENTO FILOSÓFICO}

Se por um lado o mundo em mudança é uma constante, por outro duas abordagens desde há muito tempo são fundamentais para nortear o posicionamento da área de design da Whirlpool Eletrodomésticos.

A primeira trata da proposta de Platão quanto às arenas da sociedade, a saber:

1. A verdade, isto é, a visão cognitiva e objetiva ou perspectiva positivista, dominante na ciência;

2. O bem, ou seja, a visão ética normativa ou a perspectiva moral, que é dominante nas organizações espirituais ou judiciárias e;

3. O belo, isto é, a visão expressiva ou impressionista, também entendida como a perspectiva estética, dominante nas artes.

O campo da ciência organizacional tem, tradicionalmente, colocado toda ênfase na primeira perspectiva, como, por exemplo, na administração científica, na tomada de decisão racional e na assertiva de que medir é saber. Adicionalmente, a perspectiva moral tem cada vez mais relevância, na forma do gerenciamento da qualidade, da sustentabilidade (pessoas, planeta e lucro), da cidadania corporativa e da ética. Entretanto, as pessoas procuram pelo belo tão intensamente como buscam métodos instrumentais e moralmente aceitáveis. Como consequência, a compreensão da lógica interna das teorias organizacionais, assim como de sua efetividade e impacto, deve ser ampliada para se tomar a dimensão estética em consideração 
(AKKERMANS; LAMMERS; WEGGEMAN, 2004). As corporações aprenderam que produzir com qualidade e agir eticamente não são mais suficientes para garantir a competitividade. E é o design que, além de trazer todo o conteúdo da estética para a corporação, deve também ser capaz de integrá-lo à estrutura existente.

A segunda abordagem está relacionada ao conceito grego de conhecimento, que era diferente da compreensão atual. Aristóteles tentou sistematizá-lo e, de maneira geral, distinguiu três diferentes competências, que se relacionam e interagem com três práticas do conhecimento, formando pares. É importante manter em mente a ênfase na prática como parte integrante do conhecimento (JOHANSSON; SVENGREN, 2004).

No primeiro par, episteme era a competência que consistia na criação do conhecimento sem motivo anterior, conhecimento por si só, isto é, conhecimento desinteressado. A essa competência correspondia a prática da teoria. A teoria pressupunha a episteme e por meio de sua execução era desenvolvida.

Havia o segundo tipo de conhecimento, representado por phronesis e práxis. Phronesis significava a capacidade ou competência da sabedoria prática e práxis era o processo de colocar esta competência em ação. Phronesis também pode ser descrito como a capacidade de fazer julgamentos éticos, e práxis seria o processo pelo qual essa capacidade é expressa em ação. Por meio da interação circular entre phronesis e práxis, ambos se desenvolvem como elemento-chave da sociedade. Essa forma de conhecimento reflete-se na boa cidadania.

A terceira forma de conhecimento era chamada techne e poiesis. Techne era a competência e a capacidade de produtivamente criar coisas. A essa competência criativa correspondia a poiesis, o processo em si de criar as coisas. 
A palavra tecnologia deriva, etimologicamente, do grego techne que incluía dois aspectos que estavam intrinsecamente ligados: a habilidade do trabalho e a arte, pois a ideia da produção estética sempre estava associada ao trabalho manual dos artesãos de então.

O termo techne, portanto, tinha um sentido diferente do atual e estava conectado à criação das coisas, sempre considerando o que hoje se entende como um somatório de arte e técnica. É nesse contexto que o design se insere, não sendo propriamente arte nem tecnologia. Ao transitar entre um e outro, traz novos componentes às corporações: o belo, a estética, a experiência. $O$ design deve então ter uma postura mediadora, trazendo a perspectiva da arte para a corporação, mas também a equilibrando com outros fatores, como tecnologia, mercado, capacitações fabris e de suprimentos, por exemplo.

A inserção da arte, por meio do design industrial, no contexto corporativo visa trazer maior competitividade. Abordar as pessoas, cada vez mais dispersas e com maior acesso à informação, só será possível se elas se sentirem únicas, se sentirem que determinada marca pensou em cada uma delas, respeitando-a na sua individualidade. $E$, por seu lado, a marca em si deve transmitir sua aura de unicidade, de peculiaridade. Afinal, nosso cérebro foi projetado para identificar o que é único, diferente, exclusivo.

A construção dessa individualidade se dá, entre diversos fatores, por meio dos produtos com os quais as pessoas se cercam. Entretanto, mais que os produtos, as pessoas compram os seus significados. Este último, no reino corporativo, é domínio do design industrial.

Um iPod, por exemplo, além de um tocador de música, tem em si mesmo a representação da individualidade. A coleção de músicas de alguém, suas preferências e estilos estão todos guardados ali. Dividir 
uma playlist é um grande movimento no sentido de compartilhar essa individualidade, de compartilhar algo íntimo com outra pessoa.

Em outro exemplo, como as motocicletas Harley Davidson e BMW, produtos similares têm significados totalmente diferentes. Enquanto as primeiras representam liberdade e até transgressão, as segundas remetem a conforto e tecnologia.

Um sorvete da marca Häagen-Daaz, com seu nome exótico, mas de origem americana, nos traz a imagem de indulgência, um exagero a se presentear.

Em comum esses exemplos têm o fato de liderarem suas indústrias e de serem notórios na mente de consumidores no mundo todo. Não é uma coincidência.

Essa é uma proeza no mundo dos negócios extremamente difícil de realizar, e quanto mais ortodoxos os executivos, mais distantes da resposta a empresa se encontra. Afinal, como vender o café, que custa $R \$ 400,00$ a saca de $60 \mathrm{~kg}$ e que é vendido a $R \$ 9,00$ o pacote de $500 \mathrm{~g}$ no supermercado, por mais de $\mathrm{R} \$ 300,00$ o quilo? Simples, invente um novo negócio chamado café em cápsulas, ou Nespresso.

Cabe ao design criar produtos que despertem no consumidor emoções e memórias para promover o desejo por estes mesmos produtos, não apenas pelo seu aspecto ou utilidade, mas por conter propriedades cada vez mais intangíveis, que proponham uma experiência. É nesse sentido que o design se aproxima da arte.

Em outras palavras, em um exemplo simples, é preciso competir com Fernando de Noronha. Afinal, as pessoas têm preferido viver uma experiência gratificante, que lhes impregna os sentidos e que permanecerá na memória, a comprar um eletrodoméstico. 


\section{POSICIONAMENTO ESTRATÉGICO}

A área de Design da Whirlpool entende que é preciso ser importante para as pessoas. É preciso causar um impacto positivo, trazendo o conteúdo da arte e da estética para as corporações. É esse nível de experiência que conecta as pessoas com as marcas e torna a função design imprescindível.

Para tal, converte sua postura filosófica e a organiza no seu posicionamento estratégico, que tem cinco perspectivas:

1. Surpreender as pessoas no momento da compra e no uso cotidiano, buscando uma profunda compreensão dos direcionadores da satisfação em ambas as esferas;

2. Criar produtos e soluções com os quais as pessoas se identifiquem, na sua forma, na sua função, na experiência que provoca, no seu significado;

3. Antecipar o futuro, procurando antever os anseios e necessidades das pessoas;

4. Traduzir os aspectos sociológicos para que os produtos sejam compreendidos pelas pessoas e que possam gerar uma conexão positiva;

5. Garantir a tradução correta do posicionamento de cada marca da companhia.

É dessa forma que o Design se assegura de fazer uma contribuição efetiva como disciplina no contexto corporativo, apropriando-se de um conteúdo exclusivamente seu. Assim, passa a ser um direcionador estratégico da inovação e da identidade de marca, conectado ao cerne da companhia. 


\section{INSPIRAÇÃO NÃO, CONHECIMENTO SIM}

Não há bola de cristal. Existe um trabalho sistemático de geração de conhecimento e sensibilização contínua da equipe envolvida no desenvolvimento do design. Todos são estimulados a monitorarem cenários sociais e tecnológicos, gerando apresentações e conclusões. As mais diversas ferramentas da gestão do conhecimento são usadas para se conectar ao consumidor, para conhecê-lo profundamente, e gerar a experiência correta no produto que se desenvolve.

Os designers utilizam os produtos existentes, visitam consumidores, participam da preparação da refeição, do ato de guardar os alimentos depois das compras, acompanham o lavar e estender de roupas. Fotografam casas e pessoas, construindo mapas referenciais que ajudam a desenvolver produtos adequados às necessidades e surpreendentes ao antecipar soluções.

Especialistas também são convidados a participar de eventos: chefes de cozinha, nutricionistas, engenheiros de alimentos e outros profissionais trazem a sua contribuição para a construção de uma ampla base de conhecimento. E não para por aí: especialistas em iluminação e em som, blogueiros, fornecedores, outras indústrias, institutos de pesquisa e internet são fontes também exploradas.

O conhecimento das mais diversas áreas - consumidor, usuário, mercado, marca, tecnologia, tendências, entre outros - é responsável por enriquecer o processo criativo, tanto ao acelerar a geração de alternativas quanto ao ajudar a prover um número maior de alternativas geradas, e também ao assegurar maior assertividade das propostas.

Ao se iniciar o processo de desenvolvimento de produto é preciso primeiro usar do pensamento divergente, isto é, prover a organização com alternativas, opções, caminhos a seguir. Uma 
vez que se criam as escolhas, é possível fazer escolhas - divergir e convergir.

Os workshops criativos são frequentes no Design Whirlpool. A equipe se reúne para debater o conhecimento acumulado, avaliar as premissas do projeto e, em conjunto, gerar uma grande quantidade de opções e soluções para o problema proposto. Não é uma questão de quantidade, somente. Mas sim de quantidade na direção correta.

Esse é um processo iterativo que permite explorar a descoberta, estimular o pensamento criativo e encontrar novas maneiras de abordar os problemas. $\mathrm{E}$, em muitos casos, até mesmo redefinir o problema.

\section{CONCLUSÃO: EXEMPLOS E CASOS}

A seguir se apresentam alguns exemplos da conversão do posicionamento filosófico e estratégico, por meio do conhecimento, em produtos efetivamente lançados no mercado.

Mais que um armário gelado, a geladeira é a central de mensagem da casa, decorada com bilhetes e imãs de tele-entrega. Com base nessa constatação, a equipe de Design começou a buscar soluções que encantassem os consumidores, como, por exemplo, um gravador de voz que pudesse armazenar 3 a 5 mensagens. Entretanto, o melhor conceito surgiu após uma reunião com o fornecedor de tintas, que se dispôs a desenvolver o substrato igual ao de quadro branco, mas com a resistência requerida pelos testes da empresa.

$O$ resultado foi tão inovador e surpreendente que o parceiro responsável pelas canetas assumiu todos os custos do seu desenvolvimento para estar associado a essa ideia e visando a receita recorrente com a venda de novas canetas. 
Uma das dúvidas mais frequentes, especialmente entre usuários iniciantes, é a relação correta entre quantidade de roupa, de sabão e nível de água em lavadoras de roupas. $\mathrm{E}$ a solução pode ser algo tão simples quanto uma marcação numérica que correlacione as funções.

A lavadora de roupas "Nível Fácil" da Consul possui uma escala na parede do cesto, outra no reservatório de sabão e uma terceira no manípulo seletor de nível de água. O usuário deve colocar a quantidade de sabão e definir o nível de água de acordo com o espaço ocupado pela roupa dentro do cesto.

A marca Brastemp, dado o seu reconhecimento, permite explorações em novos segmentos de mercado por meio da criação de produtos pouco convencionais. Uma dessas explorações foi de produtos retrô, aproveitando a tendência mundial nesse sentido. A primeira série de produtos foram refrigeradores compactos lançados em 2005, até hoje disponíveis no mercado.

O sucesso dessa iniciativa deu origem a mais duas linhas de produtos retrô: as geladeiras duplex no frost e os fogões 4 bocas.

A Brastemp também inovou ao lançar, em 2001, uma linha completa de refrigeradores personalizáveis. O consumidor poderia escolher diversos componentes internos, se o produto teria água na porta, tipo de controle eletrônico e ainda uma entre dezenas de cores disponíveis. Eram mais de 14.000 combinações possíveis. Até o ano passado, quando foi descontinuada, a linha personalizável YOU compreendia, além do refrigerador, de um fogão de mesa e de uma lavadora de louças.

Outra iniciativa inovadora (e também de expansão de marca) da Brastemp foi a entrada no mercado de purificadores de água, com a peculiaridade de modelo de negócio por meio de assinatura. Em outras palavras, o produto não é vendido, mas alugado por uma taxa 
mensal. A empresa instala o aparelho e se responsabiliza pela sua manutenção e limpeza periódica. Em caso de desistência, recolhe o produto que tem então sua destinação adequada. Esse produto, e seu modelo de negócio, é um caso de sustentabilidade-alvo de diversos estudos.

Tendo iniciado esse empreendimento em 2006, o filtro de água encontra-se hoje na sua segunda versão, com desenho mais contemporâneo, acionamento eletrônico e inclusão de teclas em relevo "braille".

Em 2013 a marca lançou o primeiro refrigerador com três portas fabricado no Brasil. Sua configuração peculiar, com o freezer na parte inferior e duas portas lado a lado no refrigerador, é complementada por uma interface similar a um tablet. Com conexão sem fio à internet $\mathrm{e}$ aplicativos, o produto possui uma série de funcionalidades, incluindo lista de compras compartilhada pela família.

A marca Consul, por sua vez, vem apresentando inovações ligadas ao dia a dia das pessoas, notadamente com um posicionamento mais jovem. Um exemplo é o forno micro-ondas que possui uma sanduicheira capaz de tostar o pão, deixando-o crocante como no forno tradicional.

Outro exemplo é a cervejeira, um refrigerador com capacidade para até 75 latinhas, que não precisa descongelar, tem visor de vidro e mostrador de temperatura, similar aos modelos encontrados em bares.

E a mais recente inovação vem com a marca Brastemp: uma máquina de bebidas em cápsulas. Trata-se de um purificador que serve água quente, natural, fria e gelada, com ou sem gás. Também é possível inserir cápsulas que permitem a elaboração de mais de 20 sabores, entre chás, café, sucos e refrigerantes. 


\section{REFERÊNCIAS}

AKKERMANS, H. A.; LAMMERS, I.S. ;WEGGEMAN, M. C. D. P. All ye need to know? Aesthetics from a design perspective. Eindhoven Centre for Innovation Studies, eindhoven, 2004.

JOHANSSON, U. ; SKÖLDBERG, K. ; VENGREN, L. Industrial design as a balancing artistry: some reflections upon industrial designer's competence. 2004. Barcelona, European Academy of Design. 



\section{Rota segura para dias de inundações: desenvolvimento de elementos visuais para auxiliar na locomoção, alertas e localização da população}

Jean Fabyano Andrighi (Currículo Lattes) Virginia Grace Barros (Currículo Lattes)

\section{METODOLOGIA DE DESIGN APLICADA}

Para alcançar os objetivos propostos, o processo de pesquisa foi organizado conforme a metodologia para Sistema de Informação para Wayfinding (SIW) proposta por Calori (2007). Essa metodologia foi adaptada para atender ao estudo em questão. Para o presente projeto de pesquisa foram utilizadas as etapas de pré-design e design. Segundo Scariot (2013, p. 70), o pré-design consiste na coleta de todas as informações necessárias para o aprendizado e descoberta de aspectos específicos do projeto. Assim sendo, o pré-design se caracterizou pela fundamentação teórica do projeto em questão, apresentando os contextos relacionados aos riscos socioambientais 
e inundações no ambiente urbano, de que forma esses eventos afetam o município de Joinville (especificamente a área da bacia hidrográfica do rio (achoeira-BHRC), além de como surgiu e funciona o projeto Rota Segura para Dias de Inundações (RSDI). No segundo momento foram contextualizados os assuntos relativos à Wayfinding, sinalética, Design (informação e sinalização) e sinalização (normas e leis), os quais contribuem para reflexões acerca do tema em estudo.

A etapa de design apresenta duas subdivisões: o design esquemático e desenvolvimento de design. $O$ design esquemático consiste na determinação de locais a serem sinalizados e da função que se deseja com cada elemento da sinalização, gerando um esquema ou inventário preliminar do sistema. Nesse sentido foi possível ter uma visão geral do projeto, plano de localização dos elementos de sinalização (peças), hierarquia das mensagens, opções de tipografia, símbolos, contexto visual de cada peça, estudos básicos de modelos, formas e formatos, entre outros (SCARIOT, 2013). O design esquemático na pesquisa em foco analisou tanto a RSDI desenvolvida pela Defesa Civil quanto a BHRC a fim de chegar a um entendimento sobre como se comporta a mancha de inundação nessa área. Por meio dessa análise definiu-se uma área de estudo dentro da BHRC para a aplicação da proposta de sinalização. Posteriormente, diferentes mapas do Sistema Municipal de Informações Georreferenciadas (SIMGeo) foram cruzados (focados no recorte pré-estabelecido e no mapa da RSDI) e assim foram definidos os pontos a serem sinalizados, bem como quais seriam as sinalizações adequadas para cada situação. Esse processo foi acompanhado pela Defesa Civil de Joinville e apresentado ao Instituto de Pesquisa e Planejamento Urbano de Joinville (IPPUJ) e Departamento Municipal de Trânsito de Joinville (DETRANS-antigo Instituto de Trânsito e Transporte de Joinville-ITTRAN), os quais 
contribuíram com apontamentos e sugestões a partir de experiências técnicas/campo, possibilitando novas visualizações, alterando certos aspectos anteriormente definidos. A partir de tais análises foi iniciada a geração de alternativas, nomeada de desenvolvimento de design, que segundo Scariot (2013) corresponde à geração de alternativas, a partir da qual os fundamentos e informações visuais são formatados. Posteriormente as melhores alternativas são definidas e refinadas para representar o SIW. O desenvolvimento de design tem como objetivo apresentar o plano de localização final das peças, o inventário final de mensagens, os desenhos finais das peças gráficas e físicas e as especificações técnicas, entre outros.

\section{PRÉ-DESIGN}

O crescimento urbano é um fenômeno mundial. Nesse contexto, a constante ocupação das cidades por suas diferentes estruturas artificiais (estradas, ruas, casas, edifícios, indústrias etc.), em áreas que anteriormente eram reservadas ao meio ambiente natural, geram diversos problemas socioambientais, tais como poluição, doenças, falta de água, calor excessivo, inundações, entre outros. Em 1900, 13\% da população mundial era urbana, atualmente este percentual chega a 50\% (MULLER et al., 2012a). No Brasil, segundo Instituto Brasileiro de Geografia e Estatística (IBGE), as áreas urbanas possuem 23 milhões de habitantes e comportam $84,4 \%$ da população do país (SOUZA, 2013). As cidades muitas vezes são construídas sobre locais inadequados do ponto de vista urbanístico e ecológico. A esse respeito, Barbosa (2013) aponta que desastres naturais como enchentes, inundações e deslizamentos têm aumentado consideravelmente nas últimas décadas. $O$ processo de ocupação urbana não respeita o meio ambiente natural, englobando 
rios (aterrados ou canalizados), vegetação (derrubada), terrenos (impermeabilizados), encostas (ocupadas de maneira irregular), sem mencionar a poluição que contamina o solo e leito de diversas formas.

Nos últimos dez anos cerca de 250 milhões de pessoas foram afetadas por inundações e enchentes, sendo esses os riscos socioambientais mais generalizados e crescentes nas cidades ou assentamentos urbanos de diferentes tamanhos (UN/ISDR, 2013). Conorath (2012, p. 18) destaca que, “[...] ao redor do mundo, as inundações são responsáveis por $55 \%$ de todos os desastres registrados e por 72,5\% das perdas econômicas".

No Brasil, segundo Pizza (2013), 33 milhões de pessoas foram expostas a riscos de inundações até 2012, um número que poderá chegar a 43 milhões até 2030. O autor salienta ainda que as perdas econômicas promovidas por tais ocorrências poderão aumentar de US\$ 1,4 bilhão para US\$ 4 bilhões por ano, em menos de 20 anos, no Brasil. Comparadas com os dez anos anteriores, as ocorrências de desastres naturais no Brasil cresceram 268\% na década de 2000. As inundações foram o evento cuja frequência mais aumentou, sendo que as inundações bruscas tiveram $72 \%$ e as inundações graduais 80\% de aumento (CONORATH, 2012). Sausen e Narvaes (2013) destacam que o estado de Santa Catarina aparece quatro vezes na lista dos maiores desastres naturais do Brasil, em 1911, 1974, 1983 e 2008, esses eventos totalizaram um número de 30 mil mortos, entre inundações e deslizamentos.

O município de Joinville, situado na região norte do estado de Santa Catarina, possui aproximadamente 554 mil habitantes, sendo a maior cidade do estado em população, com uma densidade demográfica de 453 hab./ km². É o mais importante polo econômico, tecnológico e industrial do estado (JOINVILLE CIDADE EM DADOS, 
2014). Desde sua fundação em 1850 com a chegada dos imigrantes alemães, o município se desenvolveu numa região adversa, do ponto de vista urbanístico (SILVEIRA et al., 2009). Em uma região que apresenta clima tropical e subtroprical superúmido, com umidade relativa do ar atingindo uma média acima de 78\%, temperatura média anual de 22 graus centígrados, média pluviométrica mensal de 190,08 mm (SILVEIRA et al., 2009). Além de todos esses fatos já mencionados, durante os períodos de amplitude da maré verifica-se a inversão do fluxo da água do rio Cachoeira, principal bacia urbana da cidade (BHRC), até quase a metade de seu percurso, causada pelo ingresso de água salgada vinda através do canal da baía da Babitonga. Essa ocorrência pode causar inundações mesmo em dias sem chuvas, principalmente no centro da cidade, pois parte das margens do rio Cachoeira está apenas dois metros acima do nível do mar. Tais características fazem com que a cada três ou quatro anos (no período da lua cheia ou lua nova) ocorra no mínimo uma forte cheia, fazendo com que a cidade fique inundada tanto com a cheia do rio quanto pelo nível das marés (SILVEIRA et al., 2009).

Em 157 anos de história, 111 inundações atingiram a população de Joinville. Nesse sentido, Silveira et al. (2009) apontam que a bacia do rio Cachoeira foi a região em que se registrou a maior frequência das inundações (30\%).

De acordo com Muller et al. (2013b), a BHRC localiza-se na região urbana de Joinville tendo sua foz na baía da Babitonga, representando 7,3\% de área da região onde vive $49 \%$ da população. Eventos meteorológicos associados às marés astronômicas (marés altas) geram grandes inundações a cada dez anos, com uma média de 2,53 metros, podendo inundar $10,73 \mathrm{~km}^{2}$ da área urbanizada. Nesses eventos, o centro da cidade que correspondendo à BHRC tem 29,4 \% de sua área tomada pela inundação (JOINVILLE, 2011a). Muller 
(2012), em seus estudos, aponta que a BHRC tem 56\% de sua área situada em uma região suscetível a inundações categorizadas como altas e muito altas. $O$ alto índice de suscetibilidade a inundações dessa região, acrescenta Muller (2012, p. 84), relaciona-se diretamente com a geomorfologia da região,

[...] cujas feições geomorfológicas apresentam alta suscetibilidade a inundações (planície de maré, terraço fluvial, terraço lagunar e planície colúvio aluvionar, configurando as feições encontradas no fundo dos vales), associadas à altas taxas de impermeabilização do solo (áreas urbanizadas) e baixas declividades (<12\%).

Observando tais fatos, a Defesa Civil de Joinville, juntamente com outros órgãos municipais, estabeleceu uma Rota Segura para Dias de Inundações (RSDI) com mapa (Figura 1), com o intuito de possibilitar um trajeto livre de inundações para a população e visitantes. Essa ação visa auxiliar e orientar a população, prevenindo e reduzindo os riscos nos momentos das ocorrências de fenômenos adversos que atingem a região todos os anos.

Figura 1 - Recorte do mapa Rota Segura demonstrando a área central de Joinville e BHRC

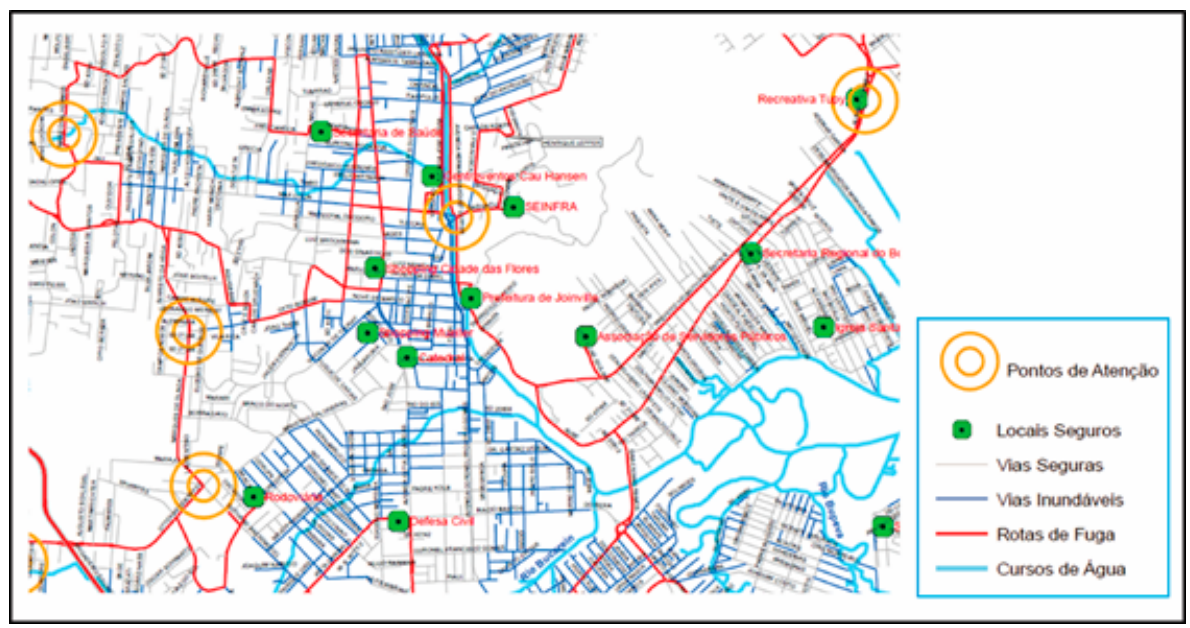

Fonte: Defesa Civil (2013) 
Entre as cidades brasileiras, a RSDI do município de Joinville é inovadora, sendo a única no país que apresenta uma rota tanto para área urbana quanto para a área rural. A rota, porém, não possui sinalizações ou elementos visuais que identifiquem o trajeto da rota, nem tampouco que orientem ou indiquem como chegar até ela, sendo esse o grande motivador para a definição de Joinville como foco dos estudos.

A partir do cenário apresentado, o desenvolvimento de uma proposta de Sistema de Informação por meio de elementos visuais se mostrou necessário como parte integrante do projeto da RSDI. A orientação feita por meio de elementos visuais torna o percurso mais claro e objetivo, fazendo com que os envolvidos se encontrem e se desloquem mais rapidamente nos momentos de risco de inundações, facilitando a orientação sem a necessidade de utilização de um mapa.

Nesse sentindo, conceitos atrelados à Wayfinding, sinalética, design (informação e sinalização) e sinalização (normas e leis) foram pesquisados. Segundo Scherer e Uriartt (2012), o termo Wayfinding surgiu em 1960 com Kevin Lynch e mais tarde foi retomado por Paul Arthur e Romedi Passini. Segundo os autores, o termo representa a relação dinâmica de uma pessoa com o espaço, constituindo-se como uma nova abordagem para estudar o processo de alcançar ou chegar a um destino, em um ambiente familiar ou não (ARTHUR; PASSINI, 2002). Baumann (2013) destaca que, além disso, ele é importante por mostrar informações em pontos estratégicos e também por guiar as pessoas na direção correta. Segundo Scariot (2013), com intuito de auxiliar o deslocamento em ambientes físicos e na construção dos mapas cognitivos, designers e outros profissionais constroem e organizam os espaços, introduzindo sistemas de SIW próprios para cada ambiente. 
Artefatos como mapas, placas, totens, sinais, luzes entre outros, podem ser utilizados para facilitar o processo de orientação do indivíduo. Tais artefatos, contudo, serão eficazes somente se o indivíduo conseguir interpretar as informações e relacioná-las com o ambiente em questão. $\mathrm{O}$ Wayfinding deve ser um meio eficiente no momento de englobar as informações, incluindo textos, pictogramas, mapas, fotografias, esquemas e diagramas, e os indivíduos devem observar, ler, aprender e compreender esses elementos para que possam concretizar sua movimentação (SCARIOT, 2013). Nesse sentindo, Caldeira (2013, p. 3) aponta que o Design de Sinalização (DS) tem como vocação criar informações para os indivíduos em meios urbanos ou arquitetônicos, entrando no grupo do chamado Design Gráfico Ambiental (DGA). Há de se observar que ele não está ligado somente a uma única área de conhecimento, pois envolve "[...] a intersecção entre design gráfico, design de produto, arquitetura, urbanismo e comunicação, com o intuito de informar, orientar, identificar e ambientar".

Dentro do espaço público (aberto) a redução da informação é essencial. Nesse contexto, o domínio de formas de linguagem básica prevalece e se mostra um meio a ser estudado para o momento de projetar sinais ou sistemas de sinalização para tais ambientes.

Sendo assim, Costa (2011a) aponta que a sinalética deve ser empregada, sendo ela uma das facetas do design de informação, e se trata de uma informação instantânea, inequívoca, utilitária, pois assim encontramos um determinado sinal que nos guia. A sinalética nos espaços públicos e os sistemas de sinalização urbana e viária coexistem, mas não são equivalentes. Os objetivos de um e de outro sistema são diferentes. A sinalética é um sistema criado para servir aos indivíduos, adaptando-se a cada ambiente ou problema específicosem exercer a força de leis e normativas, ela apresenta uma opção, 
com códigos de leitura parcialmente conhecidos, reforçando ou criando uma identidade para o ambiente. Já a sinalização objetiva regulamentar o fluxo de pessoas e veículos por meio de um sistema normativo e restrito, uniformizando todo o ambiente em que está inserida como, por exemplo, a sinalização viária (no Brasil estabelecida pelo Código de Trânsito Brasileiro - CTB) e de segurança (no Brasil estabelecida pela Norma Brasileira-NBR 13.434-2) (CALDEIRA, 2013).

Hunter (2013) reforça a ideia de que nos espaços públicos a sinalização deve ser organizada para transmitir informações aos indivíduos, considerando suas capacidades e permitindo que se locomovam e se localizem com facilidade. Dessa forma a sinalização se torna um processo de veiculação de informações com o objetivo de transmiti-las, por meio de sinais ou elementos visuais (linguísticos, cromáticos e icônicos), orientando e guiando os indivíduos nos diferentes espaços construídos (CARDOSO et al., 2014c).

Para que tal processo seja bem-sucedido no ambiente urbano, mostrando-se realmente eficiente dentro do que se pretende com ele, normativas e experiências de outras áreas do conhecimento (científico-técnico) devem ser consultadas. Sendo assim a partir de estudos teóricos, reuniões com diferentes órgãos públicos de Joinville foram realizadas.

\section{DESIGN}

A etapa de design teve início com a realização de reuniões com a Defesa Civil de Joinville e, posteriormente, com o IPPUJ e DETRANS para a apresentação do projeto e obtenção de informações e opiniões sobre o tema em estudo. Como resultado de tais encontros, foram estabelecidos objetivos para o projeto. A partir desses objetivos traçou-se um esboço do projeto, o qual foi apresentado no X Fórum 
Nacional da Defesa Civil do ano de 2013. Dessa forma, foi possível, a partir da conversa informal sobre o assunto, obter sugestões de diferentes agentes e técnicos dos diversos serviços de Defesa Civil Nacional. Além disso, foi possível identificar com eles a falta de projetos de sinalização com características voltadas aos processos de inundações no território brasileiro.

\section{DESIGN - DESIGN ESQUEMÁTICO}

Para o início dessa etapa foram analisados diferentes mapas utilizando Sistemas de Informação Geográfica e mapas gerados no município de Joinville, como parte do Sistema Municipal de Informações Georreferenciadas (SIMGeo), os quais foram disponibilizados por diferentes órgãos públicos do município de Joinville/SC (Defesa Civil, IPPUJ, Ministério da Fazenda, entre outros). Para a visualização da área da BHRC foram realizadas sobreposições dos mapas com as diferentes informações de interesse, o que possibilitou uma delimitação (recorte) mais específica dentro dessa área. Os mapas (ou camadas) utilizados para visualização da área a ser estudada foram o Rota Segura para Dias de Inundações, Limite de Bairros, Vias Urbanas e o da mapa da Mancha de Inundações da Bacia Hidrográfica do Rio Cachoeira (sub-bacia do rio Mathias) com tempo de reincidência de cinco anos. Com a sobreposição das camadas de informações, dos mapas e dos conhecimentos técnicos e de campo da Defesa Civil de Joinville foi possível delimitar uma área na BHRC (sub-bacia do rio Mathias), onde a incidência de inundações é frequente, sendo observado que esta possui um o alto índice de ruas no centro da cidade (aproximadamente 50 ruas), que situam-se em locais de risco, tendo cerca de $29,4 \%$ de sua área afetada pelas inundações (JOINVILLE, 2011a). 
Assim, foram identificados e definidos não apenas os pontos a serem sinalizados, mas também quais sinalizações deveriam ser utilizadas para cada situação. O processo de Wayfinding proposto por Gibson (2009), que consiste nas etapas de Informações Regulatórias, Informações de Orientação, Informações Direcionais e Informações de Indicação, foi aplicado na definição dos pontos a serem sinalizados, bem como para identificar quais sinalizações deveriam ser utilizadas em cada situação, pois o processo se aproxima da nomenclatura da CTB (2008), o que facilita a identificação desses pontos e das características específicas de cada um, sendo também um meio para definir as estruturas físicas de cada sinalização (totens, placas, artefatos luminosos, entre outros). Todas as definições dos pontos a serem sinalizados foram apresentadas, revistas e adequadas com a Defesa Civil de Joinville, DETRANS e IPPUJ. Recorda-se que todas as sinalizações, mesmo aquelas que não são comuns ao CTB (2008), devem manter suas regras básicas de posicionamento e diagramação, garantindo assim a sua eficácia e regularização.

A partir de então foram criados os elementos visuais para compor tais espaços, os quais deverão ser conectados ao sistema pluviométrico online da Defesa Civil de Joinville, que detecta em tempo real o aumento do nível das águas e que será o responsável por acionar os elementos automaticamente, tornando o sistema dinâmico e imediato no que se refere ao fornecimento de informação.

\section{DESIGN - DESENVOLVIMENTO DE DESIGN}

Após análises e definições sobre a área de estudo e os principais conceitos que o tema aborda, teve início o processo criativo para o desenvolvimento da sinalização para a RSDI. Primeiramente foram criados sinais visuais (pictogramas) que representassem os locais 
com risco de inundação na BHRC com base nas regras do CTB (2008) e alguns exemplos de placas. Posteriormente foi criado um logotipo para RSDI (Figura 2), sendo que o nome Rota Segura para Dias de Inundações foi alterado para Rota Segura de Inundações (RSI), tornando a leitura da informação mais rápida e simples (com base em conceitos de sinalética) para a população e facilitando também a sua aplicação em placas e sinalizações

Figura 2 - Logotipo para RSDI

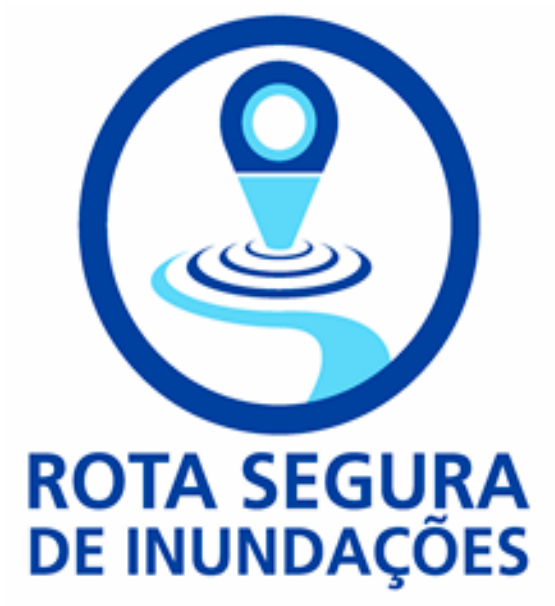

Fonte: elaborada pelos autores (2014)

Com a definição do logotipo para a Rota Segura de Inundações (RSI) aprovada pela Defesa Civil, foram criados os elementos visuais (totens) com características inspiradas no próprio logotipo. Estabeleceu-se, assim, um padrão visual que facilita a compreensão por parte dos usuários auxiliando de forma mais efetiva em sua locomoção com segurança durante as ocorrências de inundações. Além disso, os elementos estarão conectados ao sistema online de detecção automática (tempo real) do aumento dos níveis das águas da Defesa Civil (já em funcionamento), tornando-os mais dinâmicos e imediatos para informação. 
Os elementos visuais foram divididos em totens regulatórios de orientação iluminados e não iluminados, orientação para níveis de inundação iluminados, direcionais iluminados compostos por placas e compostos por setas, bem como sinalizações de indicação e sinalização auxiliar. Para a alimentação energética dos elementos, poderão ser utilizados, futuramente, sistemas de painéis solares com baterias, implantados na base de cada elemento ou em instalações próximas. Esses requisitos técnicos não serão aprofundados, uma vez que se trata de outra área do conhecimento e, para que tais explicações fossem efetivas, seria necessário enredar em um processo que fugiria do foco principal desta pesquisa.

Para todos os elementos criados, foram aplicados os contextos teóricos e técnicos estudados na fundamentação teórica, bem como as regras do CTB (2008) e de seus manuais estabelecidos pelo CONTRAN em 2007. Na Figura 3 será apresentado o exemplo de um dos elementos visuais (totens de orientação para níveis de inundação iluminados) criados e as explicações relacionadas às funções, materiais e composição. É importante salientar que os elementos foram baseados também em relação a sua altura com base na altura dos brasileiros (homens e mulheres), segundo última pesquisa de Orçamentos Familiares de 2002-2003 realizada pelo IBGE (IBGE, 2014).

Os totens de orientação para níveis de inundação iluminados (Figura 3) têm a função de informar e advertir sobre os níveis de inundação que atingem cada área, os materiais empregados em sua estrutura deverão ser o plástico ou acrílico, e seu formato em triedro (três vistas - facilitando a visualização de diferentes ângulos). As suas cores seguiram as normas do CTB (2008), bem como a NBR 13.434-2 para sinalizações de emergência. 
A área para o posicionamento desses totens foi definido com a Defesa Civil, IPPUJ e DETRANS:

- Totem de nível 1 (iluminação na cor azul): sinaliza as áreas livres de inundações, bem como o percurso da RSI;

- Totem de nível 2 (iluminação na cor laranja): sinaliza as áreas que merecem atenção, pois podem ser afetadas pelas inundações;

- Totem de nível 3 (iluminação na cor vermelha): sinaliza as áreas com alto risco de inundação.

Figura 3 - Totens de orientação para níveis de inundação - iluminados - 2D e 3D
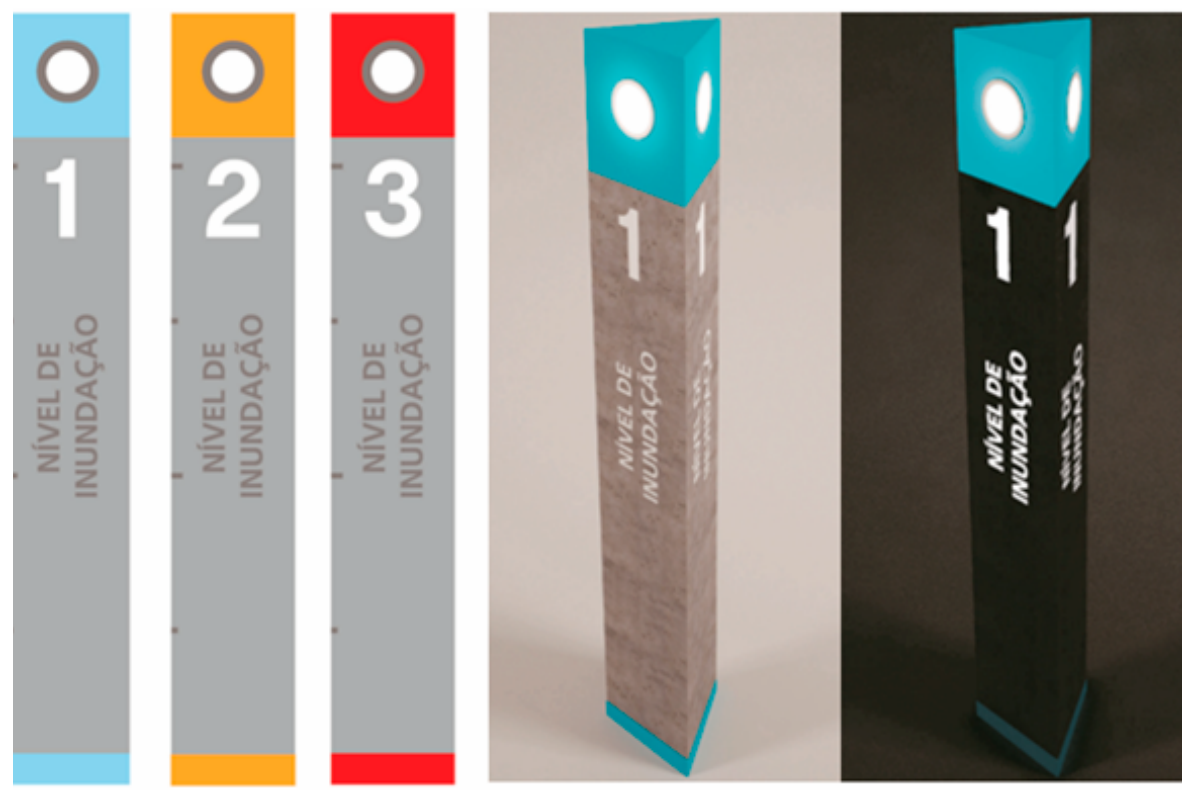

Fonte: elaborada pelos autores (2015)

Esses totens são compostos por três partes: 1) Base - será toda em plástico, com a função de sustentar o totem e comportar também em sua parte superior (no interior do totem, longe do alcance da água e vandalismos) os sistemas de energia e conexão wi-fi com o sistema pluviométrico online da Defesa Civil. Deve possuir também 
demarcações (traços) em seus cantos de meio em meio metro, indicando o nível da inundação. obs: Esse sistema de demarcação de nível de inundação foi solicitado pela Defesa Civil, pois esta compreende que tal medida é a mais coerente para a visualização dos usuários no momento da inundação. 2) Iluminação - na parte superior do totem se encontram os elementos luminosos em acrílico coloridos (translúcidos), com seus círculos transparentes para facilitar a saída da luminosidade. No interior desse elemento fica o sistema de iluminação por lâmpada fixa (estática). Este possui iluminação estática para não entrar em conflito com a informação luminosa dos totens de regulamentação que possuem um sistema de iluminação por giroflex. O elemento luminoso deverá ser encaixado no totem, facilitando sua remoção para manutenções, limpezas ou reposições. 3) Informações dos níveis de inundação - na parte superior do totem, abaixo da iluminação, ficam as numerações dos níveis de inundações. Tanto os números quanto os textos são retrorrefletivos a luz, sendo iluminados pela própria luz do totem.

Os totens de orientação para níveis de inundação iluminados deverão ser implantados próximos ao final das quadras das ruas, obedecendo aos posicionamentos e suas relações de distanciamento perante a via, estabelecidos pelo CTB (2008). Dessa forma, os usuários poderão visualizar a certa distância se estão fora ou dentro de uma área de risco, como também identificar, pela coloração luminosa dos totens, se estão se locomovendo de encontro ou saindo da área de risco.

\section{CONSIDERAÇÕES}

Os elementos visuais desenvolvidos para RSI, bem como para os momentos de inundações na BHRC (recorte), além de possibilitarem 
uma locomoção mais segura por parte dos envolvidos, estabelecem uma vivência com eles nos dias sem inundações, em virtude de suas configurações visuais e funções. Dessa forma, auxiliam também na visualização de locais seguros e com riscos de inundações antecipadamente, bem como nos momentos de inundações, alertando, orientando e indicando os caminhos a serem seguidos por meio de seus elementos luminosos. Pode-se apontar que uma das características mais marcantes do presente estudo está ligada à sua interdisciplinaridade, estabelecida com o DETRANS, IPPUJ e Defesa Civil de Joinville, que contribuíram para uma visualização voltada ao problema e objetivos do presente estudo, possibilitando também o conhecimento da complexidade que envolve a gestão do ambiente urbano, com ou sem a presença de inundações.

A vivência deste estudo possibilitou entender melhor como as inundações se comportam na área central do munícipio de Joinville, bem como conhecer como o DETRANS, IPPUJ e Defesa Civil de Joinville tratam esse processo no campo teórico e na prática. A partir desses conhecimentos e dos estudos teóricos realizados, foi possível contemplar todos os objetivos determinados para este trabalho.

Durante o processo da pesquisa foram encontradas duas dificuldades em específico. A primeira está relacionada à falta de pesquisas sobre sinalizações ou sobre como aplicá-las no ambiente urbano em momentos de inundações. A segunda se refere à complexidade em se desenvolver estudos como este, uma vez que são necessários os saberes técnicos e específicos de diferentes áreas do conhecimento, o que gera dificuldades ao pesquisador para contextualizar e processar todos os assuntos.

A falta de pesquisas na área de sinalização para momentos de inundações no ambiente urbano possibilita diferentes estudos futuros para área do design, bem como para as demais áreas do 
conhecimento. Nesse sentido, ressalta-se que a relação entre os conhecimentos configura-se como um ponto nevrálgico para a construção de tais processos de estudo e pesquisas.

A relevância social de projetos cujo foco é orientar e auxiliar as pessoas em momentos de risco de inundações se mostra evidente em virtude do crescimento dos centros urbanos e do consequente aumento na incidência dos desastres ambientais relacionados às inundações. Além disso, torna-se essencial suprir a falta de estudos nessa área quanto a planos urbanos focados em sinalizações para esse fim.

Sabe-se que muito ainda deve ser pesquisado em relação aos sistemas de sinalização para momentos de emergência com inundações em ambientes urbanos, principalmente pela inexistência de projetos nessa área em âmbito mundial. Nesse sentindo, o presente estudo também aponta a importância da evolução de tais estudos em diferentes áreas do conhecimento, além de ser um passo importante para o início de tais processos.

Espera-se que os elementos visuais desenvolvidos possam ser construídos, testados e analisados in loco, possibilitando assim, alterações e adequações, tornando-os mais eficazes dentro das funções que Ihes foram estabelecidas nesta pesquisa. 


\section{REFERÊNCIAS}

ARTHUR, P.; PASSINI, R. Wayfinding: people,signs and architecture. Ontario-Canadá, Focus Strategic Communications Incorporates, 2002.

BARBOSA, D. R. et al. Risco ambiental de enchentes nos rios formadores da f acia do rio Piabanha (região serrana Fluminense). Universidade Gama Filho, Pró-Reitoria de Humanidades e Ciências Sociais, Curso de Geografia. Rio de Janeiro, 2013.

BAUMANN, S. Intoduction to wayfinding and signage design. nov. 2010. Disponível em: <htttp://www.designworkplan.com/ wayfinding/introduction.htm>. Acesso em: 1 fev. 2013.

CALDEIRA, R. Comunicação e Práticas Semióticas nos Não lugares. Lisboa: Universidade de Lisboa. Faculdade de Letras de Lisboa, 2013.

CALORI, C. Signage and Wayfinding Design: a complete Guide to creating environmental graphic sesign systems. Nova lorque: Wiley John \& Sons, 2007.

CARDOSO, E. et al. Composição visual da vetas. Disponível em: <http://ndga.wordpress.com/2012/04/03/infograficos-sinalizacaoambientacao-2/> abril, 2012>.Acesso em: 06 jun. 2014.

CONORATH, G. D. Águas urbanas: análise morfométrica e hidrológica da bacia hidrográfica do rio Cachoeira - Joinville/SC. 2012 [incluir número de folhas]. Dissertação (Mestrado em [completar]) - MPPT/ FAED/UDESC, Florianópolis, 2012.

COSTA, J. Design para os olhos: marca, cor, identidade e sinalética. Tradução de Fernanda Soares. Lisboa: Dinalivro, 2011. 
CTB-CÓDIGO DE TRÂNSITO BRASILEIRO. Código de Trânsito Brasileiro: instituído pela Lei 9.503, de 23/09/97. 3. ed. Brasília: DENATRAN, 2008.

CONTRAN. Manual Brasileiro de Sinalização de Trânsito. V. I: Sinalização Vertical de Regulamentação. Brasília, 2007a.

- Manual Brasileiro de Sinalização de Trânsito. V. II: Sinalização Vertical de Advertência. Brasília, 2007b.

- Manual Brasileiro de Sinalização de Trânsito. V. III: Sinalização Vertical de Indicação. Brasília, 2007c.

- Manual Brasileiro de Sinalização de Trânsito. V. IV: Sinalização Horizontal. Brasília, 2007d.

Manual Brasileiro de Sinalização de Trânsito. V. V: Sinalização Semafórica. Brasília, 2007 .

- Manual Brasileiro de Sinalização de Trânsito. V. VI: Sinalização de Obras e Dispositivos Auxiliares. Brasília, $2007 f$.

GIBSON, D. The Wayfinding Handbook: information design for public places. Nova lorque: Princeton Architectural, 2009.

IBGE. Primeiros resultados: Brasil e grandes regiões. Disponível em:<http://www.ibge.gov.br/home/estatistica/populacao/ condicaodevida/pof/2002/>. Acesso em: 10 abr. 2014.

JOINVILLE CIDADE EM DADOS. Disponível em:

<https://ippuj.joinville.sc.gov.br/arquivo/lista/codigo/442-Joinville \%2BCidade\%2Bem\%2BDados\%2B2014.html>. Acesso em: 10 abr. 2014. 
JOINVILLE. Drenagem Urbana: Joinville enfrenta o desafio. Plano Diretor de Drenagem Urbana da Bacia Hidrográfica do Rio Cachoeira-PPDU. Joinville, 2011a.

MULLER, C. R. Avaliação de Suscetibilidade a Inundações utilizando Geotecnologias para a Bacia Hidrográfica do Rio Cachoeira - Joinville/SC. Universidade do Estado de Santa Catarina, Florianópolis, mai. 2012.

MULLER, C. R. et al. Ocupação em Joinville/SC e o Papel da Gestão Municipal para Mitigação de Dano Causados por Inundações. Revista Brasileira de Planejamento e Desenvolvimento, Santa Catarina, v. 1, n. 1, jul./dez. 2012a.

MULLER, C. R. et al. Bacias hidrográficas urbanas e a problemática das inundações-Estudo de caso: bacia hidrográfica do Rio Cachoeira - Joinville/SC. In: SIMPÓSITO BRASILEIRO DE SENSORIAMENTO REMOTO - SBSR, XVI, Foz do Iguaçu. Anais... Foz do Iguaçu, PR, Brasil: INPE, 13 a 18 abr. 2013b.

PEZZIN, O. C. Design de sinalização do Metrô de São Paulo: estudo de caso de sua manutenção. Faculdade de Arquitetura e Urbanismo, Universidade de São Paulo, São Paulo, 2013.

PIZZA. S. E. Brasil assimilou a importância do seguro contra riscos e inundações. Disponível em: <http://www.swissre.com/ latin_america/brasil_assimilou_importancia_seguro_contra_riscos_ inundacoes.html>. Acesso em: 24 nov. 2013.

SAUSEN, T. M.; NARVAES, I. S. Desastres naturais e geotecnologias: Inundações. Santa Maria, RS: INPE/CRS, 2013.

SILVEIRA, W. N. et al. História das inundações em Joinville: 18512008 - Curitiba: Organic Trading, 2009. 
SOUZA, E. Em 20 anos zonas urbanas do país crescem o equivalente a duas Xangai. Disponível em: <http://noticias.uol. com.br/cotidiano/ultimas-noticias/2011/04/29/em-20-anos-zonasurbanas-do-pais-crescem-o-equivalente-a-duas-xangai.htm $>$. Acesso em: 10 jun. 2013.

SCARIOT, C. A. Avaliação de sistemas de informação para wayfinding: um estudo comparativo entre academia e mercado em Curitiba, 2013. 179 f. Dissertação (Mestrado em Design) - Setor de Ciências Humanas, Letras e Artes da Universidade Federal do Paraná, 2013.

SCHERER, F.V.URIARTT, S. M.P.O uso da cor em sistemas de sinalização. In: CONGRESSO INTERNACIONAL DE ERGONOMIA E USABILIDADE DE INTERFACES HUMANO-TECNOLOGIA, 12., ago. 2012, Natal. Produto, informações e ambiente construído e transporte. Natal, RN, Brasil: [quem publicou], 2012.

UN/ISDR. International strategy for disaster reduction. Terminology on Disaster Risk Reduction. Disponível em: <http:// www.unisdr.org/>. Acesso em: 9 out. 2013. 



\title{
Design de superfície: a valorização do Museu Nacional do Mar por meio da criação de artefatos
}

\author{
Irma Haensch Pereira (Currículo Lattes) \\ João Eduardo Chagas Sobral (Currículo Lattes)
}

\section{INTRODUÇÃO}

Em um território com mais de 8,5 milhões de quilômetros quadrados, o Brasil é um país de riquezas ímpares e das mais diversificadas. O seu tamanho e a sua trajetória histórica proporcionam variados contextos culturais, que se distinguem ora por sua localização geográfica, ora pela linha do tempo de seus acontecimentos.

A cidade litorânea de São Francisco do Sul, localizada ao norte de Santa Catarina, é detentora de algumas dessas riquezas que o país apresenta. Possuindo mais de 500 anos de história, a cidade é dotada de um vasto acervo cultural e histórico, como o Museu Nacional do 
Mar. Esse conteúdo histórico-cultural instigou a fazer uso do museu e de suas peculiaridades como tema de inspiração de projeto.

$O$ referencial que surge de um tema, mais precisamente local, nem sempre é explorado de modo a ultrapassar fronteiras. Muitas vezes a globalização unifica, podendo também descaracterizar os locais e suas particularidades. Paulo Freire relata em seu texto que:

\begin{abstract}
Antes de tornar-me um cidadão do mundo, fui e sou um cidadão do Recife, a que cheguei a partir de meu quintal, no bairro de Casa Amarela. Quanto mais enraizado na minha localidade, tanto mais possibilidades tenho de me espraiar, me mundializar. Ninguém se torna local a partir do universal. O caminho existencial é inverso. Eu não sou antes brasileiro para depois ser recifense. Sou primeiro recifense, pernambucano, nordestino. Depois, brasileiro, latinoamericano, gente do mundo (FREIRE, 2001, p. 25).
\end{abstract}

Ao expor embarcações, costumes e tradições náuticas brasileiras, o Museu Nacional do Mar apresenta a história cotidiana dos homens trabalhadores do mar e reforça a importância da sua significação cultural para a sociedade. Ao reconhecer a singularidade presente no museu, este se torna parte do todo, ou seja, global. Logo, como problema de pesquisa para esse projeto, surge a pergunta: como utilizar o design de superfície para contribuir com a valorização do Museu Nacional do Mar por meio da criação de artefatos que o represente?

A intenção deste projeto foi buscar referências no Museu Nacional do Mar a fim de criar artefatos a serem comercializados e admirados de maneira que não fossem restritos à região, mas também além das fronteiras. Buscou-se contribuir culturalmente para o museu e promovê-lo por meio dos subsídios que este local oferece, mais precisamente nas peculiaridades simbólicas de seu acervo, de modo a torná-las universais. Para que a valorização do museu fosse alcançada, o design de superfície foi a atividade criativa utilizada 
para reforçar a identidade do local e o design thinking, a ferramenta de inovação escolhida.

Este projeto se relacionou com a linha de pesquisa de produção do designe contexto sociocultural do mestrado profissional em Design a partir do objeto de estudo, Museu Nacional do Mar. A possibilidade de se trabalhar com o museu e com o Design de Superfície retoma estudos já realizados pelos autores anteriormente. O Museu Nacional do Mar foi o tema no trabalho de conclusão de curso da graduação e nas investigações sobre uma das áreas de Design de Superfície, a estamparia, a qual foi seu foco de estudo e área de trabalho desde sua participação na especialização da Universidade Federal de Santa Maria [UFSM], Rio Grande do Sul, em 2006.

A sociedade em constante transformação, aliada ao conteúdo histórico do museu, articulou uma oportunidade de se aprofundar no processo de investigação para inovação, unindo ao Design de Superfície o reduto cultural que o museu representa. O acervo não apenas agregou com sua riqueza de informações ao projeto sua singularidade - como também contribuiu na sua valorização e preservação diante do registro que foi realizado, tornando-se universal. Tal reapresentação de seus aspectos combinados ao Design de Superfície careceu de um ou mais suportes nos quais suas superfícies fossem elaboradas. Esses suportes foram apresentados no decorrer do desenvolvimento do projeto, uma vez que foi parte da pesquisa desvendá-los. A intenção foi que esses artefatos, independentemente do seu processo produtivo, fossem portadores da identidade cultural do Museu Nacional do Mar.

A partir do estudo das diferentes possibilidades de artefatos que representassem a intenção do projeto por meio da aplicação do Design de Superfície, foram investigados modos de produzi-los da melhor maneira possível. O estudo considerou o que o mercado já 
oferece no segmento de produtos destinados à indústria do turismo. Houve, neste projeto, a possibilidade de investigar as relações e ações do design a partir da ressignificação cultural dentro do cenário de um local como o Museu Nacional do Mar. Contemplou-se, dessa forma, a ênfase do projeto no contexto sociocultural, bem como tecnológico.

Para o desenvolvimento do projeto e a elaboração dos designs de superfície, estudou-se quatro temas: a cidade de São Francisco do Sul e o Museu Nacional do Mar; a identidade da cultura local; o design de superfície; e o design thinking. A exploração desses temas estruturou este projeto de maneira a apresentar seus assuntos e sequenciar todo o seu conteúdo.

Em um primeiro momento, o contexto do projeto foi estudado. Conhecer São Francisco do Sul e suas características históricas, culturais e geográficas tornou-se determinante, uma vez que foi o ponto de partida neste projeto para depois apresentar o Museu Nacional do Mar. Questões pertinentes à história, ao acervo, ao espaço físico e ao perfil turístico do museu auxiliaram na compreensão de suas características.

Na primeira parte da fundamentação teórica, estudou-se a identidade da cultura local e o modo como se articula. Enquanto design e território, a identidade cultural mostrou-se ponto fundamental na sua compreensão e conhecimento, tendo como base autores como Edgar e Sedgwick (2003), Geertz (1978), Engels et al. (1980) e Borges (2011). Na sequência, o design de superfície teve sua relevância ao ser observado como uma área que se utiliza de "recursos da linguagem visual como meio de expressão", segundo Rüthschilling (2013, p. 61). Ao trabalhar com diferentes materiais e superfícies, o papel, a cerâmica e os têxteis se destacam na aplicação do design de superfície, porém a possibilidade de aplicação não se restringe a eles, oportunizando que outros materiais sirvam de 
suporte aos desenhos. Por último, o design thinking se apresentou como ferramenta de inovação para o desenvolvimento do projeto. Ele atuou na estruturação do projeto em si, como também auxiliou na escolha dos artefatos a serem apresentados ao fim deste projeto.

Fundamentado em quatro temas - Museu Nacional do Mar, identidade cultural, design de superfície e design thinking-a metodologia deste projeto foi estruturada em três fases distintas. A primeira correspondeu à organização da problemática e da definição dos objetivos. A segunda fase referiu-se à realização simultânea de diferentes pesquisas - bibliográfica, imagética e de artefatos. A terceira fase foi dedicada ao projeto das superfícies aplicadas aos artefatos.

A metodologia foi baseada em Marconi e Lakatos (2003), Gil (2008) e Gerhardt e Silveira (2009). O projeto se caracterizou como uma pesquisa qualitativa de caráter exploratório que, para sua realização, se utilizou das pesquisas bibliográfica, imagética e de produtos, bem como se apresentou como uma pesquisa participante.

A junção dos diferentes tipos de pesquisa ocorreu tanto por causa do objeto de estudo que direciona o projeto, como pelos artefatos que foram escolhidos como suportes para aplicação do design de superfície. Esses diferentes modos de investigação foram unidos à pesquisa participante, uma vez que a pesquisadores fez parte do método de análise científica, envolvendo-se e identificandose, também, com o objeto de estudo.

Ao discorrer sobre identidade cultural, design de superfície e design thinking, o desenvolvimento do projeto recebeu um alicerce no qual os seus conteúdos foram expostos e deram suporte para a elaboração dos resultados que foram obtidos. Acredita-se que associar simbologias e emoções que representem o acervo cultural do Museu Nacional do Mar por meio do design de superfície foi o 
desafio no desenvolvimento de artefatos. Sendo o museu um local em que se concentram riquezas culturais, reforçar tal concentração e atrair novos olhares foi a intenção do projeto de Design de Superfície: a valorização do Museu Nacional do Mar por meio da criação de artefatos.

\section{PROJETO}

O processo de criação deste projeto se deu pela busca de referência na identidade cultural pertencente ao Museu Nacional do Mar (Figura 1). O design pode ser analisado tanto como uma atividade projetual a ser utilizada no desenvolvimento de artefatos que expressam tal identidade cultural, como também na busca por métodos que alcançam a inovação desejada. Ao se apresentar como elemento de grande valia para a inovação, o design impulsiona e gera valor que é percebido pelas pessoas, podendo atuar em produto, processo ou serviço.

Figura 1 - Embarcações do Museu Nacional do Mar

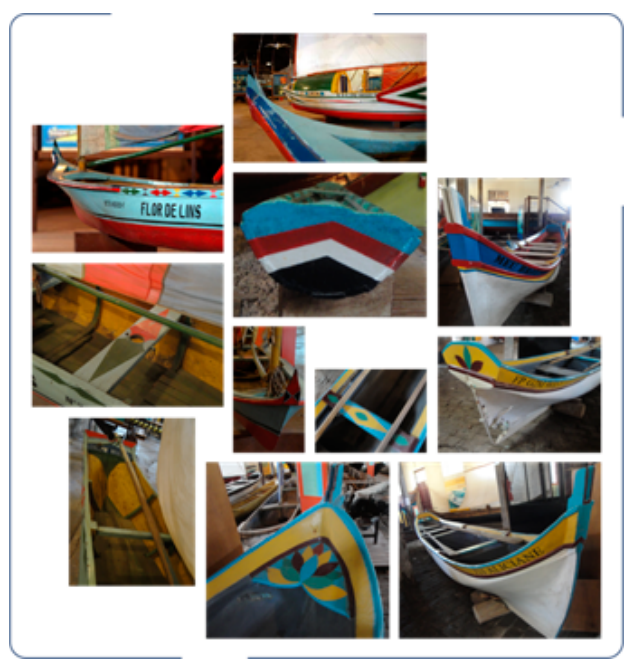

Fonte: primária e Tempo Editoral (empresa) 
A fim de agregar qualidade ao resultado do projeto, o "pensar design" foi a metodologia que tinha os princípios favoráveis ao seu desenvolvimento, pois para o sucesso de sua implantação necessitava-se alcançar os princípios do design thinking. São estes: ser tecnicamente viável de ser produzido, financeiramente possível de ser realizado e que resultasse em artefatos desejáveis pelas pessoas que frequentam o museu. Quando essas três características estão presentes, é tido como o ideal para um projeto.

Para que se obtivesse tal resultado pela aplicação do design thinking em um projeto, foi preciso observar que ele possuía etapas a serem cumpridas em seu processo. Vianna et al. (2012) apresentam as etapas como sendo a fase de imersão, de análise e síntese, de ideação e de prototipação.

Enquanto parte do projeto direcionado a elaborar artefatos para o Museu Nacional do Mar, entendeu-se que a fase de imersão, pela qual se compreende o problema levantado no projeto, foi aquela em que se aproximou do contexto do problema e que os assuntos relevantes a ele foram pesquisados. As pesquisas bibliográfica e simbólica pertenceram a essa fase. A Figura 2 mostra essa etapa sinalizada pelo fundo amarelo da imagem, que ocorreu em paralelo com a fase de análise e síntese, uma vez que o processo de avanço da pesquisa não necessitava ser linear e permitia que o benchmarketing e a pesquisa de campo fossem feitos simultaneamente. 
Figura 2 - Etapas do processo de design thinking aplicadas no projeto

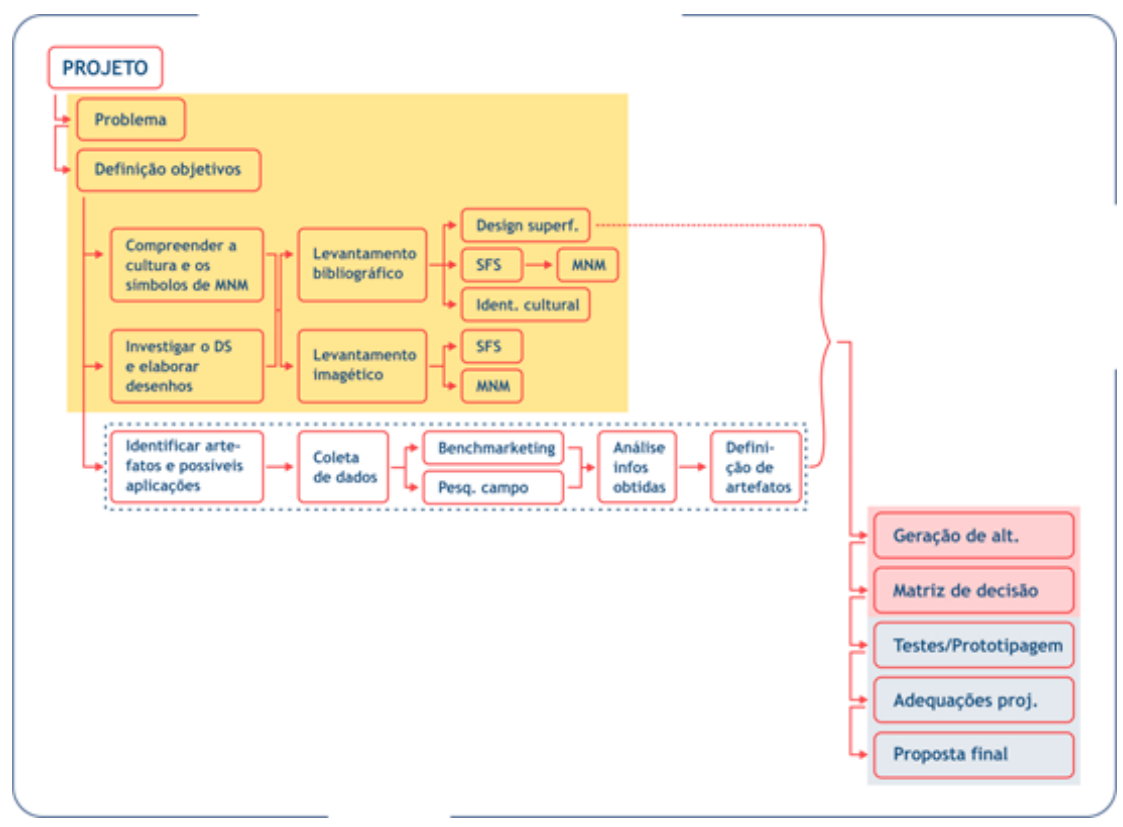

Fonte: primária (2015)

A fase de análise e síntese, também chamada de fase de interpretação, não equivaleu a uma fase isolada do processo. Contudo, ela foi uma parte do conjunto de ações desse processo e ocorreu simultaneamente a outras fases. Foi nela que as informações coletadas durante o levantamento de dados foram analisadas e organizadas de maneira a auxiliar na compreensão do problema (VIANNA et al., 2012). A área circundada pelo pontilhado azul, na Figura 2, apresenta o benchmarketing ${ }^{1}$ e a pesquisa de campo como o meio de reconhecer o que o mercado tem oferecido em situações similares às do museu. Tais situações se referem à procura de transmitir a identidade de um determinado local em artefatos que o representem e, ao serem adquiridos, são levados para outros locais.

\footnotetext{
${ }^{1}$ Análise das melhores técnicas e processos já em prática no mercado, segundo Baxter (2011, p. 187).
} 
Descobriu-se tal similaridade em projetos como Bicho do Mar de Dentro, proveniente da área da Lagoa dos Patos, no sul do Rio Grande do Sul, e também no projeto orientado pelo Laboratório Piracema de Design com os artesãos de Inhamuns, no sudoeste do Ceará. Encontrou-se, contudo, no projeto Sou Curitiba Souvenirs o exemplo ideal a ser analisado, seja pelas características presentes do projeto, seja pela possibilidade econômica de se visitar as lojas, seja pela proximidade geográfica do local, que oportunizou os autores conhecer os espaços do projeto com os produtos sendo comercializados. O projeto Sou Curitiba Souvenirs é um projeto de economia criativa e entre os seus objetivos está produzir um conjunto de produtos que tenham qualidade e atender às necessidades e aos desejos dos turistas, de modo a materializar as experiências vividas e fortalecer os laços com a cidade.

A pesquisa detalhada do benchmarketing enfatizou o uso de técnicas como a serigrafia e o corte a laser, bem como oportunizou considerar uma ampla variedade de materiais que pudessem receber tais aplicações, como o papel, a cerâmica e o tecido, por exemplo. Compreendeu-se que o processo resultante de produção não é restrito a ser industrial e/ou artesanal. Pretendeu-se apenas que os artefatos fossem portadores da identidade cultural local e que pudessem ser comercializados na loja de souvenires; do Museu Nacional do Mar, permitindo que o conjunto de símbolos locais se tornasse universal, ultrapassando a localização geográfica na qual se encontra inserido.

A fase de ideação, representada na Figura 2 como a de fundo cor-de-rosa, foi aquela em que se buscou gerar "ideias inovadoras através de atividades colaborativas que estimulem a criatividade" (VIANNA, 2012, p. 17). Para tanto, fez-se uso de ferramentas de síntese e gerou-se soluções que estivessem em conformidade com 
o contexto trabalhado no projeto. Considerou-se que os produtos escolhidos oferecessem perspectivas de vendas, ou seja, deveriam ser mensageiros do conteúdo do Museu Nacional do Mar e levar tal mensagem com quem adquirisse os artefatos, bem como os produtos deveriam ser eficientes para o seu transporte durante uma viagem, uma vez que os frequentadores do Museu são turistas. Critérios de tamanho, peso e resistência se apresentaram como sendo primordiais entre as características que os produtos deveriam ter. Somaram-se a esses critérios as características do museu e os princípios do design thinking: ser rentável para o museu, desejável para os turistas e tecnicamente possível de ser confeccionado.

A pesquisa de benchmarketing apresentou uma variedade de produtos formulados com os mais diferentes materiais e por meio das mais diversas técnicas, de maneira a responderem favoravelmente a esses critérios. Essa observação direcionou a escolha de alguns produtos a serem trabalhados. Foram eles: uma bolsa, uma caderneta de anotações e uma caneca. Esses produtos foram escolhidos por atenderem aos critérios comerciais estabelecidos; por serem produtos comumente consumidos por compradores; por serem confeccionados com técnicas bem difundidas; e por possuírem qualidades funcionais e estéticas, relacionadas com o uso e com o significado simbólico respectivamente. Também favoreceram o uso de três diferentes materiais: o tecido, o papel e a cerâmica.

Com o intuito de aplicar o design de superfície em artefatos que sejam souvenirs e torná-los atraentes, para que sejam comprados e levados para outros lugares, observou-se que para as perspectivas de aplicação dos desenhos gerados devia-se levar em consideração que as formas, os traços e as cores presentes nas peças de exposição do Museu Nacional do Mar fossem percebidas nos novos artefatos. Para tanto, uma cartela de cores foi montada a partir das cores 
presentes no museu, além de painéis contendo imagens das embarcações e detalhes de seus grafismos. Esboços foram feitos sobre essas observações e formas foram desenhadas e vetorizadas. Elas se apresentaram como elementos visuais a compor designs de superfícies pela repetição e fazendo uso de efeitos de translação ${ }^{2}$, rotação ${ }^{3}$ e reflexão ${ }^{4}$. Tal ação oportunizou a criação de 88 alternativas, como pode ser notado nos exemplos da Figura 3.

Figura 3 - Geração de alternativas

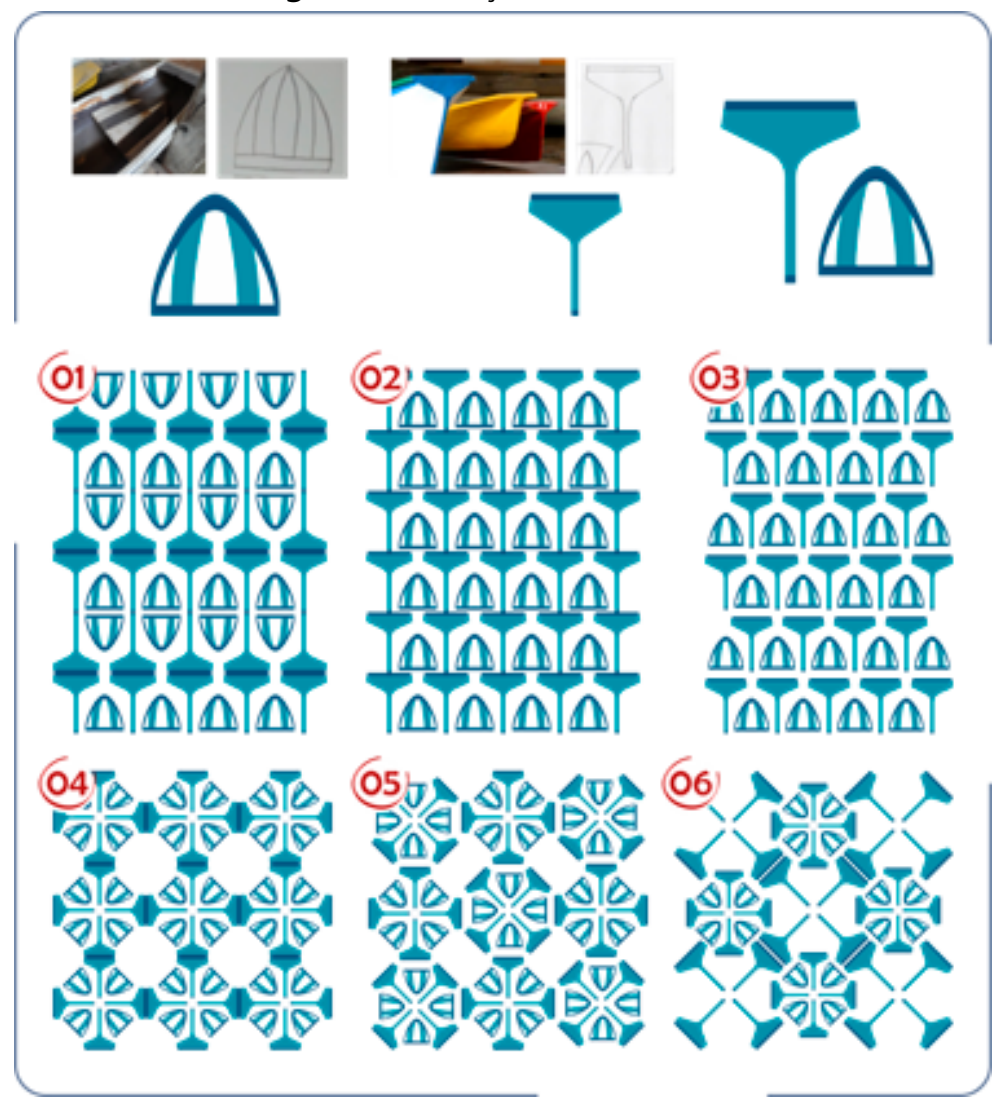

Fonte: primária (2015)

2 O módulo mantém sua direção original e desloca-se sobre um eixo (RÜTHSCHILLING, 2008, p. 68).

${ }^{3}$ Deslocamento radial do módulo ao redor de um ponto (Id. Ibid., p. 68).

${ }^{4}$ Espelhamento em relação a um eixo ou a ambos (Id. Ibid., p. 68). 
A fim de compor uma minicoleção de designs de superfície, selecionou-se dez alternativas entre as 88 geradas. Para isso, utilizou-se a matriz de decisão, baseada em Baxter (2011), como ferramenta de seleção. A partir de sua aplicação, as alternativas com maior pontuação foram selecionadas para compor os desenhos de superfície desse projeto. Elas podem ser vistas na Figura 4 e esse conjunto de alternativas selecionadas se apresenta como desenhos barrados e metragens corridas.

Figura 4 - Alternativas selecionadas

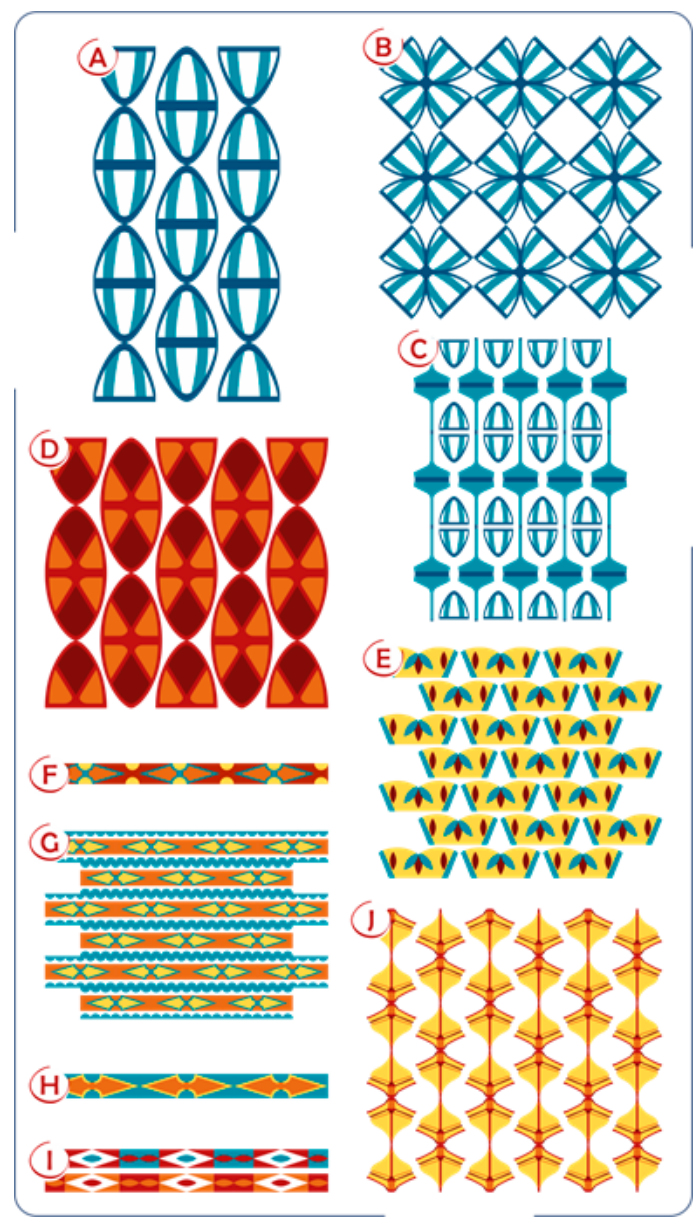

Fonte: primária (2015) 
Cores quentes como vermelho, alaranjado e amarelo contrastam com as cores frias, como os tons de azul. A cor branca soma ao grupo de cores utilizadas e sugere leveza, remetendo à simplicidade da vida ao mar. As formas enfatizam detalhes encontrados no acervo do Museu Nacional do Mar.

Ao definir-se os produtos a serem confeccionados e os designs de superfície a serem aplicados, a fase da prototipação teve início. Ela esteve relacionada com o momento em que as ideias geradas foram materializadas e experimentadas por meio de protótipos, de maneira que fossem refinadas e validadas. Os produtos selecionados durante a fase de ideação tiveram diferentes especificações, como se pode observar na Figura 5.

Figura 5 - Especificações dos produtos confeccionados

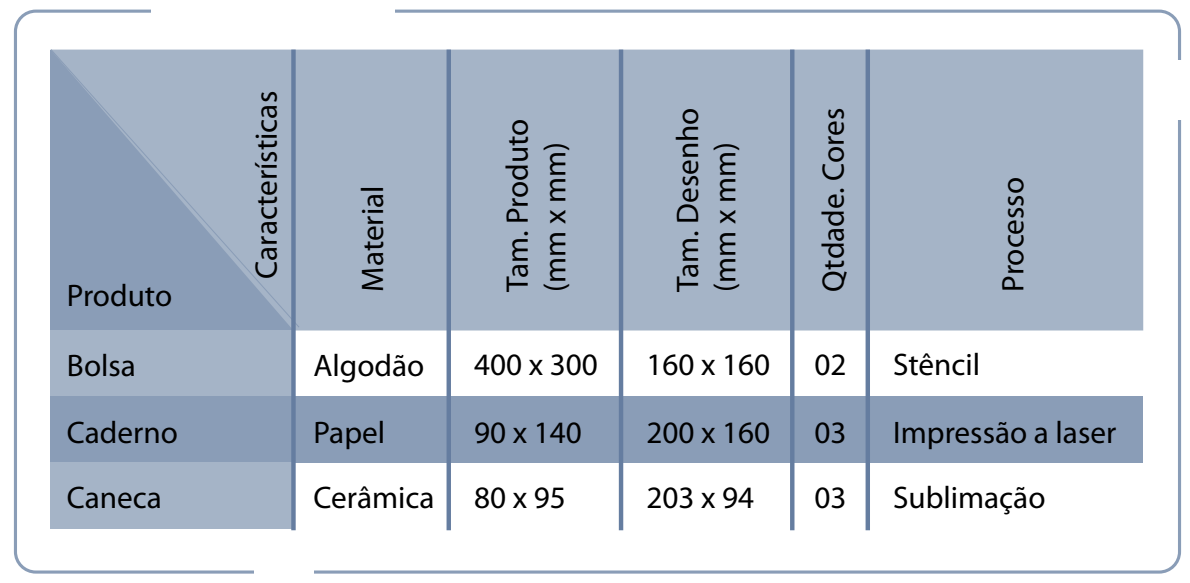

Fonte: primária (2015)

A Figura 6 apresenta os produtos confeccionados. São modelos físicos que foram prototipados para uma melhor visualização e possível adequação para futuras implantações do projeto. Este projeto pode seguir variados desdobramentos, contudo ele se encerrou com a fase de prototipação das peças e sua apresentação. 
Figura 6 - Produtos confeccionados

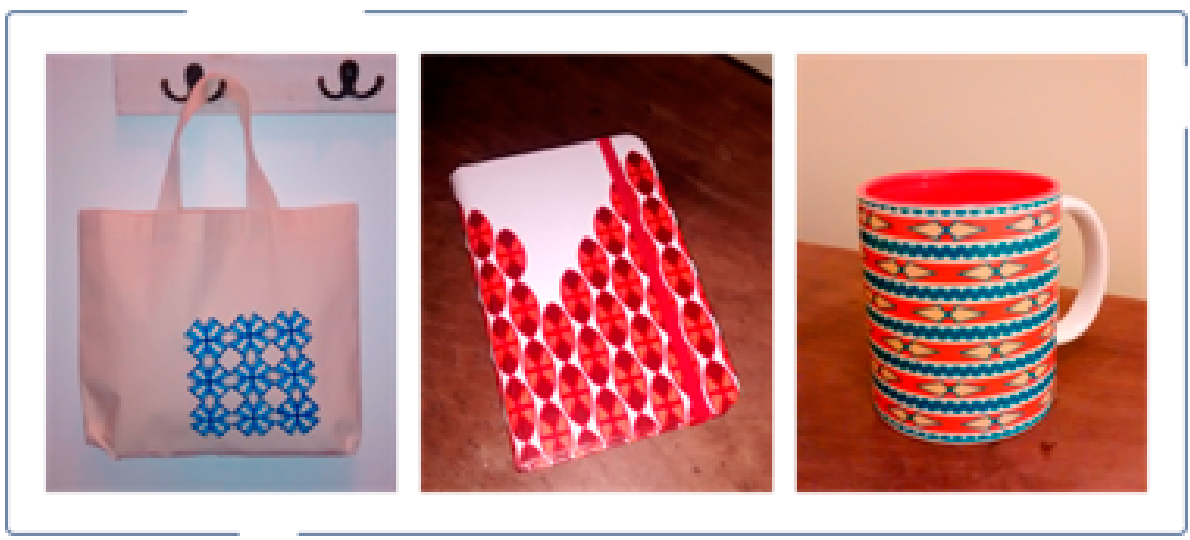

Fonte: primária (2015)

O seu objetivo principal, que era reapresentar o Museu Nacional do Mar por meio do design de superfície para criação de artefatos que valorizassem sua identidade cultural, foi alcançado.

\section{CONSIDERAÇÕES FINAIS}

O imenso tamanho e a trajetória histórica proporcionam ao Brasil variados contextos culturais. A cidade de São Francisco do Sul é um deles e detém parte desse vasto acervo cultural e histórico nacional. Além disso, é nela que está localizado o Museu Nacional do Mar, tema de inspiração deste projeto.

Muitas vezes, a atuação da globalização em unificar acaba por descaracterizar locais e faz com que peculiaridades pertencentes a espaços como o do museu não se tornem conhecidas e universais. Logo, em vista de valorizar o conteúdo exposto no museu, ressignificálo e permitir que ele se estenda além de suas fronteiras, surgiu a seguinte problemática que foi trabalhada neste projeto: como utilizar o design de superfície para contribuir com a valorização do museu por meio da criação de artefatos? 
A fim de que uma solução fosse encontrada, buscou-se referências na cidade em que o museu se encontra, bem como no próprio espaço do museu. Para que a sua valorização fosse alcançada, o design de superfície foi a atividade criativa utilizada para reforçar a identidade cultural do local; e o design thinking, a ferramenta de inovação escolhida. Evidencia-se dessa maneira que o projeto foi fundamentado em quatro temas - cidade de São Francisco do Sul e Museu Nacional do Mar; identidade cultural; design de superfície; e design thinking. A sua exploração estruturou o projeto de maneira a apresentar seus assuntos e sequenciar todo o conteúdo do projeto. As pesquisas bibliográfica, simbólica e de produtos foram utilizadas, caracterizando a pesquisa como qualitativa de caráter exploratório e também como pesquisa participante.

Como ferramenta de inovação, o design thinking permitiu que as diferentes pesquisas fossem distribuídas nas quatro etapas sugeridas pela ferramenta. Essa ação concedeu organização ao desenvolvimento do projeto e auxiliou na escolha dos artefatos elaborados e portadores dos desenhos gerados.

Os princípios do design thinking deram suporte para que os produtos finais - bolsa, caderneta de anotações e caneca - fossem concebidos a partir da observação de serem viáveis tecnicamente na sua confecção, rentáveis financeiramente e desejáveis para os visitantes do museu.

A sustentabilidade cultural e financeira do museu é alcançada quando os artefatos produzidos são: portadores da identidade da cultura local, comercializados na loja de souvenirs e adquiridos pelos turistas que acabam por promover o museu. Dessa forma, oportuniza-se a criação de uma renda alternativa para o museu e traz contribuição cultural para a sociedade, uma vez que sensibiliza o Museu Nacional do Mar para as questões simbólicas e de sua 
identidade cultural. Acredita-se que o projeto desenvolvido reforçou o vasto acervo cultural do museu e valorizou o seu conjunto de símbolos locais por meio da emoção e por possibilitar que estes ultrapassem a localização geográfica na qual estão inseridos.

A oportunidade de aprofundar no processo de investigação para inovação une o reduto cultural que o museu representa ao Design de Superfície. $O$ acervo não apenas agregou com sua riqueza de informações ao projeto - sua singularidade-como também contribuiu na sua valorização e preservação diante do registro a ser realizado, tornando-se universal. Tal reapresentação de seus aspectos combinados ao Design de Superfície fez uso de suportes nos quais suas superfícies fossem elaboradas por meio do estudo de grafismos, cores, materiais e técnicas de aplicação.

A possibilidade de se trabalhar com o museu e com o Design de Superfície retoma estudos já realizados pelos autores. O desafio de procurar mais respostas sob um novo olhar oportunizou que os detalhes presentes nas peças expostas no museu pudessem se destacar e ser fonte primordial para a criação de novos desenhos a serem aplicados em diferentes artefatos. Fazer uso da identidade cultural presente no acervo do museu, valorizá-la e ressignificá-la por meio da aplicação de suas cores, formas e traços em designs de superfície, representando a simplicidade da vida dos homens que lidam no mar, foram os critérios estabelecidos ao projeto para alcançar os resultados.

Observa-se a possibilidade em dar continuidade com a pesquisa e estendê-la a projetos futuros a fim de que seja aplicada no Museu Nacional do Mar. Pretende-se também que o material gerado seja publicado e contribua com pesquisas para a comunidade acadêmica e profissional. 


\section{REFERÊNCIAS}

BAXTER, M. Projeto de produto: guia prático para o design de novos produtos. 3. ed. São Paulo: Blucher, 2011.

BORGES, A. Design + Artesanato: o caminho brasileiro. São Paulo: Terceiro Nome, 2011.

EDGAR, A.; SEDGWICK, P. Teoria da cultural de A a Z: conceitos-chave para entender o mundo contemporâneo. São Paulo: Contexto, 2003.

ENGELS, F. et al. $\mathbf{O}$ papel da cultura nas ciências sociais. Porto Alegre: Editorial Villa Martha Ltda., 1980.

FREIRE, P. À sombra desta mangueira. São Paulo: Olho Dágua, 2001.

GEERTZ, C. A interpretação das culturas. Rio de Janeiro: Zahar, 1978.

GERHARDT, T. E.; SILVEIRA, D. T.. Métodos de pesquisa. Porto Alegre: Editora da UFRGS, 2009.

GIL, Antonio Carlos. Métodos e técnicas de pesquisa social. 6. ed. São Paulo: Atlas, 2008.

MARCONI, M. A.; LAKATOS, E. M. Fundamentos de metodologia científica. 5. ed. São Paulo: Atlas, 2003.

RÜTHSCHILLING, E. A. Design de superfície. Porto Alegre: Editora da UFRGS, 2008.

SOU CURITIBA. Souvenirs. Disponível em: <http://sites.pr.sebrae. com.br/soucuritiba/>. Acesso em: 14 set. 2014.

VIANNA, M. et al. Design Thinking: inovação em negócios. Rio de Janeiro: MJV Press, 2012. 



\section{Design \& embalagens: um estudo de caso da indústria Itálica}

Luis Eduardo de Souza (Currículo Lattes) Marli Teresinha Everling (Currículo Lattes)

\section{INTRODUÇÃO}

A microindústria de alimentos congelados para a qual se realizou este estudo está situada em Joinville/SC, foi fundada em setembro de 1993 e atua há mais de vinte anos na produção e comercialização de massas alimentícias e molhos congelados. Caracterizada como uma pequena indústria familiar, é conduzida pelo casal de sóciosproprietários e produz, de forma caseira, uma média de três mil quilos de alimento por mês.

A empresa conta atualmente com 30 pontos de venda (distribuídos entre cidades de Santa Catarina e na cidade de Curitiba/ 
PR) e tem um portfólio composto por vinte produtos, divididos nas Ilinhas: (1) de produtos que vão direto ao forno, (2) de produtos que recebem molho e vão ao forno e (3) de molhos prontos. A Figura 1 descreve quais produtos compõem as linhas de produtos existentes.

Figura 1 - Linha de produtos

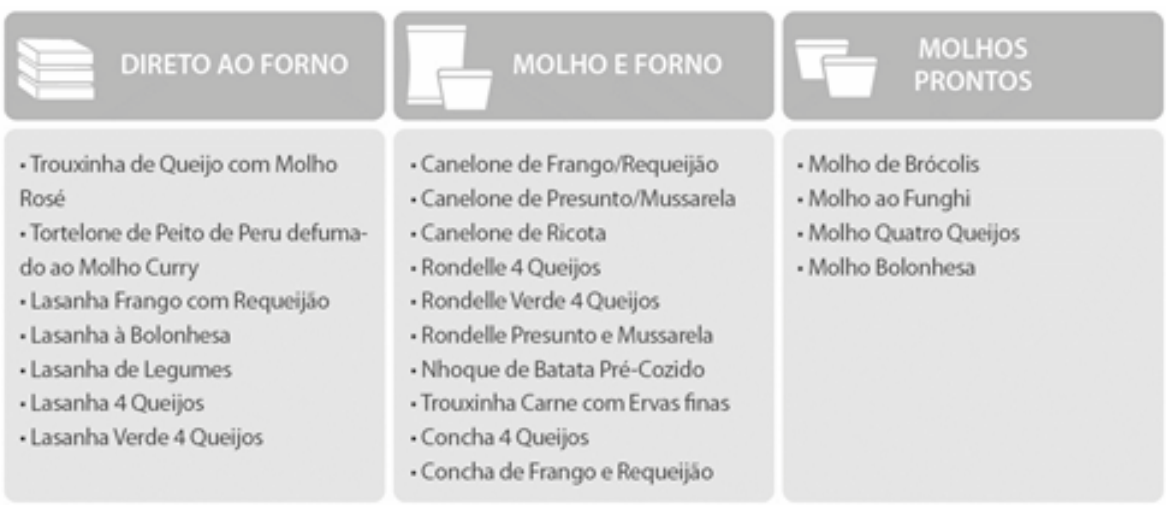

Fonte: arquivo pessoal

A sócia-proprietária da indústria relatou que a última atualização das embalagens se deu em 2007 e foi direcionada apenas na linha Direto ao Forno, sendo que as demais embalagens não são atualizadas desde 2004.

A etapa da pesquisa aqui relatada visou o mapeamento de problemas associados a Relações de Uso, Design Centrado no Usuário (DCU) e Design de Informação, com foco no uso das embalagens da indústria em questão. Já o procedimento utilizado consistiu uma experiência imersiva ${ }^{1}$ de uso. Como parte do processo de investigação os autores da pesquisa (e designer) realizou a experiência do uso de dois de seus produtos, com o intuito de ampliar a percepção acerca

\footnotetext{
${ }^{1}$ Para a experiência imersiva de uso, foi realizado um estudo em que considerou todo o processo de consumo do produto, desde a compra no supermercado, passando pelo manuseio das embalagens, preparo dos alimentos, até o descarte dos resíduos.
} 
de problemas e traçar recomendações preliminares no intuito de possibilitar o aprofundamento das etapas de pesquisa com outros usuários. A abordagem partiu da premissa que a negligência de aspectos relacionados ao uso de embalagens (ou de configurações que sugerem o uso indevido), associados às funcionalidades deficientes e comunicação visual falha, podem ocasionar problemas como desperdício do produto e uso inadequado.

\section{RELAÇÕES DE USO E USABILIDADE}

O termo Relações de uso diz respeito à usabilidade, ou seja, de que forma se dá o relacionamento do usuário com algum produto, sistema ou serviço. Preece et al. (2013, p. 18) afirmam que pela perspectiva do usuário "usabilidade visa assegurar que produtos interativos sejam fáceis de aprender a usar, eficazes e agradáveis".

Todo produto ao ser utilizado gera uma relação de uso entre o objeto e o usuário, e cabe ao desenvolvedor do produto otimizar as interações permitindo ao usuário realizar suas atividades de forma plena e segura. Segundo Preece et al. (2013, p. 18), a usabilidade é dividida nas seguintes metas: ser eficaz no uso (eficácia); ser eficiente no uso (eficiência); ser segura no uso (segurança); ter boa utilidade (utilidade); ser fácil de aprender (learnability); ser fácil de lembrar como usar (memorability). Para os autores tais metas podem ser utilizadas em forma perguntas, tendo o objetivo de fornecer ao designer possibilidades de avaliar os aspectos de um produto e a experiência de uso.

Com o objetivo de definir critérios para o projeto de embalagem, buscou-se categorizar aspectos relacionados a relações de uso; para tal foram utilizados os princípios de usabilidade sob a ótica do design. Esses princípios foram propostos por Preece et al. (2013) e ampliam a 
perspectiva proposta, inicialmente, por Norman (2006) em seu livro O Design do dia a dia. Para Preece et al. (2013, p. 25), “os princípios de Design são derivados de uma mistura de conhecimento baseado em teoria, experiência e bom senso".

A partir dos princípios propostos por Norman e Preece et al. (visibilidade, feedback, restrições, mapeamento, consistência e affordance), suas definições são apresentados na Figura 2 a seguir.

Figura 2 - Princípios de design

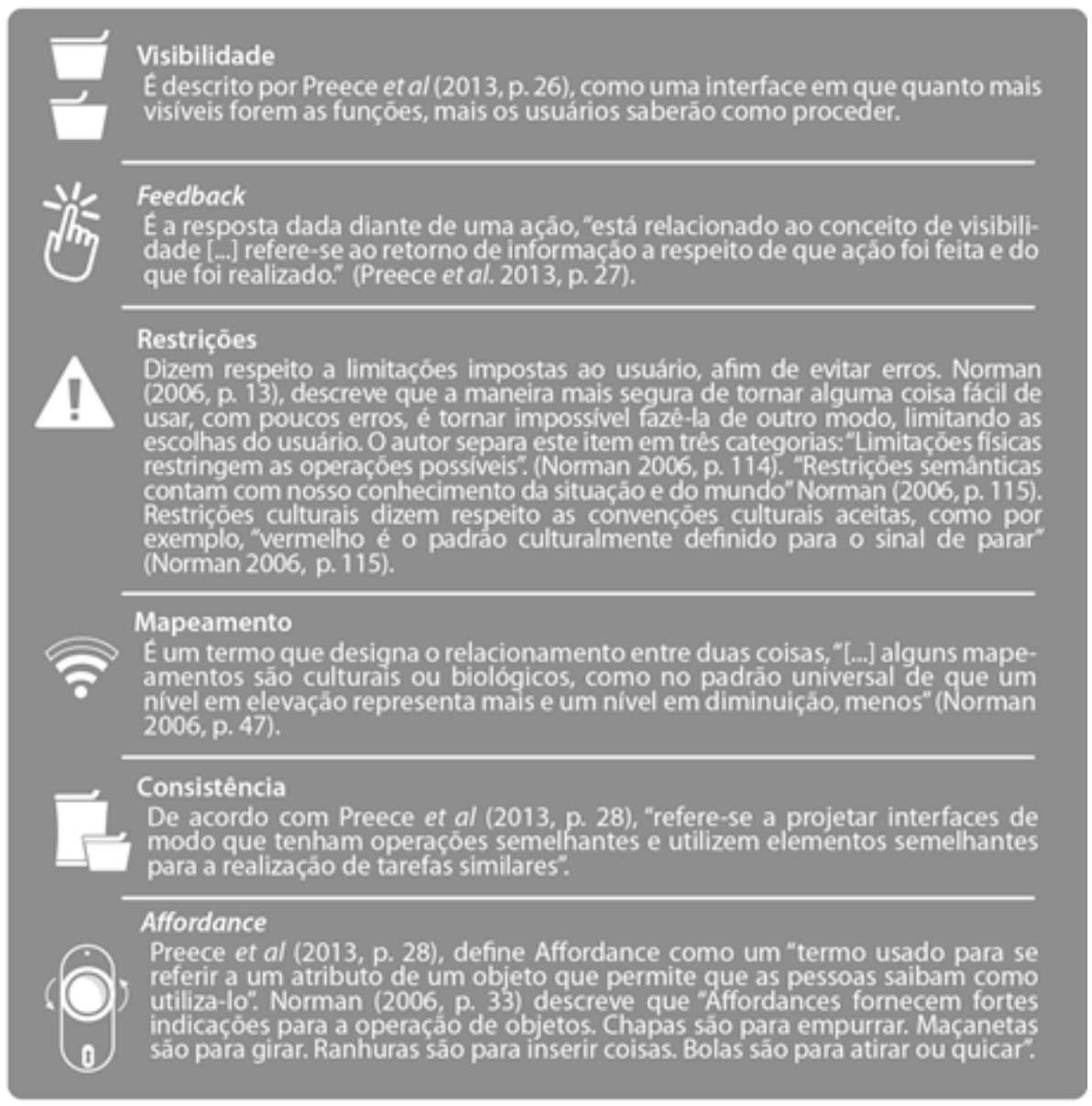

Fonte: baseada em Preece et al. (2013) e Norman (2006) 
Ao Aplicar esses conceitos a um projeto de embalagens, é possível avaliar diversos aspectos, como, por exemplo: quão eficiente e eficaz é a embalagem em relação ao uso? Quão seguro é o uso dela? O quão eficiente é sua comunicação e seu formato? O quão útil é seu propósito? Qual o nível de dificuldade em entender rapidamente sua utilização? E, por último, qual o nível de dificuldade existente em lembrar como utilizá-la?

Além dos aspectos anteriormente citados, ao mapear as relações de uso possíveis ou existentes em determinada situação, deve-se atentar para questões do entorno, como: avaliar o uso intuitivo da embalagem (de modo direto e instantâneo, sem auxílio de regras), uso prescrito (usos previstos pelo desenvolvedor) versus o uso real (usos reais que podem ser diferentes do prescrito) e variedade de interações ao longo do ciclo de vida (que considera questões além da usabilidade, como transporte, manutenção, pós-venda etc.).

\section{DESIGN INFORMACIONAL}

Design informacional está relacionado à apresentação e representação de informações de uma forma visual. Para este projeto de embalagem, optou-se por abordar esse tema com o objetivo de categorizar problemas percebidos em relação à visibilidade, legibilidade, compreensibilidade de signos visuais, problemas de percepção, decodificação, navegação e aprendizagem em relação à comunicação da embalagem.

Para a categorização dos problemas informacionais da embalagens, foram utilizados os critérios informacionais/ visuais e cognitivos propostos por Moraes e Mont'alvão (2009) e recomendações de representação da informação visual propostas por Mijksenaar e Westendorp (1999) no livro Open Here. 
De acordo com Moraes e Mont'alvão (2009, p. 131), problemas informacionais e visuais dizem respeito a "deficiências na detecção, discriminação e identificação de informações em telas, painéis, mostradores e placas de sinalização, resultantes da má visibilidade, legibilidade e compreensibilidade de signos visuais, com prejuízos para a percepção e para a tomada de decisões". Já problemas cognitivos, segundo as autoras, dizem respeito à:

dificuldade de decodificação, aprendizagem, memorização em face de inconsistências lógicas e de navegação dos subsistemas comunicacionais e dialogais, que resultam em perturbações para a seleção de informações, para as estratégias cognoscitivas, para a resolução de problemas e para a tomada de decisões (IBID).

Esses critérios podem contribuir para um projeto de embalagem de alimento em que há informações variadas, tais quais modo preparo, uso correto do produto, características do produto, modo de conservação, prazo de validade, restrições de uso, sugestões de preparo, entre outras.

Mijksenaar e Westendorp (1999) contribuem com o estabelecimento de critérios que podem orientar a representação de informações visuais ampliando a eficácia da comunicação; buscouse esse referencial no intuito de considerar cuidados que o designer deve tomar ao planejar instruções visuais para as embalagens; o esquema chamado de Elementos Engenhosos, proposto pelos autores, é apresentado na Figura 3 a seguir. 
Figura 3 - Elementos engenhosos

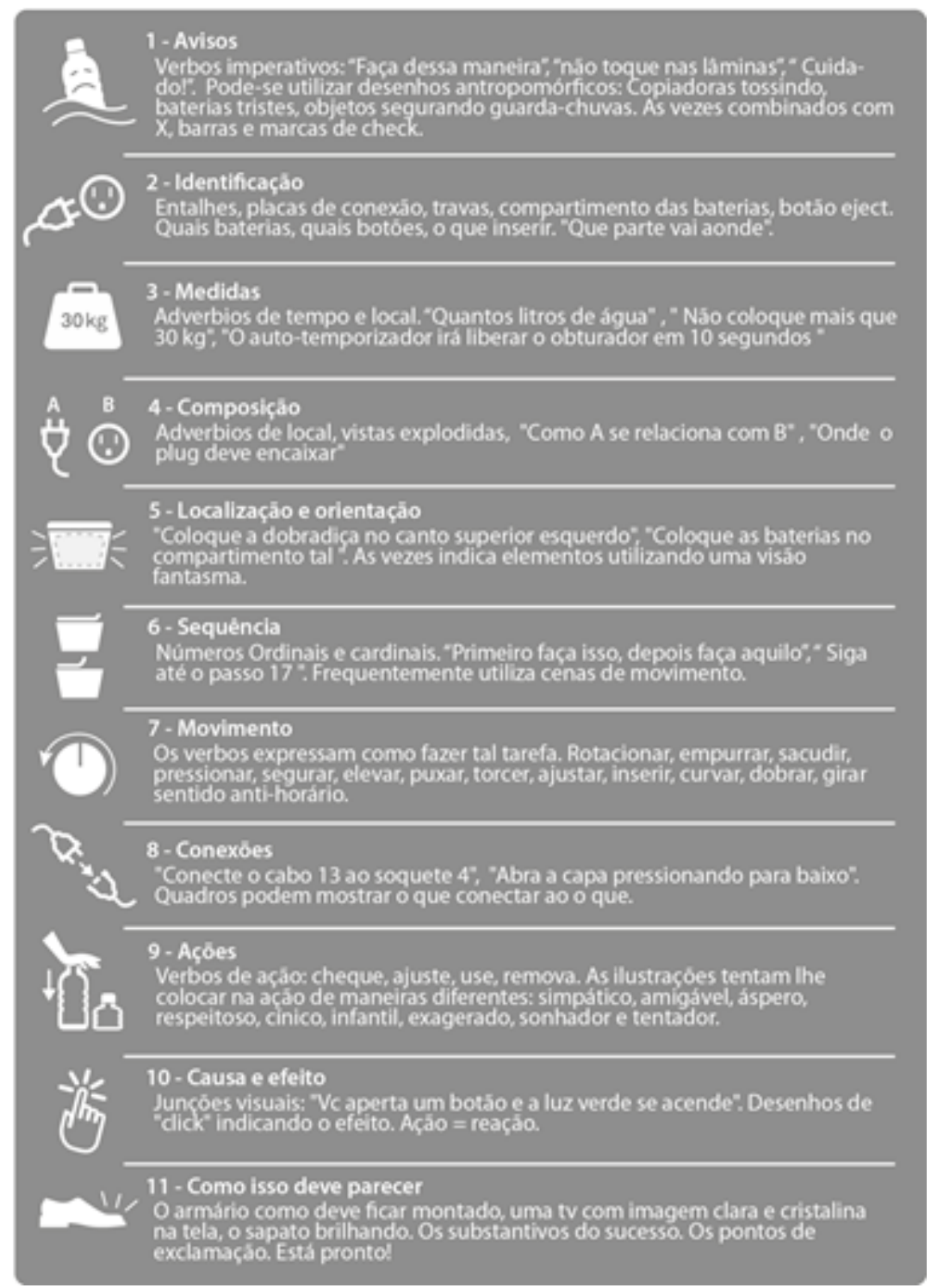

Fonte: baseada em Mijksenaar e Westendorp (1999, p. 56-139)

A abordagem proposta por Mijksenaar e Westendorp foi desenvolvida para ser aplicada em produtos de forma geral, sendo que nem todos os produtos e embalagens necessitam seguir todos 
os onze passos. Entretanto, a apresentação de um produto (ou embalagens), por mais comum e reconhecido que ele seja, deve ser feita de forma clara, garantindo que qualquer usuário possa utilizar e entender aquele produto, conforme argumentam os autores:

Produtos nunca irão falar por si só. Alguém terá que nos ensinar que uma cadeira é para sentar em cima, que uma colher é para colocar comida na boca. Utilizar essas coisas parece intuitivo porque aprendemos sobre elas desde a infância. Mas imagine ver um pedaço achatado de madeira curva com cantos arredondados pela primeira vez. Você saberia dizer para que um bumerangue serve? E como utilizá-lo? Alguém que nunca tinha visto um garfo antes entenderia que aquilo é utilizado para comer? (MIJKSENAAR; WESTENDORP, 1999, p. 13).

A lista de onze elementos engenhosos, proposta por Mijksenaar e Westendorp, aplicados a um projeto de embalagem, visa ampliar possibilidades que o usuário tenha, de forma clara e objetiva, todas as informações necessárias para se relacionar adequadamente com sua utilização. A Figura 4 abaixo apresenta exemplos de embalagens que o uso intuitivo foi facilitado.

Figura 4 - Embalagens intuitivas

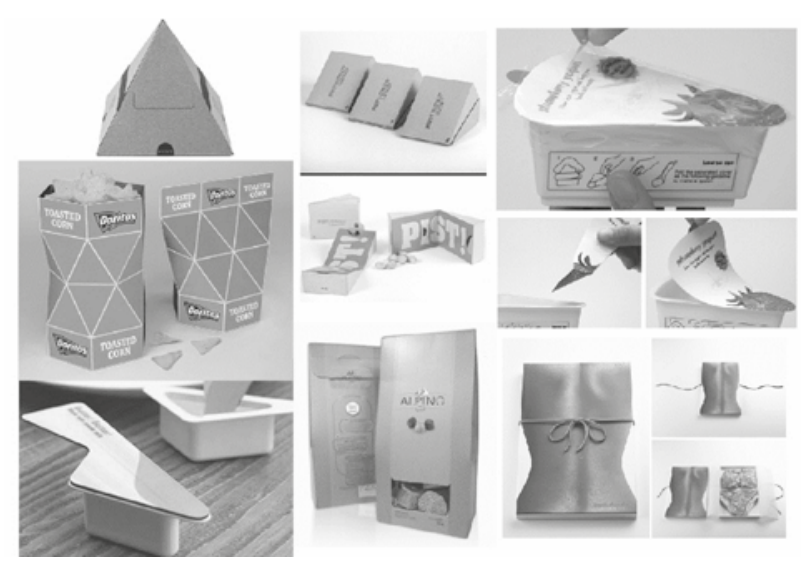

Fonte: arquivo pessoal, baseada em sites diversos 
As embalagens apresentadas anteriormente exemplificam algumas possibilidades do direcionamento para um uso intuitivo devido ao formato, linhas, cores e materiais. Observando o painel, percebe-se a utilização de elementos que sugerem ações, tais como: abas são para puxar, vincos para dobrar, linhas tracejadas para romper e laços para desatar.

\section{SUSTENTABILIDADE}

Para este projeto, sustentabilidade engloba critérios ambientais envolvidos no ciclo de vida de um produto. A autora Wendy Jadlicka, em seu livro Packaging Sustability: Tools, Systems and Strategies for Innovation Package Design, argumenta que as pessoas costumam enxergar as coisas que as rodeiam da mesma maneira linear que é a sua existência: nascimento, vida e morte.

\footnotetext{
As coisas são fabricadas, nós utilizamos e depois jogamos fora. Mas não existe este "fora". Produtos e embalagens têm vida após serem utilizados, seja como lixo (depósitos de lixo ou incineração), ou seja como parte de um novo objeto (reciclados ou reutilizados). Quando objetos renascem (reciclados ou recuperados) e são colocados novamente no sistema, isso se torna um consumo circular que imita a natureza: criar, usar e recriar sem limitações (JADLICKA, 2008, p. 2, tradução livre).
}

Os autores McDonough e Braungart (em seu livro 'Cradle to Cradle-criar e recriar ilimitadamente') compartilham desse pensamento ao abordar o tema ecoeficiência; os autores defendem a necessidade de uma mudança global de pensamento do atual 'do berço à cova' (tradução do termo cradle to grave usado para designar um ciclo de vida linear de produto chegando a um 'fim'), para a concepção ideal do berço ao berço (tradução do termo cradle 
to cradle, que designa produtos criados para serem realocados novamente na cadeia produtiva ou na cadeia orgânica).

\begin{abstract}
Os projetos do modelo cradle to grave dominam a fabricação moderna. De acordo com algumas estimativas, nos Estados Unidos, mais de $90 \%$ dos materiais extraídos para a elaboração de bens duráveis transformam-se lixo quase que imediatamente (MCDONOUGH; BRAUNGART, 2013, p. 34).
\end{abstract}

Para este projeto de embalagem, o tema sustentabilidade visa categorizar problemas ambientais percebidos, que devem ser considerados para minimizar o impacto ambiental provocado pelas embalagens e tornar o produto o mais sustentável possível dentro da realidade da Itálica.

Critérios ambientais ao longo da história vêm evoluindo e se adequando para suprir as necessidades existentes. Segundo Zavadil e Silva (2013, p. 41), a fórmula conhecida como os 3 Rs (Reduzir, Reutilizar e Reciclar) foi atualizada para os 5 Rs (Restaurar, Respeitar, Reduzir, Reutilizar e Recuperar), em que o termo 'Reciclar' deu lugar para o termo'Recuperar', pois “[...] a reciclagem sem reaproveitamento dos recursos materiais e energéticos ainda é apenas um resíduo."

Jadlicka (2008) apresenta as metas de redução de impacto ambiental $7 \mathrm{Rs}$, propostas pela rede WalMart (rede americana de supermercados). Essa proposta pode ser considerada como uma evolução do método dos 5 Rs, tendo o objetivo de se adequar a novos hábitos e envolver seus fornecedores. A autora prossegue argumentando que, "como muitas outras ideias sustentáveis em uso atualmente, o sistema de 7 Rs da WalMart são metas que continuam mudando e melhorando continuamente" (JADLICKA, p. 204). Zavadil e Silva também discutem o sistema adotado: 
Nos últimos anos, a multinacional do varejo WalMart vem investindo em programas de sustentabilidade na sua política interna e com fornecedores, incluindo ações para a redução do impacto ambiental das embalagens. Assim, para atingir as suas metas de sustentabilidade, a rede WalMart estabeleceu 7 Rs a serem considerados por seus fornecedores no desenvolvimento e uso de suas embalagens (ZAVADIL; SILVA, 2013, p. 41).

Para ajudar a rede WalMart a atingir sua meta proposta pelo sistema 7 Rs, os fornecedores devem considerar as sete regras apresentadas na Figura 5 a seguir:

Figura 5 - Metas sustentáveis proposta pelo sistema 7 Rs

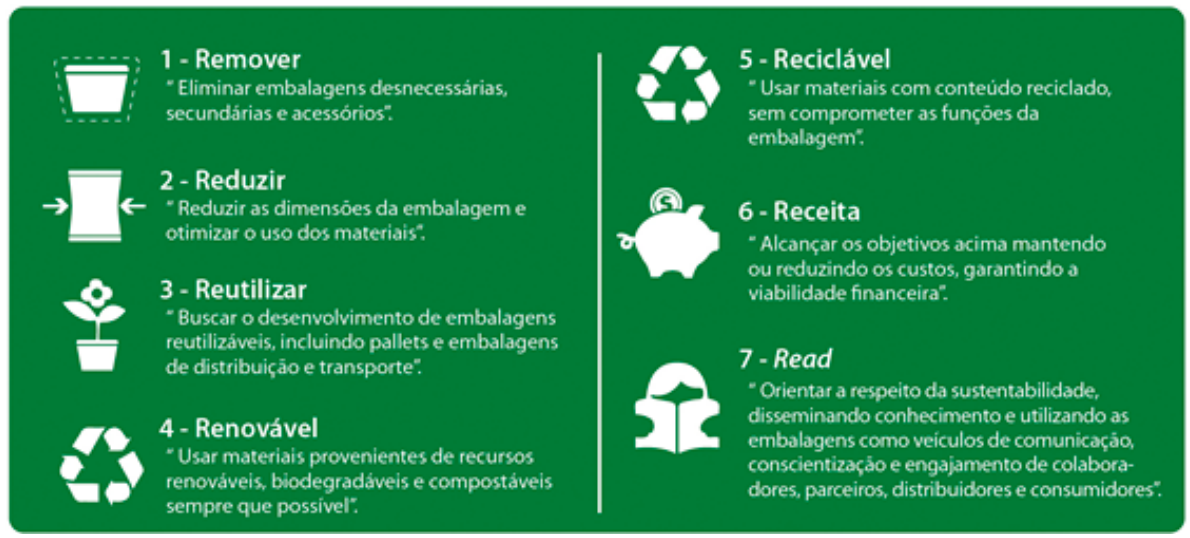

Fonte: baseada em Zavadil e Silva (2013, p. 41)

A escolha e aplicação dos 7 Rs neste projeto, conforme esquema utilizado pela empresa WalMart, se dá porque esse método, além de definir metas a respeito de critérios ambientais como remover, reduzir, reutilizar, renovar e reciclar, define também as metas "receita"e "read", que dizem respeito às questões de âmbito econômico (viabilidade financeira) e social (educação por meio da embalagem), itens que são de interesse da indústria Itálica e do Programa de Mestrado em Design. Além das citadas metas, também é possível reduzir o 
impacto ambiental de uma embalagem, restringindo o uso de tinta na sua rotulagem ou utilizando tintas também com característica biodegradável. A Figura 6 abaixo apresenta embalagens que utilizam materiais sustentáveis em sua composição, como fibras e cascas, e traz exemplos de embalagem biodegradáveis, que reduzem significativamente o impacto ambiental gerado por resíduos de embalagens.

Figura 6 - Embalagens sustentáveis
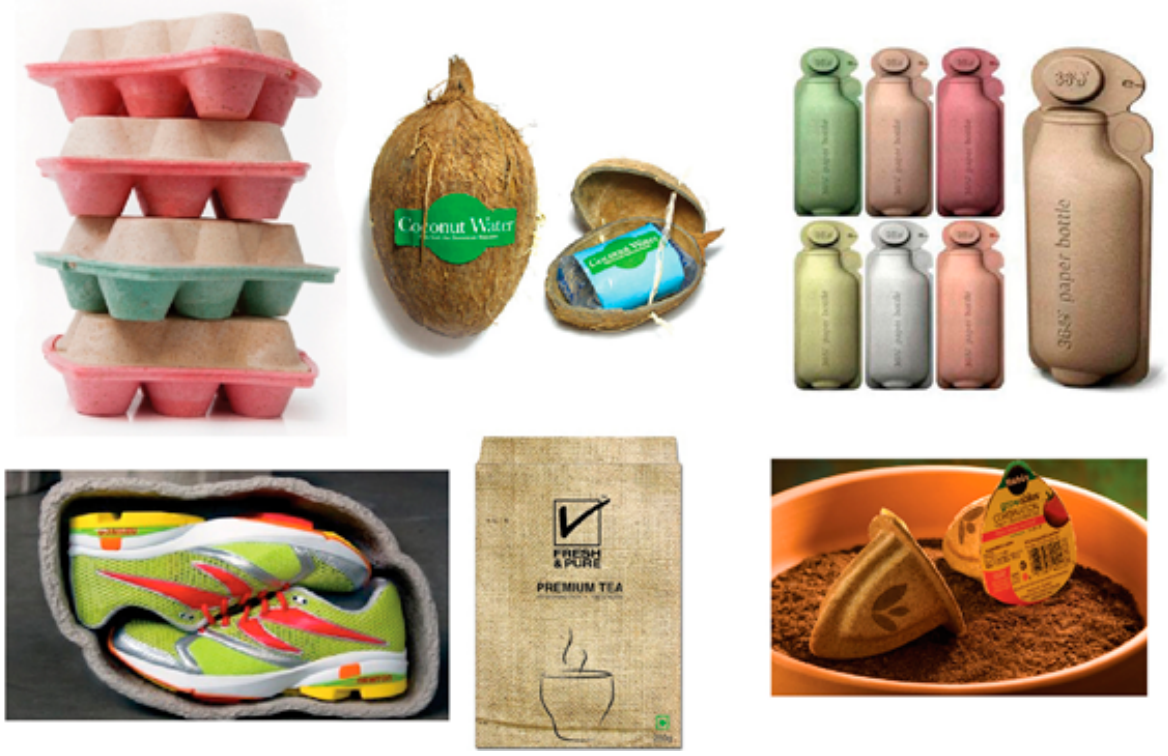

Fonte: arquivo pessoal, baseado em sites diversos

Considerando um projeto de embalagens, além da remoção e redução de elementos secundários e desnecessários, do uso de materiais sustentáveis e da orientação quanto ao descarte correto, o reúso caracteriza uma solução relevante na diminuição do impacto ambiental gerado pelos resíduos das embalagens.

Porém, para facilitar o reúso, os produtos devem ser projetados e fabricados no intuito de viabilizar essas metas, como, por 
exemplo,facilitar a desmontagem. Com essa mesma intenção, Manzini e Vezzoli (2011, p. 201) afirmam que "as alterações necessárias para promover a reutilização devem ser poucas e limitar-se, por exemplo, à limpeza ou à desmontagem e recondução de alguns componentes para os novos produtos".

Para facilitar o reúso dos produtos, Manzini e Vezzoli (2011) listam sete indicações, apresentadas na Figura 7 a seguir.

Figura 7 - Indicações para facilitar o reúso

\section{Indicações para facilitar o reuso}

"Incrementar a resistência das partes

mais sujeitas a avarias e rupturas"

\section{" Predispor o acesso para facilitar a}

$2 \mid$ remoçāo das partes e componentes que podem ser reutilizados"

3 | Projetar partes e componentes | intercambiáveis e modulares "
$4 \mid$ "Projetar partes e componentes estandardizados"

$5 \mid$ "Projetar a reutilizaçāo de partes auxiliares"

$6 \mid$ "Projetar a possibilidade de recarga e/ou reutilização das embalagens"

7 | Projetar prevendo um segundo uso

Fonte: baseada em Manzini e Vezzoli (2011, p. 201)

As sete indicações vistas na Figura 7, dizem respeito a produtos de uma maneira geral; considerando embalagens, podemos explorar algumas indicações como: incrementar a resistência das partes mais sujeitas a rupturas, projetar a possibilidade de recarga ou reutilização das embalagens e projetar prevendo um segundo uso.

\section{METODOLOGIA}

A natureza deste projeto se caracteriza como pesquisa aplicada que, de acordo com Silva e Menezes (2005, p. 14), "objetiva gerar conhecimentos aplicáveis à prática e dirigidos à solução de 
problemas específicos". Considerando que o objetivo é propor uma solução de design para as embalagens das linhas de produtos Itálica (integrando o estudo das relações do design com realidade social, comportamento e o desenvolvimento de produtos sustentáveis que caracterizam a linha de pesquisa 'Produção do design e contexto sociocultural'), sua base técnico-científica apoia-se em teorias, métodos e procedimentos relacionados a relações de uso, design da informação e sustentabilidade.

De modo geral todas as metodologias de design são orientadas para solução de problemas, mas por se tratar de um relatório técnico, e no intuito de estabelecer uma conexão entre o processo de design, os procedimentos de pesquisa, optou-se por subdividir o processo metodológico em macro e microestruturas, contribuindo para a organização lógica dos procedimentos e do relato. Segundo De Brito (2004), os métodos de desenho têm sido entendido como a sequência alternada de dois processos elementares: a macroestrutura e a microestrutura.

Por macroestrutura entende-se a subdivisão do processo de desenho em etapas ou fases, estas dão orientação no procedimento do método. Por microestrutura se entende a descrição das especificações técnicas empregadas em cada uma das etapas ou fases, sendo que estas microestruturas oferecem técnicas e métodos que podem ser utilizados em certas etapas (DE BRITO, 2004, p. 37).

Outromotivo quejustificaesse desdobramentoéa customização do conjunto de procedimentos (microestrutura) associados a cada fase macroestrutural. Essa customização foi derivada das abordagens pretendidas (relações de uso, design da informação e sustentabilidade) e pode ser útil em projetos com enfoques similares. Destaca-se ainda que ao longo do relato o termo fase refere-se aos tópicos da macroestrutura enquanto o termo etapa reporta ao 
conjunto de procedimentos que compõem a microestrutura (cada fase poderá ter mais do que uma etapa).

\section{MACROESTRUTURA}

Para delinear a macroestrutura fez-se uma análise comparativa das estruturas propostas pelos autores Bonsiepe (1984, 2010), Bürdek (2010), De Brito (2004), Löbach (2001), Mestriner (2001, 2002), Meurer e Szabluk (2008) e Tennyson e Alt (2011). Nessa seleção procurou-se buscar autores de abordagens clássicas e contemporâneas.

Com o objetivo de integrar fases e etapas de abordagens clássicas e contemporâneas, da intersecção universidade-empresa desta investigação, da natureza do mestrado em Design da Univille que se caracteriza como profissional, e da intenção de inserir ferramentas e técnicas associadas ao design centrado em usuários ${ }^{2}$, inclui-se, na análise comparativa, estruturas propostas pelas empresas de design IDEO (HCD Toolkit) e Frog Design (Collective Action Toolkit). A Figura 8 permite a visualização das similaridades e divergências dos processos metodológicos de cada autor selecionado. As cores usadas sinalizam a subdivisão das macrofases de desenvolvimento de produto; no primeiro nível de agrupamento (em rosa) estão as fases associadas ao levantamento de informações; no segundo nível (em amarelo) constam fases relacionadas ao planejamento; no terceiro nível (em verde) estão sinalizadas as fases de projeto e de geração de alternativas; no quarto nível de agrupamento (em azul) está marcada a única fase associada a implementação do projeto

\footnotetext{
2 Optou-se por abordagens qualitativas e imersivas mais próximas do design centrado no usuário e ao design participativo (como o HCD Toolkit e Collective Action Toolkit) ao invés do design thinking devido à ênfase deste relatório em aspectos relacionados ao uso. Apesar dessa escolha, reconhecemos que há pontos de conexão entre as abordagens.
} 
(oriunda de Mestriner, cuja abordagem metodológica é voltada para o desenvolvimento de embalagens).

Figura 8 - Macroestruturas, com base em vários autores

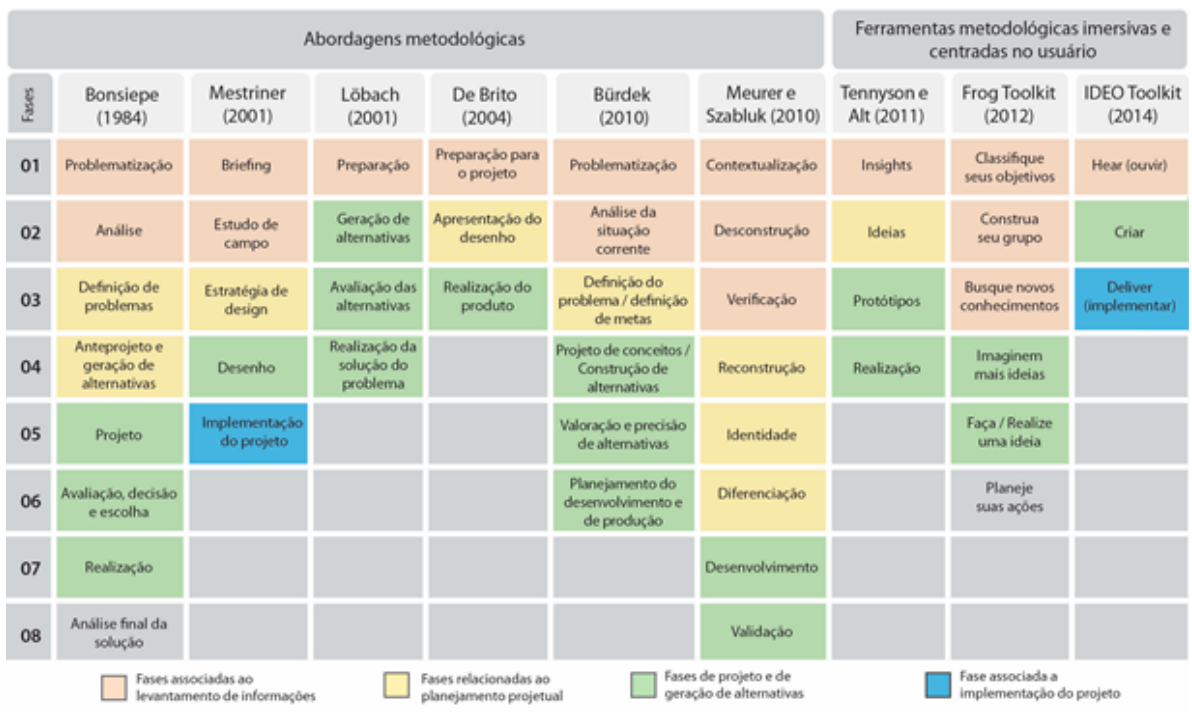

Fonte: arquivo pessoal

Ressalta-se que há uma grande variação quanto ao número de fases sugeridas por cada autor, o que leva à inferência que, em maior ou menor grau, essas fases são desdobradas em microestruturas. Percebe-se, ainda, que algumas fases, apresentadas pelos autores, podem ser incluídas com procedimentos associados a etapas das microestruturas. Essa análise comparativa originou uma síntese, uma formulação de uma macroestrutura própria para este projeto, possibilitando a inclusão de etapas cujos procedimentos estão associados a relações de uso, design da informação e sustentabilidade.

Optou-se pelas fases 'Preparação' (Lobach e De Brito),'Estratégia de Design' (Mestriner), 'Projeto' (Bonsiepe e Burdek), 'Refinamento e Finalização' (Mestriner). Essas fases têm cadência lógica, sugerem 
uma abordagem progressiva e, ao mesmo tempo, possibilitam seu desdobramento em microestruturas cuja seleção de ferramentas possibilita mais flexibilidade. Paralelamente são nomenclaturas próximas ao cotidiano profissional do autor do relatório que atua na área de embalagens, possibilitando uma integração entre sua prática e este estudo técnico-científico. Ao associar essas análises aos objetivos deste projeto, configurou-se a macroestrutura apresentada na Figura 9:

Figura 9 - Caracterização da macroestrutura

\begin{tabular}{|c|c|c|}
\hline $\begin{array}{l}\text { Fases } \\
\text { macro }\end{array}$ & Nomenclatura & Caracteristica \\
\hline 01 & Preparação & $\begin{array}{l}\text { Esta fase engloba as etapas de Diagnóstico e de Análise de Embalagens } \\
\text { Considerando Relaçóes de Uso, Design da Informaçáo e } \\
\text { Sustentabilidade. Para a nomeação foram utilizados os referenciais de } \\
\text { Löbach (2001) e De Brito (2004); com conceitos de Bonsiepe (1984), } \\
\text { Mestriner (2001), Bürdek (2010), Meurer e Szabluk (2010) e Tennyson e Alt } \\
\text { (2011). Foram utilizadas também técnicas e ferramentas utilizadas por } \\
\text { Frog Toolkit e IDEO ToolKit. }\end{array}$ \\
\hline 02 & $\begin{array}{l}\text { Estratégia de } \\
\text { Design }\end{array}$ & $\begin{array}{l}\text { Esta fase engloba as etapas de Estruturação do Problema, Definição e } \\
\text { Hierarquizaçáo dos Requisitos, Modelagem Verbal e Visual do Conceito e } \\
\text { é feito a escolha de um representante de cada linha de produto para a } \\
\text { aplicaçăo do conceito. Para a nomeaçáo é utilizado como referencial a } \\
\text { classificação de Mestriner (2001), sintetizando as fases de definiçăo do } \\
\text { problema e criaçăo de conceito, dos autores Bonsiepe (1984), De Brito } \\
\text { (2004), Bürdek (2010), Meurer e Szabluk (2010) e Tennysone Alt (2011) }\end{array}$ \\
\hline 03 & Projeto & $\begin{array}{l}\text { Esta fase engloba as etapas de Processo de Criação e Desenvolvimento, } \\
\text { Modelagem Fisica das Embalagens para Avaliaçáo e Refinamento e } \\
\text { Validação das Alternativas. Para a nomenclatura é utilizada a classificação } \\
\text { de Bonsiepe (1984), agregando etapas utilizadas por Mestriner (2001), } \\
\text { Löbach (2001), De Brito (2004), Bürdek (2010) e Tennyson e Alt (2011). } \\
\text { Foram aplicadas ainda técnicas utilizadas pelas ferramentas Frog Toolkit } \\
\text { e IDEO ToolKit. }\end{array}$ \\
\hline 04 & $\begin{array}{l}\text { Refinamento } \\
\text { e finalização }\end{array}$ & $\begin{array}{l}\text { Esta fase engloba as etapas de Revisão das Alternativas Finais e de Desdo- } \\
\text { bramentos Projetuais. Como referenciais foram utilizados os métodos } \\
\text { de Mestriner (2001) e da ferramenta IDEO ToolKit. }\end{array}$ \\
\hline
\end{tabular}

Fonte: arquivo pessoal 
Embora não se reconheça, na macroestrutura apresentada na Figura 9, nenhuma fase associada à sustentabilidade, ao Design da Informação ou às relações de uso, as etapas que compõem as microestruturas (detalhadas no próximo tópico) absorveram técnicas e procedimentos com esse enfoque.

\section{MICROESTRUTURA}

Com as macroestruturas definidas, passou-se a delinear as etapas microestruturais de cada fase.

A fase da Preparação é composta por duas microestruturas: Diagnóstico e Análise de Embalagens Considerando Relações de Uso, Design da Informação e Sustentabilidade. A etapa do Diagnóstico inclui o levantamento de informações sobre os produtos Itálica, o estudo do ciclo de vida dos produtos e embalagens da indústria Itálica, o levantamento de necessidades de design com o cliente, a identificação das categorias de usuários, a experiência preliminar de uso dos produtos pelos autores do estudo, a condução de experiências de uso dos produtos com diferentes perfis de usuários, a identificação das percepções dos usuários selecionados para a experiência de uso e a observação da rotina de atividades do usuário interno/funcionário da indústria Itálica. A etapa da Análise de Embalagens considerando Relações de Uso, Design da Informação e Sustentabilidade engloba análises de embalagens de alimentos congelados artesanais, de embalagens de alimentos congelados industrializados, de embalagens com soluções relevantes e de embalagens dos produtos Itálica.

A fase da Estratégia de Design é composta pelas microestruturas estruturação do problema, definição e hierarquização dos requisitos, modelagem verbal do conceito, modelagem visual do conceito 
e escolha de um representante de cada linha de produto para a aplicação do conceito. Na etapa da Estruturação do Problema realizase uma síntese das informações obtidas nas análises anteriores e o problema é redefinido evidenciando requisitos a serem atendidos nas novas embalagens durante a etapa de desenvolvimento, para então na etapa seguinte ocorrer a Definição e Hierarquização dos Requisitos. Na sequência estão situadas as etapas Modelagem Verbal do Conceito e Modelagem Visual do Conceito, para então ocorrer a etapa de Escolha de um Representante de cada linha de Produto para a Aplicação do Conceito gerado.

A fase de Projeto inicia com a etapa de Processo de Criação e Desenvolvimento, na qual estão incluídos procedimentos como processo de criação e desenvolvimento da embalagem física, avaliação e escolha da alternativa das embalagens físicas para as três linhas de produtos, desenvolvimento do projeto de design gráfico e design da informação das três linhas de produtos Itálica. A próxima etapa dessa fase é Modelagem Física das Embalagens para Avaliação e Refinamento constituída por: prototipagem das alternativas finais (testes e modelos de baixa complexidade), refinamento do design gráfico e finalização da alternativa das embalagens propostas para as três linhas de produtos Itálica. Essa fase finaliza com a etapa Validação das Alternativas, constituída por processo de validação com os participantes da experiência de uso das embalagens e processo de validação da solução com o cliente.

A fase de Refinamento e Finalização abrange as etapas microestruturais Revisão das Alternativas Finais e Desdobramentos Projetuais. Na etapa inicial é realizada a revisão das alternativas finais, em que são feitos ajustes e adequações (caso sejam necessários) resultantes da fase anterior. Após essa etapa são realizados os desdobramentos projetuais, em que são sugeridas e discutidas as 
possibilidades futuras em relação às propostas desenvolvidas no projeto.

\section{DESENVOLVIMENTO DA EMBALAGEM}

Após a definição das alternativas, partiu-se para o desenvolvimento do layout dos rótulos das embalagens, definindo cores e elementos visuais do representante de cada linha de embalagem. Nesse momento, além dos requisitos já trabalhados na geração de alternativas, foram inseridos os requisitos legais e de posicionamento da empresa.

Para o desenvolvimento e definição do projeto gráfico dos produtos Itálica, foi escolhida a embalagem da linha Direto ao Forno, que constituiu-se como referência para a aplicação em todas as linhas de produtos Itálica, dentro das suas adequações.

O processo criativo teve início com a definição dos temas centrais Artesanal, Alimento Saudável e Itália, e a partir desses temas foram criadas paletas de cores para que posteriormente fosse definido o padrão cromático do projeto. A Figura 10 apresenta as paletas criadas.

Figura 10 - Paleta de cores por temas

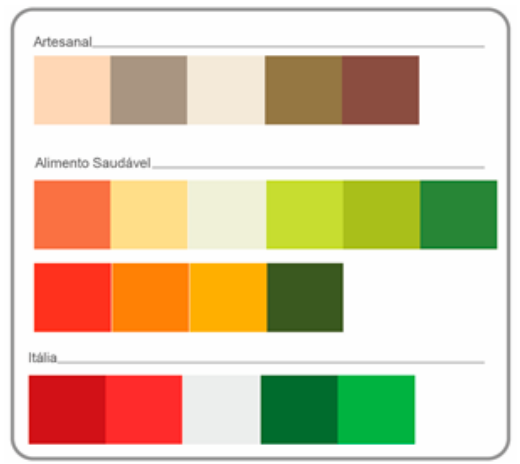

Fonte: arquivo pessoal 
Com as possíveis cores definidas, conforme figura 11 , foram realizados testes cromáticos para definir a combinação de cores utilizadas.

Figura 11 - Definição das cores

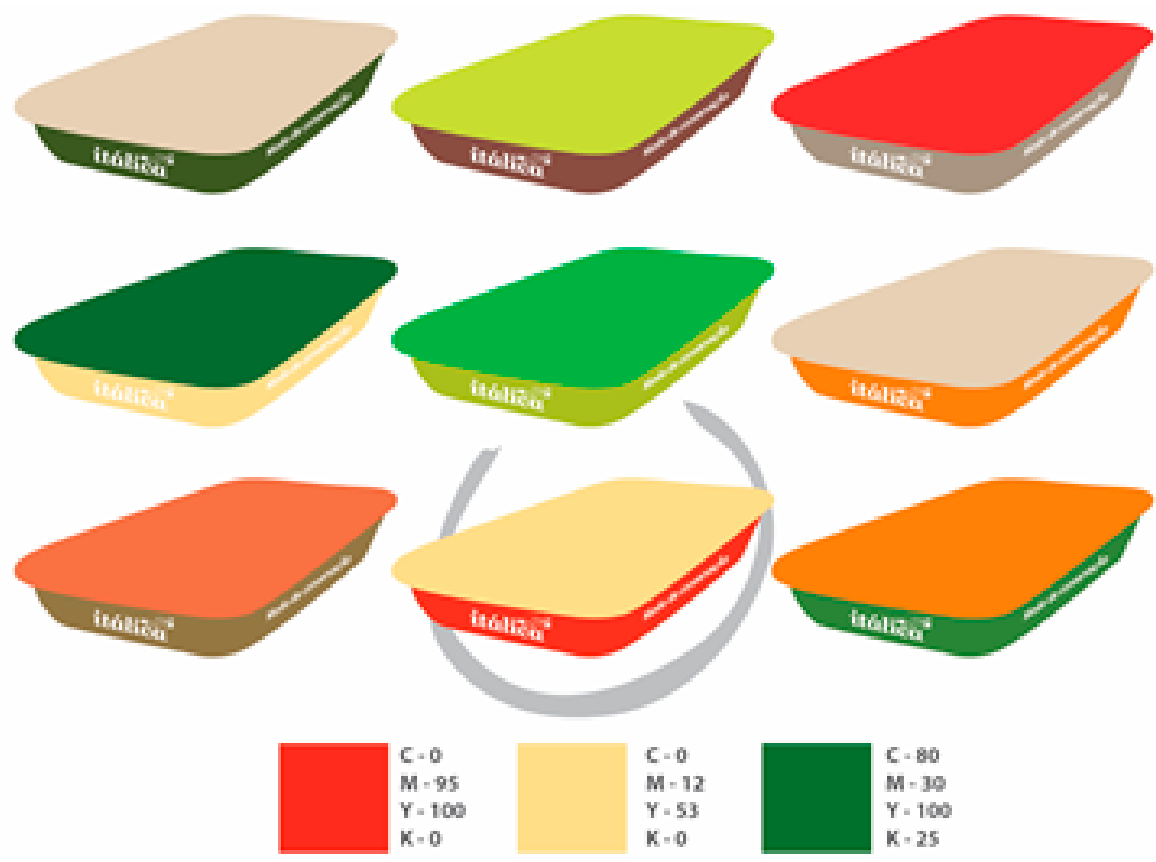

Fonte: arquivo pessoal

Considerando os padrões cromáticos observados em produtos concorrentes e objetivando criar uma combinação que desperte a atenção no ponto de venda, represente o conceito de produto artesanal e mantenha um referencial de reconhecimento da identidade visual atual da Itálica (cor vermelha), foi escolhida a combinação cromática destacada na Figura 11, em que definiu-se uma cor forte para a base (vermelho) e uma cor em tons pastéis para a tampa, associada ao verde que remete a um produto saudável e artesanal. 
Como definido nos requisitos, as embalagens compostas por embalagem termoformada serão impressas em uma cor, para esse caso a cor vermelha apresentada na Figura 11 com código.

Após realizado o estudo de cores, foi feita a estrutura informacional da embalagem, em que foi definido o posicionamento dos elementos gráficos que compõem a embalagem (Figura 12).

Figura 12 - Estrutura informacional da embalagem
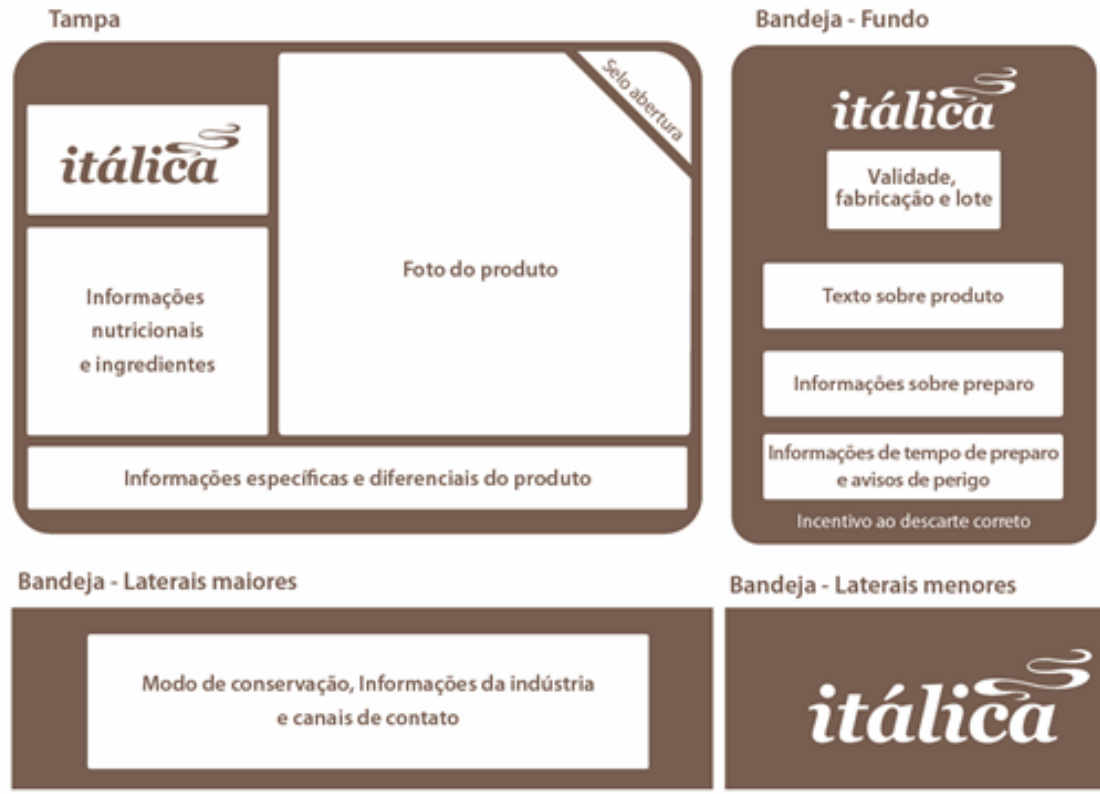

Bandeja - Laterais menores

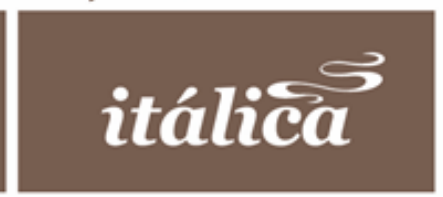

Fonte: arquivo pessoal

A fim de testar a aplicação da nova proposta de design gráfico, foi realizado uma prototipagem rápida em papel da embalagem da linha Direto ao Forno (Figura 13). 
Figura 13 - Prototipagem do layout da linha Direto ao Forno

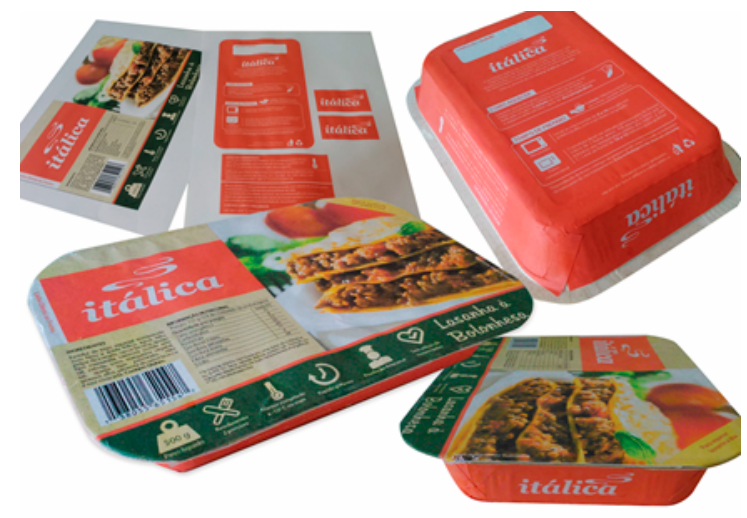

Fonte: arquivo pessoal

EsSa prototipagem teve a função de testar e ajustar a disposição dos elementos e a legibilidade dos textos. Após os ajustes realizados, conclui-se a etapa de criação, sendo definido a nova proposta de design gráfico geral dos produtos Itálica, que será aplicada às demais linhas. Por fim, com o objetivo de representar de forma mais próxima do real, foram gerados simulações de alta definição das alternativas finais. A Figura 14 apresenta a simulação da vista superior (tampa em perspectiva) da linha Direto ao Forno.

Figura 14 - Simulação da tampa da linha Direto ao Forno

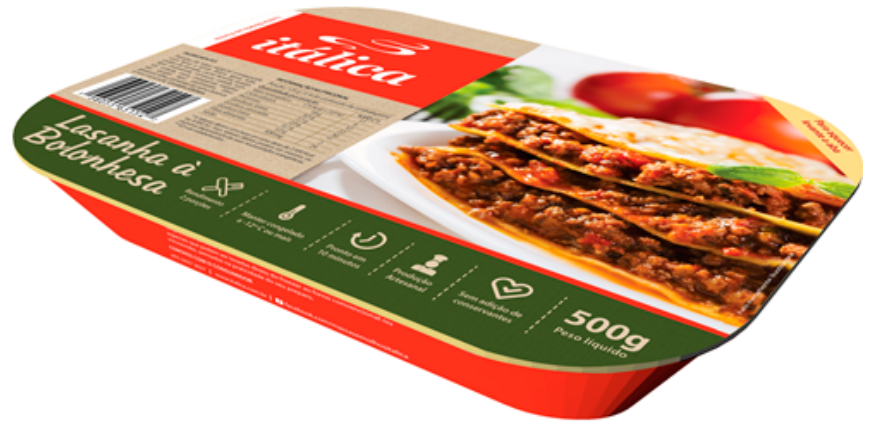

Fonte: arquivo pessoal 
A figura 15 apresenta a simulação da bandeja em perspectiva da linha Direto ao Forno.

Figura 15 - Simulação da bandeja da linha Direto ao Forno

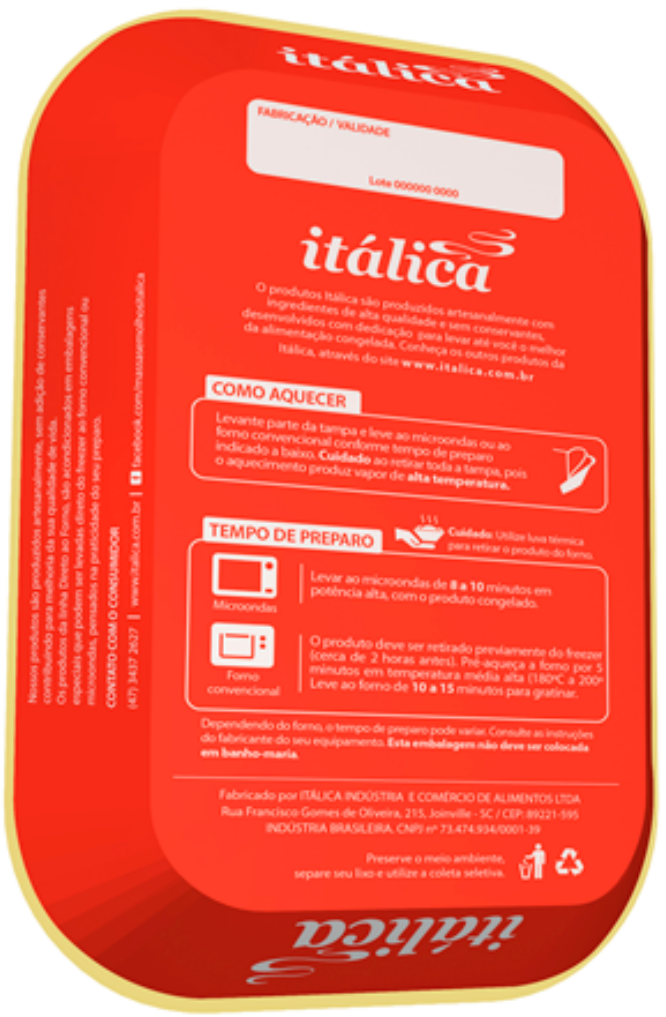

Fonte: arquivo pessoal

A validação com usuários se deu com os oito participantes da experiência de uso das embalagens Itálica. Por conta da dificuldade de reunir os oito participantes, as avaliações de cinco dos participantes se deram em dois encontros realizados no dia 18 e 20 de fevereiro de 2015, e o restante foi realizado via e-mail, sendo enviado um resumo das etapas do projeto e as imagens e layouts gerados da nova proposta. A Figura 16, a seguir, apresenta os encontros realizados. 
Figura 16 - Validação das alternativas com usuários

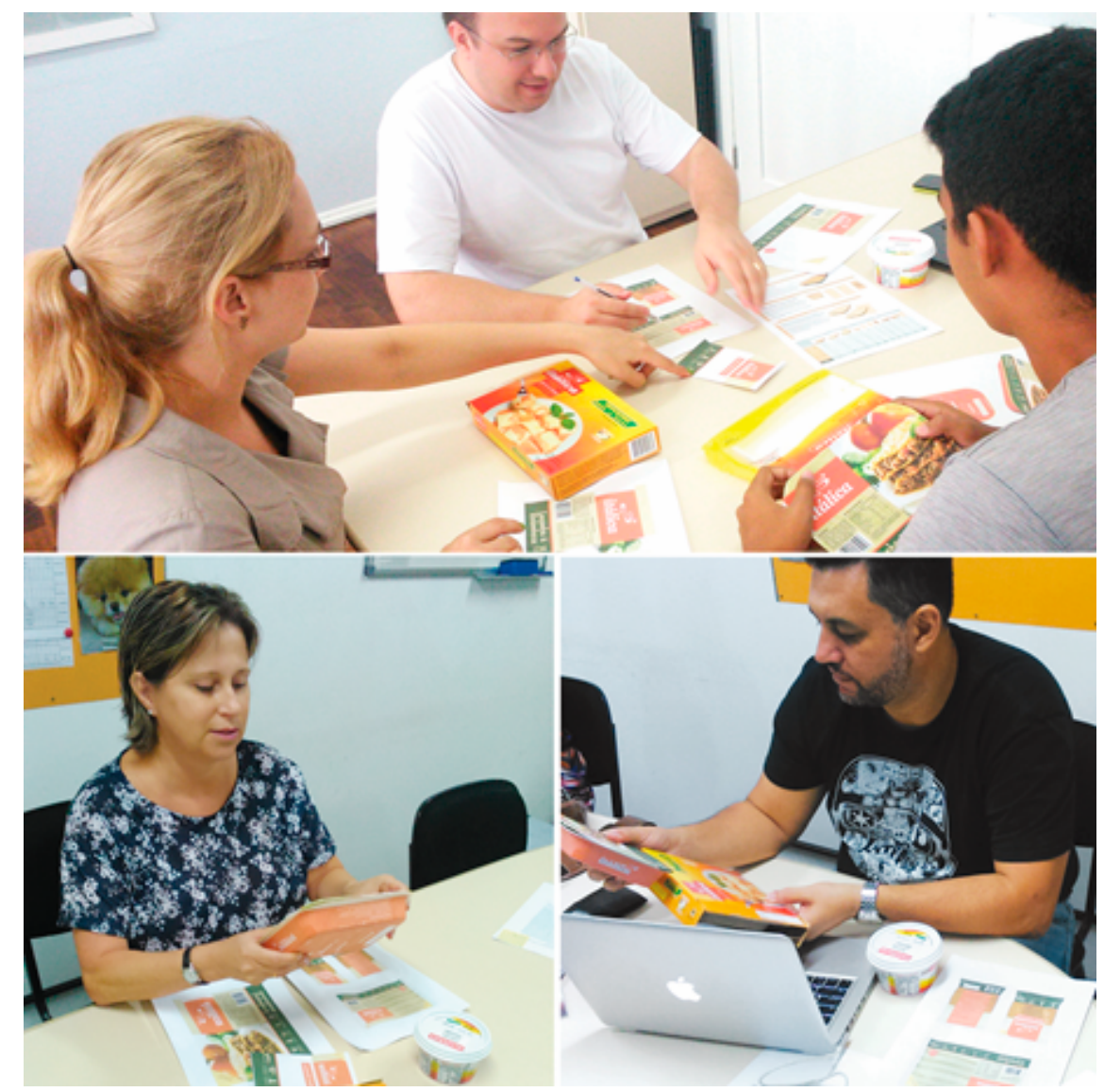

Fonte: arquivo pessoal

\section{CONSIDERAÇOES FINAIS}

As mudanças propostas para as embalagens, além de possibilitarem benefícios para os usuários, poderão gerar uma melhoria no processo interno da indústria itálica no manuseio das embalagens, ganhando tempo ao eliminar as etapas de montagem e fechamento de caixas da linha Direto ao Forno, retirando a 
embalagem secundária; e reduzindo também as etapas de selamento das embalagens da linha Molhos Prontos, ao reduzir o pote (que contém lacre externo e interno) para a embalagem em forma de saco plástico.

Em relação à sustentabilidade, a nova proposta prioriza amenizar a quantidade de resíduos provenientes do uso das embalagens. Sendo que em determinada situação propõe a redução das embalagens excedentes (linha Direto ao Forno), atribui uma nova função para embalagens que têm apenas a função de conter o alimento, prolongando a sua vida útil (bandeja da linha Molho e Forno), e reduz consideravelmente os resíduos plásticos atuais (linha Molho e Forno).

A viabilidade de implementação da proposta foi considerada durante todo o processo de desenvolvimento, entretanto as mudanças propostas devem estar de acordo com o relato e as sugestões feitas pela indústria Itálica, sendo necessário também um estudo mais aprofundado juntamente com os fornecedores, para assegurar que esta nova implementação seja adequada também em termos técnicos e de materiais.

\section{AGRADECIMENTOS}

Agradecimentos ao Programa Institucional de Bolsas de Pós-graduação (PIBPG), ao Fundo de Apoio à Pesquisa (FAP) e à Universidade da Região de Joinville (UNIVILLE) 


\section{REFERÊNCIAS}

. Collective Action Toolkit. Disponível em: <www.frogdesign. com/cat>. Acesso em: 6 mai. 2014.

FROG DESIGN. Disponível em: <www.frogdesign.com>. Acesso em: 5 mai. 2014.

IDEO. Disponível em: <www.ideo.com>. Acesso em: 5 mai. 2014.

IDEO. Human Centered Design Toolkit. Disponível em: <www.ideo. com/work/human-centered-design-toolkit>. Acesso em: 6 mai. 2014.

MIJKSENAAR, P.;WESTENDORP, P. Open Here: the art of instructional design. London: Thames \& Hudson,1999, p. 144.

MORAES, A. M.; MONT'ALVÃO, C. Ergonomia: conceitos e aplicações. Rio de Janeiro: 2AB, 2009, p. 232.

NORMAN, D. O Design do dia a dia. Rio de Janeiro: Rocco, 2006, p. 71.

PREECE, J.; ROGERS, Y.; SHARP, H. Design de interação: além da interação humano-computador. Porto Alegre: Bookman, 2013, p. 600.

SANDERS E. From User-Centered to Participatory Design Approaches. In: Design and the Social Sciences. J.Frascara (Ed.), Taylor \& Francis Books Limited, 2002. Disponível em: http://maketools.com/articlespapers/FromUsercenteredtoParticipatory_Sanders_\%2002.pdf. Acessado em: 15 jun. 2014

TENNYSON, P.; ALT, L. Design Thinking Brasil: empatia, colaboração e experimentação para pessoas, negócios e sociedade. Rio de Janeiro: Elsevier, 2011, p. 230. 



\section{A imersão em uma indústria joinvilense possibilitando um diagnóstico para a busca de uma nova atuação de mercado ${ }^{1}$}

Larissa Angeoleti Schulenburg (Currículo Lattes) Victor Rafael Laurenciano Aguiar (Currículo Lattes)

\section{INTRODUÇÃO}

Da constante busca pela inovação nas organizações emergem novas atuações que vão além dos limites tradicionalmente estabelecidos em determinados campos disciplinares da gestão. Nesse sentido, o design vem se consolidando com novas práticas e atuações mercadológicas. Observa-se que um projeto de design, atualmente, não é mais considerado apenas como um resultado que contemple soluções práticas, estéticas e funcionais. Com a

\footnotetext{
${ }^{1} \mathrm{O}$ artigo apresentado neste capítulo foi publicado no congresso P\&D 2016, o qual antecedeu a organização deste livro.
} 
atual discussão das práticas do Design como um serviço, salientase a preocupação em propor soluções para a indústria. Pode-se considerar ainda, que o design como um campo exploratório de atuações bem-sucedidas, pode enriquecer o modelo de gestão que se tinha concebido previamente e tradicionalmente em áreas administrativas.

O presente estudo apresenta parte de uma pesquisa realizada para a empresa Grampel em parceria com o Mestrado Profissional em Design daUniville, comointenção de contribuir com a competitividade e produtividade da referida indústria joinvilense. A indústria em questão atua no ramo de metalomecânico, realizando prestação de serviços em soluções de cortes a laser. Após contato inicial com a organização, percebeu-se uma interessante oportunidade para o designer operar em parceria com a indústria.

\section{A GRAMPEL}

A Grampel é uma indústria situada em Joinville/SC, prestadora de serviços em soluções de Corte a Laser. Focada no ramo metalomecânico, a Grampel atua no mercado desde 1982, inicialmente em um galpão alugado e tendo como razão social Funilaria XV Ltda. Em 1991 passou a ter sede própria com 300 m² de área construída e houve a troca da razão social para a atual marca Grampel Ind. e Com. Ltda. Com o aumento de clientes, em 1998 a Grampel adquiriu, com recursos próprios, um terreno de $7.000 \mathrm{~m}^{2}$, dos quais $1.100 \mathrm{~m}^{2}$ são de área construída.

O início da pesquisa deu-se após convite do diretor da indústria para uma visita técnica de observação seguida de uma entrevista semiestruturada para fins de diagnóstico inicial. O diretor procurou o programa de Pós-graduação em Design da Univille com a pretensão 
de criar produtos próprios, além de buscar alternativas viáveis para sua atual capacidade produtiva. Após o convite, a visita de campo ocorreu em julho de 2013, possibilitando um diagnóstico inicial e coleta de algumas análises e levantamentos importantes para o desenvolvimento da pesquisa, levando em consideração suas expectativas, interesses e oportunidades aparentes.

Ainda nessa visita, percebeu-se que a indústria gera um alto volume de resíduo, o qual impacta a necessidade de pesquisas que possibilitem minimizar seus efeitos no meio social e ambiental, equilibrando também fatores econômicos. A empresa atualmente descarta uma caçamba de resíduos por semana, o que resulta em $28 \mathrm{~m}^{3}$ de resíduos por mês. A Grampel utiliza, como matérias-primas principais, o alumínio e o aço, que respectivamente rendem com o descarte o valor de $R \$ 2,90$ e $R \$ 2,10$ por quilograma de sucata. A fim de equilibrar objetivos econômicos e mercadológicos com valores ambientais e sociais, a indústria considerou que os resíduos metálicos poderiam oportunizar, por meio do design, soluções inovadoras de produtos.

Percebeu-se o pouco conhecimento na área do design, motivo que poderia causar frustações futuramente. Nesse sentido foi colocado pelaos pesquisadores que para lançar produtos é necessário considerar o planejamento e a gestão como pontos indispensáveis para o sucesso. Para tanto, seria indispensável gerir um processo coeso e estratégico que iria além do desenvolvimento e criação de uma linha de produtos. Alguns aspectos foram questionados, tais como: comercialização, marca, posicionamento, entre outros fatores necessários para atender ao mercado. Sendo esclarecido pelos pesquisadores que o papel do designer no cenário atual, de novas práticas de atuação, é ser um profissional capaz de executar um estudo de serviços na área da gestão, com ferramentas e metodologias que 
contribuam para viabilizar tal projeto com eficiência. A intenção foi demonstrar que apenas criar bons produtos não é segurança de ter um mercado promissor, conforme aponta Mozota (2011, p. 145) ao afirmar que "[...] um bom produto não é suficiente para o sucesso da inovação: estudos anteriores enfatizam a importância da gestão no desempenho da inovação."

Para que a ideia inicial da Grampel no desenvolvimento de produtos obtenha o sucesso desejado, chegou-se à conclusão que a pesquisa precisava contribuir de forma mercadológica para a indústria. Para planejar este lançamento de produtos, faz-se necessário diagnosticar a atual situação e posicionamento da indústria e dessa forma poder agir estrategicamente com ações futuras. De maneira a apontar um lançamento de produto com um planejamento mais criterioso, fica evidente o diagnóstico estratégico como uma questão de embasamento para gerir e organizar essa intenção de desenvolvimento de produtos. Nesse sentido, esta pesquisa visa contribuir para o incremento da ciência e da prática no que diz respeito às áreas de Design, gestão e inovação na indústria.

O alinhamento estratégico da gestão do design para a atuação da indústria Grampel viabiliza uma oportunidade atrativa de mercado, podendo ainda gerar uma vantagem competitiva com os recursos e capacidade produtiva que a empresa já possui.

\section{DIAGNÓSTICO ESTRATÉGICO}

O presente capítulo relata a fase de imersão, proposta para o diagnóstico estratégico na Grampel. Esta fase de imersão desmembrou-se em análise interna e externa, as análises foram realizadas utilizando-se da ferramenta SWOT, da qual resulta um quadro direto e objetivo das ameaças e oportunidades, forças e 
fraquezas, podendo, assim, futuramente direcionar as definições estratégicas.

A análise interna é um dos elementos que fornece subsídios para criação do quadro SWOT. Para tanto, apresentam-se os pontos fortes e pontos fracos coletados e identificados internamente, desde a etapa inicial da pesquisa e até o aprofundamento dos estudos.

No modelo SWOT identificam-se como pontos fortes na análise interna os fatores e diferenciais da Grampel que podem significar vantagem competitiva. Como pontos fracos relacionam-se algumas deficiências e limitações que possam intervir no desempenho de mercado e no cenário em que a Grampel poderá atuar.

Nesse viés, consideram-se as ações compatíveis com uma possível atuação mercadológica para o desenvolvimento de produtos direcionados ao novo mercado de atuação, a fim de estipular metas para o andamento das fases seguintes. Os métodos utilizados para a análise interna no decorrer da pesquisa foram relatos, observações e entrevistas, dos quais apresentam-se os resultados coletados.

A análise contemplou tópicos apontados por Aarker (2001), Mozota (2011), Martins e Merino (2011), autores que discorrem sobre os possíveis requisitos para diagnóstico estratégico organizacional. Tendo em vista os assuntos pertinentes, elaborou-se o Quadro $1 \mathrm{com}$ os requisitos principais de análise interna realizados na Grampel. 
Quadro 1 - Requisitos analisados internamente

\begin{tabular}{l|l}
\hline REQUISITOS & $\begin{array}{l}\text { FOCOS DA ANÁLLSE } \\
\text { De que maneira a indústria contempla ou imagina } \\
\text { como ferramenta? }\end{array}$ \\
\hline $\begin{array}{l}\text { Design } \\
\text { Branding / Posicionamento }\end{array}$ & Como se planeja o posicionamento de marca? \\
\hline Máquinas & Quais equipamentos e Instalaçōes? \\
\hline Materiais & $\begin{array}{l}\text { Qual seria a capacititaçãado e desenvolvimento do material a ser explorado? } \\
\text { dos profissionais? }\end{array}$ \\
\hline Mão de Obra & $\begin{array}{l}\text { Como se fomentará a sustentabilidade ecônomica } \\
\text { e ambiental? }\end{array}$ \\
\hline Meio Ambiente & Como gerir a nova atuação? \\
\hline $\begin{array}{l}\text { Gerenciamento e Lançamento } \\
\text { de Produtos }\end{array}$ & Como lançar campanha e vender produtos? \\
\hline Marketing &
\end{tabular}

Fonte: primária (2014)

No requisito Design, foram interpretados os dados coletados por meio de observações durante visitas na empresa e complementado com entrevista por meio de um questionário semiestruturado. Destaca-se na entrevista um ponto no qual o diretor da empresa relata que a Grampel não possui um produto próprio e como os serviços prestados não são seriados, a indústria fica limitada a trabalhar com um grupo específico de clientes. Devido à realização de compras esporádicas e não seriadas desses clientes, foi mencionado pelo entrevistado que há períodos em que os profissionais e maquinários apresentam tempo ocioso na produção. 
O diretor em sua fala também demonstrou interesse e possibilidade de criar um centro de design dentro da sua indústria. O entrevistado demonstra pouco conhecimento sobre design e as habilidades do profissional dessa área, porém interpreta como uma profissão indispensável no desenvolvimento de produtos e como fator de grande impacto mercadológico perante a concorrência. Dessa forma, percebe-se ainda um fator que o instigou investir em design, citando a concorrência desleal dos produtos importados da China e afirmando o "design" como um aspecto de diferenciação de produtos com valor agregado. Quando questionado sobre branding, ainda conforme entrevista com o diretor, considerando a possibilidade de atuação de um novo mercado, o gestor da Grampel discorre sobre inúmeras possibilidades de desenvolvimento de produtos, comparando marcas do segmento decorativo do mercado da região. Nesse cenário ele afirma a necessidade de realmente posicionar a Grampel em um novo mercado com uma nova marca. Quanto aos materiais foi declarado pelo gestor que o aço e alumínio, materiais utilizados em seus processos, fazem parte de sua maior motivação para a criação da nova atuação mercadológica. Esses materiais são vistos como nobres em diversos produtos no mercado de segmentos decorativos, demonstrando ser o campo de atuação ideal imaginado por ele. Partindo da premissa de que se tem o material a ser explorado, iniciou-se a busca por informações referentes aos maquinários, que auxiliou no levantamento de dados.

Com soluções de cortes a laser de alta tecnologia, a Grampel atende a toda a região Sul do país com serviços de corte, dobra e solda de chapas planas de aço com processos metalomecânicos e maquinários específicos de alta performance. Os materiais que a Grampel utiliza nos maquinários apresentados no Quadro 1 são: aço-carbono, cortado na espessura de até 15,87 mm, aço inox, com 
espessura de até $6,35 \mathrm{~mm}$, e o alumínio, espessura de até $4 \mathrm{~mm}$. Para que se possa fabricar e entregar as peças totalmente prontas para o cliente, a Grampel executa serviços além de corte a laser, como também soldas, dobras e furação, considerando essas operações como refinamento e acabamento de algumas peças.

Como apoio na realização dos seus serviços, a indústria contempla a mão de obra com um setor de engenharia de processo no qual emprega 4 colaboradores com formação na área de projetos metalomecânicos. Esse setor realiza projetos com softwares e sistema de apoio. Os softwares utilizados nos processos e alinhados na comunicação com os máquinarios são: SolidWorks, Lantek e Autocad. O SolidWorks e Autocad são softwares que desenvolvem projeto de peças tridimensionais e bidimensionais, já o Lantek é utilizado na programação, gerenciamento e automatização de máquinas, distribuindo em linha de produção as peças projetadas.

Considerando que se trata de uma empresa prestadora de serviços e que não tem produtos próprios, a empresa não investe significativamente em marketing, possui o quadro de vendedores atuando na prospecção constante para fidelizar clientes. Em paralelo utiliza uma rede social para divulgar e manter um contato de relacionamento e mantém um site para formulário e pedidos eletrônicos.

Quanto à questão ambiental, o gestor relatou sua preocupação com o grande acúmulo de descarte de materiais. Por se enquadrar em uma indústria metalúrgica, as atividades realizadas na Grampel precisam estar em consonância com a lei ambiental exigida para as atividades da indústria. A Licença Ambiental de Operação (LAO) autoriza e permite o funcionamento de equipamentos de atividades e serviços e dá continuidade ao licenciamento efetuado. Por isso a LAO possui prazo de validade, pois acompanha por meio de vistorias se a 
indústria atende às restrições e contribuições ambientais. Os resíduos industriais da Grampel são recolhidos por empresas certificadas, a empresa vende a sucata mediante a emissão de nota fiscal da empresa compradora, para assim comprovar o correto recolhimento do material descartado. Esses resíduos apresentam formatos, peso e espessuras variadas. Essa variação é devido à prestação de serviços de acordo com a demanda de pedidos específicos. Os tipos de descarte não têm certa rotina de pedidos, em média recebe-se um pedido a cada trimestre para a prestação desse serviço, resultando em cerca de 40 peças ao fim de cada trimestre.

Após a observação interna na Grampel inicia-se a compilação dos pontos fortes e fracos detectados. Para ilustrar em tópicos, apresenta-se o Quadro 2.

Quadro 2 - Pontos fortes e pontos fracos

\begin{tabular}{l|l}
\hline PONTOS FORTES & PONTOS FRACOS \\
\hline $\begin{array}{l}\text { Apresenta Recursos Industriais e } \\
\text { Financeiros Adequados }\end{array}$ & $\begin{array}{l}\text { Inabilidades Técnicas de Produtos Fora do } \\
\text { Contexto Metal Mecânico }\end{array}$ \\
\hline $\begin{array}{l}\text { Aspira Desenvolver e Investir em } \\
\text { Nova Atuação Mercadológica }\end{array}$ & $\begin{array}{l}\text { Falta de Definições Estratégicas de } \\
\text { Design e Branding }\end{array}$ \\
\hline Considera Branding e Design & Baixo Investimento em Design e \\
como Fatores Importantes & Pesquisas de Mercado \\
\hline Conhecimento Amplo da & Falta de Designers para \\
Matéria Prima & Desenvolvimento de Produtos \\
\hline Possibilidade de Planejamento & Falta de Posicionamento de Mercado e \\
Sustentável pela Sucata e Resíduos & Foco no Segmento de Produto \\
\hline Possibilidade na Competitividade de & Impossibilidade de Divulgação de \\
Produtos pelo Custo & Processos e Serviços em Profundidade \\
& para Terceiros (parcerias)
\end{tabular}

Fonte: primária (2014) 
Os pontos fortes e fracos relacionados no Quadro 2 foram pautados por meio das visitas, observações e relatos coletados de acordo com os requisitos estabelecidos para análise interna e apresentado no Quadro 1. Assim sendo, os focos de análise como design, branding/posicionamento, materiais, gerenciamento e lançamento de produtos, mão de obra, máquinas, marketing, sustentabilidade foram contemplados dentro da relação dos pontos fortes e pontos fracos. Diante disto, foi necessário obter um levantamento claro e objetivo de requisitos e restrições no ponto de vista projetual, considerando o material a ser trabalhado.

Foram verificadas as características referentes ao material de descarte e observou-se os pontos que possibilitam fomentar uma possível organização para o desenvolvimento de produtos com foco na gestão estratégica do Design. Para tanto foi elaborado uma comparação considerando as duas opções do retalho de chapas, conforme ilustrado no Quadro 3.

Quadro 3 - Características do retalho

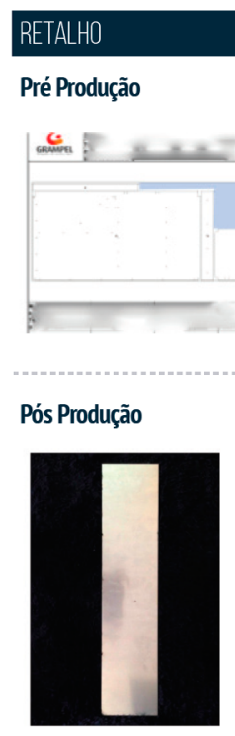

\section{CARACTERISTICAS}

No setor de engenharia de processos é realizado o projeto para maior aproveitamento da chapa, entretanto ainda resta sobra de material que,se não utilizado, será descartado.

Fonte: primária (2014) 
No quadro 3 foi ilustrado o retalho da pré-produção e da pósprodução, concluindo-se que a pré-produção será a melhor opção passível de intervenção para desenvolvimento de produtos. Para estipular as características quanto ao material e ao processo que poderá ser utilizado na nova atuação mercadológica, considera-se o fator importante do aproveitamento de retalhos da pré-produção dos pedidos que são efetuados recorrentemente à Grampel. Essa forma de aproveitamento evita o retalho, já que a empresa inclui o projeto de novos produtos e/ou suas partes na produção articulada com os pedidos, gerando assim uma competitividade mercadológica pelo melhor aproveitamento da chapa do alumínio. As peças de retalhos pós-produção são descartes do material provenientes de pedidos e os quais não se pôde integrar os espaços vagos para aproveitamento na linha de produção, visto apresentar um custo elevado por terem baixas dimensões. Sendo assim, indica-se o aproveitamento melhor da chapa na própria linha de produção (pré-produção).

Face ao exposto, as características do material e processos partem do princípio de estipular um direcionamento para a presente pesquisa obter foco em determinado campo possível dentro da viabilidade da Grampel. Todavia, têm-se as peças de retalho relacionadas e a necessidade de implementar as características projetuais para o desenvolvimento de produtos com foco na gestão estratégica do design. Por isso, definiram-se particularidades do material e processos para projeto de produtos com base nos planos de cortes do cliente que demanda maior volume de pedidos e descartes. Pela análise de pedidos desse cliente, constatou-se uma demanda significativa de pedidos com retalhos de descarte passíveis de intervenções. Nesse sentido, após a possível criação de produtos e dentro das características e particularidades do material, salientase a possibilidade do produto ser planejado no setor de engenharia 
de processos, considerando o aproveitamento da chapa na linha de produção e evitando o descarte final de retalho. Para tanto, apresentam-se no Quadro 4 as características estipuladas quanto à demanda de material disponível a ser aproveitado na nova gestão proposta.

Quadro 4 - Requisitos e restrições

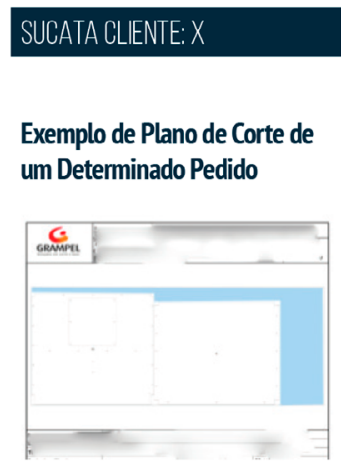

CARACTERISTICAS

- Material:Alumínio

- Dimensões Recorrentes:

$15 \times 40 \mathrm{~cm}-30 \times 30 \mathrm{~cm}-50 \times 30 \mathrm{~cm}$

- Produção Mensal: 80 peças

(para cada dimensão)

- Espessura:1,5mm

- Processos: Corte à laser, dobra e solda.

Fonte: primária (2014)

Diante das características apresentadas no Quadro 4, obtevese um foco direcionado de intervenção para possíveis criações de produtos, contemplando medidas, material, espessura e processos de produção que podem ser utilizados. Como já mencionado, o material foco é o alumínio. Diante da análise dos pedidos rotineiros de um determinado cliente, estipularam-se as áreas livres da chapa de alumínio que podem ser aproveitadas, dessa maneira têm-se as medidas de $15 \times 40 \mathrm{~cm}, 30 \times 30 \mathrm{~cm}, 50 \times 30 \mathrm{~cm}$. Essas medidas são recorrentes nas sobras de chapas de pedidos possuindo uma produção mensal de 80 peças para cada dimensão. Observando variáveis de volume de produção, tem-se a sobra de 240 peças por mês nas três dimensões, podendo ser considerado $24 \mathrm{~m}^{2}$ de área 
de chapa de alumínio por mês para ser trabalhada. A chapa do alumínio para esse caso apresenta a espessura de 1,5 mm e pode ser considerada no processo de corte a laser, dobra e solda.

Tais características apresentadas fomentam uma maneira de esclarecer a real capacidade produtiva, possibilidades e limitações da Grampel para o novo mercado. Desse modo, as informações ordenadas das características podem vir a fazer parte de um possível briefing para o designer de produtos que criará as peças para o novo mercado de atuação. Com isso, tem-se a necessidade de iniciar a pesquisa referente à análise externa e assim direcionar ainda mais o posicionamento e possibilidades de atuação.

A análise externa, dentro da ferramenta SWOT, é responsável por identificar ameaças e oportunidades impostas pelo cenário externo. Permite a organização de ideias a fim de poder tirar proveito de oportunidades apontadas ou precaver-se de possíveis ameaças. Diante das características levantadas na análise interna, considerouse primordial que a análise externa contemplasse produtos com a mesma matéria-prima, ou seja, o alumínio. Dentro desse contexto observaram-se as opções consideradas nos relatos do diretor, direcionando a análise pelo material com pequenas dimensões, processos utilizados de corte a laser, solda e dobra, bem como a espessura definida e os aspectos restritivos da Grampel.

O alumínio é um material reciclável; para fabricação de novas peças e produtos, ele passa por um processo de fundição para gerar o material em estado líquido. Após o estado líquido são realizados procedimentos que podem gerar produtos por meio de moldes ou em chapas para voltar à cadeia produtiva industrial. Por isso esse material é considerado 100\% reciclável. Entretanto, a intenção de utilizar o alumínio no processo de produção da indústria não contempla a fundição do material, e sim o aproveitamento melhor da 
chapa dentro do próprio processo de corte. Todavia, após a criação e comercialização do produto, ele ainda pode voltar à cadeia produtiva sendo descartado e voltando ao processo de reciclagem e fundição descritas.

Diante da intenção de contemplar os requisitos e restrições, temse na análise externa a compilação de alguns produtos dispostos no mercado com a utilização do material foco da pesquisa. Consideramse ainda fatores como montagens e desmontagens de peças, bem como a composição com outros materiais. Dessa forma, podem-se oferecer maiores diferenciações de produtos atribuindo o material de base, o alumínio, em aproveitamento de chapas de retalhos. A possibilidade de aplicar outros materiais que a Grampel não contempla em seus processos possibilita uma maior diferenciação e criatividade, pois o designer terá menos restrições para criar.

Para ilustrar alguns produtos no mercado apresenta-se na Figura 1 um painel semântico com semelhanças de fabricação a partir das características restritivas da Grampel e selecionados conforme definições do material.

Figura 1 - Painel semântico de produtos decorativos de alumínio PAINEL SEMÂNTICO

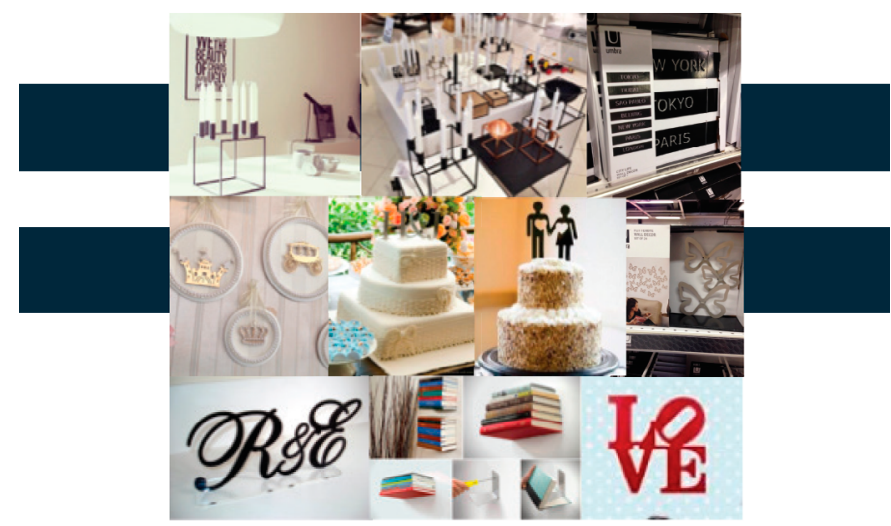

Fonte: primária (2014) 
O painel ilustrado na Figura 1 foi elaborado com registros fotográficos dos pesquisadores e com consultas em sites de busca de imagens como tendências, sendo selecionadas as que condizem com o material alumínio, recortes a laser e peças relativamente pequenas. Diante desse ponto de partida, visualizam-se possíveis atuações para o mercado de produtos em alumínio. Podem-se perceber alguns segmentos de atuação dentro do mercado decorativo como: decoração de parede, decoração com velas, decoração com letras, porta-livros e decoração de bolos de casamentos.

Contudo, percebe-se que o campo da decoração possui variáveis de comercialização, podendo contemplar utensílios, funcionalidade, apelo emocional, entre outros fatores, diversificando segmentos. Ainda nesse contexto, Lobach (2001) também aborda a temática de produtos diferenciados por meio do design e aponta como objetivo buscar diferentes versões de produtos, diferenciando-se sobretudo pelo público-alvo, atendendo a um usuário. "No mundo competitivo, não é lucrativo simplesmente copiar o design alheio. A originalidade das soluções impulsiona os negócios, revertendo beneficamente para quem soube investir nesse nicho" (Nese, 2010, p. 67). Por isso é importante salientar que a busca de imagens realizadas direcionaram uma base de segmento de possível atuação e que a Grampel já havia fabricado alguns produtos do segmento decorativo (apresentados na análise interna), utilizando-se de cópias de concorrentes, não buscando originalidade e valor agregado às peças.

Para possíveis atuações de mercado, atribuindo dados mercadológicos e definição de melhores estratégias no contexto econômico, estima-se o ramo de decoração como muito atrativo e com alto potencial de rentabilidade. Percebe-se ainda que o alumínio é bastante utilizado como material no segmento decorativo, já que o material possibilita o manejo diversificado, durabilidade, resistência 
e rigidez. Ainda nesse contexto, podem-se inserir segmentos mais objetivos, como, coleções personalizadas, temáticas com datas festivas, entre outras opções de criação e desenvolvimento de produtos. Não há impedimento quanto à atuação simultânea nos segmentos decorativos em geral, conforme direcionamento de algumas lojas.

Para análise externa visualizar possíveis concorrentes de atuação, foram selecionadas duas empresas para verificações de suas estratégias. As empresas foram selecionadas por comercializarem peças com os requisitos estabelecidos na pesquisa e produtos relacionados ao painel ilustrado na Figura 11, sendo premissa:material alumínio, corte a laser e pequenas dimensões. Para denominar as empresas em questão, utilizam-se as letras X e Y, dessa forma evita-se a divulgação sem a prévia autorização legal.

A empresa $X$ iniciou suas atividades em Santa Catarina na década de oitenta. Cria, desenvolve e distribui objetos de decoração para todo o Brasil em formato de lojas multimarcas e franquias. Os produtos comercializados são de diversos materiais, além dos artefatos em alumínio, como madeiras, tecidos e plásticos. Salientase que as peças são criadas sugerindo experiências de consumo diferenciadas ao público, celebrando temáticas como família, amigos, lazer, bons momentos e satisfação. Em apenas quatro anos a empresa já havia desenvolvido um sistema de franquias possuindo quinze lojas durante esse período. Atualmente são 145 lojas exclusivas em todo o Brasil, comercializando também em formato de e-commerce com outras marcas não próprias. A equipe contempla 750 profissionais distribuídos em escritórios de franquias, escritório de criação de produtos e centro de distribuição. O crescimento e consolidação da empresa $X$ são atribuídos ao fato de permanecerem com a premissa e 
essência do design, sendo referência em inovação, design e diversão no desenvolvimento de produtos.

A empresa $Y$ assemelha-se à $X$ no que diz respeito à comercialização de produtos com materiais diversos. No segmento decorativo, a empresa $Y$ destaca peças wallart, traduzindo no português literal como arte de parede. Nessa atuação a empresa em questão desenvolve produtos em alumínio e recortes a laser para decoração de paredes. Outras peças de utensílios diários e de cozinha também são encontradas em peças de alumínio, entretanto já possuem características que diferem das necessárias para a Grampel, pois são elaboradas com moldes e derretimento do alumínio, não sendo possível fabricá-las com recortes de chapa, solda e dobra. A empresa $Y$ tem sede em Toronto, onde iniciou as suas atividades há trinta anos. Com exportação para o mundo todo, é referência em produtos com design criativo, possuindo uma equipe interna internacional de criação, pesquisando demandas que permitem avançar uma ampla gama de clientes e culturas.

Conforme Aaker (2001), a análise externa compila elementos externos à organização que são estratégicos e servem como propósitos de verificação de possíveis oportunidades e ameaças em um comparativo para a organização. Dessa forma, elaborou-se um quadro compilando dados, estratégias e fatores-chave, verificouse as duas concorrências apuradas, como também o mercado de atuação do segmento decorativo, conforme ilustrado no Quadro 5. 
Quadro 5 - Quadro da análise externa

\section{ANÁLISE EXTERNA 圆}

ESTRATÉGIAS DA CONCORRÊNCIA

Com base nas Empresas $\mathrm{XeY}$

- Franquias e Lojas Exclusivas

- Venda no Atacado e Varejo

- Venda por E-Commerce

- Lojas próprias e Franqueadas

- Centro de Distribuição de Produtos

- Centro Interno de Design e

Desenvolvimento de Produtos

- Constante Renovação de Produtos

- Coleções Sazonais Temáticas

(de acordo com datas varejistas)

Legenda

Venda de produtos

Desenvolvimento de Produtos

\section{MERCADO}

- Em 2013 os brasileiros gastaram 8\%

a mais em artigos de decoração comparado ao ano de 2012.

- Produtos com apelo emocial e design agregado

- E-commerce como tendência de ferramenta para vendas

- Redes sociais como suporte e marketing

Legenda

Crescimento

- Tendência

$\square$ Fatores Chave para o Sucesso

Fonte: primária (2014)

Diante das estratégias verificadas nas concorrências, conforme Quadro 5, percebeu-se a forte preocupação com design no desenvolvimento de seus produtos e sua divulgação. Ambas empresas possuem centros de criação nos quais a pesquisa e renovação constante são premissas para a inovação e consolidação no mercado. As coleções sazonais também fazem parte da inovação constante nas estratégias das empresas, desenvolvendo produtos temáticos para determinadas datas de comércio varejista. Outra característica recorrente é a comercialização em lojas físicas próprias e também pela venda online em sites de e-commerce. Observando o mercado externo no segmento decorativo, observa-se também que os produtos possuem apelo emocional e diferenciação com design agregado. Isso se dá pelo fato dos produtos serem sempre projetados e criados com o planejamento devido, em centros de pesquisas 
de tendências e verificação constante do público-alvo e clientes. Segundo o portal Varejista, em 2013 os brasileiros gastaram 8\% a mais em artigos de decoração comparado ao ano anterior. Avalia-se que a classe $B$ é a que apresenta maior potencial de consumo com cerca de R\$ 2,3 bilhões gastos em 2013 em artigos de decoração.

Para demonstrar o perfil de possíveis clientes nesse segmento de atuação, elaborou-se um mapeamento baseado em percepções obtidas das análises dos concorrentes verificados, melhor ilustradas na Figura 2.

Figura 2 - Mapeamento do perfil de clientes

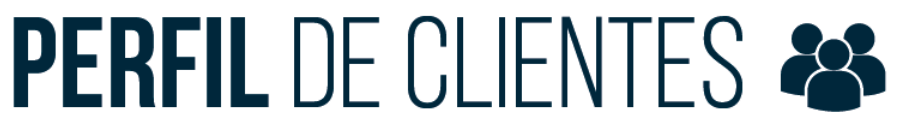

\section{Mapeamento Baseado em Percepções e Possíveis Concorrentes}

- Faixa Etária de 15 a 40 Anos

- Homens e Mulheres

- Classe Ae B

- Consumistas

- Procuram Novidades e Lançamentos diferenciados

- Procuram Envolvimento Afetivo e emocional em produtos

- Preocupam-se com Entretenimento e Lazer

- Lidam com Tecnologia

- Buscam Socialização, Compartilhamento e Inclusão

Fonte: primária (2014)

Conforme Aaker (2001) aborda, alguns consumidores se preocupam com funções superiores e benefícios afetivos ao uso simples e comum de um produto. Tendo em vista a identidade desse perfil abranger homens e mulheres em uma faixa etária ampla, 
percebe-se que esses clientes tendem a ser pessoas que lidam com tecnologias, pois consomem mais produtos pelo acesso de compras e vendas online. Também se verifica que as redes sociais atualmente está presente diariamente na vida das pessoas, as quais buscam socialização, compartilhamento, além de entretenimento e lazer no seu cotidiano, reelegendo produtos que emparelhem nesse perfil.

Contudo, a análise externa apresenta as oportunidades e ameaças verificadas no mercado externo, no Quadro 6 relaciona-se o compilado das verificações realizadas.

\section{Quadro 6-Oportunidades e ameaças}

\begin{tabular}{l|l}
\hline OPORTUNIDADES & AMEACAS \\
\hline $\begin{array}{l}\text { Possível redução de } \\
\text { sucata }\end{array}$ & $\begin{array}{l}\text { Evolução de produtos importados da China } \\
\text { com valores reduzidos }\end{array}$ \\
\hline Sustentabilidade econômica & Cópias de produtos \\
\hline $\begin{array}{l}\text { Diversificação para nova área de } \\
\text { mercado promissora. }\end{array}$ & $\begin{array}{l}\text { Falta de conhecimento da concorrência e } \\
\text { mercado de atuação }\end{array}$ \\
\hline $\begin{array}{l}\text { Possibilidade de planejamento } \\
\text { sustentável pela sucata e resíduos }\end{array}$ & $\begin{array}{l}\text { Falta de posicionamento de mercado e } \\
\text { foco no segmento de produto (novo entrante) }\end{array}$ \\
\hline $\begin{array}{l}\text { Possibilidade na competitividade de } \\
\text { produtos pelo custo }\end{array}$ & Concorrência estabelecida e posicionada \\
\hline Possíveis parcerias e contratações & Lojas físicas estabelecidas além de virtuais \\
\hline
\end{tabular}

Fonte: primária (2014)

As oportunidades e ameaças embasaram-se na análise de duas possíveis empresas concorrentes. Diante disso, verificou-se 
estratégias dessas empresas amparadas pelo composto do Quadro 1 , esse quadro deu suporte como foco de análise tanto externa como internamente.

Devido ao funcionamento empresarial da Grampel ser voltado a um sistema de prestação de serviços industriais, a organização não possui um produto seriado, sendo essa a principal oportunidade de articulação. A ação da empresa limita-se a projetos terceirizados e oriundos de empresas que fazem cotação em diversos outros concorrentes do segmento metalúrgico de corte a laser como a Grampel.

\section{CONSIDERAÇÕES FINAIS}

Para realizar possíveis intervenções do design na indústria Grampel, fez-se necessário um extenso processo de estudo e análises para realização e desenvolvimento de um diagnóstico. Dessa maneira, a presente pesquisa utilizou do aporte teórico da gestão e do marketing como uma oportunidade atrativa de estudo para viabilizar a nova atuação de mercado pretendida. As principais conclusões do diagnóstico estratégico foram apresentadas por meio da ferramenta SWOT, possibilitando aos gestores e colaboradores da indústria uma maneira fluida e com bom senso cognitivo para leitura e compreensão.

Os principais resultados do diagnóstico apontam que, dentro do contexto da Grampel estudado, elimina-se a ideia do desenvolvimento de produtos ser necessariamente o fator primordial para o sucesso e a inovação de uma organização. Buscou-se por meio da pesquisa tornar evidente a importância da compreensão do processo e do Design atuando em serviços para guiar a inovação no desenvolvimento de novos produtos e 
mercados. Pelo recente surgimento e discussão da real atuação acerca do Design em áreas administrativas, é recorrente a dificuldade de integração e entendimento dos designers com os profissionais gestores já atuantes na organização. Visto que a gestão do Design visa organizar e coordenar atividades criativas da organização e com ferramentas desprendidas da concepção tradicional administrativa. Pelo viés administrativo é recorrente deparar-se com gestores não aptos a algumas mudanças estratégicas. Porém, percebeu-se que com a visão interdisciplinar dessa atuação e buscando ferramentas propícias podem-se agregar maiores possibilidades de atuação dos profissionais com as indústrias gerando resultados mais inovadores.

Nesse sentido, esta pesquisa contribuiu no desenvolvimento da ciência e da prática no que diz respeito às áreas de Design, gestão, inovação e marketing na indústria. $O$ estudo sugere ainda ser pertinente aprofundar algumas abordagens teóricas, visto que a pesquisa limitou-se ao diagnóstico estratégico, podendo enriquecer em desdobramentos futuros com os pilares da sustentabilidade, desenvolvimento de produtos e outros campos de conhecimento que o designer pode contribuir com a indústria, propondo soluções tangíveis e aplicáveis.

Repensar os processos e diagnosticá-los por meio do design representa possíveis melhorias e inovações em uma organização, dessamaneirapode-segarantirmaior competitividademercadológica e ainda contribuir de maneira acadêmica para possíveis novos desdobramentos de estudo. 


\section{REFERÊNCIAS}

AAKER, D. A. Administração estratégica de mercado. 5. ed. Porto Alegre: Bookman, 2001.

FORTY, A. Objeto de desejo: design e sociedade desde 1970. São Paulo: Cosac Naify, 2007.

LÖBACH, Bernd. Design Industrial: bases para configuração de produtos industriais. São Paulo: Edgard Blücher, 2001.

MARTINS, Rosane Fonseca de Freitas; MERINO, Eugenio Andrés Díaz. Gestão de Design como estratégia organizacional. 2. ed. Londrina: EDUEL, 2011.

MOZOTA, Brigitte Borja de. Gestão do Design: usando o design para construir valor de marca e inovação corporativa. Porto Alegre: Bookman, 2011.

NESE, L. O Design como Serviço Essencial. In: Innovation Idea Brazil. São Paulo: Imprensa Oficial, 2010.

PORTAL GRAMPEL. Soluções em corte a laser (Joinville, SC). Disponível em: <http://www.grampel.ind.br>. Acesso em: 14 out. 2013. 



\section{Diretrizes de design de interfaces para terceira idade: guia projetual para o desenvolvimento de interfaces em refrigeradores voltados ao público idoso}

Victor Henrique Fagundes (Currículo Lattes) Adriane Shibata Santos (Currículo Lattes)

\section{INTRODUÇÃO}

A crescente evolução tecnológica computacional e a rápida disseminação da interatividade virtual são fatores que vêm direcionando a sociedade para uma constante adaptação aos novos cenários e padrões tecnológicos aos quais está invariavelmente sendo inserida.

Nos dias atuais, considerando a rotina de uma grande cidade, as pessoas estão propícias a inúmeras interações com diversos tipos de tecnologias, desde um simples acionamento do elevador ao sair de casa, por meio do painel de um carro, em um caixa automático de banco, até mesmo ao utilizar um telefone. Estes e muitos outros 
momentos fazem com que as pessoas tenham, de alguma maneira, contato com a tecnologia em forma de sistemas interativos.

Atualmente se entende por interação humano-computador o campo de estudo interdisciplinar, que tem como objetivo compreender como e por que as pessoas utilizam (ou não utilizam) a tecnologia da informação, focando no estudo de como projetar, implementar e utilizar sistemas computacionais interativos (SANTA ROSA; MORAES, 2008).

Segundo Preece et al. (2005), o objetivo do estudo da interação entre homem-máquina é trazer a abordagem da usabilidade para dentro do processo de desenvolvimento deses sistemas. Na essência, o desafio é criar produtos interativos que sejam fáceis, eficientes e amigáveis ao uso, pela perspectiva dos usuários.

Sendo assim, a usabilidade, que tem em sua essência a busca por uma simbiose entre interface, usuário, tarefa e ambiente, no processo de desenvolvimento de produtos físicos ou digitais, com o tempo assumiu importância muito maior do que no passado, quando os usuários só experimentavam a usabilidade do produto após a compra (SANTA ROSA; MORAES, 2008).

Nesse processo evolutivo, os resultados que possivelmente se tornaram mais constantes e intensos foram os que envolviam os computadores pessoais e seus programas. Sua evolução fez com que se tornasse a mais popular de todas as máquinas e a responsável por uma revolução nos hábitos e na atual organização social, impulsionados pela disseminação da tecnologia touch, a qual trouxe para o mercado uma nova referência de interação.

Esse movimento impôs uma rápida adaptação nos demais setores industriais, fazendo com que monitores de computador, televisores, máquinas fotográficas, filmadoras, entre outros, incorporassem esse tipo de tecnologia, conforme representado na Figura 1. 
Figura 1 - Aplicação da tecnologia touch em vários segmentos
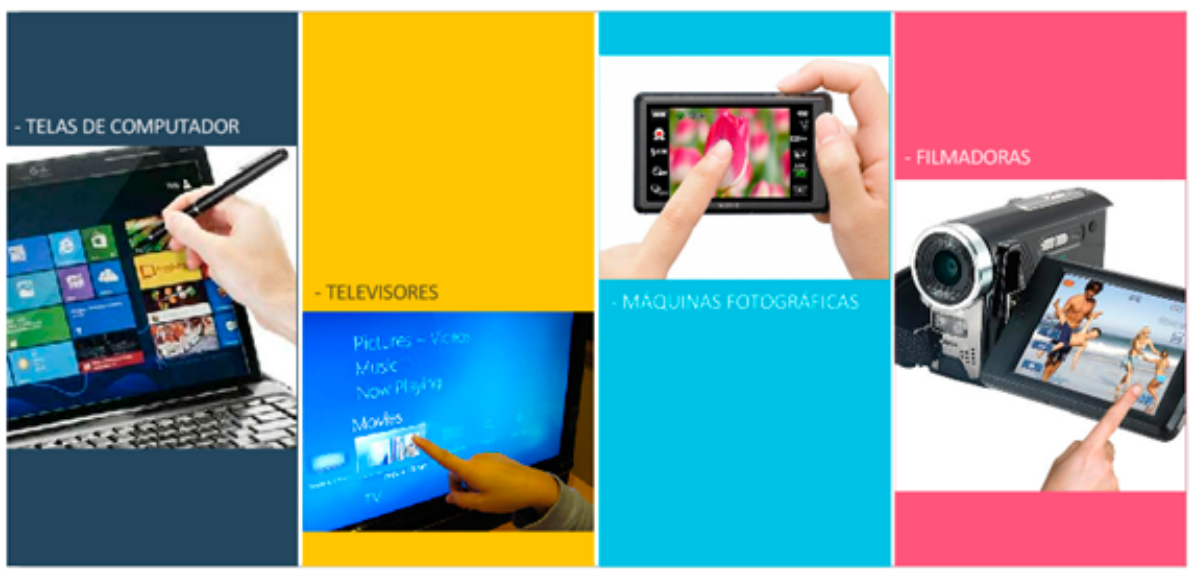

Fonte: Fagundes (2015)

Entre os grandes segmentos industriais de bens de consumo, o mais recente movimento no sentido da aplicação de novas tecnologias de interação foi o setor de eletrodomésticos, que no fim da primeira década de 2000 começou a expor espaços em feiras de tecnologias junto os eletroeletrônicos. Na lista dos que mais sofreram intervenções nesse sentido está o refrigerador, que é um dos eletrodomésticos mais presentes no cotidiano das famílias brasileiras.

Essa crescente demanda fez com que a categoria recebesse maior atenção nas indústrias do segmento por meio da incorporação de um grande número de incrementos tecnológicos, ilustrados na Figura 2. 
Figura 2 - Refrigeradores nacionais com interface touch

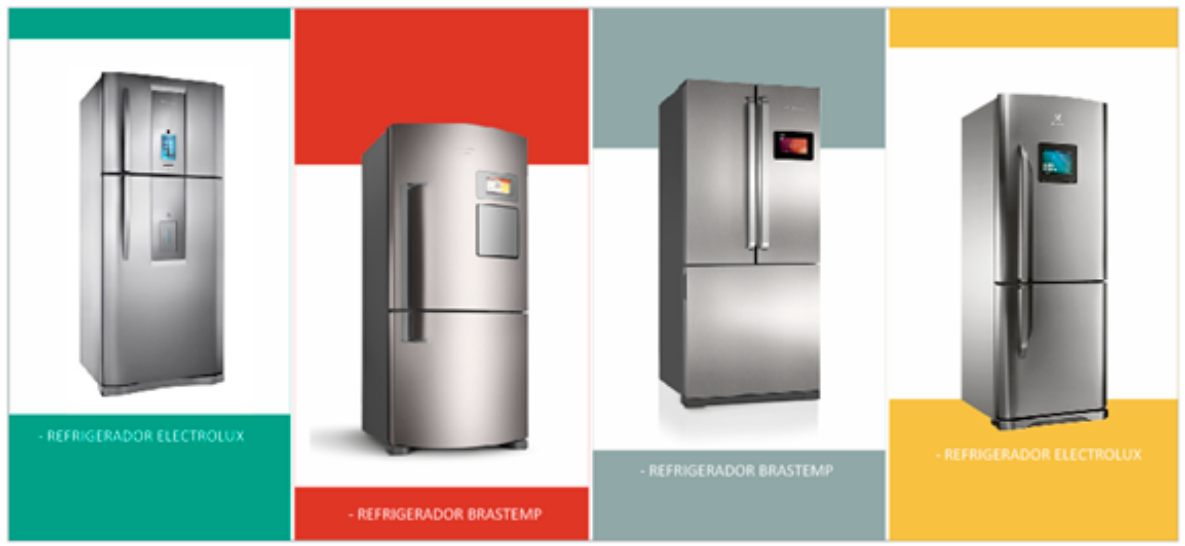

Fonte: Fagundes (2015)

Paralelamente a esses acontecimentos, e a exemplo do que já vem acontecendo no cenário internacional, a última Pesquisa Nacional por Amostra de Domicílios (PNAD) (IBGE, 2013) mostrou que o Brasil vem sofrendo profundas alterações na base e no topo da pirâmide nas últimas décadas. Amparado pela maior expectativa de vida, há um aumento acentuado no número de idosos, enquanto os grupos de 0 a 24 anos sofrem uma contínua redução.

Considera-se idosa a pessoa com 60 anos ou mais, de acordo com a recomendação da (OMS - World Health Organization [WHO]) para países em desenvolvimento (WHO, 2014). No mesmo relatório da PNAD 2012, é possível encontrar algumas projeções baseadas nos dados levantados, as quais mostram que em 2030 o grupo de idosos de 60 anos ou mais será maior que o grupo de crianças com até 14 anos de idade, e em 2055 a participação de idosos na população total será maior que a de crianças e jovens com até 29 anos de idade, fazendo com que o Brasil deixe de ser um país jovem para se tornar um país em sua grande maioria maduro. 
Essas transformações trazem não apenas alterações econômicas, mas também sociais e comportamentais. Considerando que as novas gerações demonstram cada vez mais intimidade e atração pelos artefatos tecnológicos e, assimilando facilmente as mudanças, a geração adulta e mais velha, nascida anterior à disseminação do universo digital e da internet, ainda não consegue acolher e extrair tranquilamente os benefícios dessas tecnologias com a mesma facilidade de assimilação dos jovens.

Essa questão tem se tornado mais importante com a crescente popularização da internet, o que evidencia a necessidade de se pensar diretrizes de acessibilidade na web, abrindo os caminhos para que mais pessoas possam se sentir incluídas nessa sociedade tecnológica. Para Vieira e Santa Rosa (2014), os idosos que utilizam o computador sentem-se menos excluídos e melhoram sua conexão com o mundo externo.

O fato é que, consciente ou inconscientemente, desconsiderando as implicações sociais relacionadas ao envelhecimento, designers deixam de auxiliar no processo de socialização tecnológica e de agregar tanto valor quanto poderiam a produtos e softwares.

Diante desse quadro surge o seguinte questionamento: como melhorar a relação de uso entre os usuários da terceira idade e refrigeradores, considerando os avanços tecnológicos das interações no segmento de eletrodomésticos?

A partir desse questionamento, a pesquisa aqui apresentada teve por objetivo principal trazer melhorias a pessoas da terceira idade nas relações de uso de eletrodomésticos dotados de tecnologias de interação. Buscou o entendimento do processo de design de interfaces, bem como a aplicação de suas ferramentas voltadas à arquitetura da informação, necessidades dos usuários e diretrizes de usabilidade, descritos a seguir. 


\section{DESIGN DE INTERFACES}

A área de design de interfaces, ou design de interação humanocomputador, tem como objetivo principal o projeto edesenvolvimento de interfaces com o propósito de aprimorar sistemas computacionais nos quais usuários possam executar suas tarefas com segurança, eficácia e satisfação (SANTA ROSA; MORAES, 2008).

Resumidamente, o processo de design de interfaces requer o entendimento das necessidades dos usuários, equilibrando conceitos de design a funcionalidades técnicas, pautados pelas diretrizes de usabilidade, conforme Figura 3.

Figura 3 - Processo básico de design de interfaces

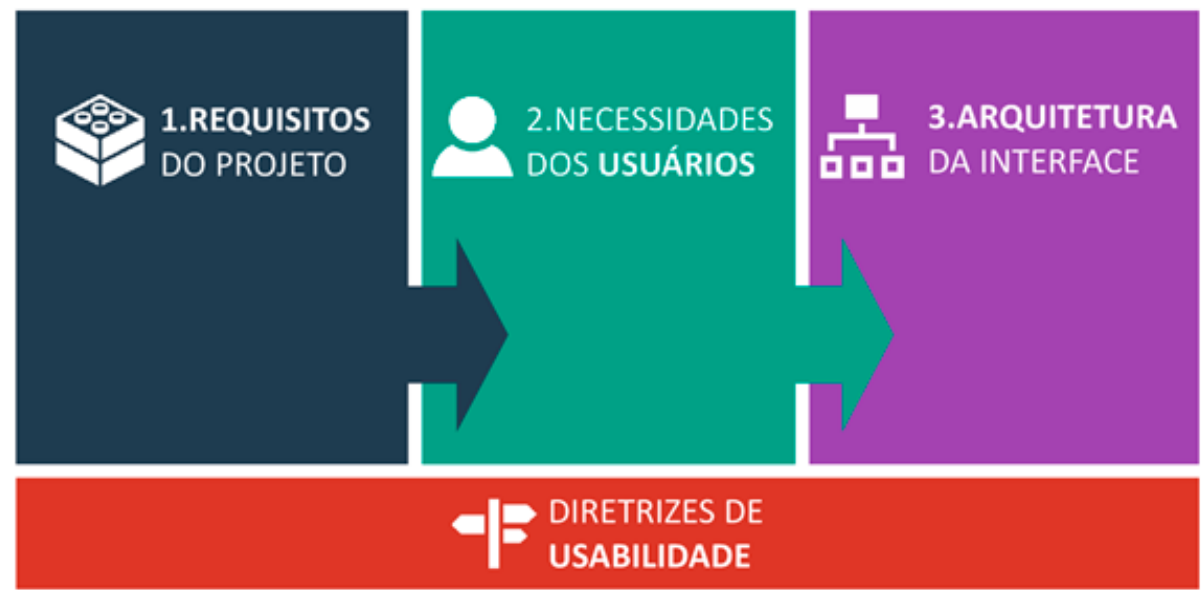

Fonte: Fagundes (2015)

Este projeto não teve por objetivo o desenvolvimento de uma interface, mas sim de diretrizes projetuais, de modo que o processo aplicado partiu de uma análise da arquitetura de informação das principais interfaces de refrigeradores existentes no mercado nacional, para então posteriormente entender as necessidades dos usuários da terceira idade e finalmente propor as diretrizes para o 
desenvolvimento de interfaces para refrigeradores voltadas ao público da terceira idade.

Para essas atividades foram selecionados três modelos de refrigeradores: 1) Brastemp Side Inverse 540 litros, 2) Electrolux I-Kitchen 542 litros e 3) Brastemp Ative 429 litros, apresentados com suas características na Figura 4.

Figura 4 - Produtos selecionados e suas principais características

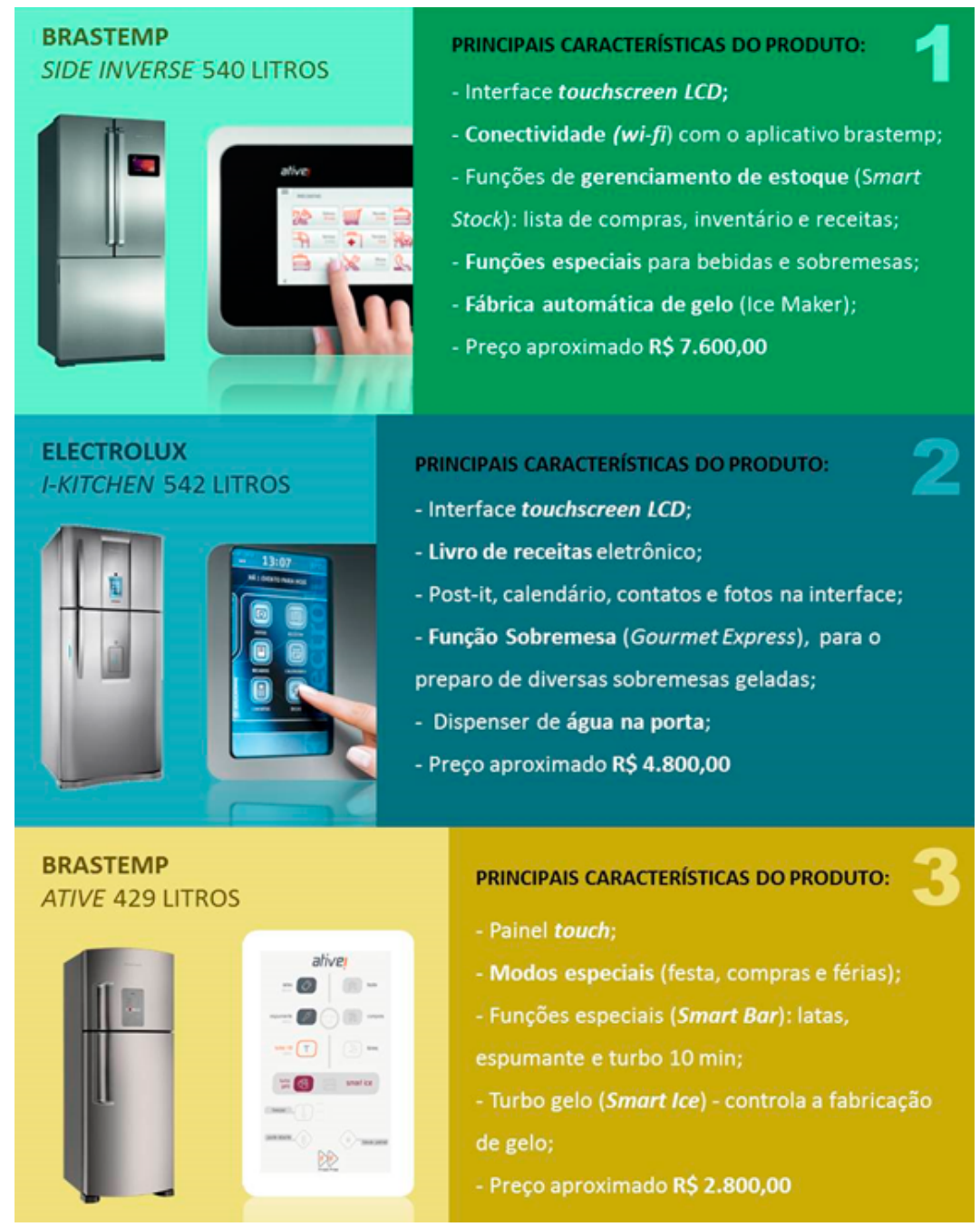

Fonte: Fagundes (2015) 
Para compreender a arquitetura das três interfaces, optou-se por estruturar uma análise baseada nos princípios de arquitetura da informação descritos por Spencer (2010), porém foram considerados apenas os itens relacionados à estrutura geral e elementos de navegação, sendo:

a) Características gerais: de maneira geral, verificou-se que as três interfaces apresentam características tecnológicas distintas entre elas, desde PCB (placa impressa com tinta condutiva sensível ao toque), que é considerado o modelo mais barato de tecnologia touch, até o capacitive touch, que é a mesma tecnologia utilizada nos principais smartphones;

b) Estrutura visual: em se tratando de estrutura visual, as maiores diferenças ficam entre os modelos com telas gráficas navegáveis e o modelo com interação em tela única. O modelo Brastemp Ative, por não ser navegável, apresenta características mais convencionais, com agrupamento de funções por afinidade e semântica gráfica próxima à utilizada em painéis de controles com botões físicos. Já os modelos Brastemp Side Inverse e Electrolux I-Kitchen trazem características visuais mais elaboradas e seguem padrões amplamente utilizados em tablets e smartphones;

c) Tipos de interação: os três modelos analisados não apresentam novidades quando comparados a outros produtos com tecnologia touch. Toda a navegação é baseada em toques, deslizes verticais e horizontais e pressão por alguns segundos;

d) Padrões de fluxo de trabalho da interface: dois modelos analisados (Brastemp Side Inverse e Electrolux I-Kitchen) apresentam o mesmo tipo de padrão de fluxo de trabalho, baseado em 3 diferentes níveis, com uma estrutura hierárquica bem definida entre a tela inicial, menus e funções. 
Com as 3 interfaces analisadas sob a ótica da arquitetura da informação, foi possível verificar as principais características e diferenciais de cada modelo, bem como torná-los aptos a serem utilizados em pesquisas com usuários, já que o conhecimento prévio dos produtos testados é requisito básico para a execução de testes de usabilidade.

\section{PESQUISA COM PÚBLICO-ALVO}

A presente etapa apresenta o entendimento das necessidades dos usuários da terceira idade. Para alcançar uma maior assertividade e eficácia na abordagem, o público-alvo foi segmentado segundo os seguintes critérios demográficos e psicográficos:

- Pessoas com mais de 60 anos presentes nas classes A e B;

- Ambos os sexos, solteiros ou casados, que possuam smartphones ou estejam habituados com tecnologias de interação.

A partir desta segmentação, optou-se pela aplicação das três ferramentas para o entendimento das necessidades do usuário, sendo o grupo de foco, teste de usabilidade e pesquisa contextual.

O recrutamento dos participantes respeitou diretrizes apontadas na fundamentação teórica da pesquisa e os critérios apresentados anteriormente. Foram então selecionados 15 indivíduos residentes em Joinville/SC e região, 10 mulheres e 5 homens, os quais foram divididos e posicionados nas atividades conforme a Figura 5. Para a definição da proporção de gênero utilizada no recrutamento e na aplicação das ferramentas, considerou-se também como critério a frequência de envolvimento na realização de atividades domésticas deste grupo. 
Figura 5 - Esquema de recrutamento e divisão de usuários

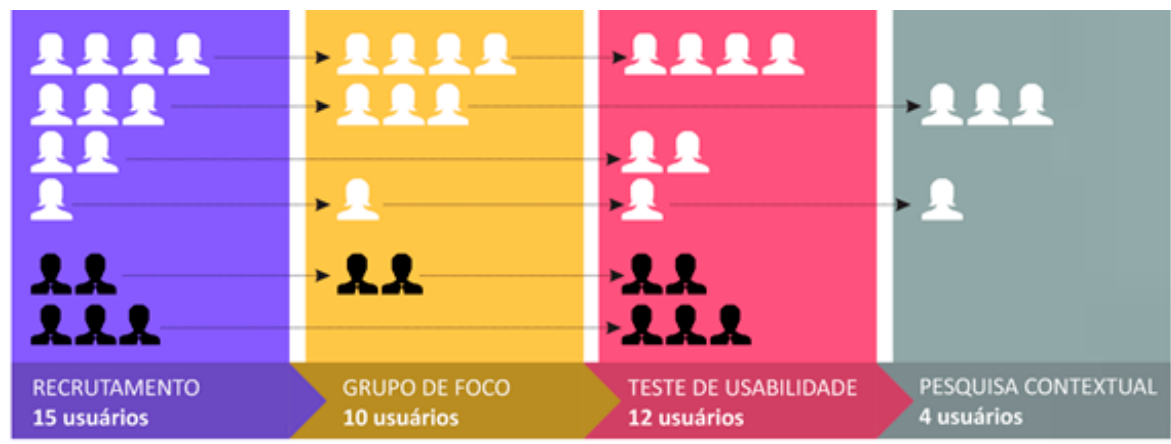

Fonte: Fagundes (2015)

Com o perfil determinado, participantes recrutados e estrutura de aplicação disponível, iniciou-se a execução a partir do grupo de foco, seguido pelos testes de usabilidade e pela pesquisa contextual.

\section{Aplicação do grupo de foco}

A atividade que teve como objetivo compreender (1) como a evolução tecnológica em produtos afeta a rotina nas atividades do lar, em especial no ambiente da cozinha, (2) a relação dos idosos com produtos dotados de tecnologias de interação, e (3) a percepção de benefícios trazidos pelas tecnologias trouxe como principais conhecimento gerados os seguintes tópicos:

1. Quanto à relação dos idosos com as atividades do lar:

- não se consideram idosos e possuem um grande senso de responsabilidade pelo lar em que vivem;

- em se tratando da aquisição produtos, apesar de serem fiéis a alguns modelos e marcas, frequentemente experimentam novidades e lançamentos;

- a segurança é fator predominante em suas escolhas e a família se apresenta como prioridade e o ponto emocional mais forte. 
2. Quanto à relação dos idosos com a tecnologia:

- dependem sempre de um incentivador que apresente e ensine como utilizar artifícios tecnológicos, fazendo com que o uso seja de forma superficial;

- estão habituados a computadores e telas touch e sempre relacionam a tecnologia com a conectividade; - a tecnologia é apontada como uma opção para suprir a solidão e o tempo ocioso, por meio do entretenimento e do uso diário da internet;

- a aceitação e aquisição de produtos tecnológicos estão diretamente vinculadas à confiança e relevância.

3. Quanto aos benefícios das novas tecnologias:

- uxiliam na comunicação e nos relacionamentos com amigos e familiares e permitem organizar melhor o dia a dia por meio de agendas e lembretes;

- facilitam a busca de informações, a localização por meio de mapas e trazem mais opções de entretenimento.

A aplicação dessa ferramenta permitiu o entendimento de diversos fatores que envolvem a relação entre idosos e tecnologias, em especial características voltadas ao interesse e percepções sobre o tema proposto. Destaca-se que, apesar dos entrevistados mencionarem o uso frequente de computadores e smartphones e compreenderem os inúmeros benefícios trazidos pelas evoluções tecnológicas, a relação com produtos providos de tecnologias de interação ainda não se mostra natural e fácil. 


\section{Aplicação dos testes de usabilidade}

A segunda atividade voltou-se à avaliação da usabilidade das interfaces dos três modelos de refrigeradores definidos anteriormente e visou entender a forma de interação e as dificuldades encontradas pelos usuários da terceira idade durante o uso.

Ao todo foram executados doze testes individuais com usuários, seguindo roteiro de quatro tarefas pré-determinadas que trouxeram diversos aprendizados e estão resumidos a seguir:

1. Evitam desbravar a interface - por possuírem dificuldades de localização e navegação pela interface, os usuários idosos entendem que todas as funções oferecidas pela interface se encontram na primeira página e apresentaram dificuldades de interpretação dos diferentes padrões ou lógicas na mesma função.

2. Preferem linguagens diretas - com um aprendizado mais lento, preferem não pensar antes de executar a ação, preferindo linguagens e lógicas de usos claras e diretas.

3. Entram em pânico facilmente - por errarem mais de uma vez a mesma ação, utilizam constantemente a saída de emergência e preferem indicações/pistas claras do caminho a ser seguido.

Devido a suas características observatórias, além da visualização das maiores dificuldades na interação com as interfaces testadas, com a aplicação dos testes de usabilidade também foi possível compreender alguns impactos de características físicas e psicológicas desse público na forma de utilização das tecnologias. Como exemplo, destacam-se a interação com toques menos precisos, dificuldade de leitura em textos com fontes reduzidas e a expressão de culpa ao selecionar um botão ou função equivocadamente. 


\section{Aplicação da pesquisa contextual}

A terceira e última atividade aplicada para o entendimento das necessidades dos usuários foi a pesquisa contextual.

A atividade foi aplicada diretamente no ambiente doméstico de 4 participantes do sexo feminino, selecionadas a partir da atividade de grupo de foco, e trouxe informações sobre a compreensão da rotina dos idosos em atividades que envolvessem equipamentos com tecnologias de interação, em especial no ambiente da cozinha, as quais estão resumidamente descritas a seguir:

1. São conservadores nas atividades domésticas - simplicidade e praticidade direcionam as escolhas para o dia a dia do lar onde, apesar de estarem habituados com computadores, tablets e smartphones, optam sempre por produtos menos tecnológicos e já conhecidos.

2. Tecnologia é comunicação - foi possível observar que a tecnologia está sempre ligada a atividades de lazer e representa o canal de contato com familiares e amigos, além de ser uma fonte de informações e entretenimento.

Com os resultados da pesquisa contextual, finalizou-se a aplicação das ferramentas de entendimento das necessidades dos usuários e consequentemente a etapa de pesquisas práticas da metodologia proposta.

\section{DESENVOLVIMENTO DAS DIRETRIZES PROJETUAIS}

Com o objetivo de sobrepor os dados obtidos das diferentes etapas da pesquisa, foi realizada inicialmente uma análise que permitiu tanto a verificação das informações bibliográficas ante os resultados das atividades práticas, quanto confrontar afirmações dos 
usuários nos grupos de foco e atitudes observadas nas pesquisas contextuais.

O resultado dessa análise gerou um grupo de sete diretrizes, as quais buscam abranger de forma sucinta os principais conhecimentos gerados na pesquisa, sendo desde tópicos voltados ao significado da aplicação das tecnologias de interação em refrigeradores, até elementos que visam auxiliar no direcionamento do projeto da arquitetura da interface.

As diretrizes foram elaboradas para compor o processo de desenvolvimento de interfaces para refrigeradores e atuar como estímulo à reflexão sobre o público da terceira idade, e o resultado está em forma de infográfico na Figura 6. 
Figura 6 - Desenvolvimento gráfico das diretrizes propostas

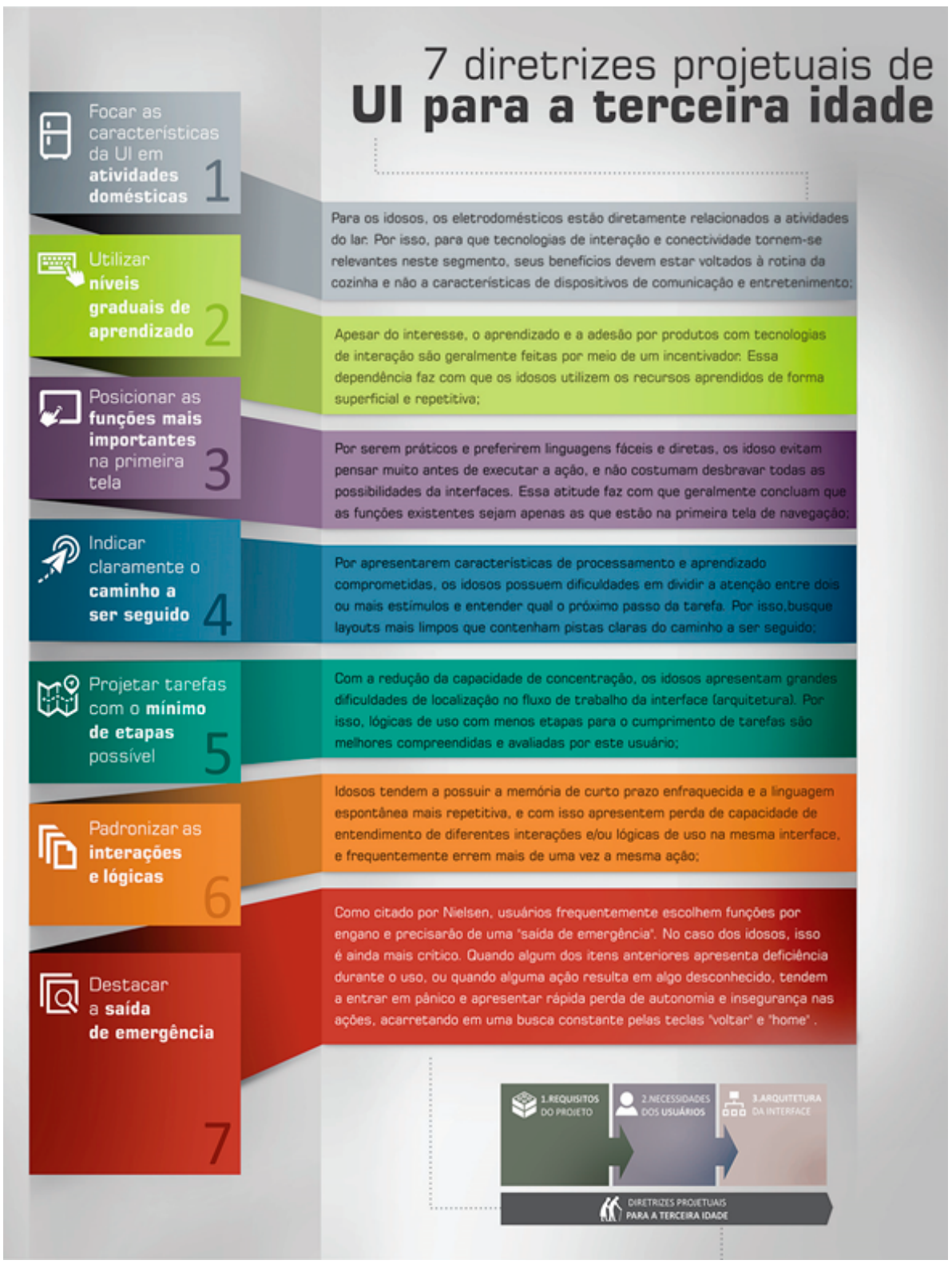

Fonte: Fagundes (2015) 


\section{CONSIDERAÇÕES FINAIS}

Entendendo o contexto em que projetistas de interfaces estão inseridos, pode-se considerar, pelo resultado apresentado, que as diretrizes venham a se tornar uma ferramenta influenciadora no que diz respeito ao processo de desenvolvimento de novas interfaces para refrigeradores, tornando-se um conjunto de informações e premissas que podem auxiliar na composição de projetos que façam sentido para o público da terceira idade.

DesSe modo, a pesquisa resultou numa ampla reflexão sobre a relação do idoso com a tecnologia, cujo desfecho conclusivo é o guia projetual para novas interfaces com foco na terceira idade.

Vale ressaltar que, considerando as diversas diretrizes de usabilidade existentes, que de certa forma atendem ao público da terceira idade, o resultado desta pesquisa não compreende a substituição dos modelos atuais, mas sim sua aplicação como complemento e suporte a projetos que favoreçam esses usuários. 


\section{REFERÊNCIAS}

FAGUNDES, V. H. Diretrizes de design de interfaces para terceira idade: guia projetual para o desenvolvimento de interfaces em refrigeradores voltados ao público idoso. 2015. 96 f. Dissertação (Mestrado em Design) - Universidade da Região de Joinville-Univille, Joinville, 2015.

IBGE - Instituto Brasileiro deGeografia eEstatística. Pesquisa Nacional por Amostras de Domicílios 2012. Disponível em: <http://www. ibge.gov.br/home/estatistica/populacao/trabalhoerendimento/ pnad2012/default_brasil.shtm>. Acesso em: 10 mar. 2013.

NIELSEN, J. Usability Engineering. Mountain View, CA, EUA: Academic Press,1993.

PREECE, J.; ROGERS, Y.; SHARP, H. Design da Interação: além da Interação homem-computador. Porto Alegre: Bookman, 2005.

SANTA ROSA, J. G.; MORAES, A. M. Avaliação e projeto no design de interfaces. Teresópolis, RJ: 2AB, 2008.

SPENCER, D. A Practical Guide to Information Architecture. United Kingdom: Five Simple Steps, 2010.

VIEIRA, M. C.; SANTA ROSA, L. M. C. O uso do computador e da Internet e a participação em cursos de informática por idosos: meios digitais, finalidades sociais. In: SIMPÓSIO BRASILEIRO DE INFORMÁTICA, XX, 2009, Florianópolis. Disponível em: <http://www.niee.ufrgs.br/ eventos/SBIE/2009/conteudo/artigos/completos/61684_1.pdf >. Acesso em: 18 mai. 2014.

WHO. World Health Organization. Disponível em: <http://www. who.int/en/>. Acesso em 23 mar. 2014. 



\title{
0 protagonismo do design e suas contribuições no terceiro setor
}

\author{
Rosangela Canônica (Currículo Lattes) \\ Rita Inês Petrykowski Peixe (Currículo Lattes) \\ Adriane Shibata Santos (Currículo Lattes)
}

\section{INTRODUÇÃO}

Desde muito, o uso do design tende a constituir-se como uma importante ferramenta para a diferenciação e aprimoramento de performances, permitindo ser aplicado a diversos contextos. Por meio dele, é possível que novas estratégias possam ser integradas à proposta de valor de diferentes organizações. Como processo, pode gerar resultados concretos que melhoram a qualidade do trabalho organizacional, visto que seu caráter multidisciplinar e interativo permite o uso da criatividade como capital essencial de planos e ações que conduzem equipes de trabalho a criar respostas positivas a desafios diversos, de maneira colaborativa. 
No contexto do terceiro setor - entendido como aquele que inclui questões de intervenção e melhoria social - as contribuições do design "divergem" das aplicáveis às organizações do segundo setor, por possuírem realidades bem distintas. Como num contexto de terceiro setor, as organizações não objetivam lucro nem apresentam diferencial competitivo, seu uso transpõe a lógica do desenvolvimento de produtos originalmente proposta no âmbito do design, mediando caminhos que contribuam para criar melhores performances institucionais, sobretudo relacionadas às práticas educativas com pessoas inseridas em projetos de geração de trabalho e renda, possibilitando ampliação de conhecimentos e capacidades técnicas a àqueles que detêm menos oportunidades de acesso.

Com esse foco, o presente artigo, sendo parte da dissertação de mestrado intitulada 'Contribuições do design em contexto do terceiro setor', descreve o design como impulsionador de iniciativas para alavancar estratégias diferenciadas de atuação em organizações do terceiro setor. Sobretudo, apresenta métodos que contribuem para mediar a busca pela descoberta de novas performances utilizando o design thinking ${ }^{1}$ como parâmetro capaz de orientar a gestão de novas ideias, métodos e ferramentas de trabalho nos contextos da educação empreendedora.

\section{DESIGN E PERFORMANCE ORGANIZACIONAL}

Qual seria, atualmente, a importância do design na diferenciação de performances organizacionais?

Para Brown (2010), o design não se constitui como uma simples resposta. Sua essência é a chave para perguntas mais assertivas para 
a resolução de problemas mais complexos, gerando alternativas impactantes, sustentáveis e inovadoras. Essa habilidade projeta uma visão profundamente humana para o fazer design, desenvolvendo soluções que tenham significado emocional além do funcional para a vida das pessoas.

Partindo de uma visão mais ampliada, Fontoura (2002) afirma que o design é um vasto campo que envolve e converge para diferentes disciplinas. Portanto, ele pode ser visto como uma atividade, como um processo, ou entendido em termos de resultados tangíveis. Abrange também a função de gestão de projetos, atividade projetual, atividade conceitual, ou ainda como um fenômeno cultural. É tido como um meio para adicionar valor às coisas produzidas pelo homem e também como um veículo para as mudanças sociais e políticas.

De acordo com Mozota (2011), para tornar o design compreensível a quem não é especializado na área, determinados assuntos e questões devem ser considerados. Primeiro, deve-se descrever a natureza da profissão, compreendendo as diversas áreas em que o design é praticado e os vários métodos que os profissionais de design empregam em seu trabalho. A partir desse ponto, é preciso perceber a relevância do design para a ciência da administração, descobrir o que se pode aprender com o processo criativo e, por conseguinte, medir o impacto sobre a performance organizacional a fim de determinar o que se pode auferir com ele. Afinal, o "design é uma atividade fundamental, com ramificações capilares em todas as atividades humanas" (BONSIEPE, 1997, p. 15).

Para Mozota (2011), as técnicas de design conectam o caráter lógico da abordagem científica às dimensões intuitivas e artísticas do trabalho criativo,estabelecendo umelo,complementarefundamental, entre arte e ciência. Seu posicionamento é, portanto, como atividade 
de resolução de problemas, um exercício criativo, sistemático e de coordenação, o que implica dizer que sua aproximação com a gestão se dá pela soma das mesmas características. Para a autora, o designer, devido à sua natureza, inspira a mudança e projeta novas ideias na medida em que as dimensões culturais e imaginativas do design estão fortemente relacionadas a metas institucionais estratégicas, geradas pela visão organizacional e construção de sua identidade corporativa.

De modo geral, o design fala de pessoas e como elas são colocadas no centro dos processos para construir valor com elas e para elas. Nesse sentido, o presente estudo parte da premissa de uma cultura de inovação fundamentada no design como processo de condução de novas performances para organizações do terceiro setor.

Para Pinheiro e Alt (2011), a prática de inserir o design como modelo de gestão se traduz fundamentalmente no resgate de valores essenciais do design e na aplicação desses valores nas estratégias organizacionais, de maneira a fomentar processos sistemáticos de alta relevância e impacto positivo às pessoas. Sua contribuição se baseia em um novo olhar com um enfoque de inovação que valoriza relações interpessoais e traz sentido tanto para os colaboradores da organização quanto para seu público-alvo.

De acordo com Brown (2010), é preciso que haja muito mais pessoas dispostas a ir além da identificação de problemas ou da crítica às ideias que não deram certo e que se dediquem a buscar soluções. Pois, diante dos desafios que se apresentam hoje, cada sujeito pode fazer sua parte, comprometendo-se com a busca de novas oportunidades. Para tais pressupostos, o autor compreende que existem métodos e habilidades desenvolvidos que podem ser usados para a resolução de problemas mais importantes e 
desafiadores. Seus métodos baseiam-se em um pensamento de design que pode ser compartilhado, aprendido e utilizado por qualquer pessoa e aplicado a diferentes cenários. Trata-se de um modelo mental comprometido especificamente em propor soluções, atrelando importantes conceitos, desenvolvido por designers ao longo das muitas décadas da profissão.

Estima-se que muitos problemas fazem parte do dia a dia das organizações que se comprometem com causas sociais. Além de gerir dificuldades relacionadas à situação de exclusão social na qual seu público beneficiado se encontra, como falta de renda que impacta em condições indignas de moradia, fome, violência, entre outras situações de conflito, outros fatores precisam ser considerados: as organizações precisam administrar metas institucionais relacionadas a número de beneficiados, captação de recursos, índices de exposição em mídias, entre outros contextos da gestão organizacional, incluindo o desenvolvimento de estratégias para atingir resultados cada vez mais assertivos ante o público que se propõem atender. Sob esse último aspecto, o design pode vir a contribuir com competências estratégicas para possibilitar melhores resultados, conforme nos aponta Herrero Filho (2011) ao se reportar às disciplinas essenciais à execução de estratégias organizacionais. O autor considera que o design representa uma das mais importantes abordagens para o desenho e redesenho de processos na organização, na medida em que acelera a criação de valor e busca por novas oportunidades de inovação.

Uma respeitável observação advém de Mozota (2011), ao apontar que a inovação pode ser estimulada com o aumento de conhecimento sobre a natureza da solução de problemas criativos na organização. Isso ocorre na medida em que uma maior consciência sobre as formas de tratamento de problemas gera percepções 
para novas abordagens. Esse entendimento aplicado ao contexto do terceiro setor projeta que novos caminhos podem ser traçados, não apenas para atingir êxito nos resultados, mas, principalmente, sobrevivência.

\section{O MODELO MENTAL DO DESIGN THINKING}

Para Vianna et al. (2012), foi buscando novos caminhos para a inovação que se criou o que hoje é conhecido como "design thinking", uma abordagem que se refere à maneira do designer pensar. Tal pensamento foca, essencialmente, no ser humano, que vê na multidisciplinaridade colaboração e tangibilização de pensamentos e processos, caminhos que conduzem a soluções inovadoras. Pois, ao desafiar os padrões de pensamento, comportamentos e de sentimentos, os "design thinkers" produzem soluções que geram novos significados e que estimulam os diversos aspectos (cognitivo, emocional e sensorial) abarcados na experiência humana.

Deacordo com Herrero Filho (2011), o design thinking representa uma das mais importantes ferramentas de inovação, pois explica como os procedimentos internos estão integrados à estratégia organizacional. Assim, aplicando seu conceito às disciplinas da execução das estratégias organizacionais, contribui-se, e muito, para se superar níveis de insatisfação, bem como para melhorar a forma de como os processos internos e externos são conduzidos. É importante ressaltar que o design thinking é uma metodologia que possibilita imaginar estados futuros à visão de uma organização, acelerar a inovação e superar problemas de uma forma criativa.

Brown (2010) assegura que o design thinking constitui-se como uma abordagem à descoberta de fazer algo novo, eficiente e amplamente acessível. Seus pressupostos integram todos os 
aspectos da organização em sinergia com a sociedade, permitindo que equipes possam gerar colaborativamente ideias que sejam implementadas. Além disso, os princípios do design thinking podem ser aplicáveis a uma ampla variedade de organizações, não estando atrelados somente a empresas em busca de novos produtos a oferecer.

No contexto do terceiro setor, é possível eleger e aplicar o design thinking na organização por seus pressupostos criativos, dinâmicos e colaborativos, que contribuem para que as equipes possam identificar e compreender problemáticas vivenciadas dentro da própria estrutura organizacional, carentes por novas estratégias. Diante disso, torna-se presumível avaliar e aplicar mediações orientadas pelo design thinking para o desenvolvimento de modelos de atuação mais pontuais que favoreçam práticas diárias, de modo a mediar oportunidades para melhoria dos processos relacionados à educação empreendedora.

O design thinking se beneficia da capacidade que todos têm para a resolução de problemas, buscando libertar a criatividade. Para chegar a esse ponto, contudo, há um percurso mental a seguir, dividido em fases, conforme a Figura 1:

Figura 1 - Representação das fases do processo de design thinking

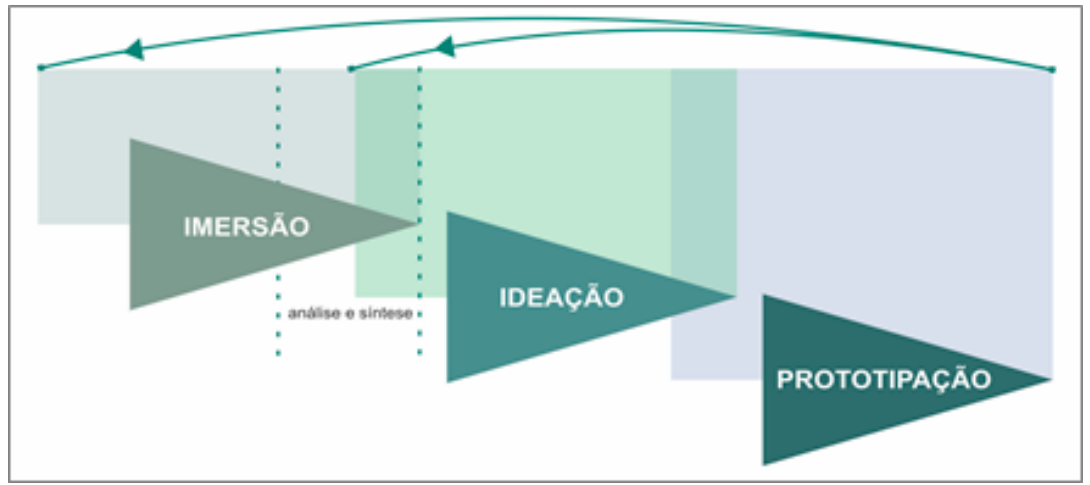

Fonte: primária, baseada em Vianna et al. (2012) 
Todavia, é importante observar, conforme ponderam Vianna et al. (2012), que as etapas que compõem o modelo mental do design thinking não são lineares, pois possuem uma natureza bastante versátil e não linear. Ou seja, tais fases podem ser configuradas de acordo com a necessidade e natureza do problema em questão.

A fase de imersão, na qual há uma aproximação com o contexto do problema, pode ser dividida em duas etapas: preliminar e em profundidade. A primeira fase tem como objetivo o entendimento inicial do problema, enquanto quea segunda destina-seà identificação de oportunidades que irão nortear a geração de soluções durante as fases seguintes; a análise e síntese das informações coletadas durante a fase de imersão têm a finalidade de identificar insights², organizá-los de maneira a obter-se padrões e a criar desafios que auxiliam na compreensão do problema; a fase de ideação tem como intuito gerar ideias inovadoras para o tema do projeto, e, para isso, utilizam-se as ferramentas de síntese criadas na fase de análise para estimular a criatividade e gerar soluções que estejam de acordo com o contexto do assunto trabalhado. Por isso, a fase de prototipação tem como função auxiliar a validação das ideias geradas e, apesar de ser apresentada como uma das últimas fases do processo de design thinking, pode ocorrer ao longo do projeto em paralelo com a imersão e a ideação (VIANNA et al., 2012).

Para cada fase prevista no modelo mental do design thinking há ferramentas que auxiliam diferentes pessoas a utilizarem seus pressupostos para a resolução de problemas, conforme demonstrado no Quadro 1:

2 É o achado proveniente da imersão' a identificação de uma ou mais oportunidades (VIANNA et al., 2012). 
Quadro 1 - Ferramentas que compõem as fases do design thinking

\begin{tabular}{|c|c|c|}
\hline FASE & FERRAMENTA & DESCRIÇÃO \\
\hline \multirow{8}{*}{ Imersão } & Reenquadramento & $\begin{array}{l}\text { Examina problemas ou questões não resolvidas } \\
\text { sob diferentes perspectivas e diversos ângulos. } \\
\text { Assim, desconstrói crenças e suposições } \\
\text { dos atores e, ao quebrar seus padrões de } \\
\text { pensamento, ajuda-os a mudar paradigmas, } \\
\text { impulsionando-os a dar o primeiro passo para } \\
\text { alcançar soluções inovadoras. }\end{array}$ \\
\hline & $\begin{array}{l}\text { Pesquisa } \\
\text { exploratória }\end{array}$ & $\begin{array}{l}\text { Auxilia no entendimento do contexto a ser } \\
\text { trabalhado e fornece insumos para a definição } \\
\text { de demandas e necessidades latentes. }\end{array}$ \\
\hline & Pesquisa desk & $\begin{array}{l}\text { Busca de informações sobre o tema do projeto } \\
\text { em fontes diversas (websites, livros, revistas, } \\
\text { artigos etc.). }\end{array}$ \\
\hline & Entrevistas & $\begin{array}{l}\text { Método de procura direta. As informações } \\
\text { buscadas permeiam o assunto pesquisado e os } \\
\text { temas centrais da vida dos entrevistados. }\end{array}$ \\
\hline & $\begin{array}{l}\text { Cadernos de } \\
\text { sensibilização }\end{array}$ & $\begin{array}{l}\text { Forma de obter informações sobre as pessoas e } \\
\text { seus universos, com o mínimo de interferência } \\
\text { sobre suas ações, ou quando a questão } \\
\text { investigada se desenrola de forma intermitente } \\
\text { ou dentro de um longo período. }\end{array}$ \\
\hline & $\begin{array}{l}\text { Sessões } \\
\text { generativas }\end{array}$ & $\begin{array}{l}\text { Possibilita o encontro com os atores envolvidos } \\
\text { no tema do projeto, para que dividam suas } \\
\text { experiências e realizem juntos atividades nas } \\
\text { quais expõem suas visões sobre os temas do } \\
\text { projeto. Visa, portanto, entender o que sabem, } \\
\text { sentem e sonham, muitas vezes de maneira } \\
\text { tática e latente. }\end{array}$ \\
\hline & Um dia na vida & $\begin{array}{l}\text { É uma simulação, por parte do pesquisador, } \\
\text { da vida de uma pessoa ou situação estudada. } \\
\text { Ou seja, vivencia-se uma situação por um } \\
\text { determinado tempo com objetivo de agir sob } \\
\text { um diferente ponto de vista, interagindo com } \\
\text { os contextos das pessoas com as quais se estaria } \\
\text { confrontando no dia a dia. }\end{array}$ \\
\hline & Sombra & $\begin{array}{l}\text { É o acompanhamento da situação a ser } \\
\text { analisada, com objetivo de entender como a } \\
\text { pessoa se relaciona com o contexto do tema } \\
\text { estudado, que tipo de artefatos e atores estão } \\
\text { envolvidos, quais emoções, expectativas e } \\
\text { hábitos. Assim, identificam-se oportunidades e } \\
\text { necessidades latentes. }\end{array}$ \\
\hline
\end{tabular}

(continua) 
Quadro 1 - Ferramentas que compõem as fases do design thinking (continuação)

\begin{tabular}{|c|c|c|}
\hline FASE & FERRAMENTA & DESCRIÇÃO \\
\hline \multirow{8}{*}{$\begin{array}{l}\text { Análise e } \\
\text { síntese }\end{array}$} & Cartões de insights & $\begin{array}{l}\text { São reflexões embasadas em dados reais } \\
\text { das pesquisas de imersão, transformadas em } \\
\text { cartões que facilitam a rápida consulta e o seu } \\
\text { manuseio. }\end{array}$ \\
\hline & $\begin{array}{l}\text { Diagrama de } \\
\text { afinidades }\end{array}$ & $\begin{array}{l}\text { É uma organização e agrupamento dos cartões } \\
\text { de insights com base em afinidade, similaridade, } \\
\text { dependência ou proximidade, gerando um } \\
\text { diagrama que contém as macroáreas que } \\
\text { delimitam o tema trabalhado, suas subdivisões } \\
\text { e interdependências. }\end{array}$ \\
\hline & Mapa conceitual & $\begin{array}{l}\text { Permite a visualização gráfica, construída para } \\
\text { simplificar e organizar visualmente dados } \\
\text { complexos de campo, em diferentes níveis de } \\
\text { profundidade e abstração. Ilustra os elos entre } \\
\text { os dados e permite que novos significados sejam } \\
\text { extraídos das informações levantadas nas etapas } \\
\text { iniciais da fase de imersão, principalmente a } \\
\text { partir das associações entre elas. }\end{array}$ \\
\hline & $\begin{array}{c}\text { Critérios } \\
\text { norteadores }\end{array}$ & $\begin{array}{l}\text { São diretrizes balizadoras para o projeto, } \\
\text { evidenciando aspectos que não devem ser } \\
\text { perdidos de vista ao longo de todas as etapas } \\
\text { do desenvolvimento das soluções. Surgem da } \\
\text { análise dos dados coletados. Servem como base } \\
\text { para a determinação dos limites do projeto e do } \\
\text { seu verdadeiro propósito. }\end{array}$ \\
\hline & Personas & $\begin{array}{l}\text { São arquétipos, personagens ficcionais, } \\
\text { concebidos a partir da síntese de } \\
\text { comportamentosobservados entre pessoascom } \\
\text { perfis extremos. Representam as motivações, } \\
\text { desejos, expectativas e necessidades, reunindo } \\
\text { características significativas de um grupo mais } \\
\text { abrangente. }\end{array}$ \\
\hline & Mapa da empatia & $\begin{array}{l}\text { Ferramenta de síntese das informações } \\
\text { sobre o público-alvo numa visualização do } \\
\text { que ele diz, faz, pensa e sente. Possibilita a } \\
\text { organização de dados da fase de imersão de } \\
\text { forma a prever entendimento de situações de } \\
\text { contexto, comportamentos, preocupaçóes e até } \\
\text { aspirações dos atores estudados. }\end{array}$ \\
\hline & Jornada do usuário & $\begin{array}{l}\text { É uma representação gráfica que segue } \\
\text { descrevendo os principais passos percorridos } \\
\text { pelo usuário, durante e depois da aquisição e } \\
\text { utilização de algum bem ou serviço. }\end{array}$ \\
\hline & Blueprint & $\begin{array}{l}\text { É uma matriz que representa visualmente, } \\
\text { de forma esquemática e simples, o complexo } \\
\text { sistema de interação que caracterizam uma } \\
\text { prestação de serviços. }\end{array}$ \\
\hline
\end{tabular}

(continua) 
Quadro 1 - Ferramentas que compõem as fases do design thinking (continuação)

\begin{tabular}{|c|c|c|}
\hline FASE & FERRAMENTA & DESCRIÇÃO \\
\hline \multirow{4}{*}{ Ideação } & Brainstorming & $\begin{array}{l}\text { Técnica para estimular a geração de um } \\
\text { grande número de ideias em um curto espaço } \\
\text { de tempo. Geralmente realizado em grupo, } \\
\text { mediado por um moderador, responsável por } \\
\text { deixar os participantes à vontade e estimular } \\
\text { a criatividade sem deixar que o grupo perca o } \\
\text { foco. }\end{array}$ \\
\hline & $\begin{array}{l}\text { Workshop de } \\
\text { cocriação }\end{array}$ & $\begin{array}{l}\text { Encontro organizado na forma de uma série de } \\
\text { atividades em grupo com objetivo de estimular } \\
\text { a criatividade e a colaboração, fomentando a } \\
\text { criação de soluções inovadoras. }\end{array}$ \\
\hline & Cardápio de ideias & $\begin{array}{l}\text { Representa um catálogo de todas as ideias } \\
\text { geradas no projeto. Pode incluir comentários } \\
\text { relativos às ideias, eventuais desdobramentos e } \\
\text { oportunidades de interesse. }\end{array}$ \\
\hline & $\begin{array}{c}\text { Matriz de } \\
\text { posicionamento }\end{array}$ & $\begin{array}{l}\text { Ferramenta de análise estratégica das ideias } \\
\text { geradas, utilizada na validação destas em } \\
\text { relação aos critérios norteadores, bem como às } \\
\text { necessidades das personas criadas no projeto. O } \\
\text { objetivo desse recurso é apoiar o processo de } \\
\text { decisão, a partir da comunicação eficiente dos } \\
\text { benefícios de cada solução, de modo que as } \\
\text { ideias mais estratégicas sejam selecionadas para } \\
\text { serem prototipadas. }\end{array}$ \\
\hline \multirow{5}{*}{ Prototipação } & $\begin{array}{l}\text { Protótipo em } \\
\text { papel }\end{array}$ & $\begin{array}{l}\text { São representações de interfaces gráficas com } \\
\text { diferentes níveis de fidelidade. Como o próprio } \\
\text { nome sugere, o resultado será em papel. }\end{array}$ \\
\hline & Modelo de volume & $\begin{array}{l}\text { São representações de ideias em níveis de } \\
\text { fidelidade. Desde baixa - com poucos detalhes } \\
\text { - até alta, com a aparência final. }\end{array}$ \\
\hline & Encenação & $\begin{array}{l}\text { É a simulação improvisada de uma situação, que } \\
\text { pode representar diferentes intenções. }\end{array}$ \\
\hline & Storyboard & $\begin{array}{l}\text { É a representação visual de uma história por } \\
\text { meio de quadros estáticos, compostos por } \\
\text { desenhos, colagens, fotografias ou qualquer } \\
\text { outra técnica disponível. }\end{array}$ \\
\hline & $\begin{array}{l}\text { Protótipo de } \\
\text { serviços }\end{array}$ & $\begin{array}{l}\text { É a simulação de artefatos materiais, ambientais } \\
\text { ou relaçôes interpessoais que representam } \\
\text { um ou mais aspectos de um serviço, de forma } \\
\text { a envolver o usuário e simular a prestação da } \\
\text { solução proposta. }\end{array}$ \\
\hline
\end{tabular}

Fonte: primária, baseado em Vianna et al. (2012)

3 Refere-se a qualquer ato de criatividade coletiva (compartilhado por duas ou mais pessoas) (VIANNA et al., 2012). 
Esse modelo mental reúne as habilidades e características que os designers têm aprendido e desenvolvido ao longo de décadas e representa um próximo passo, que é "colocar essas ferramentas nas mãos de pessoas que talvez nunca tenham pensado em si mesmas como designers e aplicá-las a uma variedade muito mais ampla de problemas" (BROWN, 2010, p. 3).

Uma maneira de contribuir para o design thinking se incorporar por toda uma organização é fazer com que as pessoas participem da experiência. Isso leva a crer que para o design thinking se difundir no terceiro setor será necessário possibilitar às pessoas que atuam nas organizações experimentar seu poder, aplicando-o às suas práticas diárias. Isso significa que, a partir de seus pressupostos, seja possível vislumbrar a superação de desafios e fomentar uma cultura baseada no entusiasmo.

Ainda para Brown (2010), uma atitude de experimentação diz respeito a uma atmosfera de otimismo. Sem o otimismo - a crença inalterável de que as coisas poderiam ser melhores do que são - a disposição de experimentar será continuamente frustrante. Portanto, indivíduos, equipes e organizações inteiras, para colher o poder do design thinking, precisam cultivar o otimismo, pois as pessoas precisam acreditar que têm o poder de criar novas ideias e proposições que atenderão a necessidades não satisfeitas e que terão impacto positivo.

Entre as muitas características que distinguem as práticas do design thinking, está o fato dessa metodologia possibilitar às equipes de trabalho uma ampla compreensão acerca das mais variadas soluções que pretendem identificar. A criatividade impulsionada por suas práticas, conectada ao seu pensamento visual, permite às pessoas a visualização de dados de maneira rápida e holística. Sobretudo, o exercício representa o universo do tema pesquisado, 
colocando em evidência os achados e insights que circunscrevem as ações do projeto, favorecendo principalmente a colaboração da equipe. Esse estímulo para a colaboração por meio de uma visualização permite a estruturação e correlação de dados, além da elaboração de desafios a serem alcançados no projeto a ser proposto. Assim, Brown (2010) considera que palavras e números têm sua utilidade, mas só a representação visual pode, simultaneamente, relevar tanto as características funcionais de uma ideia quanto seu conteúdo emocional.

As práticas visuais permitem uma atitude de experimentação, mantendo abertas novas possibilidades, novos direcionamentos e a disposição de novas soluções. Essas práticas relacionadas aos interesses internos da organização de terceiro setor podem contribuir para o envolvimento e o comprometimento de toda equipe nos processos de atuação, de modo que seus profissionais possam colaborar com conhecimentos e ideias de maneira holística sobre métodos aplicados.

Ainda, no design thinking as práticas visuais são constantes e colaboram para que a fruição aconteça em todo o processo. A Figura 2 representa as técnicas de trabalho utilizadas em diferentes fases para que o estímulo criativo advenha e seja considerado, desde a etapa de imersão até a prototipação. Além disso, é importante enfatizar que os instrumentos utilizados contribuem para uma comunicação visual simples, eficaz e compreensível para expressar ideias. 
Figura 2 - Representação dos processos de trabalho utilizados no design thinking

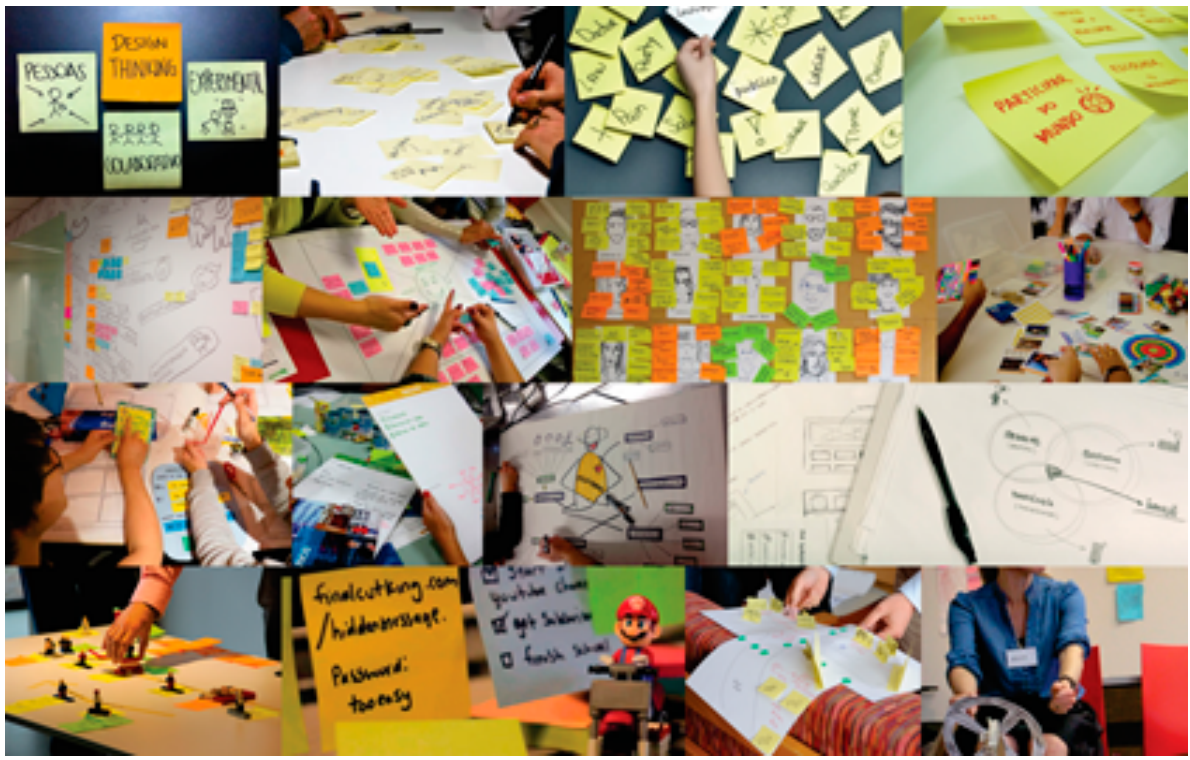

Fonte: primária

Esse direcionamento para a condução de processos de trabalho aplica-se a um ambiente de busca por mudanças. Assegura, essencialmente, que a criatividade individual e coletiva encontre condições de gerar ideias que contribuam para escolhas mais assertivas da organização.

\section{USO DO DESIGN THINKING NA EDUCAÇÃO EMPREENDEDORA: POSSIBILIDADES PARA O TERCEIRO SETOR}

Os pressupostos do Educador Paulo Freire4, acerca de uma educação libertadora, dialógica e socialmente produtiva, compõem os pilares de trabalho das organizações do terceiro setor. Isso

4Educador brasileiro, considerado um dos pensadores mais notáveis no contexto da pedagogia mundial. Destacou-se por seu trabalho na área da educação popular, tanto para a escolarização quanto para a formação da consciência política. 
possibilita que os agentes envolvidos nos processos de inclusão social pelo trabalho vivenciem uma educação socialmente produtiva, combinando desafio e criatividade, o que reflete em mudanças e atitudes, bem como um maior envolvimento e dedicação entre todos para solução de problemas complexos.

Mesmo que não evidenciada, é perceptível a presença do educador Paulo Freire também nos processos de design thinking, tanto no que se refere à adoção de ferramentas de trabalho quanto na abordagem de espaços compartilhados. Tal sinergia enfatiza a importância da autonomia do indivíduo em seus processos, ratificada pelo diálogo e conscientização, os quais propõem ações de colaboração.

É importante considerar que no design social essa relação pode ser mais perceptível, sobretudo por incorporar, além de projetos materiais com resultados tangíveis, ações de ensino e aprendizagem determinantes para o empoderamento de comunidades. Diante de tais questões, as abordagens pedagógicas aplicadas têm como propósito estabelecer bases colaborativas com a responsabilidade de inclusão, mediando a aprendizagem e promovendo a troca de saberes. Tais princípios metodológicos colaborativos favorecem a participação e o envolvimento entre todos os comprometidos nos processos de transformação social.

As práticas participativas (comuns nos pressupostos do design) se fazem presentes nas relações de ensino e aprendizagem ao incluírem diferentes pessoas, trazendo para a negociação múltiplos aspectos de uma mesma situação, pois sustentam a experiência na vivência real da situação, de modo que os agentes envolvidos no processo possam contribuir com seus diferentes saberes para solução de problemas comuns. Como os interesses e vivências são diferenciados para cada pessoa, a negociação torna-se um momento 
no qual uma rica totalidade de visões pode convergir para uma relação dialógica de mudança.

Para Fiori (1987), a pedagogia freireana pensa e pratica um método pedagógico que procura dar ao ser humano a oportunidade de (re)descobrir-se por meio da retomada reflexiva do próprio processo em que vai se descobrindo, se manifestando e se configurando - "método de conscientização". Assim, a consciência do mundo e a consciência de si crescem juntas e em razão direta, sendo uma a luz interior da outra, uma comprometida com a outra. Evidencia-se a intrínseca correlação entre conquistar-se, fazer-se mais si mesmo e conquistar o mundo, fazê-lo mais humano. Mas ninguém se conscientiza separadamente dos demais, esse deve ser um ato coletivo.

Esse conjunto de pressupostos aproxima-se do design thinking, na medida em que tem como foco, essencialmente, o ser humano com vistas à construção de caminhos que conduzem a novas práticas. Aliás, seu escopo metodológico evidencia oportunidades de novas performances nas relações de ensino e aprendizagem, pois o design não considera o conhecimento como transferência de informações (conhecimento como substância). Ele tem uma nova visão de conhecimento como processo de construção coletiva que objetiva o aprender fazendo (aprendizagem cognitiva), a fim de propiciar um contexto para conversações e para a construção social do conhecimento (MOZOTA, 2011).

Entre as muitas contribuições do design thinking aplicado a organizações que buscam a inovação, há uma correlação voltada à educação, em especial aos educadores, de modo a permitir que eles possam construir descobertas sólidas que criam soluções significativas para o atendimento das necessidades relativas ao universo do ensino. Todavia, será que esse mesmo pensamento de 
design não poderia ir ao encontro do atendimento das necessidades de ensino e aprendizagem relativas ao terceiro setor, auxiliando organizações a desenvolverem novas experiências relacionadas a seus métodos?

Para Gonsales et al. (2014), o design thinking possibilita descobrir caminhos sobre o que é "inovação" na prática, prospectando ao universo da educação novas abordagens que visam solucionar problemas e desafios cotidianos de forma colaborativa. No contexto da escola, os educadores estão usando os processos, métodos e ferramentas aprendidos para gerar ideias para suas salas de aula e escolas.

O projeto Design Thinking For Educators, da IDEO (escritório de design global que usa uma abordagem humanística para ajudar organizações dos setores públicos e privados a inovar e crescer), foi dedicado às causas da área da educação, com vistas a contribuir com o empoderamento de educadores diante de problemas complexos. A dedicação a esse projeto gerou a publicação de um roteiro para compartilhamento da metodologia do Design sob uma perspectiva compreensível às pessoas, que podem vir a utilizar seus métodos para superarem, fase a fase, diferentes desafios. De acordo com Gonsales et al. (2014), essa abordagem demanda as seguintes fases (Figura 3):

Figura 3 - Fases do processo "design thinking para educadores".

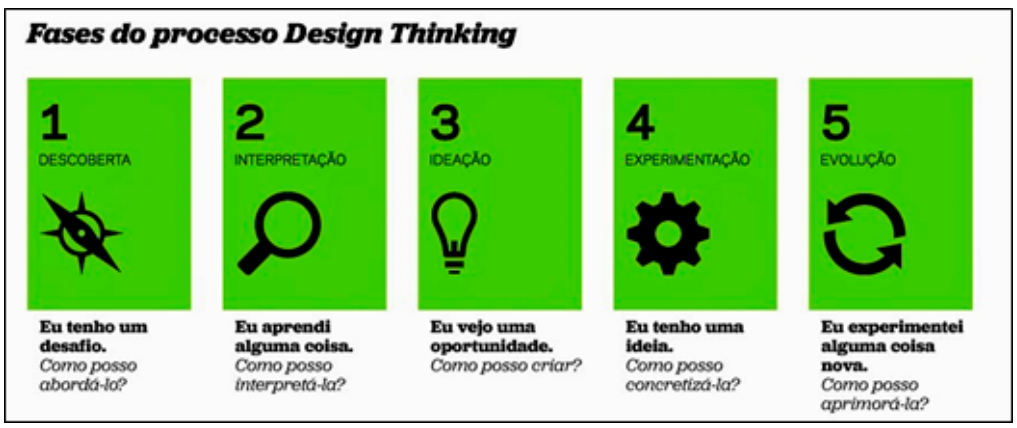

Fonte: Gonsales et al. (2014) 
Esse modelo mental envolve as mesmas fases e ferramentas do design thinking, comentadas no Quadro 1. Porém, pelo fato de seu plano de fundo perpassar o universo das relações de ensino e aprendizagem, cada fase prevista foi idealizada para facilitar a autogestão do educador que se propõe a utilizar seus pressupostos para a resolução colaborativa de problemas, seguindo um percurso essencial para a obtenção de resultados.

Uma importante contribuição do design noâmbito da educação, extensiva ao terceiro setor, refere-se às suas próprias características de aplicar uma abordagem humanística que coloca o ser humano no centro de seus processos. Suas práticas participativas desenvolvem o senso de coletividade, colaboração e da exploração de novas possibilidades e desafios humanos, sobretudo, da experimentação da criatividade como processo de ensino e aprendizagem.

O trabalho das organizações do terceiro setor que atuam com práticas de ensino eaprendizagem com projetos sociais ancora também o complexo percurso de construção do empoderamento de pessoas, incluindo a autoestima, a assunção de responsabilidade consigo próprias e com o coletivo. De acordo com Giannella (2013), essa prática tem chances de ser construída de forma mais sólida e eficaz quando se recorre a processos relacionados à "pedagogia da criatividade". Assim, na medida em que as organizações do terceiro setor atuam mediadas por um processo educativo que faça uso das inteligências múltiplas e, especificamente, das capacidades criativas, expressivas e reflexivas do sujeito, como seu suporte, serão atingidos resultados mais tangíveis e significativos. Pois, a partir de recursos criativos possíveis como a música, canto, dança, desenho e a encenação, tanto teatral quanto performática, da realidade vivenciada-imaginada ou apreendida-, os sujeitos reafirmam sua existência no mundo, vislumbram novas formas de atuação nele, criando novas possibilidades diante os desafios. 
Com base em vivências e pesquisas em curso, pode-se dizer que as experiências no âmbito do terceiro setor também necessitam incluir o Design para que novas metodologias mais convincentes, abrangentes e atraentes possam ser criadas, contribuindo para a reflexão e o desenvolvimento do espírito crítico das pessoas em processo da descoberta empreendedora e, principalmente, para a construção de conhecimento tácito, intuitivo e contínuo de mudança.

Outro ponto relevante para se incluir o design nos caminhos do terceiro setor é colocado por Mozota (2011) quando afirma que o design, por não considerar o conhecimento como informação, mas concepção, o gerencia de modo pró-ativo, de forma que os conhecimentos gerados são utilizados e reutilizados e não armazenados. Nesse sentido, as organizações que acreditam na criatividade e na construção do conhecimento tornam-se, eminentemente, receptivas ao design.

De acordo com Freedman (2003 apud PORTUGAL, 2013), aquilo que as pessoas chegam a saber e como chegam a saber deve romper as fronteiras tradicionais. Enquanto os limites da educação se ampliam e se transformam, as pessoas cada vez mais passam a aprender a partir de formas visuais. Essa importante característica de aprendizagem visual cria espaço para uma educação a partir do design.

Para Portugal (2013), as relações de ensino vêm passando por inúmeras transformações, uma vez que a cultura visual, dada a sua relevância no contexto de aprendizagem, tem sido tema de interesse recente no meio destinado à educação, ainda sujeita a muitas transformações e carente de colaborações, tanto de ordem prática quanto teórica. Por esse motivo, o design como área relacionada à cultura visual é convidado a fazer parte de experiências que possibilitam ampliação dos processos de ensino e aprendizagem, 
incorporando abordagens mais criativas, colaborativas e significativas. Sob esse aspecto, o design thinking se apresenta ao terceiro setor como um importante recurso, passível de inspirar organizações a criarem abordagens que rompam com modelos tradicionais, construindo novos modelos para inovar no âmbito social e multiplicar conhecimentos.

\section{CONSIDERAÇÕES FINAIS}

A pesquisa de mestrado 'Contribuições do design em contexto do terceiro setor' apresentou a possibilidade de se incorporar abordagens voltadas a novas performances de trabalho no terceiro setor por meio do design thinking. Para isso foram investigadas algumas das definições sobre inovação, cujo sentido refere-se ao ato de "fazer algo novo ou renovar", considerando os meios plausíveis para alcançar resultados a partir do design como processo de mediação.

Com ênfase em uma organização tida como estudo de caso, foi possível pensar a diferenciação de performances de trabalho a partir do modelo mental do design, compreendendo sua importância como capital intelectual. A ponderação dessa forma de pensar, de agir e de criar novas possibilidades ao terceiro setor incluiu técnicas e ferramentas de design - dinâmicas e pontuais - na descoberta de melhores oportunidades voltadas à educação empreendedora, tornando-a mais estratégica e eficaz.

Possibilitar o contato do terceiro setor com o modelo mental utilizado por designers para gerar novas ideias levou a organização investigada a reavaliar sua metodologia vinculada à educação empreendedora, de modo a aperfeiçoar processos e incluir melhorias que atendem suas necessidades, tanto internas quanto externas. 
Em decorrência, a experiência demonstrou que é possível utilizar ferramentas de design para enriquecer processos de ensino no contexto social. O conhecimento e uso de tais ferramentas permite aperfeiçoar metodologias e conduzir práticas educativas, tornando a educação empreendedora mais efetiva e próxima da realidade social envolvida. 


\section{REFERÊNCIAS}

BONSIEPE, G. Design do material ao digital. Florianópolis: FIESC/ IEL, 1997.

BROWN, T. Design thinking: uma poderosa metodologia para decretar o fim das velhas ideias. Rio de Janeiro: Elsevier, 2010.

FIORI, E. M. Prefácio. In: Paulo Freire. Pedagogia do oprimido. 17. ed. Rio de Janeiro, Paz e Terra, 1987.

FONTOURA, A. M. Educação de crianças e jovens através do design. 2002. 337 p. Tese (Doutorado em Engenharia de Produção) Universidade Federal de Santa Catarina, Florianópolis, 2002.

GIANNELLA, V. Pedagogia da criatividade: percursos de arte educação no empoderamento de sujeitos para a gestão social integrativa. Revista Interdisciplinar de Gestão Social, 2013.

GONSALES, P. Design thinking para educadores. Instituto Educadigital, 2014. Disponível em: <http://www.dtparaeducadores. org.br> Acesso em: 15 mar. 2014.

HERRERO FILHO, E. Pessoas focadas na estratégia: as disciplinas da execução da estratégia. Rio de Janeiro: Elsevier, 2011.

MOZOTA, B. Borja de. Gestão do Design: usando o design para construir valor de marca e inovação corporativa. Porto Alegre: Bookman, 2011.

PINHEIRO, T. ALT, L. Design thinking Brasil: empatia, colaboração e experimentação para pessoas, negócios e sociedade. Rio de Janeiro: Elsevier, 2011.

PORTUGAL, C. Design, educação e tecnologia. Rio de Janeiro: Rio Books, 2013. 
VIANNA, M. Design thinking: inovação em negócios. Rio de Janeiro: MJV Press, 2012. 



\section{Design de moda e artesanato: uma relação social recíproca}

Rita de Cássia Rothbarth Lorenzi (Currículo Lattes) Elenir Carmen Morgenstern (Currículo Lattes)

\section{INTRODUÇÃO}

Experiências desenvolvidas por professores de Design, numa universidade comunitária catarinense, em projetos de extensão universitária que capacitam para a geração de trabalho e renda, por meio de saberes oriundos do campo do design, destacaram uma problemática em especial: mulheres artesãs, capacitadas a partir de projetos sociais, passam a adotar procedimentos, sob a orientação de professores de Design, e incorporam, em suas produções, modos produtivos pautados em metodologia do campo do design; consequentemente, materiais nativos e técnicas familiares e locais, 
paulatinamente, podem ser abandonados. Em decorrência disso, os artefatos produzidos descaracterizam o grupo que os produz e não integram materiais locais, desconsiderando o meio ambiente. Essa problemática deu luz à reflexão de mestrado intitulada "design de moda e artesanato: uma relação social recíproca", que propôs, de modo integrado aos saberes específicos do campo do design, um retorno às características locais, em busca de uma produção manual que reflita as condições materiais locais e a identidade cultural dos agentes produtores.

Assim, a investigação, ora relatada, apresentou como objetivo geral verificar a contribuição dos estudos fundados na abordagem social, para o campo do design de moda, visando aplicabilidade com projetos que visam geração de trabalho e renda, por meio de processos artesanais. Intentou identificar e analisar possibilidades de colaboração entre professores de Design (integrantes do Departamento de Design da Univille) e artesãs dos projetos que capacitam para a geração de trabalho e renda, desenvolvidos pela Área de Extensão Universitária da Univille (Projetos SempreViva, AmaViva e Vida em Flor). Entendendo que as produções de tais grupos são situadas geográfica e historicamente, intencionou-se fomentar o desenvolvimento de novos artefatos, integrando-se ferramentas e tecnologias acadêmicas do campo do design de moda com os conhecimentos populares de técnicas, processos e materiais locais, compreendendo, em tais práticas, a relevância de estabelecer uma relação social recíproca.

\section{CONTEXTUALIZANDO O CAMPO DE ESTUDO}

A metodologia da investigação apoiou-se naTeoria dos Sistemas Simbólicos, de Pierre Bourdieu. Para Bourdieu (2003, p. 65), não basta 
analisar o objeto de estudo isoladamente, é necessário sopesar o campo no qual está inserido e considerar o sistema simbólico nele instituído. A questão central desta investigação foi a de buscar respostas sociológicas, ou seja, lógicas e ao mesmo tempo empíricas (BOURDIEU, 2007). O viés sociológico, elegido para a investigação, conduziu ao entendimento de que os agentes envolvidos no processo analisado têm sua responsabilidade, mas são em grande parte definidos em suas possibilidades ou impossibilidades, pela estrutura na qual estão situados e pela posição que ocupam nessa estrutura. Não se compreende nada se não se compreende o campo que o produz e que lhe confere pequena força (BOURDIEU, 1997, p. 78).

A Teoria do Campo, de Bourdieu (2003, p. 65), refere-se às questões de legitimação, decorrentes de padrões culturais, dos campos simbólicos. O campo é o espaço social (simbólico) de conflito onde as relações sociais (efetivadas pelos agentes e por classes de agentes) estão distribuídas na forma de capital, seja simbólico, seja cultural, e por meio das quais se estabelecem as relações de dominação. O campo é articulado pelas lutas, disputas pelo poder, entre os agentes, sempre dispostos a envolverem-se, com o objetivo de demarcarem suas posições na estrutura social (distinção). Por maior que seja a autonomia do campo, o resultado dessas lutas nunca é completamente independente de fatores externos. Em outros termos, as relações de força (entre o velho e o novo) dependem do estado das lutas externas e do reforço que uns e outros possam encontrar fora do campo (BOURDIEU, 2003, p. 65).

Todo campo social, seja o campo científico, seja o campo artístico, o campo burocrático ou o campo político, tende a obter daqueles que nele entram uma relação com o campo, a que Bourdieu (2014, p. 140) chama de illusio. De acordo com o mencionado teórico, os agentes podem querer inverter as relações de força no campo, 
mas, por isso mesmo, reconhecem os alvos, não são indiferentes. Assim, para Bourdieu, querer fazer a revolução em um campo significa concordar com o essencial do que é tacitamente exigido por esse campo, a saber, que ele é importante, que o que está em jogo aí se torna tão importante a ponto de se desejar fazer a revolução.

\section{Agentes produtores}

Para Bourdieu, o agente é o ser que participa e pleiteia dentro do campo de interesses. $\mathrm{O}$ autor esclarece que os agentes obtêm o capital econômico e cultural de acordo com sua origem social, determinantes desde o seu nascimento. Ao transcorrer do tempo os agentes assimilam formas de agir dentro do meio social.

Conforme dados coletados e arquivados pelos projetos 'SempreViva' e 'Vida em Flor', os agentes, referidos na pesquisa ora relatada, são mulheres de baixa escolaridade e renda, cadastradas na Secretaria de Assistência Social de Joinville, que almejam, ao ingressar nos projetos de geração de renda da Univille, se qualificar para o mercado de trabalho, com vistas ao complemento da renda familiar. Trata-se de donas de casa casadas procedentes de cidades do interior de Santa Catarina e Paraná, que se dedicam aos afazeres domésticos e à educação dos filhos. Moradoras da periferia de Joinville, dominam determinadas técnicas artesanais, como crochê, bordado, fuxico ou patchwork. Algumas das integrantes vêm em busca de atividade que alivie a rotina doméstica, outras foram diagnosticadas com quadro de depressão. A partir da capacitação, nas oficinas dos projetos, passam a integrar o mercado de trabalho por meio de atividade empreendedora, autônoma ou vinculada a uma associação.

As agentes produtoras, supra-apresentadas, ao se cadastrarem na Secretaria de Assistência Social, passam a integrar os projetos de capacitação para a geração de trabalho e renda 'SempreViva', 'Vida 
em Flor' ou 'AmaViva', desenvolvidos na Univille.

O corpo docente, formado por professores do departamento de Design da Univille, transmite, nas oficinas de capacitação, conhecimentos relacionados à pesquisa, criação e desenvolvimento de artefatos. As atividades ocorrem uma vez por semana e contam com o auxílio de estudantes (bolsistas e voluntários principalmente da linha de formação em Moda) na preparação do espaço onde será realizada a oficina, disponibilização dos materiais utilizados, registro fotográfico e preparação do lanche.

\section{Financiadores}

Com o objetivo de contribuir com a formação do ser humano, para a melhoria do exercício profissional e desenvolvimento de uma sociedade mais justa e democrática, a Universidade da Região de Joinville, por meio de um fundo financiador próprio (Fundo de Apoio à Extensão [FAEX]), investe em atividades de Extensão Universitária. Por ano, 35 projetos de extensão são custeados. Para aprovação e implantação, os projetos são submetidos a um edital de demanda interna, sendo avaliados por dois membros internos e um membro externo à instituição.

Os projetos de geração de renda desenvolvidos pela Univille em parceria com a Secretaria de Assistência Social promovem, além da aprendizagem de conteúdos específicos, o desenvolvimento pessoal e a responsabilidade socioambiental e ética. As ações desses projetos, ao contribuírem com o aprimoramento profissional e consequente evolução das condições de vida familiar e local, investem na constituição de um futuro melhor aos menos favorecidos socialmente.

Considerando os agentes produtores e os financiadores, o tópico a seguir adentra em conceitos e define termos como 
artesanato, moda, cultura e identidade. Contextualiza o campo da Moda em Santa Catarina, aborda limites e hibridismo do campo da Moda e destaca o caráter multicultural do Estado.

\section{CONSIDERANDO OS SISTEMAS SIMBÓLICOS}

A investigação, aqui apresentada, investiu em conceituações e definições dos termos artesanato, moda e identidade cultural, analisados por meio de uma perspectiva sociológica.

De acordo com Bourdieu (2007), a ciência deve aplicar aos campos de estudo o princípio da teoria do conhecimento antropológico, segundo o qual os sistemas simbólicos que um grupo produz e reproduz no âmbito de um tipo determinado de relações sociais adquirem seu verdadeiro sentido quando referidos às relações de força que os tornam possíveis e socialmente necessários (BORDIEU, 2007, p. 176). Seguindo essa diretriz, é preciso evidenciar que os gostos (legitimados ou institucionalizados como tal) e as preferências estilísticas pelos artefatos produzidos e comercializados, em Joinville e em Santa Catarina, não são apenas um reflexo da estrutura social, como também um meio de afirmação e de adequação a uma vinculação social (CIPINIUK, 2014, p. 83).

\section{Artesanato, moda e identidade}

Para Cipiniuk (2006), faz-se necessário definir claramente o tipo de cultura que acarreta o artesanato e, sobretudo, não deixar de considerar que o povo que o produz participa do sistema integrado de comunicação dos mesmos valores, ouvem rádio e assistem televisão e, o mais importante, em sua maioria reside nas periferias e, mesmo morando longe, nas áreas antes denominadas rurais, têm íntimo contato com centros urbanos, ou seja, estão dentro do sistema 
capitalista. No entender de Cipiniuk (2006), o artesanato deve ser pensado juntamente com outro tipo de produção do mesmo sistema, e não algo contrário a ele. O diálogo entre design e artesanato passa pelo respeito a um tipo de cultura desprezada; trata-se de integrar as classes sociais e as suas diferentes culturas a um sistema que as separa.

\section{Identidade/hibridismo cultural}

Conforme documento elaborado pelo $\operatorname{SEBRAE}$ (2004, p. 18), desenvolver produtos artesanais de referência cultural significa valer-se de elementos que reportem o produto ao seu lugar de origem, como a utilização de certos materiais, insumos ou técnicas de produção típicas da região ou uso de elementos simbólicos que façam menção às origens de seus produtores ou de seus antepassados.

Compreendeu-se, no desdobrar da pesquisa, que é necessário, quando se almeja uma produção cultural híbrida, envolvendo Design e artesanato, considerar o contexto em meio aos quais as práticas são desenvolvidas. $E$, indo adiante, entendeu-se que tem de se levar em conta que a cultura local é constituída pelo empréstimo cultural de outras culturas (SAID apud BURKE, 2003, p. 13).

Entretanto, é relevante um posicionamento teórico no tocante ao entendimento do fenômeno (por alguns teóricos denominado hibridismo cultural - atacado por uns e defendido por outros - e por outros chamado com outros termos), evidenciando que, no encalço dos escritos de Burke (2003, p. 116), entendemos que as formas híbridas de hoje não são necessariamente um estágio no caminho para uma cultura global homogênea ou para uma desintegração cultural. Para Burke, a análise mais convincente de nossa cultura é aquela que vê uma nova ordem, surgindo uma formação de novos ecotipos, a cristalização de novas formas, a reconfiguração de culturas, a "crioulização do mundo" (BURKE, 2003, p. 116). 
No caso de Joinville/SC, o hibridismo cultural é facilmente percebido, já que a cidade se constitui, em grande parte, por pessoas provenientes de outras localidades. A própria constituição dos grupos que integram os projetos de geração de renda da Univille evidencia o caráter multicultural. Observa-se a necessidade de considerar tal hibridação na definição da identidade cultural do grupo de artesãs dos projetos.

Buscando-se uma resposta sociológica ao problema, destacado pela investigação, entendeu-se como necessário confrontarem-se as teorias de apoio com a prática dos grupos de geração de renda.

\section{Moda e sociedade}

Bourdieu (2011, p. 18) considera que certas maneiras de tratar as roupas e os enfeites, aqui transpostos para a terminologia design de moda, exprimem, de forma simbólica, fatores de distinção no meio social. De acordo com Bourdieu, entre todos os tipos de consumo e de conduta passíveis de abrigar uma função expressiva, quer se trate da compra de um automóvel, da decoração de um apartamento, quer se trate da escolha de uma escola para os filhos, são as roupas e os enfeites (em virtude de seu elevado rendimento simbólico), que, ao lado, da linguagem e da cultura, melhor realizam a função de socialização e dissociação.

Nos fundamentos da sociologia das formas simbólicas, Bourdieu (2002, p. 8) destaca que o poder simbólico se manifesta por meio de estruturas como a arte, a religião e a língua. O autor (BORDIEU, p. 1015) afirma que os símbolos, coordenados pelos sistemas simbólicos, têm como função preponderante a integração social, conferindo sentido ao mundo social e possibilitando o consenso a respeito da ordem estabelecida.

O poder simbólico, conforme Bourdieu (2002, p. 10-15), 
imperceptível e invisível, é uma forma transfigurada e legitimada das outras formas de poder. E o que torna possível tal poder é a cumplicidade daqueles que não querem saber que lhe estão sujeitos ou mesmo que o exercem, conclui o autor. Para o mencionado autor, a conversão do capital econômico em capital simbólico, mediante o desperdício de energia social, que é a condição da permanência da dominação, só pode ter sucesso com a cumplicidade de todo o grupo.

De acordo com Bourdieu (2011, p. 17-20), tudo se passa como se os sistemas simbólicos estivessem destinados pela lógica de seu funcionamento enquanto estrutura de homologias e de oposições, ou melhor, de desvios diferenciais, a preencher uma função social de socialização e dissociação ou, então, a exprimir os desvios diferenciais que definem a estrutura de uma sociedade, enquanto sistema de significações, arrancando os elementos constitutivos dessa estrutura, grupos ou indivíduos da insignificância.

Assim, o termo habitus, adotado por Bourdieu (THIRY-CHERQUES, 2006), para estabelecer a diferença entre conceitos correntes como hábito, costume, praxe, tradição, situa-se entre a estruturação e a ação. “Denota o sistema de disposições duráveis e transferíveis, que funciona como princípio gerador e organizador de práticas e de representações, associado a uma classe particular de condição de existência" (THIRYCHERQUES, 2006, p. 33). Ele funciona como um esquema de ação, percepção e reflexão. "Presente no corpo (gestos, posturas) e na mente (formas de ver, de classificar) da coletividade inscrita em um campo, automatiza as escolhas e as ações em um campo dado, 'economiza' o cálculo e a reflexão" (THIRY-CHERQUES, 2006, p. 34).

É interessante considerar o design de moda com base nas noções de campo e habitus de Bourdieu. De fator isolado, o design de moda passa a ser compreendido a partir de sua relação com os 
agentes produtores e consumidores. Estes são contemplados pela consideração do gosto vigente, moldado pelo habitus instituído socialmente.

\section{Design de moda, artesanato e territorialidade}

No tocante ao design de moda, Fletcher (2011, p. 108) ressalta a importância em fazer com que as prioridades locais sejam relevantes, com vistas a promover o desenvolvimento sustentável num processo potencialmente transformador, para fomentar a solidez econômica e, ao mesmo tempo, a diversidade cultural e estética.

Nesses termos, o reconhecimento do artesanato local somente será possível com iniciativas de projetos que viabilizem ações que valorizem o desenvolvimento sustentável do território, com o aproveitamento racional dos recursos naturais e a justa valorização do artesão.

\section{Limites e hibridismos no campo da moda}

Como referência fundamental acerca da temática 'hibridismo cultural', a investigação ora relatada foi consonante ao entendimento de Canclini (2011, p. 220). O autor observa que os fenômenos culturais folclóricos ou tradicionais são o produto multideterminado de agentes populares e hegemônicos, rurais e urbanos, locais, nacionais e transnacionais. Por extensão, de acordo com o referido teórico, é possível pensar que o popular é constituído por processos híbridos e complexos, usando como signos de identificação os elementos procedentes de diversas classes e nações.

Mostrou-se fundamental, para a manutenção da cultura dos agentes produtores, que se valorize a matéria-prima local. Considerou-se essencial, para a manutenção dos processos naturais do planeta, que se considere o meio ambiente no momento de 
escolha das matérias-primas, as quais devem ser renováveis, de acordo com as condições climáticas e geográficas do local em que ocorre a produção.

\section{Joinville: produção cultural e mercado}

Os habitus estabelecem as diferenças nas práticas dos agentes, ou de seus grupos, em meio ao campo (BOURDIEU, 2003, p. 21). Essas diferenças são constitutivas de sistemas simbólicos, configurandose em signos distintivos, propiciando o estabelecimento de diferenciadas categorias de percepção (BORDIEU, 2003, p. 22).

Evidenciaram-se a rica história da imigração de Joinville e a herança cultural que os imigrantes trouxeram, marcada pelo hibridismo cultural. Destacaram-se como perceptível, ainda hoje, especialidades gastronômicas - com pratos genuinamente joinvilense - e artesanais com peças bordadas manualmente. Destacou-se, ao longo da pesquisa, que Joinville possui um moderno centro urbano e industrial, mas que contém traços típicos com jardins floridos e casas no estilo enxaimel.

Considerando-se os dados coletados e levando em conta as bases teóricas de Bourdieu, práticas diferenciadas, focadas na capacitação para o trabalho, foram realizadas nos projetos Vida em Flor e SempreViva no fim do segundo semestre de 2013 e ao longo do ano de 2014. Esse é o mote do próximo capítulo. 


\section{APLICANDO A TEORIA NA PRÁTICA}

A investigação, referida neste artigo, destacou a relevância de estabelecer-se uma relação social recíproca entre Design e artesanato. Não vislumbrou dois segmentos opositores, nem tampouco entendeu que o desenvolvimento moderno, com a evolução do saber culto do Design, tenha suprimido ou venha a suprimir as culturas populares tradicionais.

A pesquisa prática foi realizada em dois grupos específicos: Projeto Geração de Renda: Grupo Vida em Flor e Geração de Renda: Grupo SempreViva.

\section{Experiência prática nos dois anos de desenvolvimento da pesquisa de mestrado}

Discorre-se a seguir acerca do processo de desenvolvimento de novos artefatos, integrando-seferramentas e tecnologias acadêmicas, do campo do design de moda, com os conhecimentos populares de técnicas, processos e materiais locais, compreendendo em tais práticas a relevância de estabelecer uma relação social recíproca.

\section{Projeto SempreViva desenvolvido em 2013 e 2014}

Considerando-se a realidade migratória, característica do grupo SempreViva, e procurando-se valorizar a cidade em que vivem, foi realizado em sala de aula, em 2013, um mapa mental sobre qual característica principal Joinville passa para cada integrante. As características mais citadas foram: florida, chuvosa, quente, hospitaleira, com muita vegetação, rios e baía, perto da praia. Propôs-se, então, uma pesquisa acerca das plantas encontradas nas residências das participantes. 
Com base em todas as considerações levantadas, o grupo foi desafiado a propor um projeto coerente com a pesquisa das características abordadas sobre Joinville. A escolha do artefato deu-se a partir do levantamento das habilidades técnicas das agentes produtoras (havia uma chapeleira no grupo), características geográficas da cidade, bem como materiais disponíveis. Decidiu-se projetar um acessório, chapéu, para proteção contra os raios solares, contemplando um público feminino que resida ou visite a cidade em direção às praias. As peças foram serigrafadas de forma artesanal com galhos e folhas inspiradas na vegetação trazida das suas residências e customizadas com fuxicos e bordados, em cores inspiradas nas flores encontradas nos jardins, como margaridas, girassóis, orquídeas e ipês.

$\mathrm{Na}$ turma de 2014, conforme levantamento, significativo percentual veio de outras cidades. Algumas nasceram em Joinville e outras vieram de cidades desenvolvidas do interior de Santa Catarina. Assim, foram apontadas, em sala, as principais características conhecidas pelas integrantes sobre a cidade que escolheram para morar: uma cidade tranquila, hospitaleira e com oportunidades de empregos e estudo. Como no ano anterior, a principal característica observada na oficina de linguagem visual foi a vegetação presente em Joinville, visto que a maioria mora em residências com espaço para quintais e hortas.

Como o projeto foi idealizado próximo ao verão, optou-se em projetar uma bolsa funcional que protegesse os produtos, como toalhas e protetor solar; projetou-se, em meio à oficina do projeto, a possibilidade de desenvolvimento de produtos cuja matéria-prima principal fosse banners descartados pela Univille.

No processo do reaproveitamento dos banners, notou-se que os bastões de madeira e as ponteiras seriam descartados. A proposta, por parte das integrantes, foi reutilizar esses suportes como alças, 
conforme projeto preliminar. As ponteiras plásticas, por sua vez, serviram como acabamento das alças de madeira. Outro material que acompanha os banners são os cordões para pendurá-los. A proposta, diante desse material, foi utilizá-lo acompanhado por um mosquetão como porta-chaves.

\section{Projeto Vida em Flor desenvolvido em 2013 e 2014}

O projeto foi constituído por mulheres oriundas de cidades do interior do Paraná e Santa Catarina que residem no bairro Ulisses Guimarães, propriamente no Loteamento Jardim Loureiro, área de terra invadida, próxima do mangue e em processo de regularização dos lotes.

Preliminarmente, incentivou-se em sala de aula que os integrantes falassem sobre o local em que moram. Foram montados mapas mentais com as principais características do bairro e quais técnicas artesanais eram de conhecimento ou domínio do grupo. Em seguida, nas dependências da Univille, os integrantes puderam trocar informações e experiências acerca do local onde vivem. Num primeiro momento, com material visual, puderam conhecer a geografia e história do bairro. Percebendo-se o quanto o local onde habitam é envolvido por manguezais que abrigam rica representação da fauna e flora de nossa região.

Com o encerramento do segundo semestre das atividades do projeto Vida em Flor, realizado em 2013, nova turma foi formada no primeiro semestre de 2014, com remanescentes e novos integrantes do Loteamento Jardim Loureiro. Nas oficinas, com foco na modelagem e costura, confeccionaram-se novas peças de vestuário, com foco na cidade de Joinville.

O projeto Vida em Flor investiu no desenvolvimento de vestuário representativo dos elementos visuais locais (linhas, formas, 
cores e texturas). Em sua execução, saberes relativos ao campo do design de moda (modelagem, costura e estamparia) evidenciaram o desenvolvimento amigável do processo produtivo, investindo na aplicação de tintas naturais, extraídas de vegetais encontrados pelos integrantes no próprio bairro, e priorizando a valorização dos produtos por meio de aplicação de técnicas artesanais manuais, nas "sobras" de tecidos retiradas no corte da peça do vestuário.

As peças foram customizadas, pois cada integrante optou por técnicas ancoradas em habilidades manuais individuais, como fuxico, macramê e patchcolagem. A técnica de macramê (representativa das redes de pesca) foi obtida por meio do tingimento natural do açafrão. As flores de fuxico e canoa de patchcolagem foram confeccionadas a partir das sobras dos tecidos tingidos com açafrão e urucum.

\section{CONCLUSÃO}

A investigação 'design de moda e artesanato: uma relação social recíproca', apresentada ao longo deste artigo, objetivou verificar a contribuição dos estudos fundados na abordagem social, para o campo do design de moda, visando aplicabilidade com projetos que visam geração de trabalho e renda, por meio de processos artesanais. O estudo identificou e analisou potencialidades de colaboração entre professores e estudantes de Design e grupos femininos, integrantes de projetos de extensão universitária, primando pela integração de ferramentas e tecnologias acadêmicas com conhecimentos populares de técnicas, processos e materiais locais.

O desenvolvimento da pesquisa, apoiada na teoria dos sistemas simbólicos de Pierre Bourdieu, destacou a relevância de estabelecerse uma relação social recíproca, marcada pelo hibridismo cultural, entre designers e artesãos. Investindo na conceituação do campo 
do design de moda, pelo viés sociológico, contextualizou as práticas de designers de moda em Santa Catarina e destacou o caráter multicultural do Estado. Nesse processo, enfatizou a produção cultural e mercado local da cidade de Joinville, onde os agentes produtores estão inseridos.

A pesquisa foi aplicada aos projetos de geração de renda 'SempreViva' e 'Vida em Flor'. Esses projetos, destinados a um público feminino-na grande maioria constituído por mulheres de baixa renda, cadastradas na Secretaria de Assistência Social de Joinville-são vinculados ao departamento de Design da Universidade da Região de Joinville (Univille) e desenvolvidos pela Extensão Universitária.

Evidenciaram-se a história da imigração de Joinville e a herança cultural que os imigrantes trouxeram, marcada pelo hibridismo cultural. Sobre Joinville, ressaltou-se o intenso processo de crescimento populacional referente à contínua migração de pessoas em busca de trabalho. Diante da pesquisa pode-se constatar o apreço com que são cuidados os jardins presentes nas residências das integrantes do projeto 'SempreViva', no qual aproximadamente $65 \%$ das residências são próprias. Diferentemente das participantes do projeto 'Vida em Flor', em que as casas simples possuem terrenos com pouca vegetação, por consistir num local de invasão, sem documentação e com pouca infraestrutura.

Propondo-se novos usos e composições para os banners descartados pela Univille, foi confeccionada pelo projeto'SempreViva', em 2014, bolsas utilizando-se de todos os materiais que compõem o artefato. Além das lonas, também os bastões de madeira, ponteiras plásticas e cordões de nylon foram utilizados na confecção das peças. Integrou-se a consciência ambiental, no uso de banners que seriam descartados, com o fazer manual, na customização das bolsas com detalhes em crochê e o patchwork. 
O método, aplicado nas oficinas, excedeu as aplicações metodológicas disseminadas nos cursos de Design, observandose a vivência dos agentes produtores, sua história e sua cultura. Destacou-se, desse modo, o valor dos saberes dos artesãos e dos designers de moda (saber popular e saber científico), promovendo o desenvolvimento sustentado, por meio de considerações ao meio ambiente na definição de técnicas, manejos e materiais usados.

A aproximação dos estudantes, bolsistas e voluntários, que acompanharam os projetos, propiciou a constituição de novos saberes relacionados a técnicas utilizadas para a confecção de artefatos, acessórios e vestimentas. A partir do trabalho colaborativo, com a troca de conhecimento e informações entre bolsistas, professores, colaboradores e integrantes dos projetos, propôs-se um olhar diferenciado aos futuros profissionais da área de Design, vindo ao encontro dos valores e princípios da Extensão Universitária da Univille: possibilitar o aprendizado ultrapassando os espaços acadêmicos, aproximando o conhecimento científico e o conhecimento popular.

Por meio da abordagem social foi possível perceber a determinação e a força das integrantes dos projetos de geração de renda da Univille, que investem esforços para expandir seu horizonte de saberes e, consequentemente, ampliar a renda familiar e melhorar a qualidade de vida. 


\section{REFERÊNCIAS}

BORGES, A. Design + Artesanato: o caminho brasileiro. São Paulo: Terceiro Nome, 2011.

BOURDIEU, P. A economia das trocas simbólicas. São Paulo: Perspectiva, 2007.

. A economia das trocas simbólicas. São Paulo: Perspectiva, 2011.

. O amor pela arte. São Paulo: EDUSP, 2007.

. O poder simbólico. Rio de Janeiro: Bertrand Brasil, 2002.

. Razões práticas sobre a teoria da ação. São Paulo: Papirus, 2003-2014.

. Sobre a televisão. Rio de Janeiro: Jorge Zahar, 1997.

CANCLINI, N. G. Culturas híbridas: estratégias para entrar e sair da modernidade. 4. ed. São Paulo: EDUSP, 2011.

\section{Complementares}

BURKE, P. Hibridismo cultural. São Leopoldo: UNISINOS, 2003.

CIPINIUK, A. Design e artesanato: aproximações, métodos e justificativas. In: CONGRESSO BRASILEIRO DE PESQUISA E DESENVOLVIMENTO EM DESIGN, 7., 2006, Paraná.

- Design: o livro dos porquês - o campo do design compreendido como produção social. Rio de Janeiro: Reflexão, 2014.

FLETCHER, K. Moda \& Sustentabilidade: design para mudança. São Paulo: SENAC, 2011. 
SEBRAE. Programa Sebrae de artesanato: termo de referência. 2004.

THIRY-CHERQUES, H. R. Pierre Bourdieu: a teoria na prática. Rio de Janeiro, 2006.

UNIVILLE - UNIVERSIDADE DA REGIÃO DE JOINVILLE. Área de Extensão Universitária. Disponível em: $<$ http://novo.univille.edu.br/ pt-BR/a-univille/proreitorias/proex/area-extensao/index/597362>. Acesso em: 24 set. 2014. 



\section{Desenvolvimento de produtos a partir do reúso de materiais metálicos descartados}

Sidnei Luiz Zamberlan (Currículo Lattes) Anna Luiza Moraes de Sá Cavalcanti (Currículo Lattes)

\section{INTRODUÇÃO}

A pesquisa de Mestrado Profissional em Design, intitulada 'Desenvolvimento de produtos a partir do reúso de materiais metálicos descartados', propôs uma investigação acerca dos resíduos industriais passíveis de reúso e sua ressignificação com o olhar do design.

Anecessidade de propor soluções para os resíduos provenientes de diferentes segmentos do setor produtivo e a falta de alternativas sustentáveis que proporcionem o reúso desses materiais, levou ao estudo da relação entre o uso prescrito e o uso real de um artefato, que muitas vezes pode ser mudada, tanto pelo usuário como pelos 
designers. A indagação que norteou a pesquisa foi sobre quais seriam os resíduos da produção industrial na região de Joinville passíveis de reaproveitamento no desenvolvimento de novos produtos e como o design poderia contribuir para a valorização desses recursos de forma sustentável?

A investigação objetivou apresentar um conjunto de considerações que possibilitasse o desenvolvimento de um produto que atendesse a necessidades específicas dos usuários, as quais foram identificadas nas regiões de clima frio no Sul do Brasil, direcionando ao desenvolvimento de um sistema para cocção, calefação e aquecimento de água.

Esse sistema destinou-se, primeiramente, a pesquisadores e estudantes das áreas de Design, como forma provocativa ao estudo de alternativas ambientalmente amigáveis, no que diz respeito ao reaproveitamento de resíduos e no estudo dos ciclos de vida dos produtos. Em segundo plano, disponibilizou-se o projeto a dois grupos específicos de possíveis usuários: 1) usuários com recursos limitados e/ou dificuldade de acessar novas tecnologias; 2) apreciadores de soluções ecossustentáveis.

Os fundamentos da pesquisa apoiaram-se nos conceitos do Design para a sustentabilidade. Para a intervenção prática, foram utilizadas metodologias projetuais do campo do design e engenharia de produção, considerando redução de custos de fabricação e otimização dos processos, a fim de propor uma solução viável.

Como resultado obteve-se uma proposta de um produto/ protótipo documentado por meio de um memorial descritivo, que registrou o passo a passo da construção dos elementos e da montagem do sistema. Esses registros foram disponibilizados, por meio de ambiente online (http://meureuso.blogspot.com.br/), a pesquisadores e comunidade. 
Este artigo apresenta as principais etapas desenvolvidas no mencionado projeto: contextualização teórica acerca do desenvolvimento sustentável no campo do design; levantamento e estudos construtivos para o desenvolvimento do protótipo; as análises ergonômicas e os principais resultados da investigação.

\section{CONTEXTUALIZAÇÃO TEÓRICA ACERCA DO DESENVOLVIMENTO SUSTENTÁVEL NO CAMPO DO DESIGN}

Dados registrados pela Agência Brasileira de Desenvolvimento Industrial (ABDI), destacam que uma nova fase da indústria no Brasil se fez a partir de 1990, quando foi criada a "Política de Competitividade", possibilitando, assim, a entrada de novas tecnologias no país. Com fim do monopólio em alguns setores da indústria brasileira, iniciou-se uma nova fase na fabricação de bens, em que as ofertas e variedades de produtos provocaram também o aumento de resíduos gerados. Paralelamente a isso, surgiram os primeiros indícios da obsolescência precoce dos equipamentos e produtos, resultados da concorrência.

Baxter (2000) argumenta que, com os lançamentos dos produtos globalizados, os produtos com vida média cada vez mais curta se espalhariam por todos os lados, provocando uma desordem no controle de resíduos provenientes dos países industrializados.

Somente em 2010, duas décadas depois da Política de Competitividade, o governo federal aprovou uma Política Nacional de Resíduos Sólidos (PNRS), com o intuito de disciplinar a gestão e o gerenciamento dos resíduos sólidos no país. Por meio do Decreto de Lei 7.404, regulamentado em 23 de dezembro de 2010, a Lei obriga os fabricantes, importadores, distribuidores, comerciantes e usuários a estruturarem e implementarem sistemas que permitam a coleta, separação e destinação final adequada dos resíduos sólidos, 
viabilizando o manejo e reaproveitamento dos resíduos em seu ciclo de vida ou em outros ciclos produtivos até sua destinação final.

Atualmente, em algumas cidades, os resíduos sólidos provenientes do setor industrial e doméstico são direcionados para empresas classificadoras, para posteriormente serem reutilizados, reciclados ou incinerados, como mostra a Figura1.

Figura 1 - Resíduos de produtos descartados
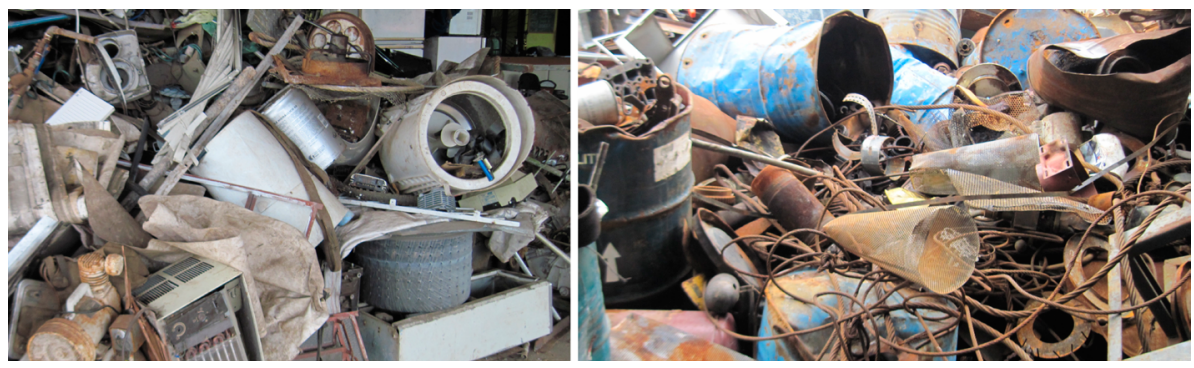

Fonte: arquivo pessoal

No tocante às questões de reúso e reorganização dos componentes (peças e elementos), vale destacar as reflexões de Manzini (2010) a respeito das possibilidades de produtos projetados com uma visão sustentável em sua essência, verticalizando as ações numa forma descendente, para recursos menos 'sintéticos', possibilitando soluções de caráter renovável.

Segundo Kasper (2009), “a representação de um usuário dotado de necessidades específicas continua orientando o trabalho de projeto, que se esforça em otimizar sua relação - predefinida com o artefato." Porém, a relação entre o uso prescrito e o uso real de um artefato, muitas vezes, pode ser mudada, tanto pelo usuário como pelos designers, na medida em que concebem novos produtos a partir de produtos existentes, fazendo reúso dos elementos. 
Projetar produtos sustentáveis requer um pensamento sistêmico aplicado aos projetos de produtos e suas funções. Concebelos, projetá-los e utilizá-los da melhor maneira possível deveriam ser uma responsabilidade implícita em qualquer segmento preocupado com a eficácia de seus projetos.

De acordo com Manzini (2010), o controle do impacto ambiental provocado pelas atividades humanas depende de três variáveis: (1) a população; (2) a procura do bem-estar; (3) a ecoeficiência das tecnologias aplicadas. Considerando as variáveis relacionadas ao crescimento das populações dos países em desenvolvimento, a perspectiva de sustentabilidade é um fator discordante em relação aos modelos de desenvolvimento econômico.

Vieira e Litz (ECO21, 2014) destacam que em todos os países em desenvolvimento a prioridade governamental deve ser fundamentada no crescimento econômico quantitativo e que qualquer movimento contrário ao progresso transforma-se num entrave ao desenvolvimento, inclusive a preocupação com o meio ambiente.

Não é suficiente pensar em desenvolvimento sustentável simplesmente apresentando considerações envolvendo a satisfação e qualidade de vida da população, mas, sobretudo, que haja uma preocupação com os recursos renováveis/sustentáveis; caso contrário, haverá gerações herdando um planeta coberto de resíduos e sucatas. Os beneficiários do desenfreado crescimento não serão diretamente atingidos, mas deixarão uma herança indesejada, muitas vezes não ostentada pelos consumidores, como demonstra a Figura 2 a seguir, em que se observa na sequência das imagens, uma infinidade de materiais, formas, dimensões e estados de preservação dos artefatos descartados, muitas vezes em depósitos inadequados. 
Figura 2 - Resíduos variados provenientes de descartes
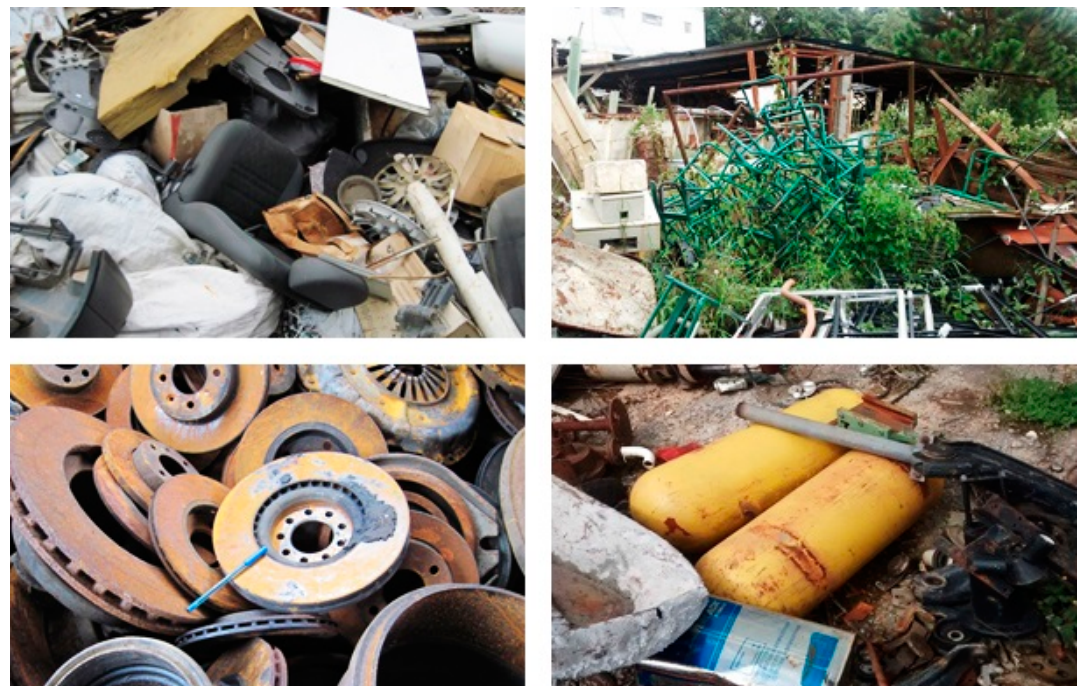

Fonte: arquivo pessoal

Faz-se necessário priorizar pesquisas que invistam na minimização de recursos e na eficiência prolongada dos produtos, por meio de políticas que considerem o meio ambiente e implantar um sistema de desenvolvimento sustentável no qual as necessidades dos usuários sejam conhecidas e investigadas.

Segundo Manzini (2010), essa abordagem provoca o envolvimento dos indivíduos que se beneficiam no processo de integração e difusão dos conceitos da sustentabilidade aos serviços de um produto/conceito, passando a agir em favor de estudos e estratégias concernentes a eficiências minimistas de recursos aplicando inteligências sustentáveis. O citado autor faz algumas considerações acerca da expectativa de sustentabilidade em nível mundial, onde nas próximas décadas deveremos ser capazes de viver melhor consumindo menos, reduzindo a produção de bens e fazendo com que o bem-estar seja possível pelo consumo reduzido e consciente dos produtos e materiais. 
A partir dessa linha, as percepções de necessidades devem ser consideradas como fatores de decisão na utilização de recursos e tecnologias, não se preocupando com o crescimento desenfreado, mas sim com as necessidades básicas supridas, utilizando o mínimo de recursos, preferencialmente renováveis.

Uma das diretrizes no tocante à minimização de processos construtivos está no estudo apresentado por Manzini (2010) acerca dos conceitos de Design for Disassembly (DFD). Conforme proposições do DFD, os produtos devem ser desenvolvidos adotando o princípio de desmembramento dos elementos, facilitando, assim, a montagem e desmontagem dos componentes.

Para as práticas construtivas, que objetivam conceber e projetar produtos facilitando sua desmontagem, Manzini cita outra teoria, que pode complementar os princípios apresentados pelo DFD. O Design for Assembly (DFA) (Amaral et al., 2006) é uma abordagem técnica que avalia o todo de um produto, analisando as possibilidades de simplificação da estrutura, sem alterar o uso e a funcionalidade dos componentes. O projeto para montagem avalia todo o produto, não só as peças individualmente, em que sua estruturação aborda as racionalidades operacionais para a concepção de um produto, procurando o mais eficiente uso das funções dos componentes: simplificando produtos com redução de componentes (considerando estimativas de custos); propondo procedimento sistemático (pelo ponto de vista da montagem); e reduzindo os custos gerais da concepção do sistema, independentemente das quantidades produzidas (manufatura, mão de obra etc).

O desenvolvimento de um produto nesses moldes, proporciona aos pesquisadores uma imersão no contexto do descarte e suas diferentes justificativas quanto à geração de resíduos, proporcionando sensações e experiências diferenciadas em termos 
de tempo, dedicação e compreensão dos contextos aplicados a um projeto.

\section{LEVANTAMENTO PARA O DESENVOLVIMENTO DO PROTÓTIPO}

Com base na problematização, algumas indagações foram postas como elementos da pesquisa. Entre elas, quais seriam os principais resíduos passíveis de reaproveitamento no desenvolvimento de novos produtos e como o Design poderia contribuir para a valorização desses recursos de forma sustentável?

Sob a ótica do design, o reaproveitamento do resíduo industrial pode transformá-lo em novos produtos com características particulares, inovadoras, promovendo inclusive a redução do descarte.

$\mathrm{Na}$ pesquisa foram estabelecidas algumas metas em que, no andamento do processo e de acordo com a sua realização, ressaltaram-se algumas informações relevantes: a identificação de empresas geradoras e/ou recicladoras de resíduos metálicos; a classificação e análise dos tipos de materiais que poderiam ser utilizados; o levantamento das tecnologias e processos de fabricação necessários; a construção de um protótipo baseado nas informações obtidas; e a realização dos testes de funcionamento desse protótipo, analisando dados para validações dos resultados e adequando o modelo no decorrer dos estudos.

Dentre as empresas que apoiaram o projeto, destacaram-se as que produzem resíduos metálicos da produção manufaturada em uma empresa da região (Figura 3). 
Figura 3 - Resíduos metálicos e não metálicos - Carrocerias Palmeira
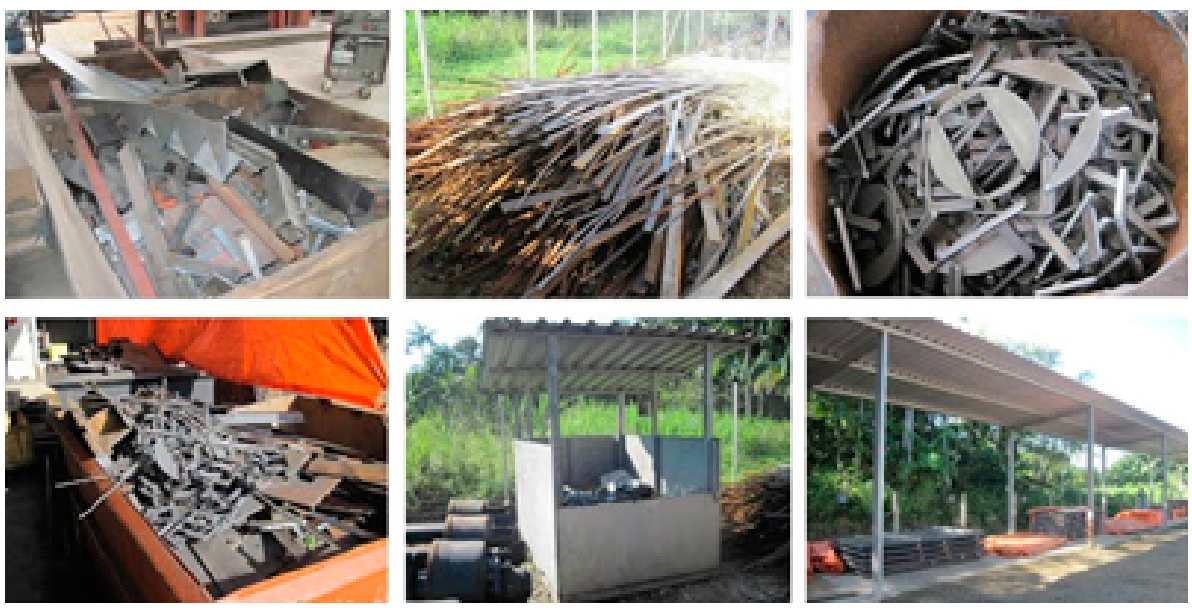

Fonte: arquivo pessoal

Nas empresas investigadas, percebeu-se uma preocupação quanto à separação dos resíduos de acordo com sua tipologia, adotando como solução imediata o repasse para empresas especializadas no recolhimento e classificação de materiais descartados.

Dos resíduos provenientes das empresas classificadoras, os que chamaram a atenção durante a pesquisa de campo foram os produtos descartados com vida útil inferior a 10 anos de fabricação, principalmente porque o descarte é ocasionado por elementos construtivos que geram a dependência dos demais componentes preservados dos produtos (Figura 4). 
Figura 4 - Resíduos precoces
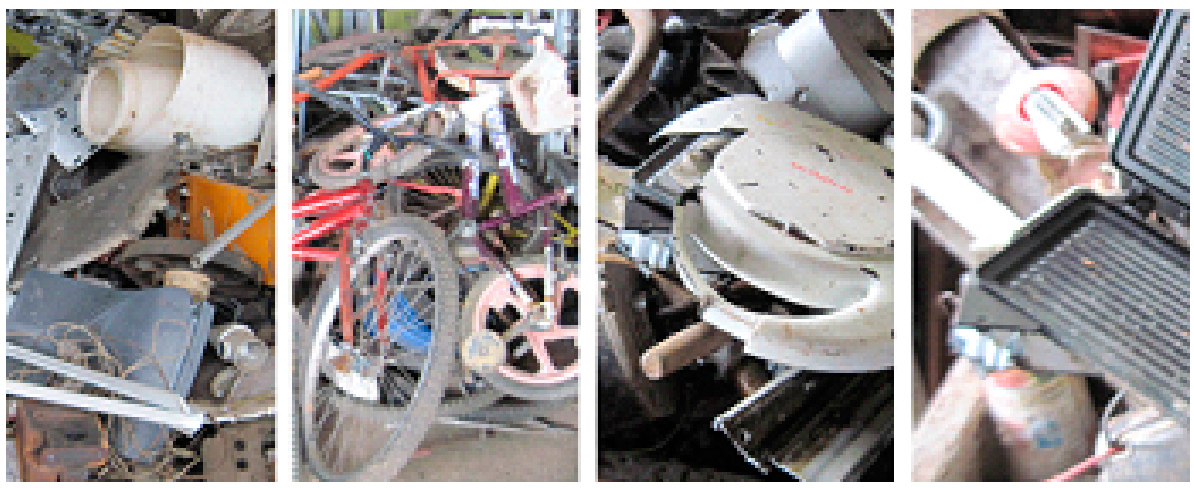

Fonte: arquivo pessoal

Manzini (2010) destaca que se conseguirmos prolongar a vida útil de um material/objeto, retardando sua possível desmaterialização e proporcionando a extensão do seu ciclo de vida (que é uma das abordagens estratégicas de produtos com requisitos ambientais), reduziremos significativamente os custos e insumos utilizados na rematerialização e, como consequência, contribuiremos para o avanço da ecologia industrial.

A partir da identificação de materiais provenientes de reúso passíveis de aplicação com tecnologias relativamente simples, encontrou-se o aporte determinante para a escolha do elemento selecionado para o desenvolvimento da proposta do produto, no caso o tambor de freio de veículos rodoviários, como mostra a Figura 5. 
Figura 5 - Elemento selecionado para o desenvolvimento de um produto

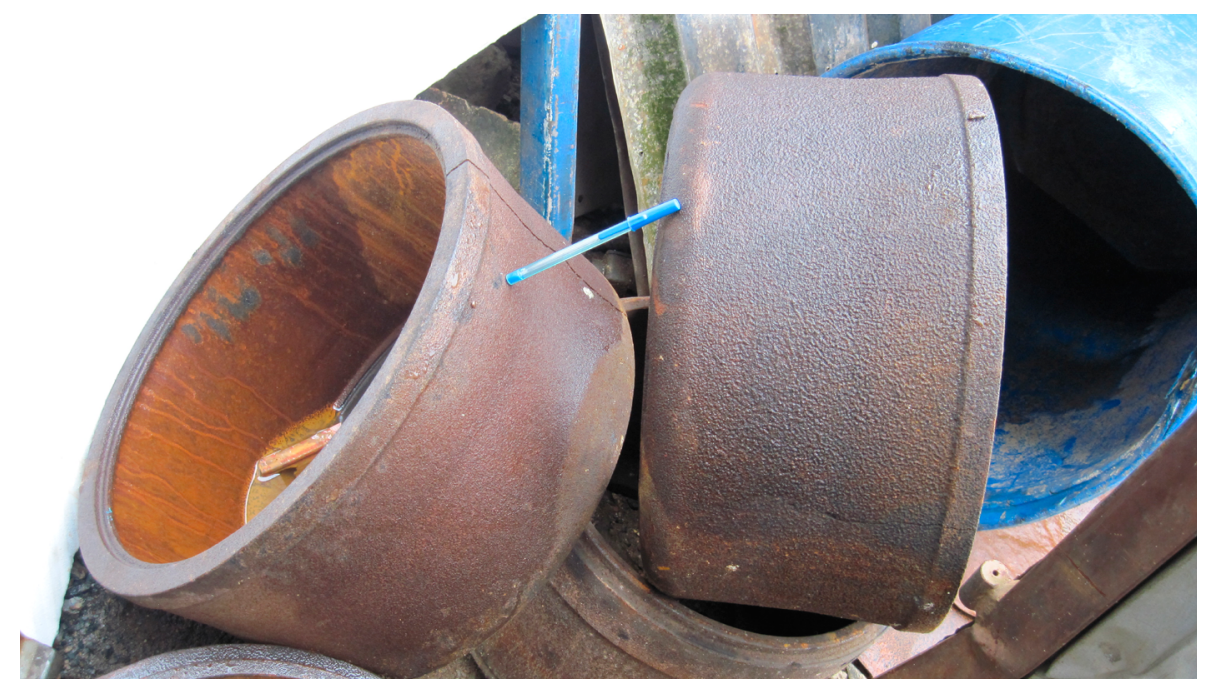

Fonte: arquivo pessoal

A vida útil de um tambor de freio, utilizado no conjunto estrutural dos rodados de veículos rodoviários, é consideravelmente curta, gerando volume significativo desse resíduo a cada troca. De acordo com dados do IBGE, fornecidos pelo Departamento Nacional de Trânsito (DENATRAN) o Brasil possuía em 2013 uma frota de 2.488.680 caminhões e 547.565 ônibus no país.

Considerando as trocas necessárias, observa-se que o volume desse resíduo é significativo e, nesse sentido, foi percebido como um potencial artefato para o estudo relacionado acerca de materiais passíveis de reúso.

A partir das definições quanto ao tipo de resíduo que foi selecionado para o desenvolvimento do produto, iniciaram-se os contatos com as empresas que possuíam os componentes necessários para o andamento do projeto. Dos materiais recebidos na doação, os tambores de freio e os aros de veículos rodoviários foram disponibilizados pela empresa Transtusa S.A. (Figura 6). 
Figura 6 - Tambores de freio e aros doados pela Transtusa S.A.

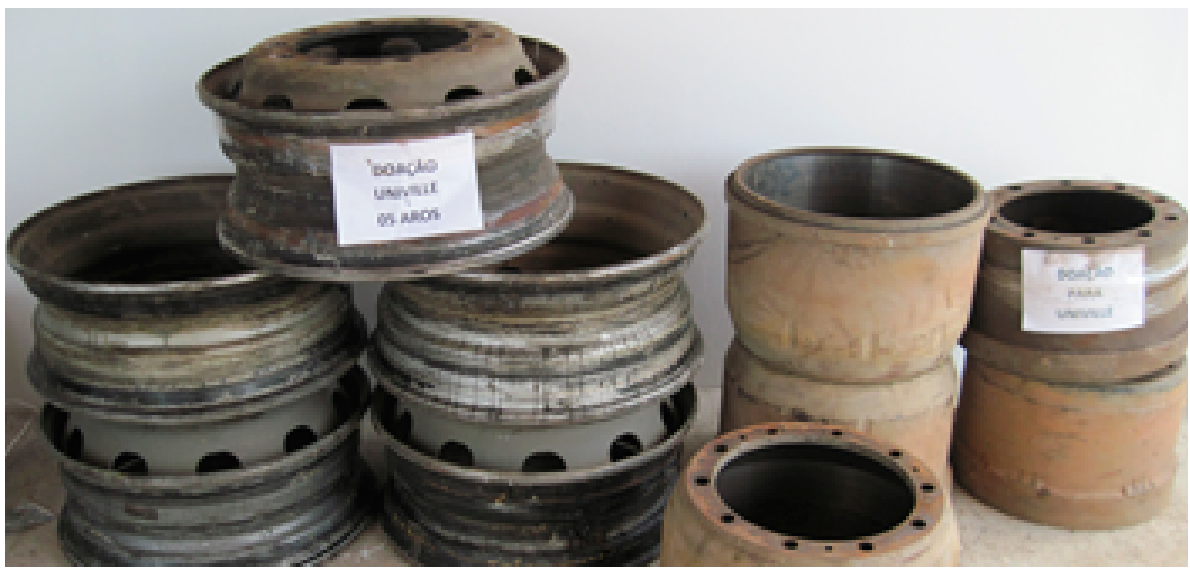

Fonte: arquivo pessoal

A proposta de reutilização desse artefato foi percebida a partir de uma experiência anterior do acadêmico utilizando-o para a cocção. Observando o potencial de exploração e ressignificação desse objeto, o estudo foi direcionado à verificação das possibilidades construtivas para o desenvolvimento de um sistema de cocção, calefação e aquecimento de água que atendesse a uma demanda específica identificada na região Sul do Brasil, onde as temperaturas sofrem variações significativas.

Das informações levantadas na identificação dos resíduos e na seleção do objeto da pesquisa, foram examinadas diferentes plataformas (sites, blogs e revistas eletrônicas) para identificar sistemas existentes que utilizassem os mesmos componentes e em diferentes concepções, sendo encontrados fogões similares, concebidos de forma simples e eficiente, porém em sites estrangeiros, cujas regiões climáticas são favoráveis ao uso de sistemas de cocção e calefação. Foram localizados produtos que apresentavam diversas alternativas de reúso, inclusive componentes metálicos como vergalhões de ferro, aros de rodados de caminhão, tambores de 
óleo e tubulações em geral. Curiosamente, durante as pesquisas não foram encontradas propostas de aquecimento de água adaptadas aos conjuntos, somente sistemas de cocção e calefação.

Dados das Centrais Elétricas de Santa Catarina (Celesc S.A.) estimam que existam quase 200 mil residências no Estado que possuem fogões a lenha (CELESC, 2014). Porém, pode-se considerar que grande parte das casas nos municípios localizados nas regiões altas dos estados do Rio Grande do Sul e Santa Catarina e na parte sul do estado do Paraná está delimitada na mesma localização demográfica.

Considerando os hábitos dos usuários de fogão a lenha nas regiões do Planalto Serrano do Sul do país, observa-se que os fogões desempenham outras funções além das específicas (Figura 7).

Figura 7 - Fogões a lenha e suas funções
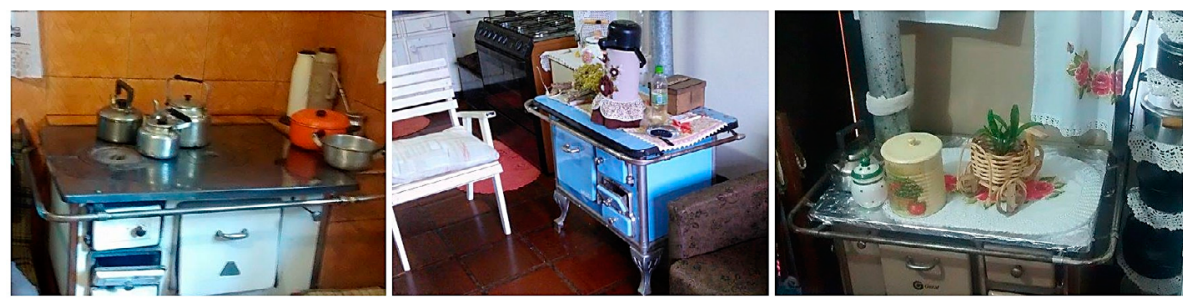

Fonte: arquivo pessoal

Acredita-se que as atribuições de novas funções aos objetos, de modo geral, são involuntárias, sem perceber que o uso real acaba sendo complementado por diferentes maneiras e contextos.

Quanto às relações de uso dos artefatos, primeiramente deve-se analisar as necessidades primárias a serem supridas para posteriormente aprofundar-se no desenvolvimento de concepções que superem as existentes, complementando-as ou substituindo-as com atributos que ofereçam vantagens ou sensações significativas no uso, além dos valores emocionais. 
A pesquisa, além de desenvolver um sistema com conceitos ambientalmente amigáveis, seguiu as linhas de referências apresentadas por Manzini (2010), destacando que além dos produtos realizarem as funções para as quais foram concebidas deveriam ser de fácil desmontagem e que proporcionassem a viabilidade de separação dos componentes, de acordo com seus respectivos materiais. Segundo o autor, para minimizar e facilitar o processo e as operações de desmontagem, as indicações que deve-se seguir dizem respeito à estrutura geral do produto, à forma dos seus componentes, bem como à forma e acessibilidade dos componentes de junção.

Ao pensar nas possibilidades de manufaturabilidade, optou-se pela concepção de um protótipo construído por meio de tecnologias de base (sistemas convencionais de transformação), acessíveis para a fabricação, considerando as limitações de recursos em virtude de fatores geográficos ou tecnológicos.

\section{ESTUDOS CONCEITUAIS E CONSTRUTIVOS}

A partir da identificação e seleção dos resíduos a serem utilizados na construção do protótipo do sistema de cocção, calefação e aquecimento de água, deu-se início aos estudos conceituais e construtivos, com a realização de diversos testes funcionais, nos quais, em diferentes configurações, analisou-se as melhores estratégias para a construção, a montagem/desmontagem, fabricação dos subconjuntos; configurações de montagem do sistema pelos usuários.

Com a definição de como seria disposto o corpo principal do conjunto, foram concebidos os elementos periféricos, valendo-se de materiais descartados provenientes de reúso, adquiridos com empresas classificadoras de resíduos metálicos (Figura 88). Entre os 
materiais utilizados no desenvolvimento do protótipo, grande parte foi comprada em empresas de reciclagem de materiais metálicos.

Figura 8 - Materiais utilizados na confecção do protótipo
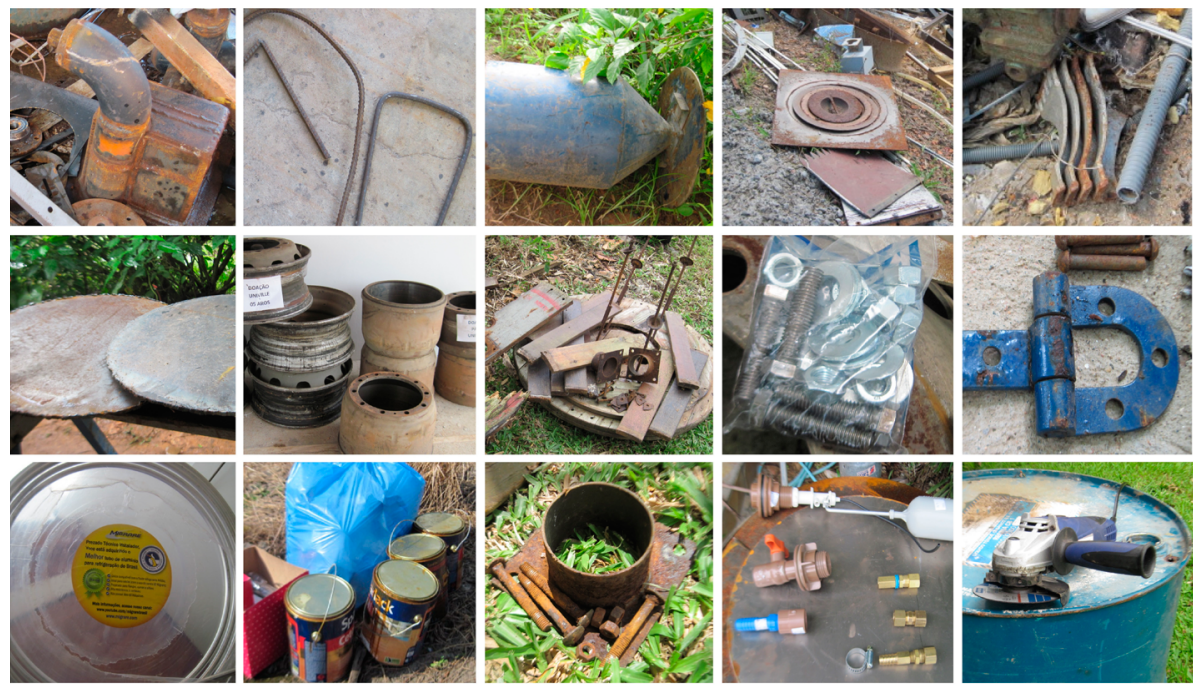

Fonte: arquivo pessoal

Elementos como a serpentina de alumínio, parafusos de fixação de componentes, sistema hidráulico e todos os consumíveis utilizados para a fabricação do protótipo foram comprados pelos pesquisadores totalizando um investimento de aproximadamente $\mathrm{R} \$ 960,00$. Os custos apresentados possibilitam que pesquisadores, ou até mesmo usuários em geral, tenham um parâmetro de investimento, caso haja interesse em construírem um produto similar ao apresentado. $\mathrm{Na}$ confecção do protótipo foram utilizadas ferramentas, máquinas e equipamentos de uso portátil, como punções de bico, brocas de aço rápido, furadeiras, esmerilhadeiras e lixadeiras.

A Figura 9, a seguir, representa a estrutura do sistema com as dimensões aproximadas dos componentes, desenhadas no software SolidWorks. A montagem do conjunto considera os componentes 
selecionados para a configuração final, compreendendo os seguintes componentes: (1) suporte cocção, (2) suporte utensílios, (3) câmera de combustão e (4) pés.

Figura 9 - Representação do conjunto

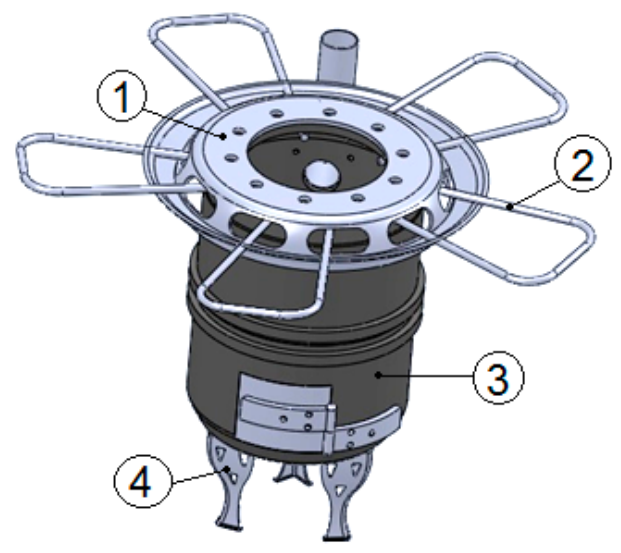

Fonte: arquivo pessoal

Para realização da modelagem virtual do sistema, foram medidas as peças já existentes e modeladas em software 3D para representar todo o conjunto, permitindo uma visão do protótipo final.

A partir da construção do reservatório, o sistema foi montado para o teste do conjunto completo com as funções de cocção, calefação e aquecimento de água. Pela análise final dos testes, comprovou-se que as atividades de cocção e calefação atenderam plenamente a suas funções em praticamente todos os testes.

Quanto ao sistema de aquecimento de água, foram realizados diversos testes para determinar a melhor configuração de montagem, que apresentaram um resultado com aproximadamente $500 \mathrm{ml} /$ minutos com o sistema em funcionamento normal. No fim dos testes, as configurações que demonstraram melhor disposição foram 
consideradas satisfatórias também nos quesitos de usabilidade e funcionabilidade dos componentes, e os materiais aplicados na estrutura do sistema forneceram resistência adequada para a finalidade proposta (Figura 10).

Figura 10 - Teste de funcionamento completo do sistema
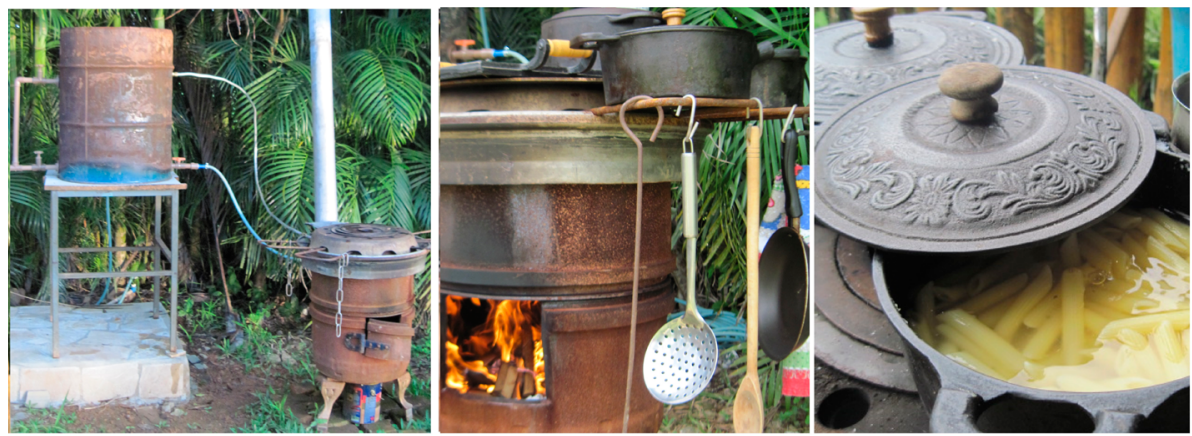

Fonte: arquivo pessoal

Após os diferentes testes, adequação dos componentes e finalização das atividades de validação, foram elaborados relatórios concernentes à construção do protótipo, medições, informações complementares e resultados.

\section{ANÁLISE ERGONÔMICA}

Na pesquisa, algumas etapas relacionadas à ergonomia foram aplicadas no sistema de cocção, como a apreciação e a diagnose ergonômica, mapeadas durante o uso no intuito de detectar as tarefas humanas relacionadas com o manuseio do sistema e os possíveis pontos de interação com os usuários.

As atenções foram direcionadas para a diagnose ergonômica, empregando-se uma análise macroergonômica e/ou a análise do Sistema Homem-Tarefa-Máquina (SHTM) (MORAES, 2009). 
Para a análise postural foram utilizadas as referências da ABNT NBR 9.050-acessibilidade a espaços, edificações, mobiliários e equipamentos urbanos. Como base de referência para a determinação dos valores utilizou-se, além do software Antroprojeto, as medidas antropométricas, levando em consideração o percentil 95\% para os homens com altura de 183,5 cm, o percentil $5 \%$ com $160 \mathrm{~cm}$ e o percentil 50\% com $171 \mathrm{~cm}$, segundo Couto (1995).

De acordo com o desenvolvedor do Antroprojeto, esse software permite ao usuário determinar, a partir do conhecimento da estatura de um indivíduo, suas demais dimensões corporais. Duas condições posturais são consideradas: indivíduo 'em pé' e 'sentado'. As estimativas dimensionais são baseadas nos trabalhos de Contini e Drillis (1966).

Tratando-se especificamente do uso de sistemas de cocção, foram consideradas as características relacionadas ao uso de mobiliário e suas delimitações de espaço. De acordo com os testes ergonômicos, a estrutura do sistema apresentou dimensões satisfatórias no que diz respeito às posturas e possibilidades de uso dos elementos.

\section{CONSIDERAÇÕES FINAIS}

A pesquisa de Mestrado Profissional em Design intitulada 'Desenvolvimento de produtos a partir do reúso de materiais metálicos descartados' investigou e identificou materiais passíveis de reúso que resultaram no desenvolvimento de um protótipo de um sistema de cocção, calefação e aquecimento de água, a partir da reutilização de materiais metálicos descartados, conforme Figura 11 abaixo. 
Figura 11 - Montagem final do conjunto

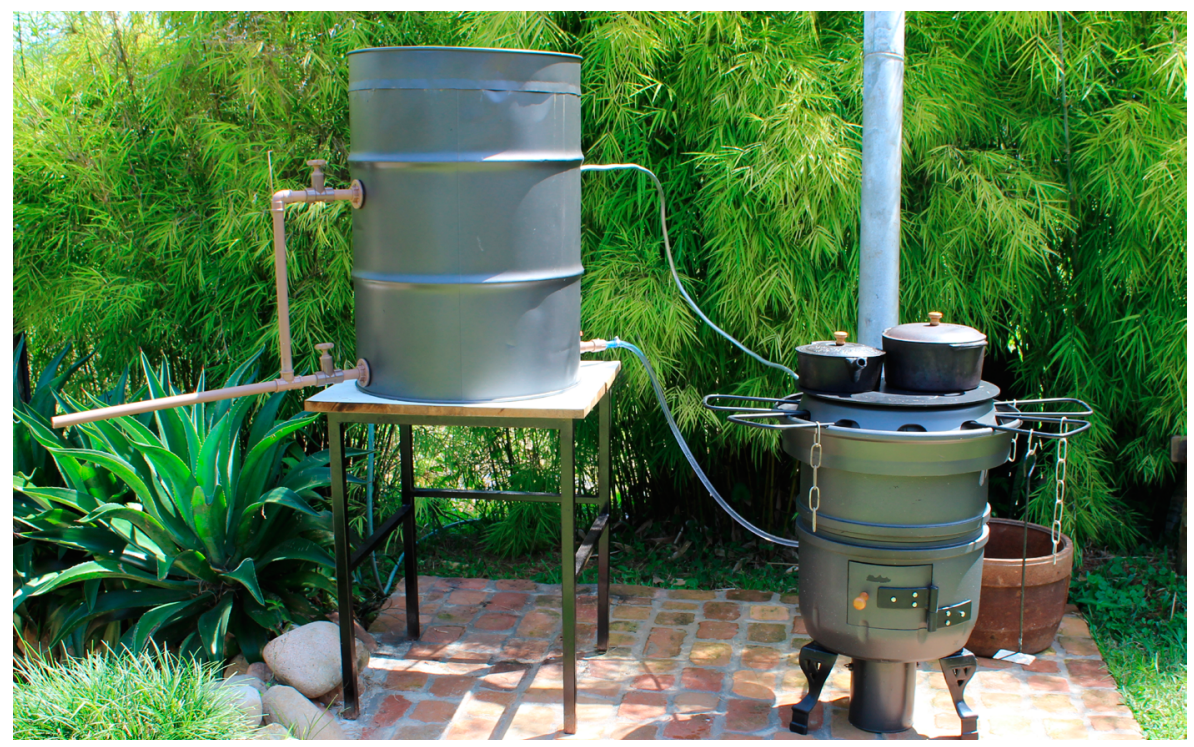

Fonte: arquivo pessoal

Os resultados desta pesquisa estão disponibilizados por meio de publicações em forma de memorial descritivo na internet (http://meureuso.blogspot.com.br/), visando o compartilhamento e aprimoramento acerca do reúso dos materiais. O projeto apresentou um conjunto de considerações que possibilitou o desenvolvimento de um produto que atendesse a necessidades específicas dos usuários.

A criação de novos artefatos a partir do reúso de materiais descartados apresenta uma possibilidade clara de abordar diferentes olhares no campo do design ao reaproveitamento dos resíduos, motivando novas pesquisas e aprofundamento na área como forma provocativa ao desenvolvimento de alternativas sustentáveis, considerando o ciclo de vida dos produtos e sobretudo promovendo uma reflexão sobre o excesso de descarte na sociedade, um sério problema que necessita de soluções inovadoras. 


\section{REFERÊNCIAS}

AMARAL, D. C. Gestão de Desenvolvimento de Produtos. São Paulo. Saraiva, 2006.

ANTROPROJETO. Software para estimativas antropométricas. Minas Gerais: Universidade Federal de Juiz de Fora, 2003.

ASSOCIAÇÃO BRASILEIRA DO DESENVOLVIMENTO INDUSTRIAL (ABDI). Disponível em: <http://www.abdi.com.br/abdi/publicacao/ engin>. Acesso em: 17 out. 2006.

BAXTER, M. Projeto de produto: guia prático para o design de novos produtos. São Paulo: Blucher, 2000.

COMPANHIA DE ELETRICIDADE DE SANTA CATARINA. Disponível em: $<$ http://novoportal.celesc.com.br/portal/index.php/noticias/1137banho-de-energia-no-globo-rural>. Acesso em: 16 nov. 2014.

GRANDJEAN, E. Manual de Ergonomia: adaptando o trabalho ao homem. 4. ed. Porto Alegre: Bookman, 1998.

INSTITUTO BRASILEIRO DE GEOGRAFIA E ESTATÍSTICA. Frota do Brasil. Disponível em: <http://cidades.ibge.gov.br/painel/frota.php>. Acesso em: 31 jul. 2014.

KASPER, C. P. Além da função, o uso. Revista Arcos Design, Rio de Janeiro, n. 5, dez. 2009.

MANZINI, E.; VEZZOLI, C. O desenvolvimento de produtos sustentáveis. São Paulo: EDUSP, 2010.

MINISTÉRIO DO MEIO AMBIENTE. Plano Nacional de Resíduos Sólidos. Versão preliminar para consulta pública. Disponível em: <http://www.mma.gov.br/estruturas/253/_publicacao/253_ 
publicacao02022012041757.pdf>. Acesso em: set. 2011.

MORAES, Anamaria de; MONT'ALVÃO, Cláudia. Ergonomia: conceitos e aplicações. Rio de Janeiro: [editora], 2009.

PORTAL BRASIL. Disponível em: <http://www.brasil.gov.br/meioambiente/2013/08/politica-nacional-de-residuos-solidos-completa3-anos>. Acesso em: 7 jun. 2014.

PREECE, J.; ROGERS, Y.; SHARP, H. Design de interação: além da interação homem-computador. Porto Alegre, RS: Bookman, 2005.

VIEIRA, L. O insustentável desenvolvimento. Revista ECO21, n. 209. Disponível em: <http://www.eco21.com.br/textos/textos. asp?ID=3250>. Acesso em: 20 set. 2014. 



\section{Resíduos da construção civil em pequenas obras: uma análise sob a ótica do design}

Mateus Szomorovszky (Currículo Lattes) Anna Luiza Moraes de Sá Cavalcanti (Currículo Lattes) Marli Teresinha Everling (Currículo Lattes)

\section{INTRODUÇÃO}

O homem, com suas atividades, vem alterando cenários naturais, degradando o meio ambiente e gerando uma quantidade exagerada de resíduos na busca por matéria-prima para o seu sustento físico, psíquico e econômico.

A Associação Brasileira de Limpeza Pública e Resíduos Especiais (ABRELPE, 2010) estima no Brasil um montante de aproximadamente cem mil toneladas de resíduos de construção civil produzidos em apenas um dia. Essas perdas de materiais de construção nas obras resultam do desperdício durante o seu processo de execução e dos restos de materiais que são perdidos por danos no recebimento, 
transporte e armazenamento. Desse valor, cerca de $90 \%$ dos resíduos gerados, que são suscetíveis de reaproveitamento e reciclagem, são desperdiçados pelas obras (AGOPYAN; JOHN, 2012). Considerando a contínua geração dos RESÍDUOS DA CONSTRUÇÃO CIVIL (RCC), pensar um novo processo de reaproveitamento torna-se de suma importância ambiental, social e financeira, no sentido de que estes retornem para a obra em substituição a novas matérias-primas que seriam extraídas do meio ambiente. Trata-se de uma atividade que deve ser prioritariamente realizada no próprio canteiro, mas que deve também ser executada fora dele, antes da obra, na otimização dos projetos, e após a obra, por meio do correto descarte.

Este artigo foi realizado a partir da pesquisa para o projeto de conclusão do Mestrado Profissional em Design na Univille. Com base na experiência dos autores no campo da arquitetura, frequentemente nos canteiros das obras que projeta, além de conversas casuais com construtores e empreiteiras, e de observações in loco para a elaboração deste trabalho, foi percebido que o acondicionamento dos resíduos nas pequenas construções e reformas ainda é feito de forma precária, desde a entrada dos insumos, sem o cuidado com o local de armazenagem, até posteriormente com a saída do resíduo; este é retirado por meio de sacos de lixo ou transportado diretamente pelo carrinho de mão até a caçamba coletora. Não há uma preocupação com a separação e limpeza dos ambientes, tampouco com as leis vigentes, como a Resolução no. 307 (de 5 de julho de 2002) do Conselho Nacional do Meio Ambiente (CONAMA), que estabelece diretrizes, critérios e procedimentos para a gestão dos resíduos da construção civil, cujos geradores são responsáveis pela caracterização dos resíduos, triagem, acondicionamento, transporte e destinação. 
Com base no exposto, o artigo apresenta conceitos inerentes ao Design de Serviços e à sustentabilidade, que podem contribuir para solucionar o problema de separação, acondicionamento e o transporte interno de resíduos da construção civil (RCC) de pequeno porte.

\section{SUSTENTABILIDADE E DESIGN}

Segundo o site do Ministério do Meio Ambiente, a Agenda 21 protocolada na Conferência Rio-92, pode ser definida como um instrumento de planejamento para a construção de sociedades sustentáveis, em diferentes bases geográficas, que concilia métodos de proteção ambiental, justiça social e eficiência econômica, ou seja, construir sem afetar o meio ambiente.

Autores como Pinto (2005), Roaf (2006) e Rogers (2013) defendem no design e na arquitetura um ciclo de vida sustentável para minimizar os impactos decorrentes de suas ações, com a configuração de um circuito fechado, com todos os subprodutos sendo reutilizados.

Associando o conceito do ciclo de vida sustentável à área da construção civil, o resultado seria a redução do descarte de materiais e dos impactos ambientais, a diminuição de custos da cadeia de produção, baixa barreira legal e a demanda crescente por uso do reciclado', conforme Figura 1.

1 Disponível em: <http://www.recinertambientale.com.br/>. Acesso em: 24 mar. 2015. 
Figura 1 - Fluxograma do ciclo ideal da construção civil

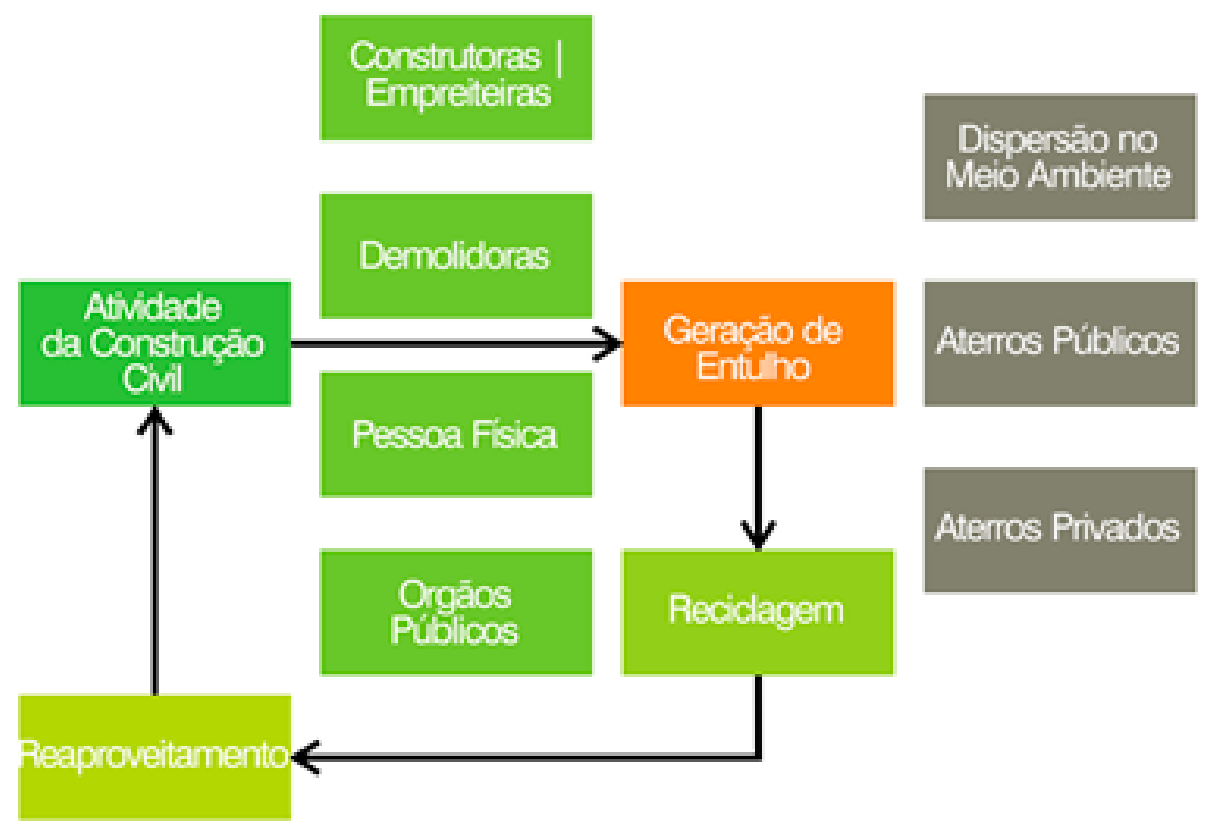

Fonte: adaptado de Recinert Ambientale (2015)

Apesar desse entendimento, Pinto (2005) aponta que as indústrias modernas ainda operam segundo paradigmas que foram desenvolvidos sem uma percepção mais abrangente da natureza, sem levar em conta a saúde, a complexidade e a interconectividade dos sistemas naturais na agenda do design industrial. Ademais, segundo Walker (2005 apud SOUZA, 2007, p. 31):

Apesar da disponibilidade de tecnologias sofisticadas, a abordagem atual do design, produção e distribuição dos produtos continua sendo a mesma, onde (sic) os recursos são extraídos da natureza processados, transformados em partes, montados como produtos, distribuídos em larga escala, usados, descartados e, por fim, substituídos. 
Um ciclo de vida não sustentável apresenta-se como modelo linear, tendo como resultante o desperdício. Para eliminar o conceito de desperdício, torna-se necessário projetar coisas-produtos, embalagens e sistemas-dentro do entendimento inicial de que o desperdício não existe.

O termo Design para a sustentabilidade pode ser definido, no sentido mais amplo, como uma prática de design, educação e pesquisa, que pode contribuir para o desenvolvimento sustentável. Portanto, com base nessa definição, faz-se necessário buscar uma solução para o acondicionamento dos RCC, desde a sua origem, no canteiro de obras, de maneira com que o novo serviço seja benéfico para toda a cadeia (VEZZOLI, 2010).

Nas últimas décadas verifica-se que a história da cultura e da prática do design passou por diversas mudanças, sobretudo no que se refere à sustentabilidade, passando do desenvolvimento "de produtos isolados para sistemas de produção de consumo, e de problemas estritamente ambientais para a mistura complexa de questões sociais e ambientais" (MANZINI apud VEZZOLI, 2010, p. 11). Em meados dos anos 90, o foco do design estava no nível do produto, no baixo impacto ambiental, conhecido como Product Life Cycle Design ou Ecodesign. Na virada do século foi definido como Design para Inovação de Sistemas Ecoeficientes. Recentemente, a pesquisa em design levou a discussão sobre o possível papel do design para equidade e coesão social (VEZZOLI, 2010).

Para as empresas, a mudança afeta a cultura corporativa, que passa a exigir um novo modelo de negócios, e, para os governos, a necessidade de definição e implementação de políticas que facilitem o andamento dos negócios das empresas. Em relação às cidades que já estão engajadas em um movimento de sustentabilidade, Rogers (2013) destaca: 
[...] as sociedades urbanas estão desenvolvendo estratégicas adequadas à sua cultura e necessidades específicas. Em cada uma delas, há um pressuposto fundamental: os cidadãos querem interferir na conformação das suas cidades. De forma enfática, elas provam que a participação popular aliada a um efetivo compromisso do poder público podem transformar a estrutura social e física de nossas cidades (ROGERS, 2013, p. 20).

Essas mudanças sociais já acontecem, e isso se reflete em como o design vê o mercado e como se pode intervir com mais eficiência na busca de um design voltado à sustentabilidade. Essa mudança transforma as metodologias utilizadas e norteia uma evolução de um simples pensar ecológico a um sistema inteiro para sustentabilidade. Em todo o processo é preciso pensar como avaliar o impacto ambiental, como reduzir o uso de recursos, como aperfeiçoar a vida do produto e estender a vida dos materiais, facilitar a desmontagem e a diminuição da geração de resíduos.

As preocupações de Vezzoli (2010) vêm ao encontro do que Pinto (2005) e Lima e Lima (2009) comentam em seus manuais de boas práticas para a construção civil, sobre a redução do impacto ambiental e da importância da análise do ciclo de vida dos materiais, nesse caso, a redução do resíduo e seu correto descarte.

Com isso, é possível associar esses conceitos com o design de Produto/Serviços, baseados em Zeithalm (2014) e Souza (2008). Anteriormente, a gestão de serviços era mais incidente nos setores bancários, de saúde e de hospitalidade, hoje se expandiu para setores de tecnologia, varejistas, bens de consumo e setor produtivo.

No caso dos RCC, faz-se necessário buscar novas ferramentas que aperfeiçoem o gerenciamento do resíduo, principalmente nas pequenas obras. As pessoas, cada vez mais, procuram serviços que solucionem seus problemas de uma maneira mais amigável, otimizada, transparente e sustentável. 
É um exemplo do que acontece atualmente com aplicativos de smartphones que estão quebrando paradigmas e monopólios até então intocados, como as empresas Airbnb², Uber ${ }^{3}$ e Alibaba ${ }^{4}$, líderes nos seus respectivos mercados, as quais não possuem sequer uma unidade do que vendem (quartos de hotel, táxis e estoque, respectivamente). A dificuldade na oferta de serviços com valores agregados colocam as empresas diante de desafios, como adequações socioculturais, inovações tecnológicas, entre outros fatores que 'modificam' a lógica do serviço antes prestado (SOUZA, 2008).

Quando adequamos esse pensamento aos serviços hoje prestados na construção civil, observa-se no canteiro que o cliente quer sua obra finalizada, limpa e entregue no prazo, independentemente do impacto ambiental e social causado, apesar de buscar elementos ecológicos na elaboração de projeto (aquecimento solar, reaproveitamento de água da chuva etc.) que justifiquem um pensamento sustentável. Tanto as empresas quanto os clientes devem adaptar-se às novas demandas sociais e ambientais e fazer com que todos os agentes participem do processo ativamente, sabendo como será a obra, quais os reais custos e o que será feito com o resíduo descartado.

Para o entendimento do design de serviços associado ao tema do presente trabalho, foi elaborado um fluxograma (Figura

\footnotetext{
2 Airbnb é um mercado comunitário confiável para pessoas anunciarem, descobrirem e reservarem acomodações ao redor do mundo, seja por computador, seja por tablet ou celular. Disponível em: <www.airbnb.com.br/about/about-us $>$.

3 Uber: conecta diretamente passageiro e motorista por meio de um aplicativo, gerando demanda por serviços compartilhados e novas possibilidades para a mobilidade urbana. Disponível em: <http://www.uber.com/pt/about>.

${ }^{4}$ Fornece tecnologia e serviços que permitem que os consumidores e comerciantes possam conduzir, por meio de um servidor único, compra e venda de produtos. Disponível em: $<$ http://alibabagroup.com/en/about/overview>.
} 
2) abrangendo o recorte de estudo, desde o descarregamento do insumo na parte externa do edifício, passando pela entrega (no interior do edifício), chegando à acomodação do insumo no local da obra, o manuseio dos artefatos, a geração dos resíduos e o acondicionamento, até a saída do resíduo para a coleta.

Figura 2 - Infográfico do ciclo de entrada e saída de insumo

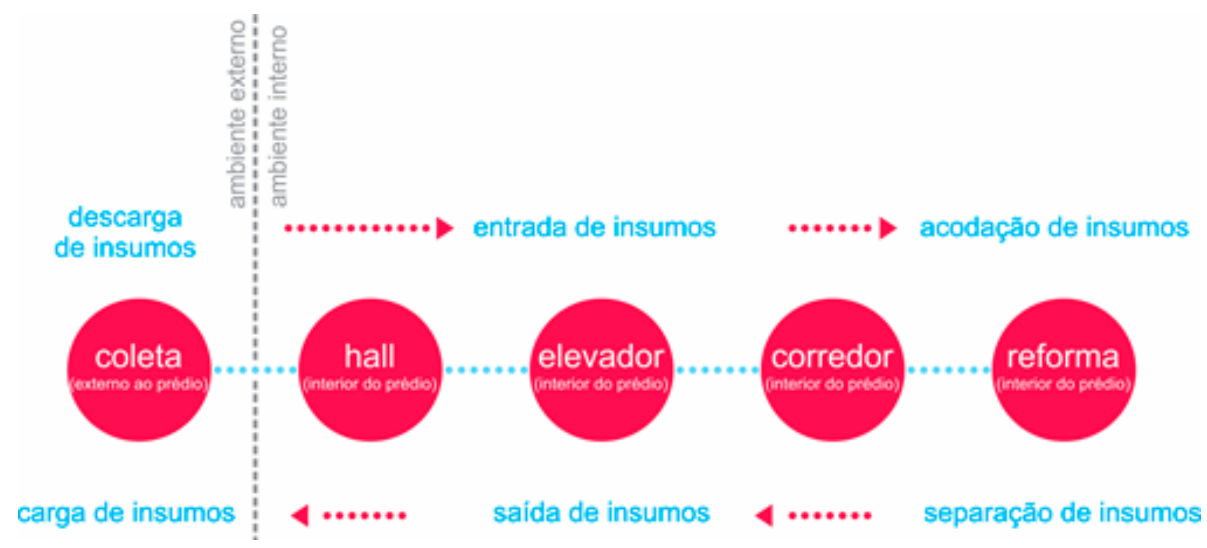

Fonte: elaborada pelos autores (2015)

O serviço de coleta, separação e o transporte interno dos resíduos da construção civil de pequeno porte, objeto de estudo desta investigação, se enquadram nas características do Design de sistemas para ecoeficiência, proposto na metodologia de Vezzoli (2010), que atende a uma demanda particular promovendo uma inovação específica, menos radical e com menos inovação tecnológica, mas focada na criação de novas interações e parcerias, objetivando a sustentabilidade, visto que:

[...] o design pode se tornar um efetivo agente promotor da sustentabilidade, pois o designer é o ator social que, pela natureza da sua profissão, é mediador privilegiado, entre artefatos e pessoas, na relações cotidianas e expectativas de bem-estar a elas atreladas (MANZINI apud VEZZOLI, 2010, p. 11). 
Assim, o papel do designer é articular todas as etapas de desenvolvimento de projeto, evidenciando a ecoeficiência nas etapas desse processo, desenvolvendo sistemas capazes de atender a seus clientes, engajando-os em interações inovadoras na busca da ecoeficiência (VEZZOLI, 2010).

\section{PROPOSTA DE SERVIÇO PARA A COLETA E ACONDICIONAMENTO DE RESÍDUOS DA CONSTRUÇÃO CIVIL EM PEQUENAS OBRAS}

Após analisar a jornada do resíduo, foram utilizadas ferramentas do design thinking no desenvolvimento da proposta de um sistema orientado para a sustentabilidade e a avaliação ambiental, socioética e econômica dos RCC.

Para a análise do sistema, foi utilizada uma planta de uma edificação hipotética de um edifício de apartamentos, pois esse tipo de edificação seria o mais complexo para otimização do serviço, visto que em shopping centers, salas comerciais e residências unifamiliares já existem espaços internos, mesmo que improvisados, para o acondicionamento dos RCC.

A proposta de serviço foi pensada em três etapas: a primeira, utilização de um espaço no corredor de cada andar para um pequeno depósito, a fim de acondicionar os dispositivos para os RCC, além de prateleiras de uso comum, onde haveria ferramentas manuais e elétricas para uso comum (Figura 3). 
Figura 3 - Planta baixa| depósito de utilidades

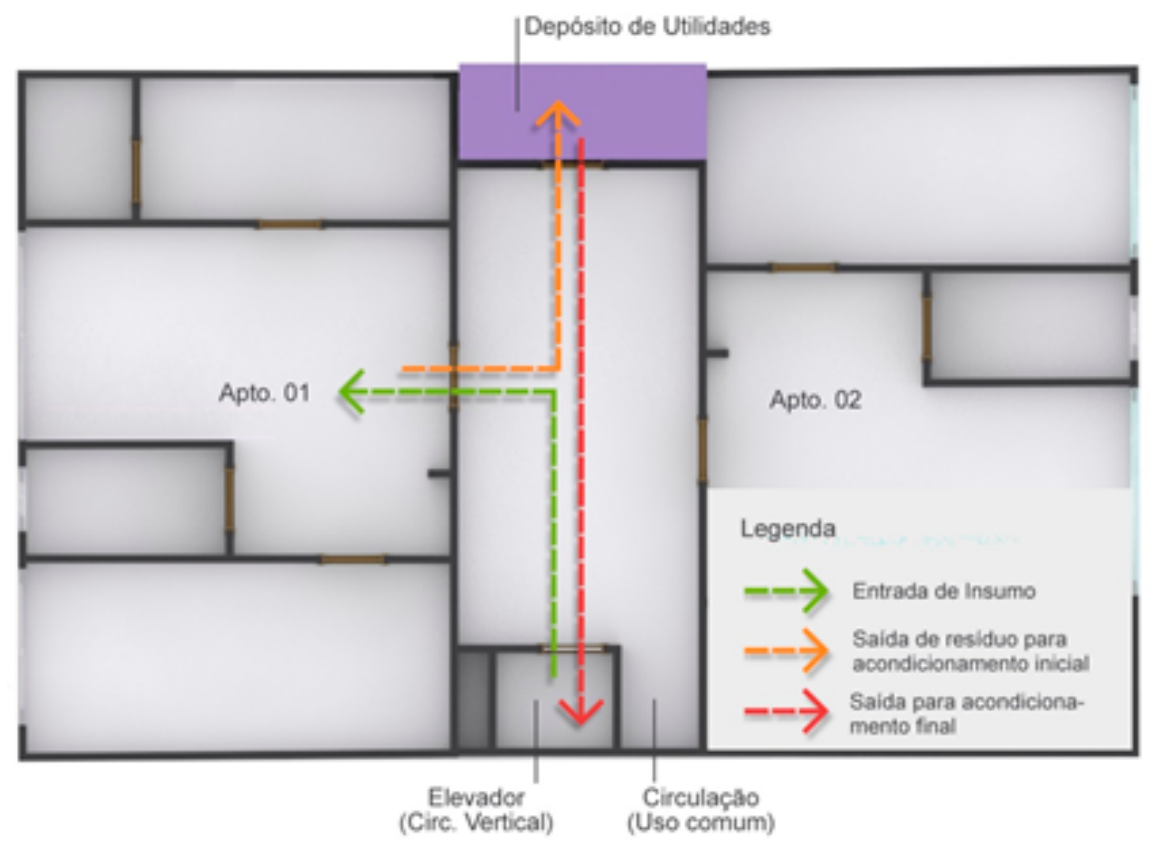

Fonte: elaborada pelos autores (2015)

Nesse espaço também estaria a área técnica de cada andar, com as caixas de distribuição de gás, iluminação, hidráulica e lógica, otimizando o espaço de uso comum, bem como o uso interno de cada apartamento/escritório.

A segunda etapa do processo de serviço para essa edificação estaria na acomodação dos dispositivos na área de garagem ou na área próxima ao lixo convencional. Importante que seja na área privativa do condomínio, para que os usuários sintam-se ainda 'proprietários' dos RCC gerados.

Com relação ao dispositivo de transporte dos RCC, foram considerados os seguintes requisitos: (1) passar em todas as portas; (2) reduzir a fadiga muscular do funcionário; (3) priorizar o acondicionamento, triagem e transportes internos em um único contenedor, diminuindo custos, tempo nos traslados de material; 
(4) ocupar o menor espaço possível na área prevista para o descarte final ( $240 \times 500 \mathrm{~cm}=$ equivalente a uma vaga de garagem). Depois dos estudos realizados, foi idealizada uma proposta de serviço, como uma alternativa à caçamba estacionária, com os parâmetros para desenvolvimento, como demonstra a Figura 4.

Figura 4 - Parâmetros de desenvolvimento da proposta de serviço Tornar o serviço atraente ao gerador

Como fazer com que o cliente opte pelo novo serviço, se hoje a caçamba estacionária cumpre a funçâo, que è 'eliminar' o residuo? Foi consenso nas discussōes do grupo que a consciência ambiental seria o primeiro passo para uma nova postura;
Fazer parcerias com condominios e sindicos. ancorados na NBR 16.280 , que dispōe sobre as diretrizes de um 'plano de reforma' que se torna obrigatório e em especial, da responsabilidade das incorporadoras e construtoras, projetistas e sindicos em relaçăo às reformas realizadas nas áreas comuns e privativas do edificio (ABNT, 2014).

\section{Transparência}

O cliente devera saber qual o destino do seu RCC, pois ele está pagando por isso.
Ele deverá perceber que o residuo recolhido por esse novo serviço terá um destino mais nobre que o serviço convencional.

Leis, impostos e incentivos fiscais e financeiros

- Viabilizar novas leis e um aumento de impostos sobre o descarte do RCC, proporcionando uma penalizaçăo financeira ao gerador, que irá ter consciência que irá gastar da próxima vez que eliminar o residuo;
- Remunerar o gerador sobre o residuo coletado em bom estado, de forma a incentivar a correta separaçăo e bom estado dos materiais.

\section{Treinamento}

O gerador nåo tem o sentimento de responsabilidade sobre o RCC após a sua ida para a caçamba estacionária, jả no ambiente público. A capacitação por meio de cartilhas, palestras, cursos, aplicativos on-line ou envolvimento dos agentes da cadeia produtiva da construção civil, para informar sobre esse novo serviço.
A conscientizaçăo sobre as vantagens desse novo serviço deve acontecer desde a etapa de projeto até o descarte no aterro sanitário.

Fonte: primária (2015) 
A partir dos parâmetros, foi criado um infográfico (Figura 5), que mostra a idealização do sistema/serviço considerando uma reforma em um edifício de apartamentos (as etapas estão descritas logo após a figura).

Figura 5 - Infográfico da proposta do sistema/serviço

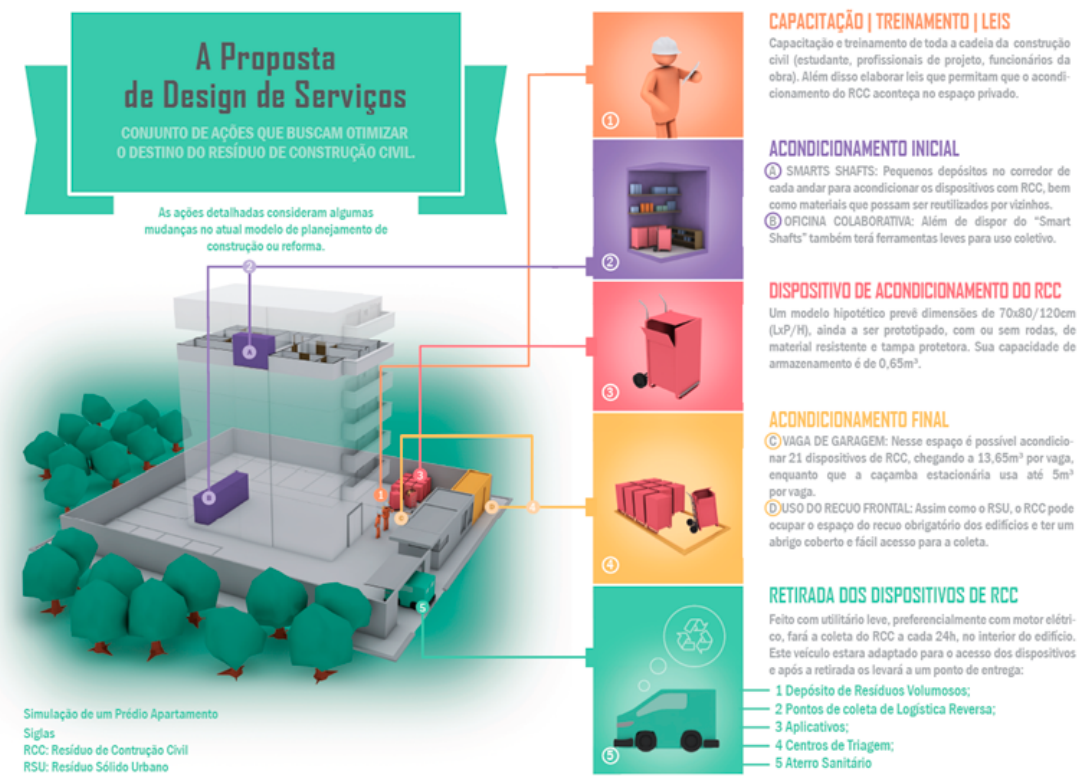

Fonte: primária (2015)

1. O serviço prevê a capacitação e treinamento de toda a cadeia da construção civil, desde o estudante, passando pelos profissionais de projeto, até os funcionários da obra, por meio de cursos, ensino a distância (EAD), palestras e manuais de boas práticas. Praticar as leis existentes e instigar novas, que permitam que o correto acondicionamento dos RCC aconteça no espaço privado, ancorado em normas como a NBR 16.280 e que tenham cunho informativo e propositivo. 
2. Prever locais internos no edifício, seja em novos projetos, seja nos já construídos, que promovam uma 'corrente colaborativa', como:

- Depósito de utilidades: nas novas obras de prédios, prever pequenos depósitos no corredor de cada andar (prédios novos) para acondicionar os dispositivos móveis com RCC, bem como materiais que possam ser reutilizados por vizinhos, como restos de tinta, metais sanitários, spots de iluminação, entre outros produtos. A proposta também prevê dispor de pequenos objetos de uso esporádico, mas que ocupam espaço nas áreas privativas dos apartamentos, como caixa de ferramentas leves para uso coletivo, furadeira, escadas de pequeno e médio porte. Também estariam alocados nesse espaço a área de manutenção de rede elétrica, lógica, hidráulica e gás, chamados shafts.

- Oficina colaborativa: local previsto no andar térreo, um pouco maior que os depósitos de utilidades, que além de dispor dos utensílios citados no item 2.1 também teria bancadas para trabalho.

3. Dispositivo para acondicionar o RCC com dimensões de $70 \mathrm{x}$ $80 / 120$, com ou sem rodas, de material resistente e tampa protetora com capacidade de armazenamento de 0,65 $\mathrm{m}^{3}$.

4. Baseado em leis correlatas, os RCC teriam dois possíveis locais para acondicionamento final, dependendo das condições de espaço no edifício:

- Vaga de garagem: o código de posturas do município prevêvaga com dimensões de 2,40 × 5,00 m para automóveis, totalizando uma área de $12 \mathrm{~m}^{2}$. Nesse espaço seria possível acondicionar 21 dispositivos de RCC, chegando a 13,65 $\mathrm{m}^{3}$ por vaga, enquanto que a caçamba estacionária usaria a mesma vaga e forneceria entre 3 e $5 \mathrm{~m}^{3}$ por vaga.

- Uso do recuo frontal: os RCC poderiam ocupar o espaço do 
recuo obrigatório dos edifícios e ter um abrigo coberto e fácil acesso para a coleta, sendo disponibilizado pelo condomínio, assim como já acontece com o RESÍDUO SÓLIDO URBANO (RSU).

5. Coleta dos dispositivos de RCC: seria realizada por meio de um utilitário leve, preferencialmente com motor elétrico a cada 24h. Esse veículo estaria adaptado para o acesso e acomodação dos dispositivos.

5a. Aplicativos: O serviço pode ser disponibilizado por um aplicativo para smartphones e tablets, com o intuito de torná-lo ágil, prático, atraente e amigável ao gerador de resíduos e população em geral, facilitando o acesso às informações, horários de coleta, orientação sobre separação e acondicionamento, identificação e denúncia de descarte em áreas proibidas, consultoria de projetos, entre outros assuntos que podem ser discutidos em estudos futuros. É importante fazer com que a população e o gerador de RCC sintamse parte do processo e exerça seu papel como cidadão.

5b. Destino do resíduo: Após a coleta dos dispositivos de RCC, o utilitário levará até um ponto de entrega que, dependendo do tipo de resíduo, poderá ser:

- Depósito de resíduos volumosos: abrigaria os materiais passíveis de reúso como: esquadrias, louças, metais, pisos, isolamentos e móveis, assim como sobras de tintas. O serviço se estenderia a consultorias de projeto arquitetônico, em que seriam adaptados os materiais às necessidades dos clientes, gerando mais uma experiência positiva no processo;

- Pontos de coleta para logística reversa: atualmente, o Programa Nacional de Resíduos Sólidos (PNRS) prevê o retorno de apenas seis produtos para as empresas responsáveis. Na condição ideal, o maior número possível de RCC deveria retornar para 
a empresa de origem, principalmente os de Classe $C$ (não recicláveis) e $D$ (perigosos), pois as empresas fabricantes devem ter responsabilidade sobre eles. De acordo com o PNRS (2010), é importante no planejamento estratégico das organizações adequá-las à legislação do meio ambiente atual, para o correto destino dos RCC. Os depósitos de resíduos volumosos poderiam funcionar como centros de coleta e triagem para as empresas.

- Centros de triagem: os resíduos de Classe A e B, como derivados do concreto e madeira, não reaproveitados para o depósito de resíduos volumosos, seriam levados aos centros de triagem, para a fabricação de agregados (areia reciclada, pedrisco reciclado, rachão) e recolocados no mercado como agregados reciclados.

- Aterro sanitário: resíduos sem potencial de aproveitamento ou reciclagem no próprio canteiro de obras seriam destinados adequadamente aos aterros sanitários, onde encerra o ciclo de vida do produto.

\section{CONSIDERAÇÕES FINAIS}

Por meio das pesquisas bibliográficas, constatou-se que leis e normas técnicas existem e são bem elaboradas, porém pouco aplicadas. As cidades não estão totalmente preparadas para receber os RCC de forma correta, e embora a eliminação dos resíduos da construção civil seja a solução mais favorável para a minimização dos impactos ambientais, é necessário considerar que será fruto de um processo lento e gradativo, exigindo a cooperação de todos os agentes da cadeia produtiva.

As ferramentas do Design foram fundamentais para o entendimento do processo e a elaboração do sistema de 
acondicionamento e transporte, e os principais resultados que poderão surgir por meio do serviço proposto são: (1) benefícios ao meio ambiente e à qualidade de vida das cidades; (2) redução da utilização dos recursos naturais, que são finitos; (3) redução das áreas necessárias para aterros; (4) a produção de agregados com base no entulho, como blocos e base de pavimentação; (5) a melhoria da poluição visual e mobilidade, com menos caçambas estacionárias em vias públicas; (6) a limpeza da obra; (7) funcionários trabalhando de forma correta e ergonômica.

Portanto, o serviço proposto vai além do simples fato de acondicionar, separar e transportar de maneira correta os RCC. Visa implantar uma nova cultura sustentável na cadeia produtiva da construção civil. 


\section{REFERÊNCIAS}

ASSOCIAÇÃO BRASILEIRA DE EMPRESAS DE LIMPEZA PÚBLICA E RESÍDUOS ESPECIAIS (ABRELPE). Panorama dos Resíduos Sólidos no Brasil: manual de Boas Práticas. São Paulo, 2010.

. NBR 16.280: Reforma em edificações-Sistema de gestão de reformas-Requisitos. Rio de Janeiro, 2014.

AGOPYAN, V., JOHN, V. M. O desafio da sustentabilidade na construção civil. São Paulo: Blucher, 2012.

BRASIL. Ministério do Meio Ambiente. Guia para elaboração dos Planos de Gestão de Resíduos Sólidos. Brasília, 2011.

CONAMA. CONSELHO NACIONAL DO MEIO AMBIENTE. Resolução 307/2002. Destino de Resíduos da Construção e Demolição, 2002. Disponível em: <http://mma.gov.br/download/resolucao/federal/ conama2002.pdf >. Acesso em: 28 abr. 2013.

JOHN,V.M. Reciclagem deresíduos na construção civil: contribuição à metodologia de pesquisa e desenvolvimento. Tese (Livre Docência) - USP, São Paulo, 2000.

LIMA, R. S.; LIMA, R. R. R. Guia para elaboração de projeto de gerenciamento de resíduos da construção civil. Paraná: CREA-PR, 2009.

MANZINI, E.; VEZZOLI, C. O desenvolvimento de produtos sustentáveis: os requisitos ambientais dos produtos industriais. São Paulo: EDUSP, 2002.

PINTO, T. P. Gestão ambiental de resíduos da construção civil. São Paulo, 2005.

. Reciclagem/destinação de resíduos. Revista Téchne, São Paulo, n.162, p. 59, set. 2010. 
PINTO, T. P.; GONZÁLEZ, J. L. R. Manejo e Gestão de Resíduos da Construção Civil: como implantar um Sistema de Manejo e Gestão dos Resíduos da Construção Civil nos municípios. Brasília: Caixa Econômica Federal; Ministério das Cidades: Ministério do Meio Ambiente, 2005.

ROAF, S.; THOMAS, S. Ecohouse: a casa ambientalmente sustentável. São Paulo: Bookman, 2006.

ROGERS, R.; GUMUCHDJIAN, P. Cidades para um pequeno planeta. 1. ed., 6. impressão. Barcelona: Gustavo Gili, 2013.

SOUZA, P. F. A. Sustentabilidade e responsabilidade social no design do produto: rumo à definição de indicadores. 2007. 294 f. Tese (Doutorado) - Faculdade de Arquitetura e Urbanismo, Universidade de São Paulo, São Paulo, 2007.

SOUZA, M. Design de serviços: seu cliente vivenciando uma notável experiência de atendimento. São Paulo: Clube dos Autores, 2008.

VEZZOLI, C. Design de sistemas para sustentabilidade: teoria e ferramentas para o design sustentável de "sistemas de satisfação". Salvador: EDUFBA, 2010.

ZEITHAML, V. A.; BITNER, M. J.; GREMLER, D. D. Marketing de Serviços: a empresa com foco no cliente. Nova lorque: Bookman, 2014. 


\section{0 processo criativo, a arquitetura e o design na vivência da experiência Refúgio Criativo}

Miguel Canãs Martins (Currículo Lattes) Marli Teresinha Everling (Currículo Lattes)

\section{INTRODUÇÃO}

Ao longo da reflexão conduzida sob a forma de dissertação (realizada noâmbito doPrograma demestrado profissionalem Design/ PPGDesign da Univille) os processos criativos e o papel da imersão', a subjetividade do usuário e as interseções metodológicas entre as

\footnotetext{
1 Segundo Viana (2012), trata-se da etapa em que a equipe de projeto se aproxima com mais profundidade do contexto do problema, tanto do ponto de vista do cliente como do usuário final. Destaca-se que, embora Viana aborde a imersão ao discorrer sobre design thinking, nesta dissertação esta associação não é compulsória pela percepção, que boa parte das abordagens de Design, em maior ou menor escala, também fazem uso dessa etapa mesmo que utilizando outras nomenclaturas.
} 
áreas de Arquitetura e Design estiveram no centro do processo. A discussão teve como objeto a análise da prática profissional adotada pelo escritório de arquitetura Metroquadrado, do qual Miguel Cañas (autor da dissertação) é sócio. Por esse envolvimento, pela escolha de situar as equipes e as pessoas envolvidas no estudo no centro do processo e em respeito a coautoria dos participantes, o relato será realizado na primeira pessoa do plural.

O objetivo central da experiência foi discutir os processos criativos nas áreas de Design e Arquitetura e suas interseções, considerando aspectos de imersão e de experiência para projetos de arquitetura (especialmente o contexto da Metroquadrado). Para isso, caracterizamos o escritório; abordamos conceitos associados à criatividade e a experiência em um contexto de arquitetura-arte; identificamos possibilidades de aproximação entre Arquitetura e Design, abrangendo arquitetura no contexto de atuação da Metroquadrado; realizamos experiências e atividades imersivas no âmbito interno do escritório e no âmbito externo, exercitando a interdisciplinaridade; e, por fim, abordamos as repercussões da discussão teórica e das atividades prático-imersivas nos projetos desenvolvidos com clientes ao longo desta discussão e, na sexta etapa, discutimos possibilidades futuras.

Destacamos que neste relato pretendemos abordar sobretudo as experiências e atividades imersivas conduzidas sob a forma de workshop envolvendo arquitetos, designers e profissionais de outras áreas com o intuito de proporcionar o compartilhamento de experiências pessoais/profissionais e o desenvolvimento de um trabalho coletivo com foco na atividade de projetar. Essa escolha deriva do significado que a experiência teve para a trajetória da dissertação e do sentido que assumiu para os participantes. 


\section{CONTEXTUALIZANDO A EXPERIÊNCIA: O INÍCIO DE TUDO}

O percurso preliminar que conduziu ao Refúgio Criativo envolveu, em um primeiro momento, a caracterização do escritório Metroquadrado, considerando a localização e o histórico da empresa, seu posicionamento, sua atuação, áreas de interesse e relevância da discussão sobre identidade; em seguida, conduzimos um breve panorama sobre conceitos de criatividade e experiência no âmbito deste projeto, abordando, num primeiro momento, a importância desse tema no contexto da Metroquadrado.

Posteriormente, discutimos as ações de criatividade da Metroquadradoeos processoscriativosdaempresaàluzdaabordagem de autores como Watson (2013), Ostrower (2013), Naccache (2013), Medeiros (2004), Cross (2004) e Gomes (2001) e discorremos sobre a noção de experiência em uma abordagem que aproxima arquitetura e arte com base no pensamento de Dornburg (2002), Pallasma (2005) e Abellán (2014); esses autores discutem características mais dinâmicas, multifuncionais e mutantes para a arquitetura, visando proporcionar diferentes dimensões da experiência humana ao apontar um novo paradigma da área, que leva em conta os sentidos e o corpo. Também apresentamos conceitos e possibilidades de aproximação entre design e arquitetura; abordamos, principalmente com base em Edson Mahfuz (2003, 2013, 2014) e Ciro Pirondi (2014), os diversos componentes que caracterizam a arquitetura e que fazem essa disciplina transitar ao mesmo tempo por áreas como engenharia e arte, razão pela qual a história da humanidade teve tanta dificuldade em precisar seu significado. Apresentamos também algumas definições sobre processos metodológicos para projetos de Arquitetura, mais intensamente na visão de Biselli (2011), Segawa (2014), Kahn (1991) e Lemos (2003), acrescentando na sequência 
o processo de atuação da Metroquadrado, considerando equipe, processos e trabalho e detalhamento das etapas de projeto. Logo após, refletimos acerca de possíveis contribuições do Design em procedimentos de Arquitetura no processo de trabalho do escritório Metroquadrado, considerando as abordagens de Sanders (2005, 2008, 2010), Cross (2004), Maurício Viana et al. (2012) e Brown (2010). Procuramos refletir sobre como podemos projetar experiências e acessar emoções do usuário e abordamos a sua participação no processo, questionando como alcançar anseios subjetivos do cliente/ usuário; em seguida, abordamos afinidades entre arquitetura e design no contexto do escritório Metroquadrado. Na sequência, concluímos com a observação de interseções percebidas entre as duas áreas e o processo do escritório, novamente a partir de Tim Brown (2010), Maurício Viana et al. (2012) e Nigel Cross (2004).

Após esse percurso, planejamos, vivenciamos e discutimos as práticas imersivas para a exploração das afinidades entre Arquitetura e Design no contexto da Metroquadrado e para além dele. Esta abordagem abrange a preparação, condução e desdobramentos do Refúgio Criativo (workshop destinado à experimentação interdisciplinar dos processos associados, especialmente, à Arquitetura e Design) e dos três workshops internos conduzidos com a equipe da empresa. Destacamos que doravante o relato abordará com maior intensidade as atividades relacionadas ao Refúgio Criativo. 


\section{A PREPARAÇÃO DO REFÚGIO CRIATIVO}

Em virtude do interesse latente do escritório Metroquadrado na área do Design, há um movimento de aproximação com profissionais dessa área, sobretudo, com a equipe do escritório de design Firmorama (descrito em seu site como escritório de design e estúdio criativo); essa proximidade é o desdobramento do relacionamento interpessoal entre os sócios das duas empresas que se conheceram, passaram a trocar referências e a se reencontrar em atividades de interesse comum.

A intensificação do convívio entre as duas equipes originou um movimento apelidado de 'Metrorama' (junção de nomes Metroquadrado e Firmorama), que tem como ideia central intensificar a interdisciplinaridade das duas áreas na atuação das duas empresas. As afinidades e os diálogos constantes sobre os processos de trabalhos de cada empresa transformaram-se em indicações de trabalho de ambos os lados no intuito de apresentar aos clientes a oportunidade de se desenvolver um projeto mais abrangente ao oferecer arquitetura e design juntos.

A partir da percepção das coincidências na forma de pensar decidiram evidenciar com mais ênfase o suporte que uma área poderia dar à outra. No entanto, mais do que um trabalho complementar, o maior interesse estava em elaborar uma forma de trabalho diferente do que vinham fazendo. $O$ primeiro encontro que selou essas intenções foi realizado no dia 2 de outubro de 2014. A síntese redigida a partir desse encontro pode ser assim expressa: utilizar princípios de design de experiência para aliar arquitetura e identidade, posicionamento e criação no envolvimento do negócio dos clientes em etapas de descobertas anteriores ao briefing, construir o briefing com o cliente, ter liberdade experimental e atuar 
como curadores de informação. Estava claro que pretendíamos uma abordagem centrada em pessoas e seus anseios. Projetar para marcas fundamentou-se sobre o mesmo pressuposto: em se reconhecendo a essência da marca revela-se um propósito que a torna pessoal.

Ressaltamos que até esse momento o autor desta dissertação estava mais inclinado ao desenvolvimento de uma proposta metodológica sistematizada e mais orientada para sua própria atuação apesar de já haver um forte interesse pelas etapas iniciais de imersão/preparação para o projeto. A partir desse encontro o foco da dissertação deixou de ser pessoal e assumiu um caráter mais voltado para a atuação coletiva da equipe Metroquadrado e passou a contar com a sua participação por meio de workshops, reuniões e conversas informais. Esse encontro também foi decisivo para concepção e preparação do Refúgio Criativo.

Planejamos o Refúgio Criativo como um workshop orientado para atividade prático-criativa-imersiva, com o intuito de proporcionar dois momentos distintos (ambos interessados nos processos criativos de cada participante/empresa): o compartilhamento e depoimentos individuais e o desenvolvimento de um trabalho coletivo, sendo este projetar uma cabana. Pretendíamos com isso ampliar o campo de visão dos participantes de modo a favorecer o trabalho individual de cada um ao discutir procedimentos que fazem parte das práticas de trabalho dos profissionais envolvidos (contribuindo para a intersecção entre as áreas).

O workshop foi planejado para ocorrer em dois dias e foi agendado para os dias 29 e 30 de novembro de 2014, tendo a natureza e os espaços ao ar livre como cenário em uma chácara localizada em Blumenau/SC. A Metroquadrado e a Firmorama, representadas pelos sócios Miguel Cañas Martins e Jackson Peixer, formaram uma comissão organizadora responsável por desenhar e conduzir o 
workshop, sua estratégia, conteúdo, cronograma de atividades e identidade. Como mediadores, isso incluiu organizar e discutir cada momento, etapa ou ação realizada durante o fim de semana, bem como planejar o workshop na fase preliminar cuidando de cada detalhe; esse planejamento teve início em setembro de 2014.

A criação do roteiro do workshop também foi colaborativa. $O$ trabalho em conjunto utilizou de ferramentas online, permitindo que os líderes criassem e editassem documentos simultaneamente, colaborando em tempo real. Essas ferramentas facilitaram o desenvolvimento das fases do workshop, como descrever o roteiro, discutir a lista de materiais ou atribuir tarefas. Além disso, discussões sobre logística e necessidades, como uso de barracas, lanternas, repelentes, também foram abordadas.

No intuito de proporcionar uma imersão aprofundada e exercitar o foco dos participantes para que a experiência fosse a mais completa possível, discutimos bastante sobre a geração de conteúdo, de imagens e vídeos que o workshop geraria. Portanto, cada detalhe do processo deveria ser pensado não só por sua experiência de uso, mas como uma expressão estética.

Embora o roteiro tenha sido criado com recurso de planejamento e organização das ações e atividades conduzidas ao longo do workshop, foi considerado desde o início que não se tratava de uma experiência com procedimentos fechados. Era preciso que a equipe tivesse liberdade para adequar-se ao contexto de acordo com seus objetivos. Deveria haver espaço para o improviso. O tom da conversa deveria ser o mais informal, livre e espontâneo possível.

A fase de preparação para workshop também previu algumas tarefas para todos os participantes: (1) cada empresa deveria enviar sua marca e um release de apresentação; (2) cada pessoa enviaria duas imagens que fossem representativas para si (o objetivo disso 
era surpresa e seria apresentado no dia do workshop); (3) cada participante levaria um artefato que era importante para si ou que carregasse uma história interessante para ser compartilhada com o grupo todo; (4) cada um levaria o material que acredita que seja interessante compartilhar com todos, referências impressas, livros, anotações e tudo que puder servir de base para que construíssemos em conjunto as discussões.

Em termos mais subjetivos pretendíamos proporcionar espaços para o silêncio, a experimentação e a contemplação, no intuito de promover uma entrega total e em profundidade. Queríamos criar um espaço favorável para atividades prático-criativas e de autoconhecimento. Esses objetivos definiram o nome do workshop: Refúgio Criativo.

Em termos mais objetivos, o Refúgio Criativo foi planejado para ser uma pausa no espaço-tempo cotidiano e privilegiar o projeto coletivo (com a participação de designers e arquitetos). Pretendia proporcionar o exercício do olhar e o pensamento reflexivo, explorando o processo projetual de forma mais experimental, no intuito de potencializar a experiência das pessoas na paisagem, como um artefato-manifesto que transcendesse o conceito de espaço físico: de um lugar para estar a um momento para sentir.

Para orientar as atividades, uma série de temáticas pertinentes aos processos de trabalho de cada um foi considerada; incluímos no planejamento uma etapa para abordagem de: desempenhos profissionais, design autoral, trabalhos colaborativos, valores sociais, liberdade, tempo, foco, riscos, medos, inovação, tradicionalismo etc. Ou seja, reflexões sobre modelos alternativos, correlações e novas possibilidades de aprendizados por meio do depoimento dos outros.

O planejamento e a realização do refúgio envolveu cinco empresas de áreas distintas e complementares, localizadas na 
região norte do estado de Santa Catarina: a Vasselai, construtora de Blumenau; a Firmorama, estúdio de design gráfico e ilustração de Jaraguá do Sul; a Metroquadrado, escritório de arquitetura de Joinville; e o estúdio de fotografia e vídeo Entremonte, de Jaraguá do Sul. Além disso, um profissional externo, o terapeuta e designer Luis Fernando Leier, foi convidado a participar das atividades compilando as informações debatidas.

Apesar do compartilhamento de diversas informações entre todos os participantes do refúgio nas semanas que antecederam o workshop, muitos detalhes só foram compartilhados entre os organizadores. Isso incluía o próprio roteiro de atividades e experiências que seriam proporcionadas. Entre as surpresas estavam a escolha do cardápio de cada refeição que seria servida (café da manhã, almoço e janta), a seleção da trilha sonora que serviria de música ambiente durante as atividades e a entrega de um kit de desenho (Figura 1).

Figura 1 - Materiais de apoio desenvolvidos para o Refúgio Criativo
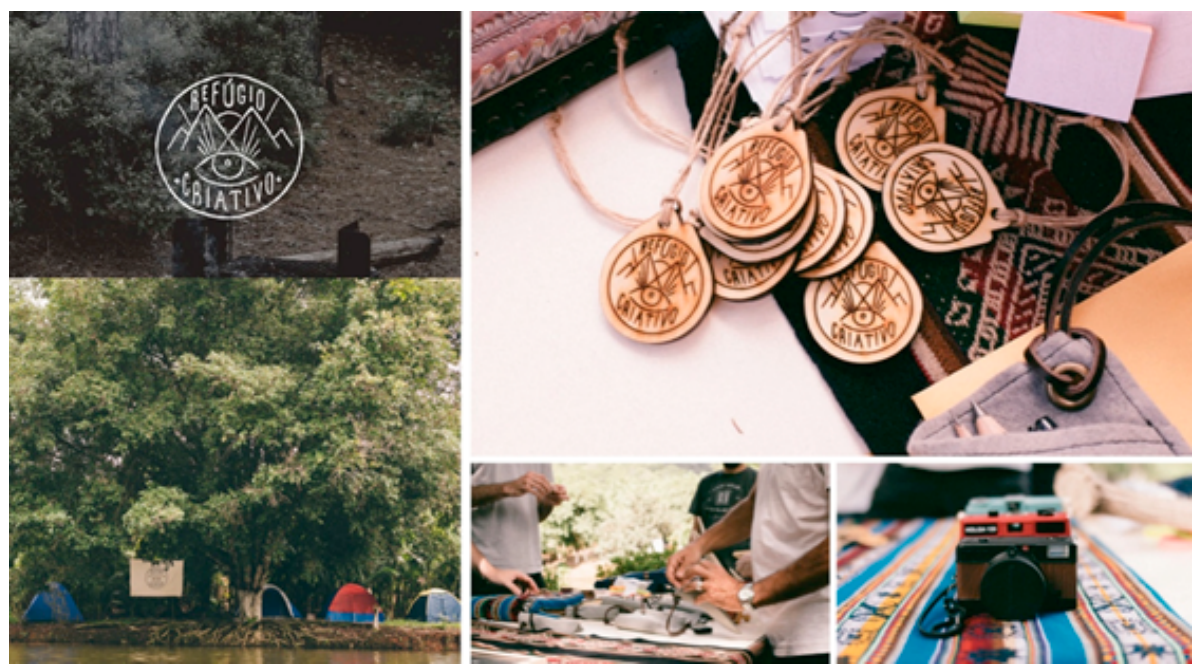

Fonte: Entremonte (Estúdio de fotografia e vídeo) 
O kit foi composto de um estojo de feltro e couro, desenhado especialmente para o refúgio, composto de canetas, lápis e borracha, bem como um caderno personalizado de desenho e anotações contendo o manifesto do Refúgio, o nome das empresas, as fotos que cada participante havia enviado anteriormente e a marca criada para o Refúgio Criativo, além de outras páginas impressas com elementos gráficos, fotos, textos e desenhos. Carimbos com a marca do Refúgio Criativo, adesivos e canecas de alumínio personalizadas também compunham os materiais entregues a cada participante. Por último, cada um recebeu um pequeno banco de madeira, executado especialmente para o refúgio, que serviu de apoio para as atividades realizadas em meio a natureza.

Por se tratar de uma experiência imersiva projetada para exercitar a atenção, o foco e o distanciamento das distrações e pensamentos do dia a dia, utilizamos essencialmente apenas meios analógicos de desenho e comunicação. Portanto, recomendamos que não fossem levados computadores, laptops e telefones celulares para o refúgio.

\section{Durante o primeiro dia...}

No primeiro dia o Refúgio Criativo teve seis momentos bem definidos, que foram: descompressão, autoconhecimento, lanche, temáticas/oficinas do futuro, alimentação \& depoimento, fogueira \& celebração.

A descompressão. O sábado pela manhã foi o período da chegada de todos. Foi um momento de informalidade, destinando a provocar um respiro e relaxamento, promovendo o distanciamento da rotina do dia anterior de cada participante. Foi o momento de observação, reconhecimento do terreno por meio de caminhadas, conversas informais entre os participantes, familiarização com as 
ferramentas de trabalho e tecnologias disponíveis e instalação do acampamento (Figura 2), entre outras atividades.

Figura 2 - localização do acampamento Refúgio Criativo

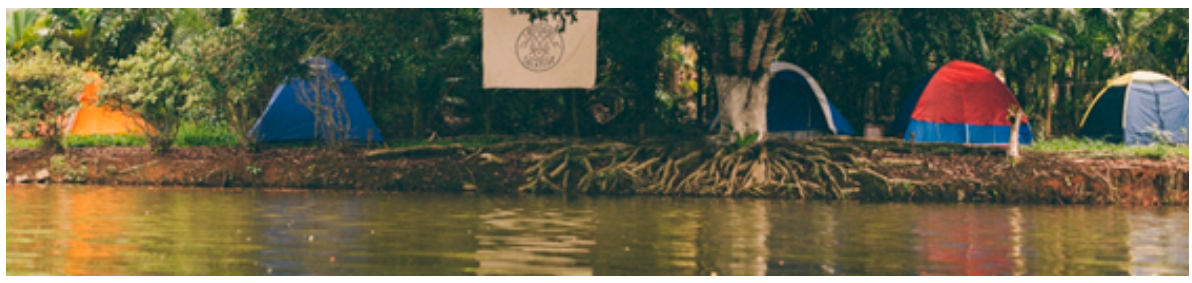

Fonte: Entremonte (estúdio de fotografia e vídeo)

Ao redor de uma mesa ao ar livre, organizamos todo material levado para o refúgio; montamos, de forma participativa, os kits surpresa para cada participante (Figura 3). Foi um momento que gerou, já desde o começo, uma atmosfera de cumplicidade e empatia.

Figura 3 - organização dos Kits de apoio

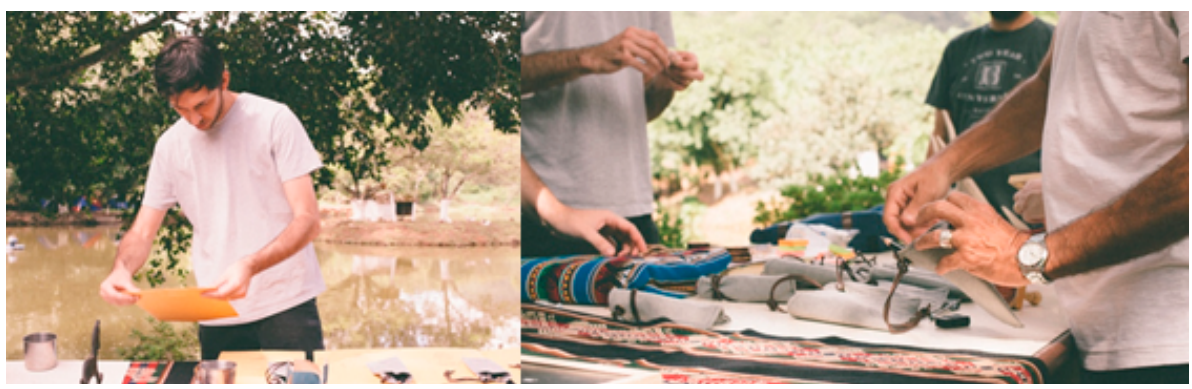

Fonte: Entremonte (estúdio de fotografia e vídeo)

O autoconhecimento. De posse dos kits personalizados, nos dirigimos a outra área do terreno. Trabalhar em lugares diferentes do terreno para cada atividade foi importante para dar contraste aos momentos, facilitado a identificação do começo e término de uma ação e a colaboração intensificando o envolvimento em cada experiência (essa atividade possibilitou reconhecer possibilidades do 
terreno). Sentados em círculo nos bancos de madeira no meio de um bambuzal, abrimos a experiência apresentando o projeto do Refúgio e seu propósito (Figura 4).

Figura 4 - atividade relacionada ao momento 2

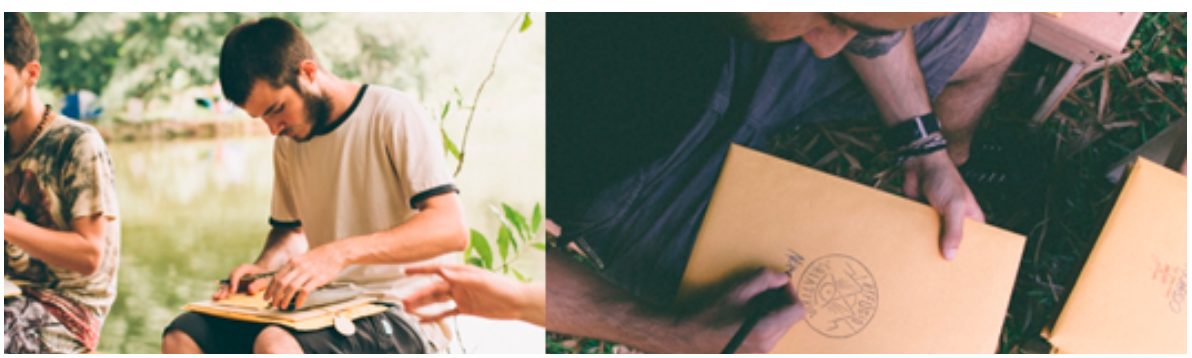

Fonte: Entremonte (estúdio de fotografia e vídeo)

De forma a tornar o momento o mais especial e íntimo possível, para que pudesse proporcionar uma entrega maior de cada participante, transformamos o momento em uma espécie de ritual, no qual utilizamos um 'bastão que fala' (baseado em tradições indígenas, aquele que detém o bastão tem a oportunidade de apresentar uma ideia enquanto os demais escutam, favorecendo as decisões democráticas, de maneira justa e imparcial).

De posse do bastão, o participante apresentava-se de forma livre, tendo como sequência o compartilhamento do seu artefato pessoal especial e o que foi chamado de 'exercício do choque'. Ao descrever um objeto especial para si, a pessoa, intuitivamente, começa a falar de si própria. Esse momento foi fundamental para que se criasse uma noção de grupo e de propósito, fundamentalmente necessários para uma melhor experiência durante o Refúgio Criativo, proporcionando uma maior entrega, fluidez e abertura no diálogo do grupo.

O lanche. Após do diálogo de autoconhecimento, realizamos um intervalo, no qual todos se dirigiram a outra área do terreno 
e compartilharam uma mesa com frutas e sucos. O objetivo era respirar e descontrair a conversa, proporcionando um momento de pausa após a etapa de apresentação, tendo em vista que muitos depoimentos foram intensos e emocionaram a todos. Destacamos a experiência estética de apresentação da alimentação, nos materiais dos utensílios e na forma como foram elaborados os pratos (Figura 5).

Figura 5 - apresentação da mesa
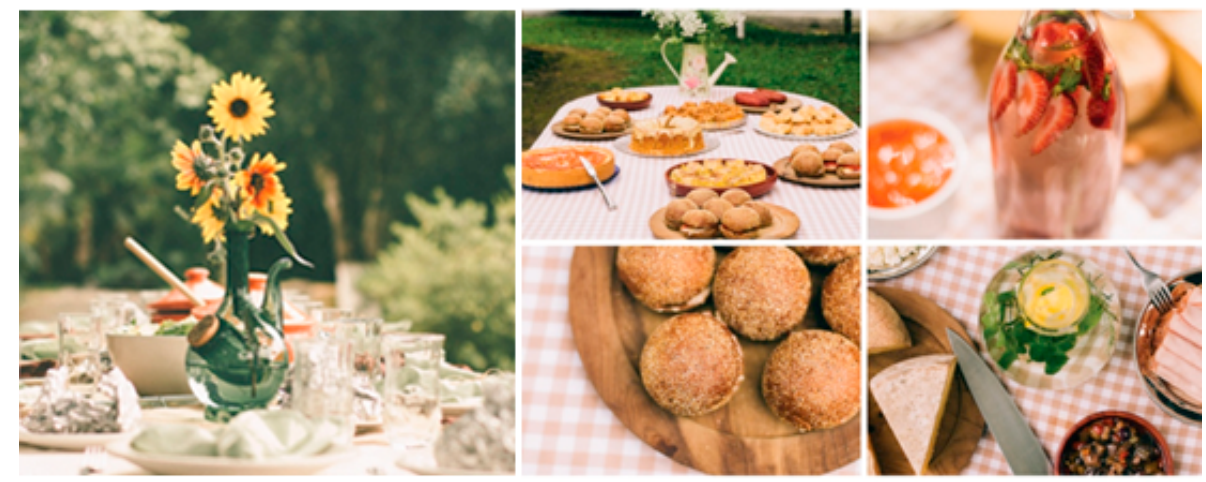

Fonte: Entremonte (estúdio de fotografia e vídeo)

Temáticas / oficina do futuro. O momento das temáticas talvez tenha sido um dos mais importantes do primeiro dia, devido à intensa troca de informações. Escolhemos um local confortável, sob uma árvore, de forma que todos pudessem sentar-se no chão e apoiarse para fazer anotações. O diálogo começou de forma livre, tendo dois dos participantes como mediadores (Miguel e Jackson), com a intenção de desenvolver e conversar sobre uma série de assuntos a partir de uma pergunta, como uma provocação inicial: 'considerando seu processo criativo, ferramentas de imersão, vivências pessoais, como você relaciona todo seu movimento pessoal e profissional com a ideia desse retiro imersivo?'. Esse compartilhamento permitiu que os participantes aprendessem com a experiência do outro; 
com os depoimentos individuais foi possível internalizar alguns pontos, refletindo sobre usos alternativos, correlações nas formas de trabalho e novas possibilidades de aprendizagem. Compartilhamos reflexões individuais acerca dos processos criativos, metodologias e ferramentas, desafios pessoais e profissionais, visão de mundo, valores, medos e futuro (Figura 6).

Figura 6 - Informações geradas no momento 4
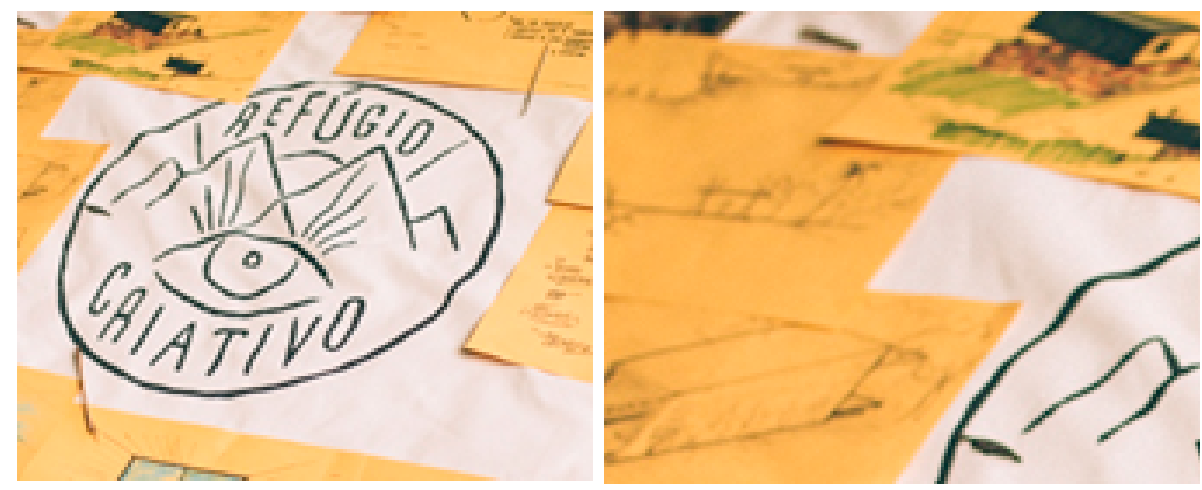

Fonte: Entremonte (estúdio de fotografia e vídeo)

O objetivo nesse momento foi exercitar o foco, dialogar abertamente sobre os processos criativos de cada um e observar pontos de concordância e divergência em cada realidade e área de trabalho, pois vindos de universos diferentes estaríamos iniciando o pensamento sobre um projeto colaborativo, aprendendo em conjunto, de maneira livre, expondo pensamentos.

Organizamos a oficina de trabalho para que os colaboradores discutissem suas experiências de vida e de trabalho (seus processos criativos e desafios) utilizando as tecnologias disponíveis no acampamento: depoimentos de experiências e sensações vividas (imagens e palavras para mostrar uma experiência relacionada a algo em seu passado), contação de histórias e leitura de textos, desenho à mão livre etc. Desse momento destacamos algumas palavras- 
chave, como: tempo escasso (no sentido do período de concepção dedicado aos projetos de cada empresa), linguagem expressiva (discussão entre ferramentas analógicas e digitais) e experiências imersivas (reconhecimento da relevância de experiências como o Refúgio Criativo para exercício do foco nos processos individuais).

Alimentação e depoimento. Logo após o momento das temáticas houve uma pausa para uma alimentação. No meio da tarde de sábado, a refeição caracterizou-se como um café colonial, com uma variedade grande de opções. Novamente o cenário foi outro, ainda inexplorado. Em conjunto, escolhemos o local para o café e o posicionamento da mesa comunitária para tal. Optamos pela acomodação próxima a uma antiga construção enxaimel localizada em uma colina do terreno. A atmosfera e o cenário contribuíram para uma conversa descontraída, na qual os assuntos permeavam o universo discutido nas temáticas, mas de uma forma mais descompromissada.

Ao término da refeição, ainda sentados à mesa, ocorreu um momento de depoimento pessoal. O designer Luís Fernando Leier relatou sua experiência com o universo da meditação e como isso influencia seu processo de trabalho. Leier desenha mandalas, que o colocam em contato com alguma esfera da criação, trazendo assim autoconhecimento e uma compreensão melhor a respeito do universo que o rodeia.

Naquele momento, o designer ampliou a discussão sobre os processos criativos, agregando um ingrediente mais holístico ao abordar temas do comportamento mental no processo criativo. Leier trouxe à discussão assuntos relacionados com expansão da consciência, pensamento, energia, conceitos sobre o tempo e o efêmero, criatividade e foco. Para ele, por meio da meditação é possível desenvolver a habilidade de ouvir a consciência, de observar seus 
pensamentos e sentimentos e expressar os sentidos, aprendendo a identificar e discernir o que é ego e o que é consciência e contribuindo para a autopercepção e a ação nas atividades do dia a dia. Em sua atividade, essa descoberta é traduzida sobre uma forma de desenho, que são as mandalas, que por sua vez são a tradução de um propósito. Ou seja, trata de direcionar energia, para que o pensamento organize essa energia e a manifeste em forma (desenho).

Leier também abordou a meditação e exercícios de respiração no nível da experiência como meio de relaxar o corpo e a mente para possibilitar o aprofundamento na nossa própria estrutura psicofísica e a descobrir novas dimensões internas que são canalizadas no ato de desenhar.

Fogueira e celebração. Já no fim do dia, foi realizado em outra parte do terreno, numa clareira, em um dos pontos mais altos do local. Em colaboração, procuramos a madeira necessária para a construção da fogueira e nos organizamos em forma de círculo ao redor do fogo.

Oato da fogueira foi um momento de interiorização do conteúdo exposto durante o dia todo. Foi um momento mais individual, de mais silêncio e pouco diálogo, de absorção e assimilação de tudo que foi conversado, de juntar os pontos que até o momento estavam se conectando e fazendo sentido para cada um (Figura 7). Mergulhar em tanta informação até aquele momento foi fundamental para organizar o pensamento para a tarefa do dia seguinte: projetar em conjunto um artefato arquitetônico. 
Figura 7 - A fogueira

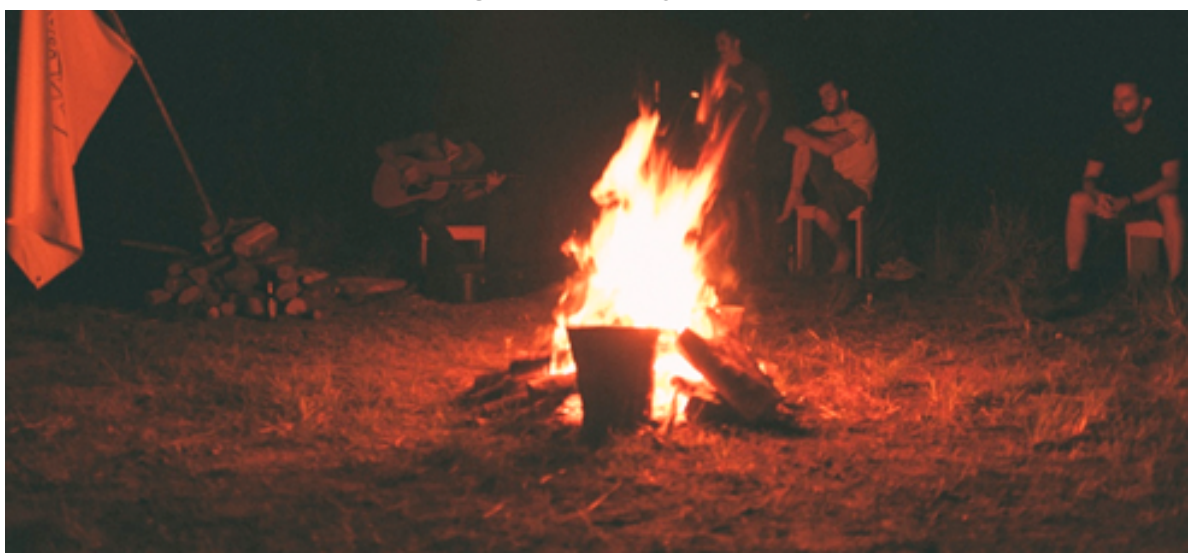

Fonte: Entremonte (estúdio de fotografia e vídeo)

A música ambiente permeou essa atividade, com uma trilha sonora mais experimental e meditativa, auxiliando na introspecção individual do participante. Horas mais tarde, ainda ao redor da fogueira, a trilha sonora deu lugar à participação de uma pequena apresentação ao vivo do músico Williard Ribeiro, com voz e violão. A essa altura um clima de celebração já começava a tomar forma, culminando, após a apresentação de Ribeiro, na preparação do jantar, no qual todos puderam auxiliar, de forma prática, na preparação do alimento, transformando mais uma vez o ato numa oportunidade para uma experiência sensorial única. Fim do primeiro dia.

\section{E no segundo dia...}

No segundo dia o Refúgio Criativo teve cinco momentos bem definidos que foram: oficina de coexploração, caminhada cognitivaexploratória e definição do lugar, almoço, prototipação e conclusão.

Oficina de coexploração. O segundo dia foi dedicado à ideação e prototipagem (aqui compreendida como atividade que se apoia em códigos gráficos para exploração, síntese e modelação verbal e 
gráfica do conceito) da cabana do Refúgio Criativo. Sentados ao redor de uma mesa ao ar livre, e com as ferramentas de trabalho expostas, iniciamos a troca de ideias e reflexões (Figura 8).

Figura 8 - Oficina de coexploração

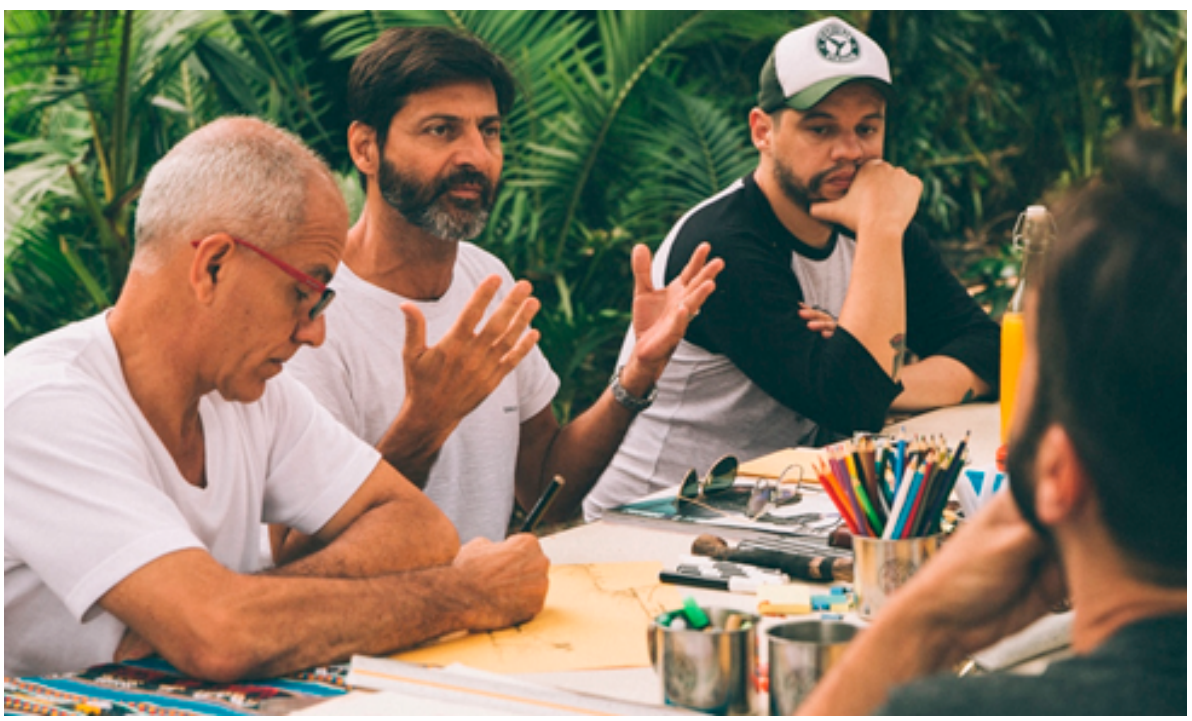

Fonte: Entremonte (estúdio de fotografia e vídeo)

Embora não se tenha pré-determinado de forma rígida uma ferramenta de trabalho para a atividade de grupo, a forma natural como o momento foi sendo conduzido levou para uma discussão mais orgânica e flexível, em que havia espaço para o inesperado e o imprevisível. Sendo assim, a utilização das técnicas de brainstorming e mapas mentais pareceram ser as mais adequadas, pois desenvolvemos naturalmente um fluxo livre de troca de ideias, de forma solta, imaginativa e sem limites ou censura, definindo associações, percepções e compreensões por meio de tentativa e erro. As ideias foram agrupadas para uma análise, crítica e viabilidade (Figura 9). 
Figura 9 - Oficina de coexploração
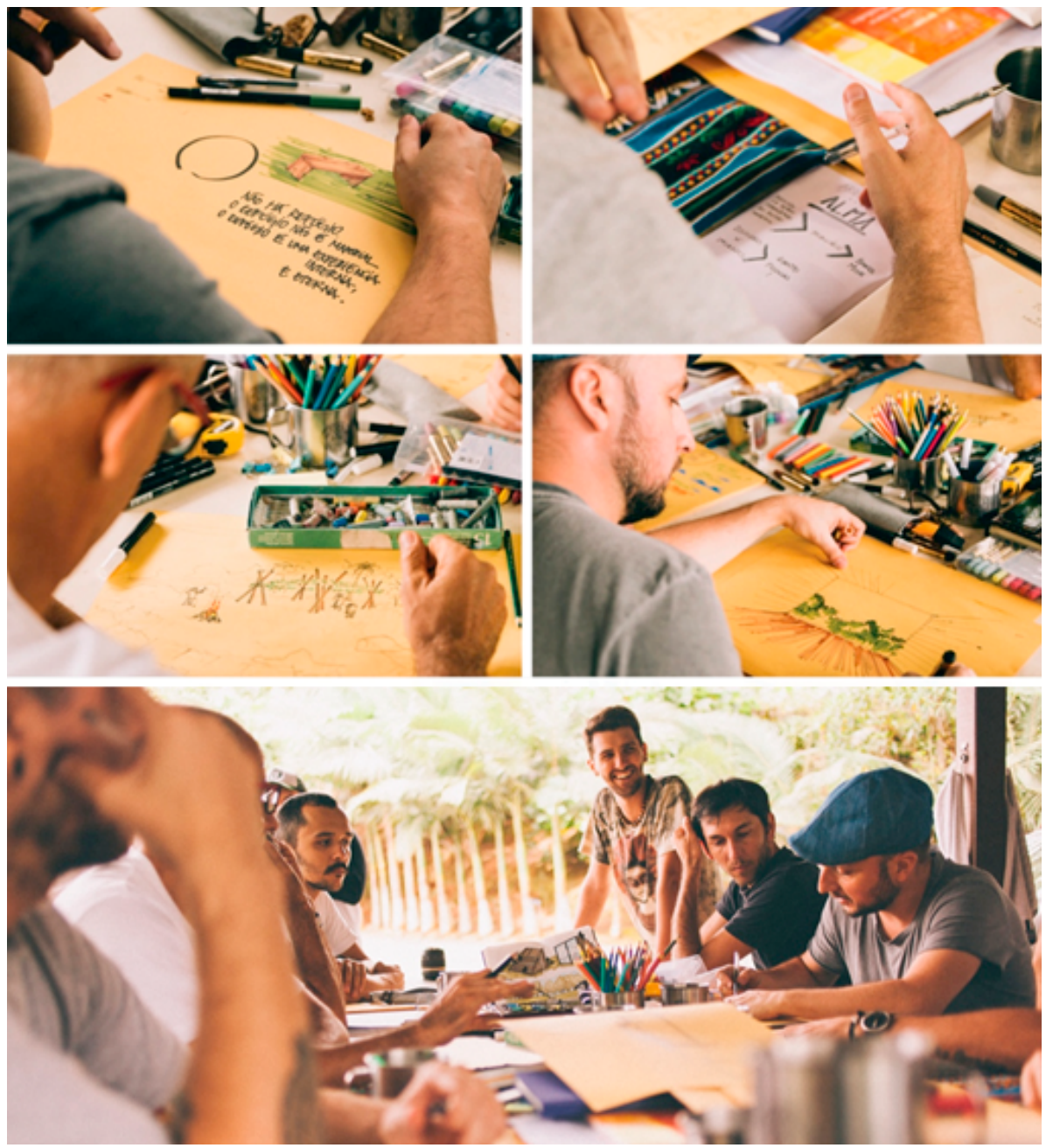

Fonte: Entremonte (estúdio de fotografia e vídeo)

Utilizamos basicamente o desenho à mão livre, ferramentas diversas de desenho (marcadores, lápis, giz pastel, etc.), leitura de textos e exploração de painéis semânticos/moodboards com imagens de inspiração, que permeavam trabalhos de arte, instalação, design e arquitetura (Figura 10). Os desenhos e os textos criavam aos poucos uma narrativa que trazia à discussão momentos de sessões 
de interpretação para perguntas como: o que é o Refúgio Criativo e o que ele significa para cada um? Quais são os objetivos do Refúgio Criativo? e quais são as necessidades do Refúgio Criativo? Que forma ele deve ter? Discutimos o problema e elencamos cenários de uso futuro (após executada a cabana) que foram sendo definidos. Destacamos os 'achados', aspectos perceptivos e atitudinais, visando etapas posteriores (figura 10).

Figura 10 - Sínteses gráficas e materiais utilizados na oficina de coexporação

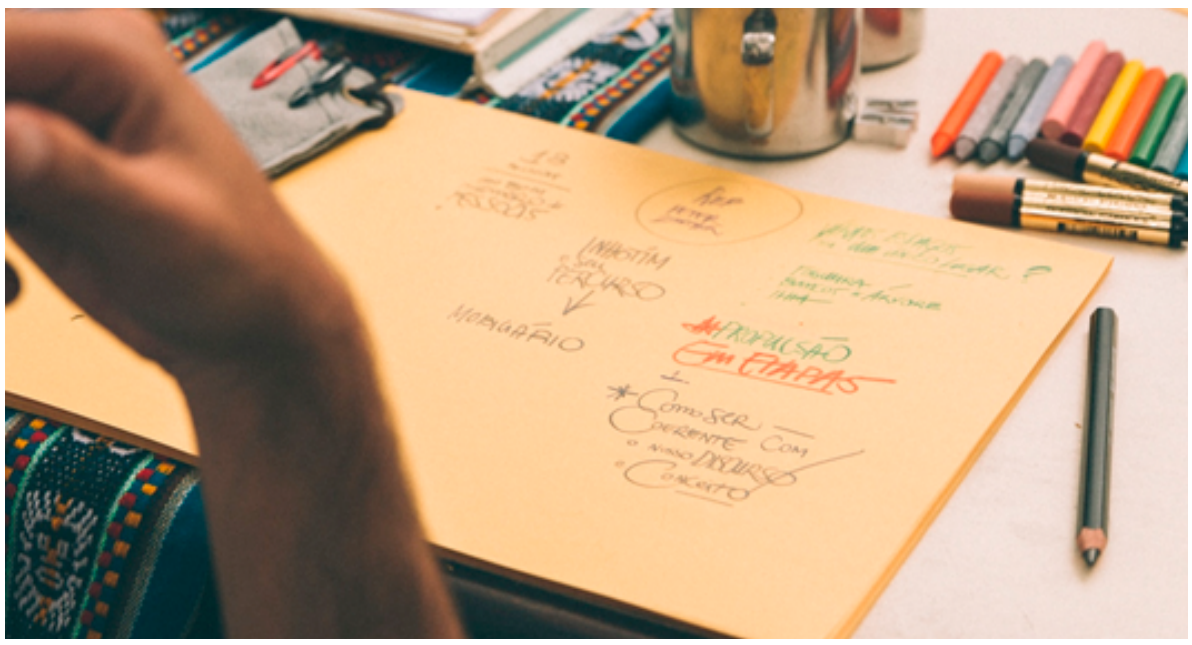

Fonte: Entremonte (estúdio de fotografia e vídeo)

Dessa discussão extraímos informações que podiam auxiliar na geração de soluções projetuais, considerando: a forma pela qual as pessoas vão utilizar o refúgio, o ambiente físico, o contexto de uso e emoção, percepções, valores estéticos, aspectos culturais.

Após a discussão sobre o tema, separamos algumas informações que foram agrupadas em categorias (uso, materiais, técnicas etc.) que possibilitaram o estabelecimento de relações entre conceitos e seu posterior refinamento; por último, foi realizada a triagem e conclusão (avaliação, proposição de soluções e síntese dos resultados). 
Essa atividade estendeu-se até o momento em que se alcançou um resultado de acordo com as necessidades e os objetivos. 0 conceito gerado como síntese levou em conta aspectos técnicos (materiais, técnicas construtivas, viabilidade financeira), aspectos funcionais (como seria a relação das pessoas no espaço) e aspectos estéticos (a forma da cabana).

Figura 11 - Croquis da geração de alternativas para o espaço Refúgio Criativo

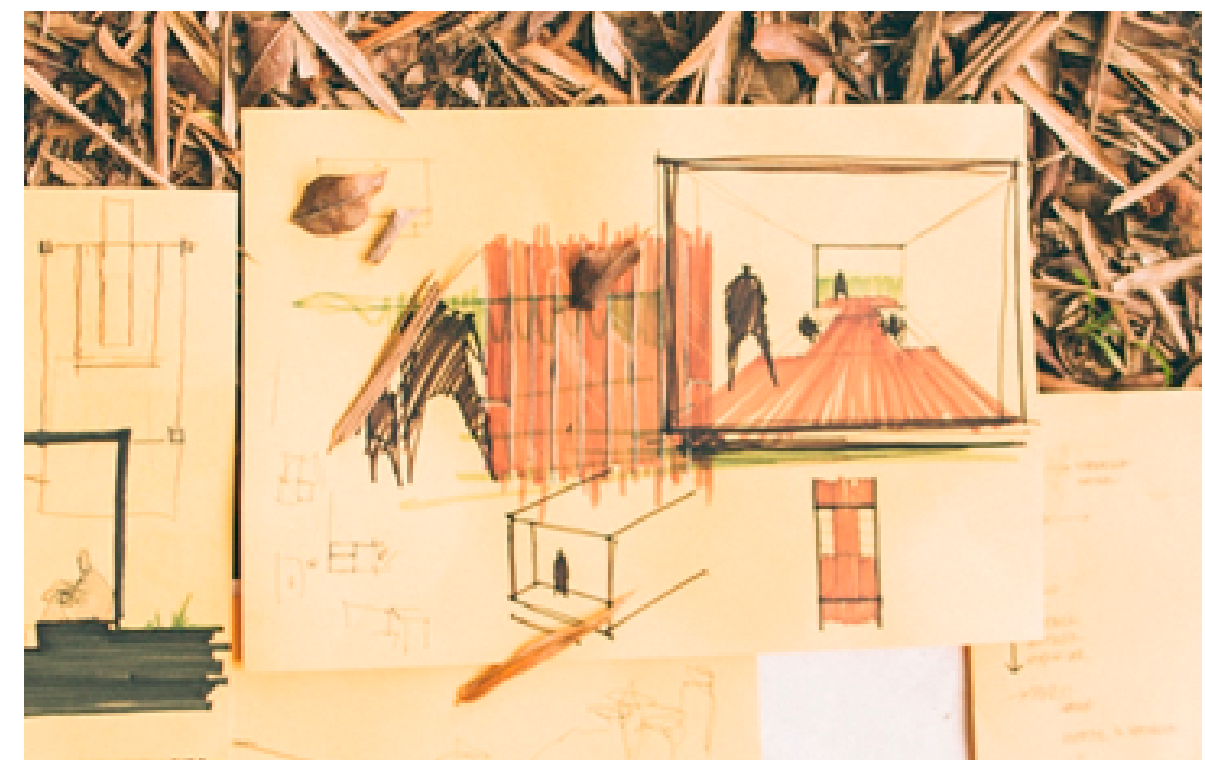

Fonte: Entremonte (estúdio de fotografia e vídeo)

Entre os resultados desse momento destacamos: (1) pensamento orientado para soluções criativas; (2) conhecer as opiniões dos envolvidos e determinar uma visão consensual do grupo sobre as questões discutidas (organização, estruturação, categorização, resumo e hierarquização dos dados qualitativos e pensamentos): (3) estabelecer relação com os conceitos levantados durante as observações ao longo dos dois dias do workshop Refúgio Criativo. 
Caminhada cognitivo-exploratória e definição do lugar. Após uma primeira rodada de discussão e levantamento de alguns pontos partimos para a segunda caminhada pelo terreno (Figura 12), a fim de reconhecer melhor o local para construção do refúgio, produzindo novos subsídios para o projeto, como implantação, orientação, estratégias visuais, topografia, insolação, ventos dominantes, relação com entorno e acesso ao local. Ou seja, itens intrínsecos à definição de um partido arquitetônico, que, entretanto, no desenvolvimento deste trabalho, ficou em segundo plano. Verificamos aqui que o processo e abordagem interdisciplinar na conceituação do projeto foi mais importante que alguns dos aspectos de discussão de um partido arquitetônico, como a situação da obra no terreno.

Figura 12 - Caminhada cognitivo-exploratória pelo terreno

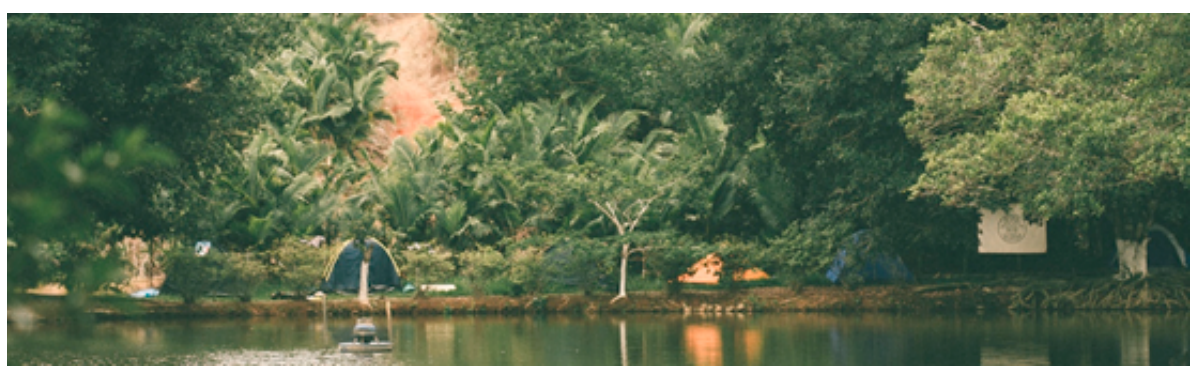

Fonte: Entremonte (estúdio de fotografia e vídeo)

Almoço. A pausa para o almoço foi estratégica para dar um certo distanciamento do tema e digerir os pontos que conseguimos elencar até aquele momento. Sentados novamente ao redor de uma mesa comunitária ao ar livre, conversamos de forma mais amena sobre as descobertas e surpresas a que havia se chegado.

Prototipação. Após o almoço, foi o momento para validação e refinamento das ideias e sinapses produzidas, do que foi discutido, materializado e desenhado nas fases de ideação. A mesa comunitária 
foi utilizada como base para de trabalho e suporte de materiais para 'desenhar' em conjunto o que seria o Refúgio Criativo, avaliando os painéis semânticos/moodboards, rascunhos, desenhos, maquetes e tudo o que foi considerado interessante materializar por meio do processo de cada um (Figura 13). Havia uma preocupação importante com uma mesa grande, onde todos pudessem trabalhar juntos e não separados em grupos.

Figura 13 - Resultado do momento da prototipação

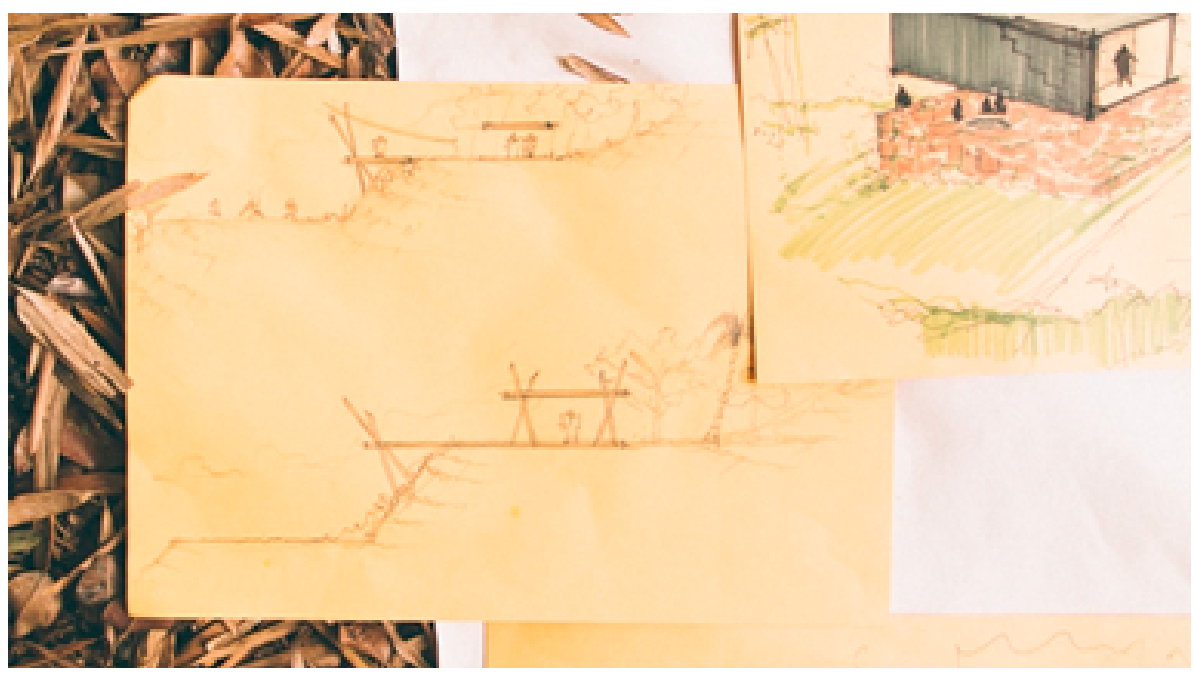

Fonte: Entremonte (estúdio de fotografia e vídeo)

Fechamento. No fim da tarde do segundo dia, sentados novamente em roda, próximos ao bambuzal e utilizando os bancos individuais, aconteceu a conclusão desse processo prático, com a discussão de possíveis caminhos com o Refúgio, ou seja, dentro de todas as opções, que rumos o projeto poderia seguir. Para isso foi organizado um painel semântico/moodboard com os caminhos mais interessante e foram elencadas tarefas importantes a serem realizadas como, próximos passos entre cada participante ou empresa, como 
por exemplo, detalhamento do projeto executivo de arquitetura e memorial descritivo do projeto, orçamento da obra, decupagem dos registros de imagens e vídeos, relação das anotações de cada participante realizadas ao longo do workshop e refletir sobre os desdobramentos (objetivos e subjetivos) futuros.

O fechamento do Refúgio Criativo ocorreu com o compartilhamento do que foi a experiência, em um panorama geral, para cada participante e com o estabelecimento dos próximos passos, considerando cronograma e planejamento dos materiais de comunicação da experiência projetual do Refúgio Criativo.

\section{DESDOBRAMENTOS SUBJETIVOS E OBJETIVOS E REFLEXOS DA EXPERIÊNCIA}

A reflexão produzida durante o Refúgio Criativo permitiu mergulhar mais profundamente nos próprios pensamentos (confrontando-os ao mesmo tempo com os demais participantes) e, o ato de acompanhálos, aprimorou a habilidade expressar as ideias dentro do processo, de uma forma mais simples e natural. Com a experiência foi possível descobrir um novo olhar para a vida, acessar o outro e a si próprio. A entrega à vulnerabilidade e ao risco da exposição foram ampliados. Diálogos foram incentivados e mesclados pelo silêncio, trazendo à tona as questões importantes debatidas no Refúgio Criativo. Outros desdobramentos subjetivos foram estruturados por nós em tópicos: 'sobre as fronteiras entre Arquitetura e Design'; 'sobre o uso do desenho', 'sobre atitudes inter e intrapessoais e os processos de colaboração/ participação', 'o resgate da criatividade pessoal e da atenção'. Em uma síntese produzida ao fim do workshop definimos a experiência como 'o Refúgio foi construído dentro de cada um de nós' (Figura 14). 
Figura 14 - Representação do significado do Refúgio Criativo para o grupo

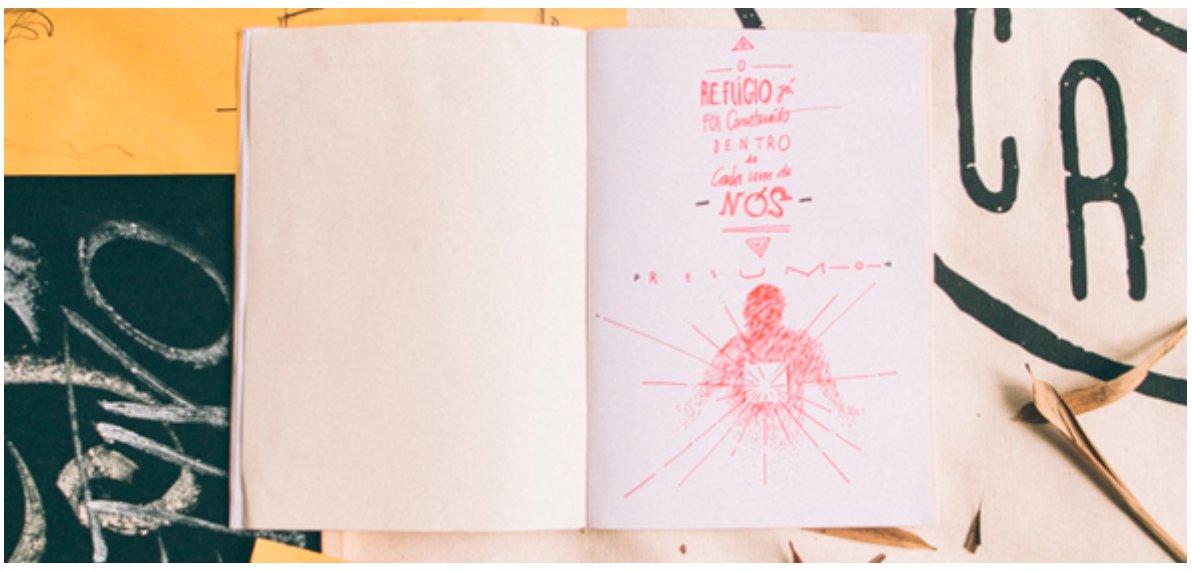

Fonte: Entremonte (estúdio de fotografia e vídeo)

Já os desdobramentos objetivos estruturamos nos seguintes tópicos: 'sobre as afinidades entre Arquitetura e Design para o projeto da cabana'; 'sobre a identidade do Refúgio Criativo', 'sobre textos e depoimentos pessoais', sobre as estratégias de disseminação de conteúdo', sobre as imagens do registro', 'sobre outras mídias impressas ou digitais', sobre o site do Refúgio Criativo', 'sobre o ponto de vista pessoal e profissional das empresas participantes do workshop'.

Os reflexos do Refúgio Criativo na Metroquadrado tonaramse mais evidentes nos meses subsequentes à realização do refúgio. Desde então, uma série de reuniões informais e workshops internos da equipe do escritório foram realizados. Ao mesmo tempo, paralelamente e de forma fluida e orgânica, ocorreram uma série de ações externas ao dia a dia do escritório, que reuniam representantes daliderança da Metroquadradoe alguns profissionais participantes do Refúgio Criativo, fundamentalmente os sócios do estúdio Firmorama. Basicamente, tratou-se de encontros que tiveram como objetivo dar 
continuidade às reflexões oriundas daquele experimento imersivo, procurando elucidar novos rumos para ambas as empresas, com base nos cruzamentos entre a realidade (e limitações) das empresas e as atividades teóricas e práticas de imersão do workshop Refúgio Criativo, principalmente evidenciando os pontos de contato entre arquitetura e design nos processos de cada empresa. 


\section{REFERÊNCIAS}

ABELLÁN, M.; AGREST, D. Ephemeral. Barcelona, Monsa, 2014.

BISELLI, Mario. Teoria e prática do partido arquitetônico. Disponível em: <http://www.vitruvius.com.br/revistas/read/ arquitextos/12.134/3974>. Acesso em: 11 jul. 2014.

BROWN, T. Design Thinking: uma metodologia poderosa para decretar o fim das velhas ideias. 3. ed. Rio de Janeiro: Elsevier, 2010.

CROSS, N. Desenhante: o pensador do desenho. Santa Maria: SCHDs. 2004.

DORNBURG, J. S. Arte y arquitectura: nuevas afinidades. Barcelona: Gustavo Gili, 2002.

FIRMORAMA. Disponível em: <http://www.firmorama.com/sobre>. Acesso em: 09 mar. 2015.

GOMES, L. V. Criatividade: projeto, desenho, produto. Santa Maria: sCHDs, 2001.

KAHN, L. I. How Im Doing, Corbusier. (1972). In: LATOUR. Alessandra (ed.). Louis I Kahn. Writings, Lectures, Interviews. Nova lorque: Rizzoli, 1991, pp. 297-312.

. The Profession and Education, In: WURMAN, Richard Saul. What Will Be has Always been. Nova lorque: Rizzoli, 1986, p.92.

. Signature Against the Sky (1967). In: Eye on Art "Signature agaist the sky", a portrait of Louis I. Kahn, architect. produção de WCAU-TV Philadelphia. 
. Forma e design. ( $1^{\circ}$ ed.). Tradução: Raquel Peev. 1. ed.São Paulo: Martins Fontes, 2010.

MAHFUZ, E. Reflexões sobre a construção da forma pertinente. Disponível em: <http://www.vitruvius.com.br/revistas/read/ arquitextos/04.045/606>. Acesso em: 11 juL. 2014.

Arquitetura é Arte? Revista Summa, Buenos Aires, n. 134, p. 128, mar. 2014.

MEDEIROS, L. M. S. Desenhística: a ciência da Arte de projetar desenhando. Santa Maria: sCHDs, 2004.

NACCACHE, A. (Org.). Criatividade brasileira. Barueri: Manole, 2013.

OSTROWER, F. Criatividade e processos de criação. Petrópolis: Vozes, 2013.

PALLASMAA, J. Os olhos da pele: arquitetura e os sentidos. 2. ed. Londres: Academy Press, 2005.

PIRONDI, C. Um desenho sobre as incertezas. Revista Móbile, São Paulo: CAU/SP, n. 1, p. 29, jun. 2014.

RONNER, H.; JHAVERI, S.; VASELLA, A. Louis I. Kahn: complete works, 1935-1974. Basel: Birkhäuser, 1977.

SANTA ROSA, J. G.; MORAES, Anamaria de. Design participativo. 1. ed. Rio de Janeiro: Rio Books, 2012.

SEGAWA, H. Saberes e fazeres na arquitetura. Revista Móbile, São Paulo: CAU/SP, n. 1, p. 28, jun. 2014.

SANDERS, E. B.; BRANDT, E.; BINDER, T. A framework for organizing the tools and techniques of Participatory Design. Sydney, Austrália: Artigo, 2010. 
SANDERS, E. B. From user-centered to participatory design approaches. In: FRACARA, J. [colocar o nome por extenso] (Ed.). Design and the social sciences. [local de publicação]: Taylor \& Francis Books Limited, 2002. Disponível em: <http://maketools.com/articlespapers/FromUsercenteredtoParticipatory_Sanders_\%2002.pdf >. Acesso em: 10 dez. 2014.

Prototyping for the design spaces of the future. 2013. Disponível em: <http://www.maketools.com/articles-papers/ Sanders2013Prototyping.pdf>. Acesso em: 05 out. 2014.

.Information, inspiration and co-criation. In: CONFERENCE OF THEEUROPEANACADEMYOFDESIGN,6.,2005,Alemanha:Universidade de Artes de Bremen, 2005. Disponível em: <http://www.maketools. com/articles-papers/InformationInspirationandCocreation_ Sanders_05.pdf>. Acesso em: 16 set. 2014.

SANDERS, E. STAPPERS, P. Co-cration and the new ladscapes of design. In: CoDesign, Taylor \& Francis, 2008. Disponível em: <http:// journalsonline.tandf.co.uk>. Acesso em: 05 out. 2014.

TAVARES FILHO, A. C. Transições entre os planos conceitual e material da concepção arquitetônica em Louis I. Kahn. Disponível em: <http://www.arquiteturarevista.unisinos.br/index. php?e=7\&s=9\&a=46>. Acesso em: 7 jul. 2014.

VIANA, M.; VIANNA, Y.; ADLER, I.; LUCENA, B.; RUSSO B. Design thinking: inovação em negócios. Rio de Janeiro: MJV Press, 2012. 162 p.

ZUMTHOR, P. Pensar a arquitectura. Barcelona: Gustavo Gili, 2009. 



\section{A linguagem visual e a percepção: um estudo de caso em crianças}

Eloah Maria Oliveira Acauan (Currículo Lattes) João Eduardo Chagas Sobral (Currículo Lattes)

\section{INTRODUÇÃO}

O design atua, enquanto linguagem visual, com um conjunto de orientações acerca do uso e do desenvolvimento de elementos imagéticos em suas mais diferentes configurações. Em contrapartida, encontra-se o processo de visualização. Assim como todo o processo de aprendizagem, a percepção visual é dependente do contexto sóciocultural ao qual está inserida. São os agentes culturais os maiores modificadores da percepção e, portanto, da linguagem visual. A partir disso, alguns questionamentos desenvolvem-se: serão efetivas as orientações da linguagem visual criadas em uma época e aplicadas em outra? Será a percepção orientada pelas teorias visuais 
aplicadas ou pelos agentes culturais? Tais teorias respeitam aspectos sociais e culturais em um processo dinâmico? Ou, ainda, até que ponto as orientações transmitidas dentro do campo do design, em relação à visualidade, são efetivas com o passar dos anos?

O presente artigo busca algumas possíveis respostas ao analisar, por meio da pesquisa experimental, aspectos da linguagem visual em crianças menores de 5 anos. Essa análise utiliza, como elemento visual analisado, a fotografia.

A escolha pela fotografia caracteriza-se por sua natureza muito próxima ao referente, diferentemente de outras configurações visuais como o desenho ou a representação gráfica (dependentes e extremamente variáveis conforme época e região). Essa proximidade tende a facilitar o reconhecimento dos processos perceptíveis.

Entretanto, sendo a fotografia um produto cultural e o indivíduo fruto das relações com o meio (VYGOTSKY, 2010) como buscar os processos perceptivos mais pessoais, ainda não moldados pelo contexto cultural? A criança, em suas relações iniciais com a sociedade e os processos perceptivos, representa um usuário em potencial.

A linguagem visual, para a criança, exerce forte representatividade nas relações com o mundo que a cerca e, embora as pesquisas a respeito do processo de desenvolvimento da inteligência no indivíduo sejam bastante exploradas, pouco se conectam com as relações da imagem e da visualidade.

É por meio do olhar analítico de Vygotsky (2010) que o aprofundamento das relações psicológicas estabelecidas na criança e suas particularidades enquanto indivíduo ficam evidentes. As definições de método e de recorte, relacionados à idade das crianças estudadas, também derivam das observações do autor. 
Durante o processo de estruturação do objeto de estudo tornou-se evidente o enorme universo abordado pela visualidade, impondo, assim, à pesquisa um necessário e expressivo recorte de estudo. A fim de promover reflexões mais aprofundadas acerca do objeto de estudo julgou-se adequado centrar a investigação em dois teóricos consagrados por suas contribuições na área da linguagem visual, quais sejam, Rudolf Arnheim e Donis A. Dondis.

Arnheim (2013) volta-se aos processos de percepção da forma e da linguagem visual relacionados à psicologia da Gestalt. Donis, por sua vez, orienta sua pesquisa a partir da necessidade do desenvolvimento de um alfabetismo visual, em especial após o advento da fotografia, desenvolvimento da câmera e seus desdobramentos.

O presente estudo, portanto, volta-se ao breve relato da pesquisa experimental aplicada e à discussão dos resultados obtidos durante o processo de pesquisa, não julgando apropriado adentrar as bases teóricas ou decisões metodológicas. Apresentando, portanto, apenas duas subdivisões: (I) a coleta de dados e (II) as análises.

\section{A COLETA DE DADOS}

A coleta de dados foi estruturada a partir do desenvolvimento do instrumento de pesquisa ${ }^{1}$ e das decisões que orientaram o processo metodológico. É importante ressaltar que a pesquisa aplicada apresenta natureza experimental, embasada nos processos

\footnotetext{
${ }^{1}$ As especificidades acerca do desenvolvimento do instrumento de pesquisa e definições sobre o processo metodológico estão constantes na macropesquisa da qual desdobra-se este estudo, "As percepções do olhar: uma análise experimental da linguagem fotográfica em crianças".
} 
de investigação de Vygotsky e adaptados por meio do design às necessidades do objeto de pesquisa aqui relatado.

Os recortes das teorias visuais de Arnheim e Dondis apresentam sua maior contribuição para a construção dos parâmetros de análise e, por fim, as reflexões de Vygotsky orientaram a escolha da amostra ${ }^{2}$ e suas especificidades.

Nesta pesquisa busca-se desvelar relações estabelecidas entre o indivíduo e a percepção visual em um contexto de menor influência social e por consequência também dos processos visuais prémoldados culturalmente; por esse motivo, selecionou-se crianças em fase pré-escolar como objeto, considerando nessa decisão a premissa de Vygotsky (1998), que destaca que em um experimento que exige a compreensão da orientação oral expressa pelo pesquisador e a tomada de decisão diante de uma situação-problema não pode ser efetuada por indivíduos não possuidores de maturidade fisiológica necessária a essas operações. Portanto, acredita-se que a intersecção entre a menor influência social possível, inclusive da cultura midiática ${ }^{3}$, e a capacidade de estabelecer conexões lógicas que viabilizem o experimento ocorrem no período piagetiano chamado Pré-Operatório. Por se tratar de um estudo de caráter qualitativo, julga-se mais apropriado restringir o grupo estudado a crianças entre 2 e 3 anos de idade.

\section{O EXPERIMENTO}

O experimento consistia em uma bateria de sete escolhas relacionadas a alterações de seis elementos da linguagem visual:

\footnotetext{
${ }^{2}$ Aceita-se como amostra a mesma definição desenvolvida na macropesquisa: 12 crianças, de ambos os sexos, frequentadoras de Centros de Educação Infantil na cidade de Joinville, com idades de 2 a 3 anos.

${ }^{3}$ Considera-se, para este estudo, a cultura midiática como um grande núcleo da influência de imagens produzidas com fins psicológicos de orientação comportamental.
} 
referente (objeto representado), cor, nitidez, enquadramento (localização do objeto dentro do quadro da imagem), fotometria (relação da iluminação da imagem), ponto de vista (ângulo de visualização do objeto) e relação parte/todo (quanto do objeto era representado na imagem). Tais elementos foram obtidos por meio do cruzamento das teorias de Dondis (1997) e Arnheim (2013). Cada grupo apresenta cinco variáveis do mesmo elemento, apresentado referentes reais ${ }^{4}$ representados fotograficamente (por meio de fotografias).

Cada escolha, portanto, correspondia a um grupo de cinco fotografias apresentadas à criança em um único suporte, distribuídas de forma a gerar a menor influência possível no processo de escolha. O suporte tinha o formato circular por, seguindo a teoria da Gestalt, gerar continuidade e não indicar início e/ou fim, minimizando interferências no processo perceptivo.

A primeira escolha corresponde ao referente, já que é necessário estabelecer um vínculo entre a criança e o elemento observado para que não haja perda de interesse durante o processo de pesquisa. Da mesma forma que Vygotsky (2010) relaciona a experiência com o brinquedo como o meio para satisfazer as necessidades imediatas de uma criança pequena, a escolha do referente da fotografia permite à criança satisfazer algum desejo. Essa primeira escolha influencia os outros seis grupos de escolha. Os referentes oferecidos ao indivíduo são a bola, o gato, a colher, a mulher e um elemento da cultura midiática popular (Galinha Pintadinha), os referentes são apresentados, respectivamente, na Figura 1 a seguir:

\footnotetext{
${ }^{4}$ Julga-se mais adequada a utilização de um referente ao real pela relação denotativa e mais próxima à visualização "natural" do mundo, estabelecida pelo sentido da visão.
} 
Figura 1 - Referentes apresentados à criança na primeira etapa
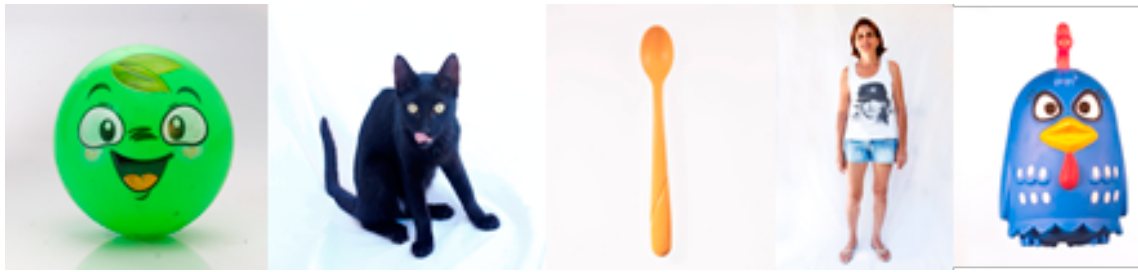

Fonte: primária

A segunda escolha, realizada pela criança, se refere a cor e não apresenta influência nos outros cinco grupos. Essa escolha contém apenas duas variáveis: a presença ou não da cor na imagem. As opções propostas às crianças apresentam como resultado uma sequência de sete escolhas.

As fotografias usadas no experimento foram apresentadas no formato impresso e reveladas em papel fotográfico, a fim de preservar seu caráter de realidade, bem como a qualidade da imagem; foram dispostas sobre suporte rígido redondo, conforme Figura 2 a seguir, e no formato $10 \times 15 \mathrm{~cm}^{5}$. Em pró da unidade imagética do experimento, optou-se por desenvolver as fotografias em estúdio, especificamente para a pesquisa, evitando assim o uso de imagens de bancos de dados ou internet.

\footnotetext{
${ }^{5}$ A escolha do tamanho da fotografia impressa se deu seguindo a orientação de um material grande o suficiente para que os detalhes sejam identificados, mas não tão grande a ponto de resultar em um grupo (disco com cinco fotografias) grande demais para sua completa visualização pela criança.
} 
Figura 2 - Disco utilizado como instrumento de pesquisa

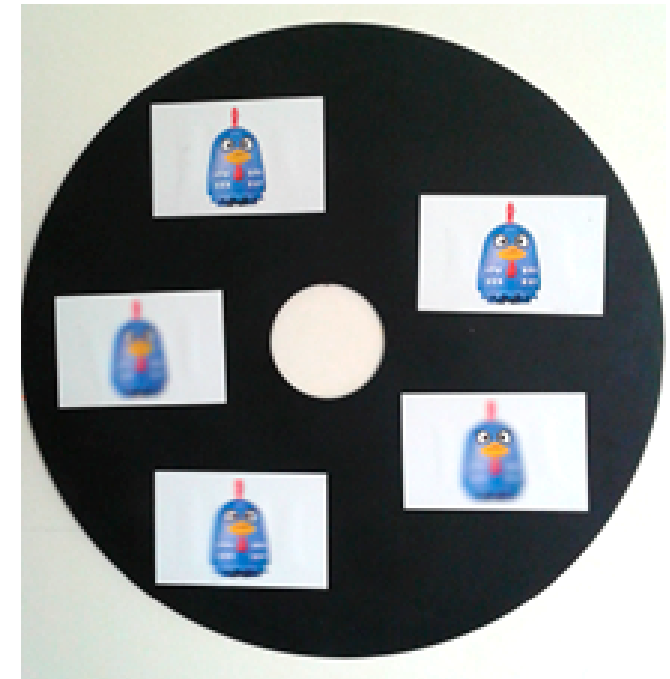

Fonte: primária

Optou-se em manter como fator condicionante à neutralidade do experimento a utilização do mesmo referente ao real em todas as fotografias. Já em relação à linguagem fotográfica, julga-se mais apropriado trabalhar um elemento a cada escolha, a fim de não prejudicar a análise e o processo de seleção desenvolvido. Tal qual a equipe de Vygotsky (1998), confronta-se a criança de 2 a 3 anos com a tarefa de escolha de uma das fotografias do grupo: o processo gradual de escolha, com a apresentação dos elementos separadamente e dependentes da escolha anterior, representa o equivalente caminho evolutivo dentro do processo da visualidade ${ }^{6}$.

Éimportante ressaltar que o tempo de aplicação do experimento foi parametrizado de acordo com a capacidade do público em reter a atenção a uma única tarefa. Por meio do grupo-teste percebeu-

${ }^{6}$ Esse caminho evolutivo é pautado no processo de desenvolvimento de uma imagem: referente, cor, ângulo, nitidez, enquadramento, luminosidade e quantidade visível do asunto. 
se a necessidade de limitar a duração de todo o experimento a 15 min de duração, tempos superiores cansavam o indivíduo e traziam resultados inseguros, já que era necessária uma retomada do processo de escolha.

Por tratar-se de uma pesquisa aplicada com seres humanos, foi submetida e aprovada pelo comitê de ética. O processo de pesquisa foi dividido em três dias de aplicação. No primeiro, desenvolveu-se o grupo-teste - constituído por 5 crianças, com idades entre 2 e 4 anos, de ambos os sexos e de turmas diferentes. $O$ grupo de teste identificou a necessidade de ajustes no processo metodológico.

Para a análise dos resultados, as considerações relevantes e escolhas desenvolvidas pelas crianças foram anotadas ao fim de cada etapa. Além disso, viu-se a necessidade da gravação do experimento em vídeo, já que o processo de escolha em crianças, evidencia Vygotsky (2010), está orientado pelo movimento e não só pelo resultado. Julgou-se ainda relevante a presença de um dos pais ou da professora, a fim de tranquilizar a criança e permitir o desenvolvimento da coleta de dados.

\section{OS PARÂMETROS E AS ANÁLISES}

Para o desenvolvimento da fase de análise dos dados coletados foram estabelecidos o uso de oito parâmetros ${ }^{7}$. No entanto, por tratarse do relato de uma parte da macropesquisa, julga-se apropriado apresentar apenas cinco destes. Os oito critérios utilizados foram (I) meio social, (II) cultura midiática, (III) objeto fotográfico, (IV) limites físicos, (V) contraste, (VI) preferência da cor, (VII) relação da

\footnotetext{
${ }^{7}$ Tais critérios correspondem a indicadores oriundos dos conteúdos teóricos levantados a partir das reflexões de Dondis (1997) e Arnheim (2013).
} 
tridimensionalidade e (VIII) percepção da nitidez. Os parâmetros reportados neste artigo são:

\section{Objeto fotográfico}

Observou-se com o experimento que a percepção do objeto fotográfico sofreu alterações durante a bateria de escolhas em 33,33\% das crianças estudadas.

Em alguns casos, a criança percebia ora o que estava representado na fotografia (referente), ora o conjunto de elementos visuais que a compunha. No segundo caso, a criança costumava descrever o elemento visual que lhe chamava atenção: "essa escura", "essa cinza", "essa grandona".

Outro fato interessante diz respeito à memória: quando o referente era identificado, e não suas características visuais, a atenção da criança volta-se aos processos subjetivos que esse referente despertava, com base na sua experiência. Por exemplo, numa das escolhas do referente gato a criança não visualizou as variações de nitidez apresentadas pela etapa, mas o gato muito parecido com o seu animal de estimação. A fotografia, nesse caso, corresponde à descrição de Dubois (1993) do 'espelho do real' e é por meio da sua forte semelhança com o objeto que a criança confunde a representação com o objeto.

Ainda em relação à experiência de vida, fatores como idade e personalidade mostraram-se relevantes e fortes moldadores da percepção. Indivíduos com idade próxima a 25 meses não demonstravam ter a capacidade de identificar alterações nos elementos visuais, as opções apresentadas no experimento representavam cinco formas diferentes do mesmo referente, tornando o processo de colagem do adesivo mais interessante que o processo de análise da linguagem visual. Talvez esse fato possa 
ser explicado pelo início do raciocínio técnico nessa fase citado por Vygotsky (1998): criança está no princípio do desenvolvimento da inteligência e da resolução de problemas.

Já em relação à personalidade, crianças com traços de hiperatividade tendiam a trocar os referentes no meio do processo de escolha, mas sem ignorar as alterações da linguagem visual. Ou seja, elas desenvolviam a análise dos elementos visuais sem, necessariamente, dependerem da visualização do mesmo referente. O processo de comparação de diferenças parecia mais fácil e dinâmico.

Deve-se considerar, ainda, que a percepção do referente pode se dar a partir da percepção da cor e da configuração da fotografia apresentada. Se a configuração, como cita Arnheim (2013), favorece a percepção do referente como um todo e não como um conjunto de elementos, o referente deve ficar mais aparente. A percepção da linguagem visual se dá caso a apresentação do referente (escolha do ângulo, enquadramento, plano, relação figura/fundo e contraste) ou sua própria configuração (cor e forma) apresentem formulação que prioriza a segregação do objeto em elementos. Entretanto, ainda é o indivíduo, dentro das suas funções psíquicas influenciadas pela sua bagagem, que determina a prioridade de percepção identificando a fotografia (elementos visuais) ou objeto (referente).

\section{Limites físicos}

Grande parte das orientações de linguagem fotográfica observa os limites físicos dos objetos, sua relação espacial e o próprio limite do quadro fotográfico. Todos os elementos e variações da composição partem do quadro e seu limite como base para qualquer desenvolvimento visual. Considerando ainda que cada etapa relacionava um grupo de fotografias e, para tal, constituía limites 
físicos para a percepção do grupo, busca-se compreender de que forma as crianças percebiam e interpretavam esses limites. Algumas crianças ao colar o adesivo o faziam em cima do referente. Outras, dentro dos limites físicos da fotografia, mas fora deste.

Para as que colavam o adesivo fora da fotografia, houve percepção dos seus limites físicos como algo que não poderia ser interferido, como um quadro em uma parede. $O$ suporte, nesse caso, representava área de livre interferência.

Enquadramentos diferenciados, com concentração do assunto em um dos terços (16,66\% das escolhas) ou no ponto de interesse $(41,66 \%)$ podem indicar uma preferência pelo dinamismo, movimento e minimalismo. Dentro da fotografia, esses enquadramentos são aplicados a fotografias mais atraentes, diferenciadas e que necessitem da ênfase em alguns pontos da imagem.

Já o enquadramento central do assunto, compatível com a estabilidade no centro do esqueleto estrutural de Arnheim (2013), foi a preferência identificada em apenas $25 \%$ das opções.

\section{Contraste}

O contraste, em uma fotografia, é constituído pela diferença entre o conjunto de altas luzes e pretos absolutos; quanto maior essa diferença, maior torna-se o contraste. Tudo, nesse caso, é dependente da luz incidente no objeto fotografado. A tonalidade de uma imagem, sua claridade, saturação ou alterações de cor são provocadas pela iluminação que recebem. Tais características apresentam-se como pessoais e mutáveis, variando de acordo com o momento e a bagagem cultural do indivíduo que as recebe.

A fotografia apresenta um norteador central, com cor, tom, fotometria e contrastes baseados no cinza médio 18\%. Aplica-se, aqui, o mesmo princípio do tom de Dondis (1997): é a relação com 
o objeto próximo, em uma imagem, que define se este é claro ou escuro. Naturalmente, um indivíduo pode concordar ou discordar dessa estimativa, optando por imagens supersaturadas, altos contrastes ou subexposições.

Apenas $25 \%$ da população estudada preferiu a fotometria pautado no cinza médio $18 \%$. Ou seja, pela teoria visual, apenas $25 \%$ teriam percepção dita adequada.

Entretanto, devem ser considerados aqui fatores extras, como acuidade visual e saúde das células responsáveis pela captação da luz e cor (cones e bastonetes). As crianças de menor idade oscilaram entre fotometria ideal (contraste médio) e supersaturado (baixo contraste para o claro). Uma das possíveis inferências é a imaturidade do globo ocular e, portanto, de suas células. Pode haver uma necessidade de maior incidência de luz para visualizar a mesma imagem.

Já os 33,33\% que optaram pela imagem subexposta podem tê-la feito em vista do aumento de pretos na imagem e, consequentemente, de contornos mais fortes na imagem. A fase dos 2 aos 3 anos é marcada pela iniciação nas artes da pintura, desenho e escrita, todas apresentando o traço bem definido.

Uma explicação possível para os $16,66 \%$ (duas crianças) que optaram pela fotografia saturada e os $8,33 \%$ (uma criança) pela contrastada pode residir no fato de ambas valorizarem a cor, aumentarem o contraste, valorizarem os níveis de preto e definirem os limites dos componentes do objeto e das cores. É relevante considerar que a pintura, nessa fase, é caracterizada pelo uso das cores primárias e puras (sem misturas com preto e branco), pelos contornos pretos e pelos fortes limites entre uma cor e outra. 


\section{Preferência da cor}

A visualização da cor, em uma imagem ou cena, corresponde ao primeiro elemento percebido. Como se trata de um processo psicológico torna-se pessoal e mutável: cada indivíduo enxergará uma determinada cor de forma diferenciada.

Dessa forma, a segunda etapa do experimento consistia na opção pela presença ou ausência de cor no referente escolhido. Apenas $16,66 \%$ optou pela ausência de cor conscientemente, muitas alteravam suas escolhas após visualizarem o referente colorido. Podese, nesses casos, afirmar que a opção pelo colorido pode indicar a necessidade de adequar a fotografia ao seu referente, uma vez que o mundo é percebido em cores. O uso do preto e branco, dentro dos conceitos visuais aplicados à imagem, indica aplicação de emoções e poesia à imagem, conceitos complexos para crianças nessa faixa etária.

Considera-se que, se as fotografias indicassem gravuras, desenhos ou imagens não referentes ao real, a escolha pelo colorido envolveria mais fatores. Por exemplo, se a criança gostasse da cor vermelha e lhe fosse apresentada uma imagem de uma bola vermelha, esta seria escolhida pela sua relação emocional com a cor. Já objetos reais representados de formas menos artísticas, como a fotografia, promovem escolhas pautadas na experiência: uma maçã pode ser verde ou vermelha, mas não azul. Dessa forma, Dubois (1993) relaciona a fotografia ao real, portanto considera-se plausível dizer que a preferência pelo colorido, em $75 \%$ das escolhas, deriva da relação referente/fotografia.

\section{Relação da tridimensionalidade}

Ao organizar as escolhas relacionadas ao ângulo de observação e o quanto do objeto se visualiza, buscava-se responder ao 
questionamento: será a criança de dois a três anos capaz de identificar esta imagem mesmo incompleta? Ou será esse processo construído culturalmente e, portanto, dependente da sua experiência social e reforçada com a idade?

Em relação ao ângulo de visualização, a maior parte das respostas acompanhou o processo lógico de visualização de objetos e as teorias visuais: frontal e ocupando todo o quadro da imagem. Contudo, obtiveram-se respostas variadas que, embora centradas no processo lógico, também indicavam a busca de ângulos inusitados. Estimava-se que as respostas seriam condizentes com o tradicionalmente visualizado pela criança em seu dia a dia: pessoas adultas vistas de baixo para cima; objetos pequenos, como a colher, de todos os lado; e animais pequenos de cima para baixo.

Entretanto, 50\% optou pelo ângulo inferior (de baixo para cima) em objetos pequenos e manipuláveis, como a colher, a bola e o gato. Tal dado indica uma preferência mais dinâmica e criativa do ângulo de visualização. Deve-se considerar a possibilidade de tal escolha ter sido influenciada pela pouca altura da criança em relação ao mundo natural: poucas são as coisas (pessoas, objetos e paisagens) não vistas em ângulo inferior. Talvez torne-se, nessa fase, mais natural a busca por esse ângulo. Os referentes gato e Galinha Pintadinha podem ter sido selecionados em sua visualização frontal por conta da perfeita aparência de seus olhos.

As escolhas de ângulos pouco usuais podem ser explicadas pelo despertar de emoções como curiosidade e diversão, dando caráter de brincadeira à imagem.

Em relação ao plano, 33,33\% escolheu o plano geral, um forte indicativo da preferência de percepção pelo objeto em sua representação mais informativa. Assim como as escolhas do plano geral aplicado ao gato e a colher permitem total visualização de seus elementos e proporções. 
Ainda em relação ao plano aplicado, as respostas enquadraram pelo menos $75 \%$ do objeto. A capacidade de completar objetos a partir de partes, ponto observado na etapa sete, é a premissa da Lei de Continuidade da Gestalt, bastante aplicada no universo da fotografia e do Design.

Estimava-se que essa concretização da totalidade da imagem não fosse possível nessa faixa etária. Entretanto, 25\% das respostas indicaram planos mais fechados, representando apenas $30 \%$ do referente. Sendo o plano detalhe indicado para a visualização da Galinha Pintadinha e o primeiro plano aplicado à bola e ao gato. Considera-se a possibilidade de tais escolhas terem sido desenvolvidas com base apenas na valorização dos detalhes de tais referentes.

\section{Percepção da nitidez}

A nitidez de um objeto corresponde a um dos elementos mais importantes para sua visualização. Esse é um dos elementos visuais mais relevantes para as teorias visuais: normalmente é a nitidez que permite a identificação do que está sendo representado. Entretanto, esse elemento é subjetivo e pode apresentar aplicações diferenciadas de acordo com a área visual e a época em que está inserido. Entre as respostas, 58,33\% correspondem a escolhas relacionadas aos graus alto e suficiente de nitidez. Mesmo ruídos na imagem podem representar, para a criança, nitidez suficiente para interpretar qual objeto está representado, 25\% apresentam essa escolha. Três crianças (25\%) efetuaram essa escolha e outras cinco (33,33\%) optaram pela referência padrão da teoria visual: nítido.

Apenas 33,3\% escolheram as imagens totalmente nítidas, contrariando boa parte das orientações das teorias visuais praticadas atualmente. Nos casos de escolha pelo desfoque é necessário considerar que a configuração do referente pode influenciar a 
escolha. Por exemplo, uma bola ainda é uma bola mesmo desfocada. Assim como imagens com grande grau de contraste entre figura/ fundo.

Não houve preferências pelo desfoque seletivo, talvez ocasionado pela pouca diferença entre o nítido, sendo necessárias acuidade visual e percepção dos detalhes bem desenvolvidas. Ou ainda, sua não ocorrência pode ser justificada pela simples falta de interesse.

\section{CONSIDERAÇÕES FINAIS}

Como parte integrante de uma macropesquisa, o presente estudo buscou analisar, partindo de um recorte específico, o grau de influência, ou a validade, das teorias visuais nos processos de percepção visual. Durante o processo de pesquisa, especialmente na análise dos dados, diversas surpresas e informações contrárias às expectativas teóricas estudadas foram apresentadas.

Tal qual a interpretação de um texto, a análise das possibilidades de leitura da linguagem visual deve ser exercitada e compreendida. 0 mundo real, uma fotografia, um vídeo, uma pintura ou uma gravura diferem de um texto apenas pela natureza de suas informações e, embora o indivíduo consuma um maior número de informações visuais, em comparação àquelas textuais, as primeiras pouco são discutidas e exploradas.

Embora a pesquisa desenvolvida tenha sido apresentada de forma resumida neste artigo, foi possível observar que o processo de decisões que levaram à configuração final do experimento e seus elementos foi um empreendimento delicado e minucioso. Cada escolha, fosse do mecanismo de aplicação ou do suporte e da cor usada, foi exaustivamente avaliada e parametrizada pelo objeto de 
investigação, suas características e as especificidades da população amostra.

Embora a filosofia de Dondis (1997) aponte para um alfabetismo visual e apresente passos para o seu exercício, e tenha sido parte constante da base teórica, a prática revela outros direcionamentos. O experimento desenvolvido nesta pesquisa revelou uma hipótese não apresentada por Dondis: o processo de percepção da linguagem visual é muito mais elaborada que a simples segregação de elementos, é um processo complexo e dependente do contexto cultural em que o receptor está inserido.

A influência do meio social nos processos psicológicos da criança mostrou-se imediata e, muitas vezes, determinante da sua abrangência. A experiência, nesse caso relacionada à idade, também representou um forte modificador da capacidade perceptiva da criança: a experiência e o amadurecimento biológico permitiram conexões e reflexões mais profundas.

A percepção, como processo, permanece particular e complexo. Contrariando Dondis (1997), foi possível observar que ainda não é possível estabelecer um processo de leitura e compreensão das imagens voltadas a sua produção pautada na redução de imagens a conjuntos de elementos destituídos de contexto.

Por meio do trajeto traçado durante o processo de pesquisa foi possível perceber, dentro do grupo estudado, que aspectos culturais influenciam diretamente a percepção do indivíduo e não obrigatoriamente as teorias visuais serão observadas nas preferências visuais. Fatores como personalidade e experiência de vida têm relação com os processos perceptivos, atuando na visualidade. Neste sentido, Arnheim (2013) apresenta um discurso mais conciso e válido ao contexto atual, enquanto Dondis (1997) apresenta ideias insuficientes às produções imagéticas contemporâneas. 
O processo de Vygotsky (2010) acerca da formação do indivíduo por meio da cultura e das inter-relações sociais tem se mostrado bastante eficaz enquanto mecanismo de avaliação do comportamento e dos processos inteligíveis do indivíduo. Sua teoria visionária sobre a cultura como elemento transformador e das adaptações particulares dos inputs externos foi decisiva nos processos de análise e interpretação das escolhas perceptíveis da população.

Como passos futuros para esta pesquisa, sente-se a necessidade, após a conclusão do processo, da repetição do experimento com outros indivíduos com diferentes graus de aproximação com as teorias visuais a fim de obter mais parâmetros de análise dessas influências.

Compreender a linguagem visual e os processos cognitivos significam, primeiramente, compreender mais sobre o indivíduo e sobre o macrocontexto em que este encontra-se inserido. São suas experiências, conhecimentos adquiridos e reflexões sobre o mundo os grandes formadores dos processos inteligíveis e das inter-relações sociais. 


\section{REFERÊNCIAS}

ACAUAN, E. M. O.; PERSICHETTI, S. A estética de Sebastião Salgado. 2010. Trabalho de conclusão de curso (Especialização em Fotografia) - Universidade Estadual de Londrina, Londrina, 2010.

ACAUAN, E. M. O. SOBRAL, João E. C. As percepções do olhar: uma análise da linguagem fotográfica em crianças. 2015. Dissertação (Mestrado em Design) - Univille, Joinville, 2015.

ARNHEIM, R. Arte e percepção visual: uma psicologia da visão criadora. Trad. Ivonne Terezinha de Faria. São Paulo: Pioneira Thomson Learning, 2013.

BORGES, M. E. L. História \& fotografia. Autêntica, 2013.

CASTORINA, J. A. $O$ debate Piaget-Vygotsky: a busca de um critério para sua avaliação. São Paulo: Ática, 2008.

COSTA, J. El linguaje fotográfico. Madrid: Ibérico Europeia, 1977.

DONDIS, D. Sintaxe da Linguagem Visual. Trad. Jefferson Luiz Camargo. 2. ed. São Paulo: Martins Fontes, 1997.

DUBOIS, P. $\mathbf{O}$ ato fotográfico e outros ensaios. Campinas: Papirus Editora, 1993.

GIL, A. C. Como elaborar projetos de pesquisa. 5. ed. São Paulo: Atlas, 2010.

KRAUSS, R. $O$ fotográfico. Trad. Anne Marie Davée. 2. ed. Barcelona: Gustavo Gili, 2002.

PIAGET, J. Éstudes Socologiques. Genéve: Droz, 1965. 
ROUILLÉ, A. A fotografia: entre documento e arte contemporânea. Trad. Constancia Egrejas. São Paulo: Senac São Paulo, 2009.

SACKS, O. W. O homem que confundiu sua mulher com um chapéu e outras histórias clínicas. São Paulo: Companhia das Letras, 2005. SONTAG, Susan. Diante da dor dos outros. São Paulo: Companhia das Letras, 2003.

TAILLE, Y. OLIVEIRA, M. K.; DANTAS, H. Piaget, Vygotsky, Wallon: teorias psicogenéticas em discussão. São Paulo: Summus Editorial, 1992.

VYGOTSKY, L. S. Formação social da mente. Trad. José Cipolla Neto; Luis Silveira Menna Barreto; Solange Castro Afeche. 4. ed. São Paulo: Martins Fontes, 2010.

. Pensamento e linguagem. São Paulo: Martins Fontes, 1998. 